\title{
B.B.C. LIEMARAS
}

\section{TIMBER OWNERSHIP and LUMBER PRODUCTION in the INLAND EMPIRE}

\section{DAVID TOWNSEND MASON}

Chief, Timber Section, Bureau of Internal Revenue Professor of Forestry. . . University of California Formerly Assistant District Forester, Forest Service

\section{Prepared as Part $V$}

OF A SERIES OF STUDIES OF THE LUMBER INDUSTRY, MADE BY THE FOREST SERVICE OF THE UNITED STATES DEPARTMENT OF AGRICULTURE

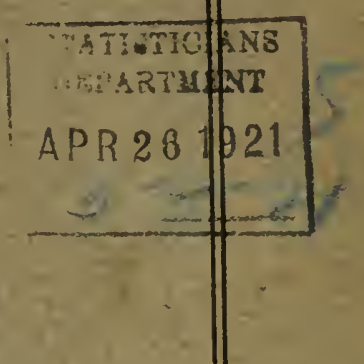




$$
=1+x+1+x
$$




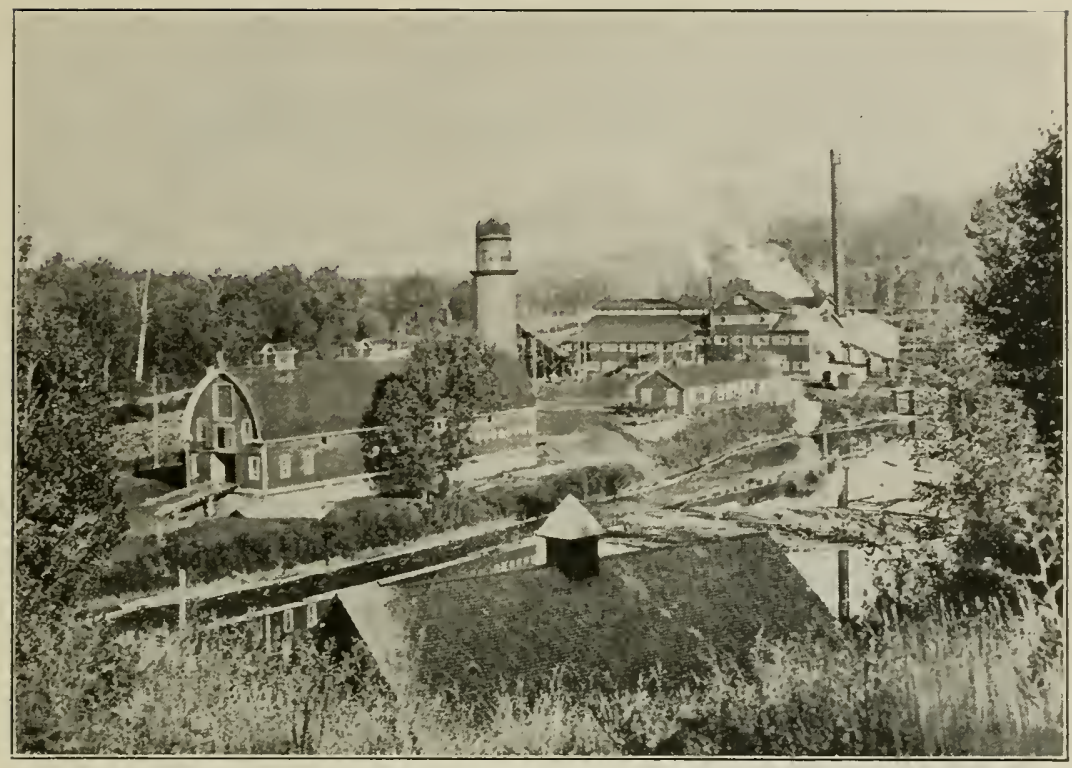

An Inland Empire Sawmill Plant

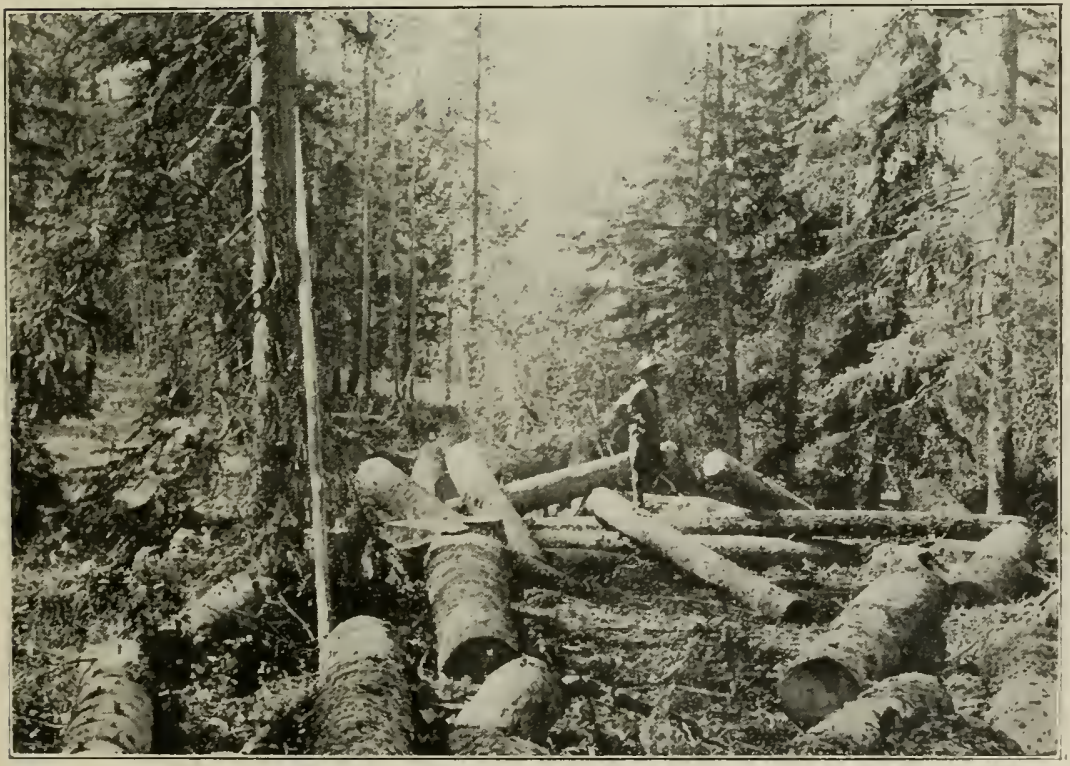

LOGgING IN THE INLAND EMPIRE 


\section{FOREWORD}

THE following Report is published by the Western Pine 1 Manufacturers' Association, as the association believes it constitutes a valuable eontribution to a better understanding of the lumber industry. The mills that were eovered by the field work were almost without exception members of this association and the bulk of its membership was covered.consequently it is believed that the study accurately reflects the condition of the industry represented by the association at the time it was made.

It is recognized that some of the conditions have been altered by the war and by natural developments and ehanges in the industry itself, but the basic facts contained in the following study not only constitute a valuable record, but are in many instances of permanent value to anyone seeking a knowledge of the fundamental principles under which the industry operates.

This Association regards this work as the most thorough and comprehensive economic study ever made of any section of the lumber industry.

WESTERN PINE MANUFACTURERS' ASSN. 


\title{
TIMBER OWNERSHIP and LUMBER PRODUCTION in the INLAND EMPIRE
}

BY

\section{DAVID TOWNSEND MASON}

Chief, Timber Section, Bureau of Internal Revenue

Professor of Forestry . . . University of California

Formerly Assistant District Forester, Forest Service

\section{Prepared as Part $V$}

OF A SERIES OF STUDIES OF THE LUMBER INDUSTRY, MADE BY THE FOREST SERVICE OF THE UNITED STATES

DEPARTMENT OF AGRICULTURE

\author{
s \\ Price 50 cents \\ PUBLISHED BY
}

THE WESTERN PINE MANUFACTURERS ASSOCIATION of PORTLAND, OREGON 


\section{FEDERAL TRADE COMMISSION.}

The Forester,

Washington, May 29, $191 \%$.

U. S. Department of Agriculture,

Forest Service, Washington, D. C.

DEAR Sir: At the request of the Forest Service the Federal Trade Commission has examined the report of the Forest Service on Timber Ownership and Lumber Production in the Inland Empire and recommends its publication.

The statistics and other facts in this report have been for the most part collected by the Forest Service, but the record of the hearings of this Commission regarding conditions in the lumber industry, and other data in its possession regarding the organization of the industry, have been placed at the disposal of the Forest Service under the plan of cooperation which has been adopted by the Forest Service, the Bureau of Foreign and Domestic Commerce and the Federal Trade Commission.

With the conclusions reached by the Forest Service with respect to conditions in the Inland Empire in the production and distribution of lumber, and with the suggestion in the public interest of remedy therefor, the Federal Trade Commission is in general agreement. For the particular statements of fact, however, and the method of their presentation the Federal Trade Commission assumes no responsibility. Nor, with respect to matters peculiar to its jurisdiction, does the Commission consider itself limited to the conclusions reached by the Forest Service.

By order of the Commission.

(Signed) L. L. Brackex, Secretary. 


\section{CONTENTS}

Introduction. Page

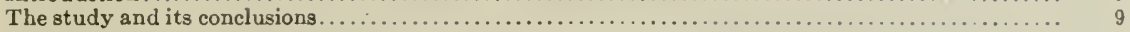

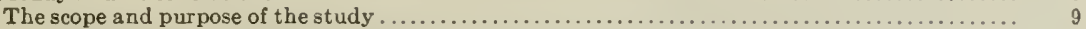

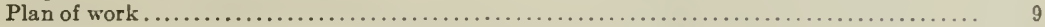

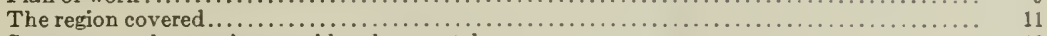

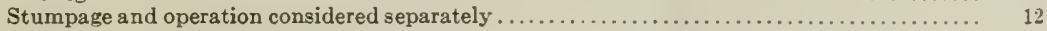

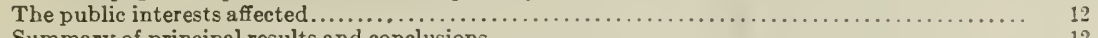

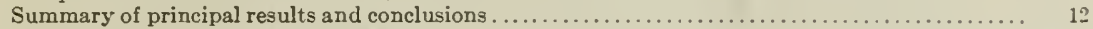

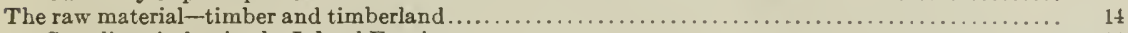

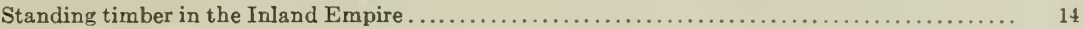

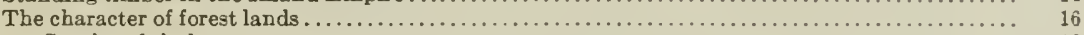

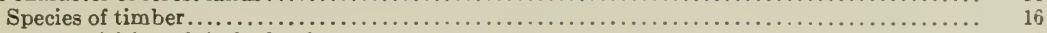

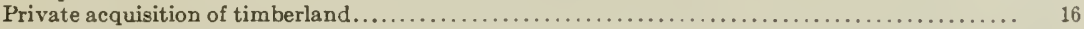

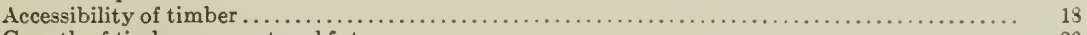

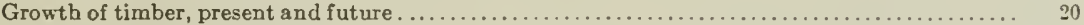

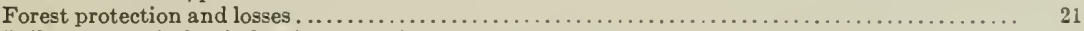

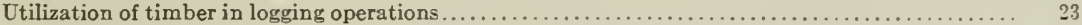

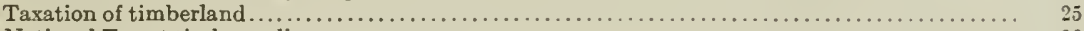

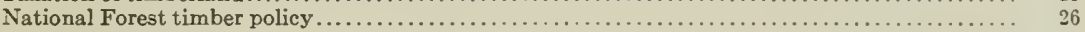

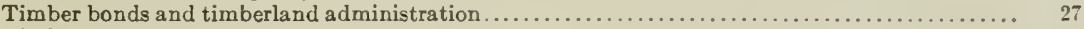

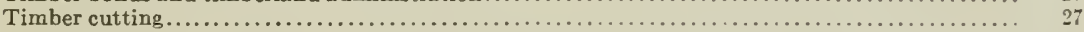

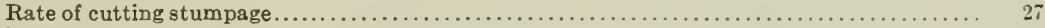

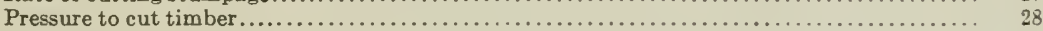

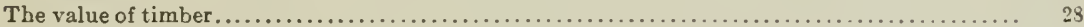

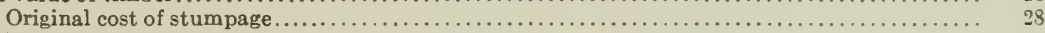

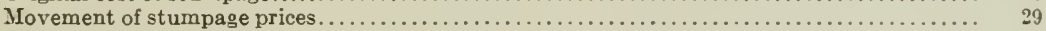

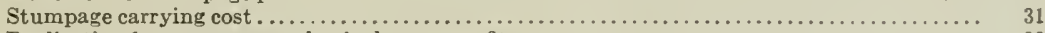

Realization from stumpage; book charge; profits.............................. 33

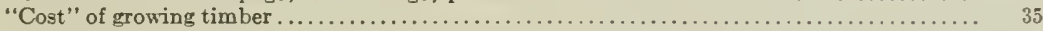

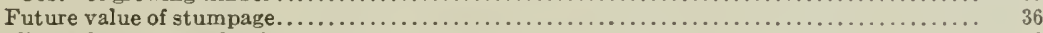

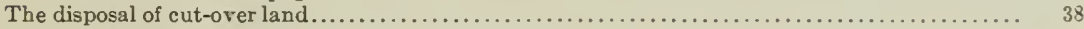

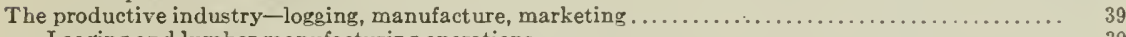

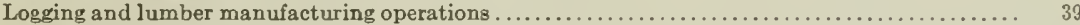

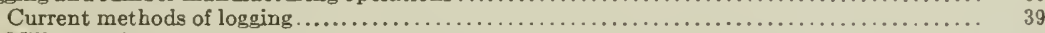

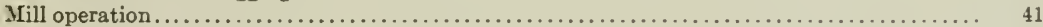

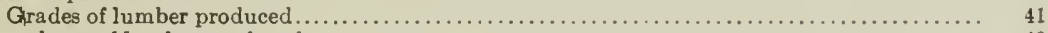

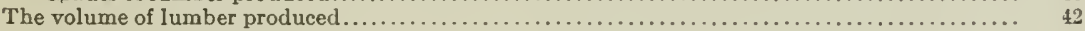

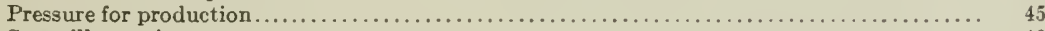

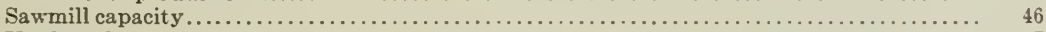

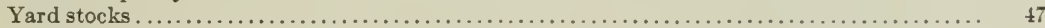

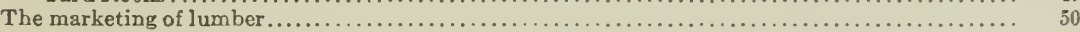

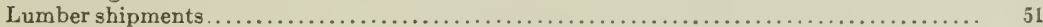

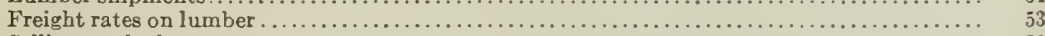

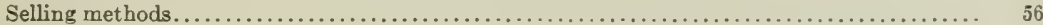

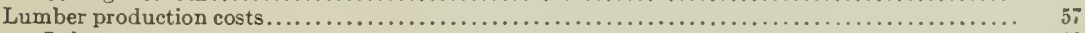

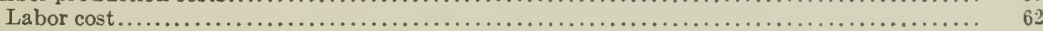

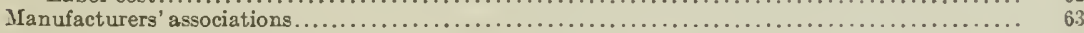

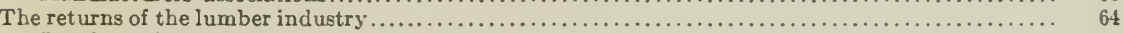

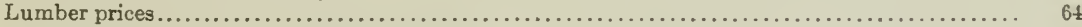

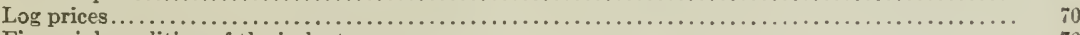

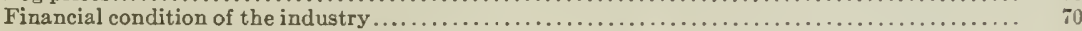

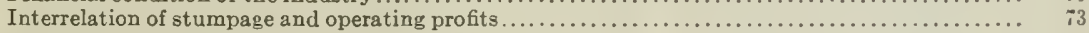

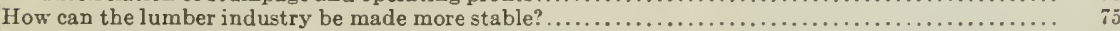

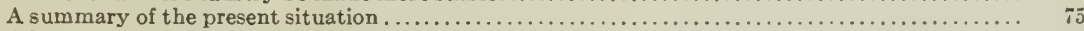

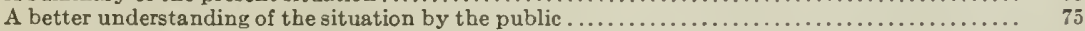

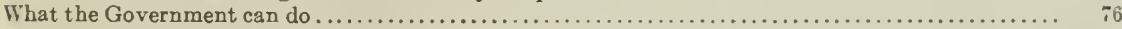

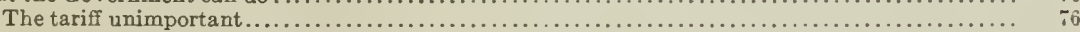

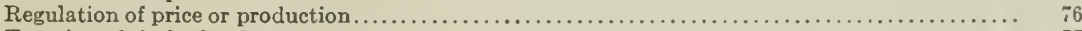

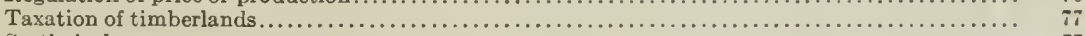

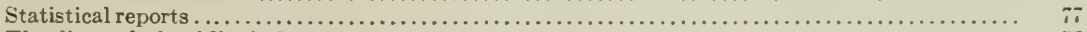

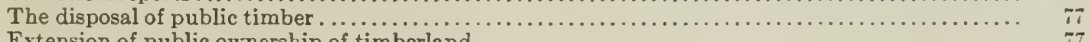

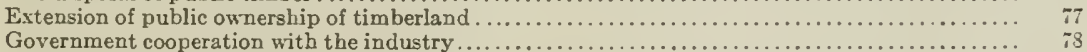

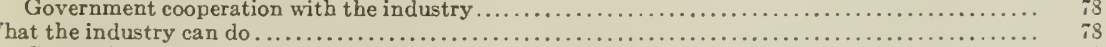

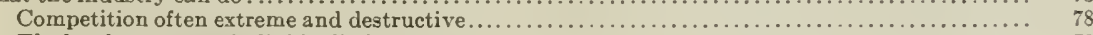

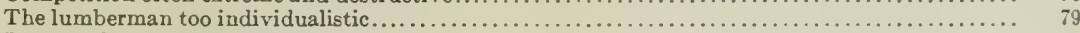

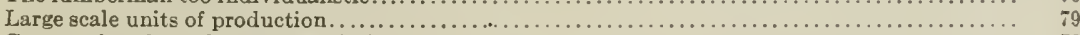

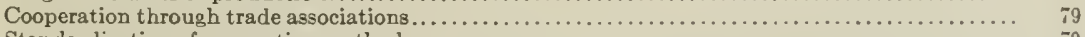

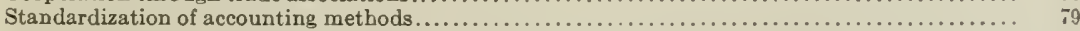

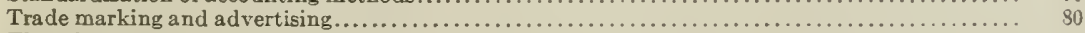

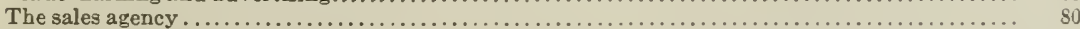

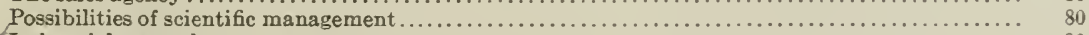

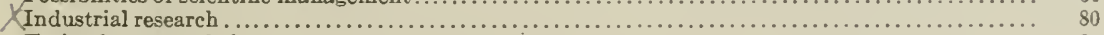

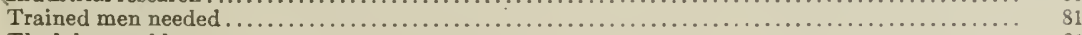

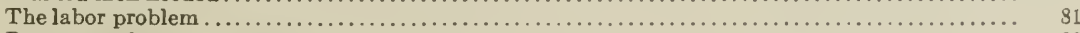

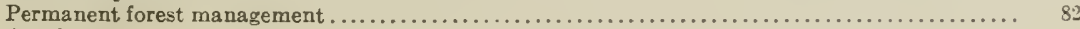

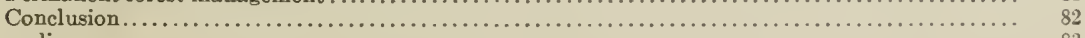

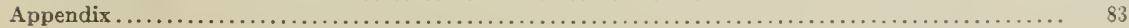




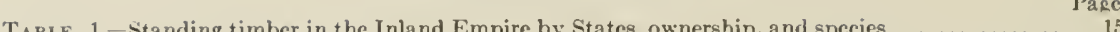

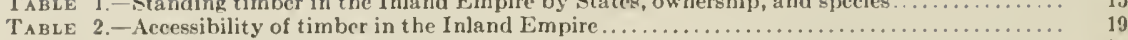

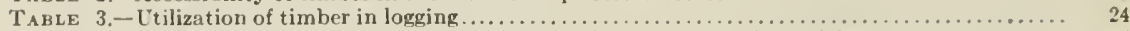

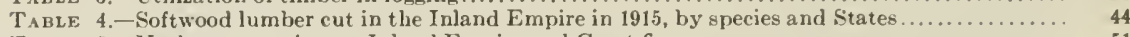

TABLE 5.-Market comparisons-Inland Empire and Coast fir ............................. 51

TABLE 6.-Inland Empire costs, 1905 to 1914, inclusive-Logging, lumber manuiacturing and selling. 58

TABLE 7.- Haximum, minimum, and average costs of various divisions of lumber production at

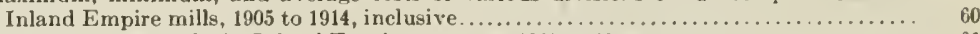

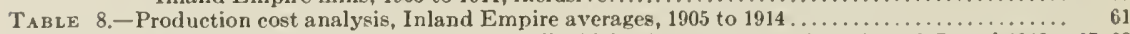

TABZE 9.-Selling price of lumber per thousand, all widths, for $1913,1914,1915,1916,1917$, and $1918 \ldots 67,68$

TABLE 10.-Financial statisties of lumber companies in the Inland Empire ..................

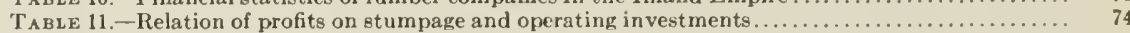

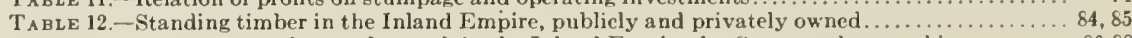

TABLE 13.-Forest area and annual growth in the Inland Empire, by States and ownership ........... 86-88

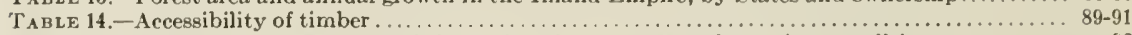

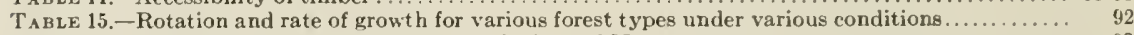

TABLE 16.-Cost of fire protection in northern Idaho and Montana . . . . . . . . . . . . . . . . . . . .

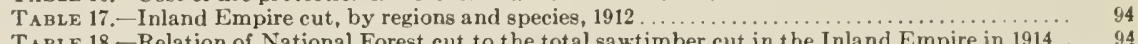

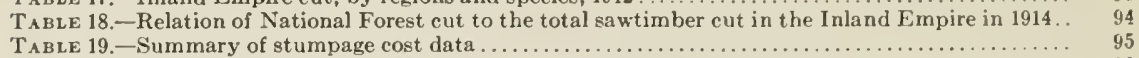

TABLE $19 .-$ Summary of stumpage cost data $\ldots \ldots \ldots \ldots \ldots \ldots \ldots \ldots \ldots \ldots \ldots \ldots \ldots \ldots \ldots \ldots \ldots \ldots \ldots \ldots \ldots \ldots \ldots \ldots \ldots \ldots \ldots \ldots$
TABLE $20 .-$ Cost of growing timber, computed at compound interest $\ldots \ldots \ldots \ldots \ldots \ldots \ldots \ldots$

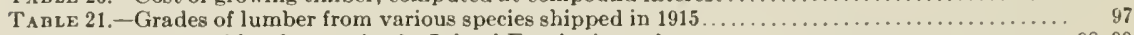

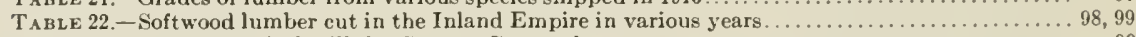

TABLE 23.-Cut of identical mills by States-Census data . . . . . . . . . . . . . . . . . . . . . . . 99

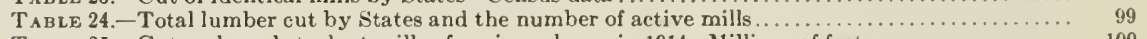

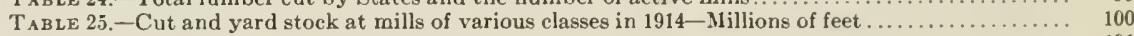

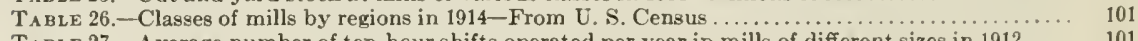

TABLE 27. - A verage number of ten-hour shifts operated per year in mills of different sizes in $1912 \ldots \ldots .101$

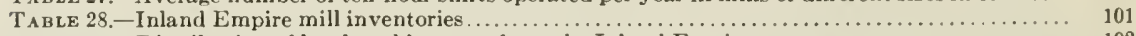

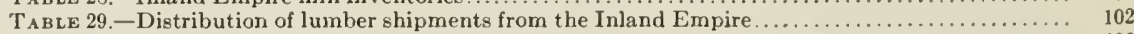

TABLE 29a.-Comparative shipments of Inland Empire lumber to various regions .................... 102

TABLE 30.-Average mill values of lumber and freight thereon to each State consuming Inland Empire products...

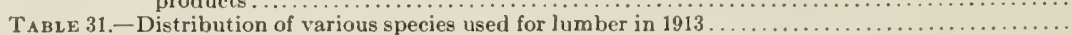

TABLE 32.-Number of men employed in the lumber industry in the Inland Empire in $1909 \ldots \ldots \ldots$.

TABle 33.-Log markets of the Inland Empire. Prices of logs per thousand feet, log seale...........

Fig. 1,-The Inland Empire and its timber regions.

Fig. 2.-Stumpage prices and volume of timber sold by private owners, the State of Idaho, and the U. S. Forest Service.

FIG. 3.-Relation of "going price" of stumpage to a verage annual outlay and average annual outlay

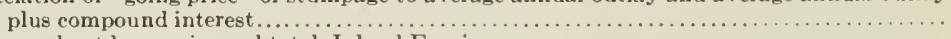

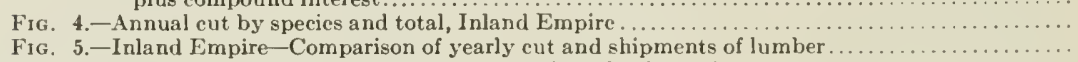

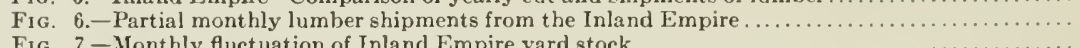

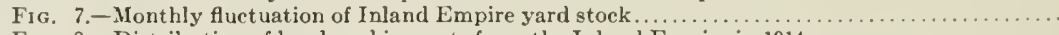

Fig. 8.-Distribution of lumber shipments from the Inland Empire in $1914 \ldots \ldots \ldots \ldots \ldots \ldots \ldots \ldots \ldots \ldots \ldots \ldots \ldots \ldots \ldots \ldots \ldots \ldots \ldots \ldots \ldots \ldots \ldots \ldots \ldots \ldots \ldots \ldots \ldots \ldots$
Fig, 9.-Lumber freight rates, N. P. Ry., June $1915 \ldots \ldots \ldots \ldots \ldots \ldots \ldots$

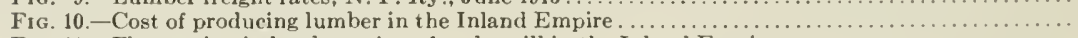

F1g. 11.-Fluctuation in lumber prices, f. o. b. mill in the Inland Empire.

F1g. 11a. - Fluctuation of a verage mill run lumber prices on important species f. o. b. mill in the Inland Empire.....

Fig. 12.-Composite curves showing fluctuation of lumber prices in the Inland Empire compared with other commodities

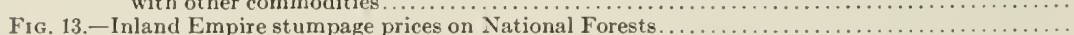

F1G. 14.-Illustrating "cost" of carrying stumpage under different conditions if compound interest is includled...

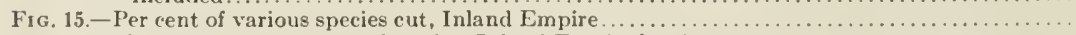

Fig. 16.-Fluctuation in charge for board at Inland Empire logging camps.

Fluctuation in wages for certain occupations at Inland Empire logging camps and sawmills .

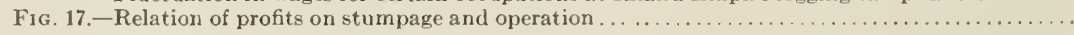




\title{
TIMBER OWNERSHIP AND LUMBER PRODUCTION IN THE INLAND EMPIRE.
}

\author{
By David Townsend Mason
}

\section{INTRODUCTION. ${ }^{1}$}

The following study of the lumber industry in the Inland Empire was made in 1915. Since it was impracticable to publish the report immediately after it was completed this introduction is added to call attention briefly to some of the more important occurrences since the study was made.

In 1915 the industry in this region, as was also the case in nearly all of the other large lumber producing sections of the United States, was experiencing a serious depression. The causes of the situation as it then existed are set forth in the body of the report. The conditions and tendencies of that time presented many serious problems to the industry, and in addition threatened the interests of the American public owing to the economic impracticability of husbanding timber resources wisely with due regard for future needs.

The lumber industry in the Inland Empire presents a totally different picture in 1920. Many factors have led to an enormous excess of demand over the available supply of lumber unparalleled in the previous history of the industry. A great rise in lumber prices has resulted from the frenzied bidding of lumber buyers. The main problems of 1915 do not harass the lumber manufacturer today. The high tide of lumber prices has largely removed his financial difficulties. The overload of stumpage with its carrying charges is no longer a nightmare. His concern is rather to manufacture and sell in the present favorable market all of the lumber which his organization can produce, and obtain the cars to deliver.

Timber values have increased materially, especially during the past year. One now hears of sales of timber in which white pine brings a price sometimes exceeding $\$ 10.00$ per thousand feet, western pine prices as high as $\$ 6.00$ per thousand feet, an increase of perhaps 50 per cent over 1915 values. The higher prices just mentioned ordinarily apply to timber purchased for immediate cutting. Stumpage values have now possibly reached an average of $\$ 2.25$ per thousand feet; in other words they perhaps have caught up with the original outlay plus six per cent compound interest indicated in figure 3.

The period since 1915 has been much like the period immediately preceding that year in that there has been no marked tendency on the part of the larger owners to acquire timber. In the case of ten owners, each holding not less than 250 million feet of timber in Idaho both at the beginning of 1913 and at the end of 1918 , it is found that they had an aggregate of 16 billion feet of timber at the beginning of the period. During the period they cut 10 per cent of this quantity, and they added to their reserves approximately 5 per cent, so that at the end of the period the ownership included 95 per cent of the quantity on hand at the beginning of the period. These owners could easily have acquired far more than the 5 per cent indicated if they had been inclined to do so.

In 1915 timber owners were not in the least interested in managing their properties with the object of the permanent production of forest crops. Today the timber owner is inclined to study the situation more carefully to see if possibly it may not be profitable to grow timber as a permanent business. The greatly increased price

1This introduction was written in June, 1920. 
of forest products and the knowledge that the country will in the immediate future require from the Inland Empire a larger portion of its timber supply than it has in the past, has brought about some change in sentiment.

The utilization of the timber cut in the woods has become closer. It is now considered profitable to cut smaller trees, to remove logs of smaller diameter and logs of a greater per cent of defect than was the practice in 1915. In some cases logs as small as 4 inches top diameter are now utilized.

The rate of cutting standing timber has not increased materially since 1915. It is probable that the decreasing lumber cut in the South will give the Inland Empire an opportunity to increase its cut materially during the next ten years.

In 1915 there was a strong desire on the part of many timberland owners to liquidate their holdings owing to the great burden of carrying costs. Owing to the profitable state of the industry carrying costs are not troublesome at present. There is now a strong desire to cut as much lumber as possible to take advantage of exceptionally high prices. The labor situation, mentioned later, is one factor preventing the cutting of as much lumber as manufacturers would like to produce.

Since 1915, costs of production have increased greatly. It has been difficult to secure labor. Working hours have been rather generally reduced from ten to eight hours per day. Wages have been greatly increased. Wood sawyers, for example. received a wage of approximately $271 / 2$ cents per hour in 1913 ; in 1919 the wage was about $621 / 2$ cents per hour, or an increase of 127 per cent. Similar increases have been made in other phases of woods work and in mill work. In an endeavor to secure and hold better labor, substantial improvement has been made in the conditions under which the labor of the lumber industry lives. Another cause of the rise in production costs is found in the great increase in the cost of supplies and in the difficulty with which supplies such as saw mill machinery and heavy logging equipment are secured.

Lumber prices have risen rather steadily since 1915, reaching early in 1920 the highest prices known in general lumber markets in the United States. A report dated April 15, 1920, from the District Forester at Missoula, Montana, addressed to the Forester in Washington (from which among other sources is drawn part of the information given in this introduction) makes the following statement:

"The present high cost of forest products (to consumers) is not due to the depletion of forest resources in this region. The long freight haul, high wages, poor class of labor, number of hours of effective time per day, difficult logging chances, shortage of stock on hand, and skyrocket bidding for lumber are the main factors affecting the present prices."

Undoubtedly the most important of the factors just mentioned is the fact that the buyers of lumber have been bidding wildly, one against another, to obtain such lumber as has been available, for their bidding has carried lumber prices to a point where they bear no reasonable relation to the greatly increased cost of production caused by the other factors mentioned.

The market in which Inland Empire lumber is sold has shifted somewhat since 1914. In 1919 about twice as much lumber was sold east of the Mississippi River as in 1914. To Table 29 in the Appendix there is appended a supplementary table (29. $)$ comparing the shipments in 1911, 1914, 1917 and 1919. As a result of building restrictions and of the great demand for munition and supply containers dereloped during the war the proportion of lumber used west of the Mississippi River decreased substantially. A reason for the continuation of this situation in 1919 is found in the three successive drouth years in eastern Montana which have reduced the farmers of this region to the point where little construction has been under way. If a good crop is obtained in Montana in 1920 the demand for lumber in this territory will probably be greatly increased.

In reading this report it should be kept clearly in mind that the data presented and the conclusions drawn are based upon the conditions existing in 1915 and prior 
thereto. The greatly increased profits obtained by lumber manufacturers in 1918 and 1919 furnish in certain respects a new outlook on the situation discussed in the body of the report. Material profits have tended to stabilize the lumber industry in the Inland Empire as in other parts of the West through strengthening the financial backbone of the industry and affording opportunity for the reduction of indebtedness. Some of the capital obtained through the liquidation of timber resources in the East and South is being reinvested in forest enterprises in the West, which to some extent has a stabilizing influence through the introduction into the West of more strongly financed timber owners. Nevertheless certain of the fundamental problems evident in 1915 have not disappeared. They have rather been lost sight of in the present favorable market situation which is likely to prove more or less temporary in duration. It is well for lumber manufacturers and timber owners to recall the conditions which confronted them in 1915 and not lose the benefit of the lessons then learned. An opportunity is now afforded to utilize this period of prosperity in such ways as will give the industry greater permanent stability and prevent a repetition of the more distressing of the conditions formerly obtaining. A period of prosperity may dangerously tend to increase production, to extend credit, to reach out in new developments which may not be soundly financed and which might lead to a depression similar to that of five years ago.

In general it has not been attempted to carry this report beyond the period which it originally covered. It has been possible, however, to extend some of the tables where the data for later years were found readily available. It is feared that in the hasty revision of the report in the light of later events it may not read as clearly as it should, since in a few places statements have been introduced to indicate occurrences since 1915. These, no doubt, will be self-evident. In general the report presents the situation as it appeared in 1915.

\section{THE STUDY AND ITS CONGLUSIONS.}

THE SCOPE AND PURPOSE OF THE STUDY

The study of the lumber industry in the Inland Empire was undertaken as part of a comprehensive investigation including timber ownership and lumber manufacture in the main lumber producing regions, the principal lumber markets of the United States, the foreign lumber markets, the replacement of lumber by substitutes, the utilization of low grade lumber and mill waste, and the adaptation of lumber manufacture and grading to the requirements of consumers. It was the purpose of the investigation to determine the fundamental economic facts in the situation, their effect upon forest conservation, and their bearing upon public policies in relation to forest land. The study was conducted by the Forest Service of the United States Department of Agriculture in co-operation with the Bureau of Corporations, the Federal Trade Commission, and the Bureau of Foreign and Domestic Commerce.

PLAN OF WORK.

The study of timberland ownership and lumber manufacture in the Inland Empire was made in 1914 and 1915 by the author, with the assistance of Donald Bruce, Stephen Malven, Joseph Kittredge, Emanuel Fritz, and Roscoe Haines, all members of the Forest Service.

Data on the lumber industry in the Inland Empire were gathered from practically all available sources of information, including the records of the Forest Service, the Bureau of Corporations, and other Federal Bureaus, the States, the counties, the Western Pine Manufacturers' Association, the Montana Larch and Pine Manufacturers' Association, and individual lumber manufacturing and timber owning companies. Thirty-nine of the leading companies in the Inland Empire were asked to permit the gathering of data directly from their books. These companies represented an annual cut of approximately 1,100,000,000 feet out of a total of approximately $1,600,000,000$ feet in the entire region. Thirty-three of these companies consented to open their records to representatives of the Forest Service. These firms cut approximately 86 per cent of the lumber cut by all 39 companies, and about 60 per cent of the entire cut of the Inland Empire. Their records go back over 25 years in some cases and represent altogether nearly 300 mill years-counting each year's operation of each company as one. Not all of the available records were examined, however, for especially in the earlier years the records could not be under- 


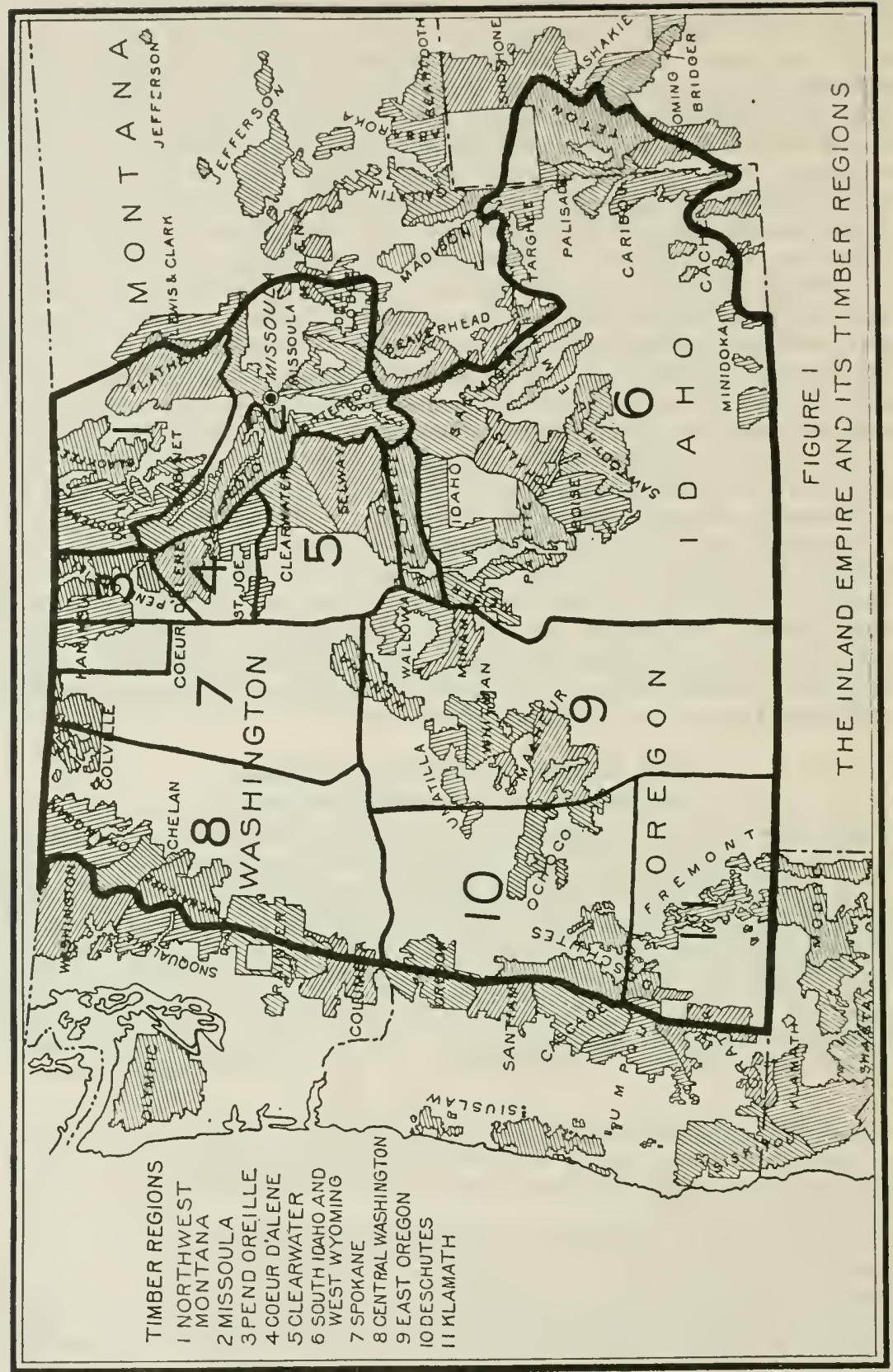

stood without considerable interpretation, and usually, owing to changes in personnel, lapses of memory, etc., there was no one to do the interpreting. Altogether, the records of about 200 mill years were examined; and of these about 150 were in condition to be analyzed and used in certain of the tables given in this report.

A sufficient general discussion was held with 42 persons of importance in the lumber business in the region to get thoroughly at the general situation as it appeared to these men. 
The Inland Empire as generally known has somewhat indefinite boundaries. It is usually thought of as a part of northern Idaho, eastern Washington, and eastern Oregon. For the purposes of this study, however, the boundaries were drawn as indicated on figure 1, thus including the watershed of the Columbia River east of the Cascade Mountains and a little additional territory. The Rocky Mountains and their outlying ranges cover the eastern portion of the territory, in Wyoming, western Montana, northern and central Idaho, and a small corner of northeastern Washington. The east slope of the Cascade Mountains forms the western edge of the Inland Empire. The Blue Mountains of northeastern Oregon and southeastern Washington are separated somewhat from the main Rockies, and even more definitely from the Cascades. These mountain ranges, together with the foothill country lying at their bases and portions of the plateaus of central Washington and Oregon, support the forests of the Inland Empire.

The total area of the Inland Empire is about 143,000,000 acres, equivalent to that of the New England States, the Niddle Atlantic States, and Virginia. About 55 million acres, or 38 per cent, is classified as forest land, although part of this is barren, owing to its location above timber line. The population of the Inland Empire, about $1,100,000$ persons, will doubtless be greatly increased in the future, but probably will never become as dense as in the manufacturing regions of the east. Water power is abundant for manufacture, but iron and coal are not found in large quantities. The principal activities of the lnland Empire are agriculture, mining, grazing, and lumber production. There are large areas of agricultural lands. The Butte and Coeur d'Alene mining regions are famous producers of copper and lead respectively. Although large areas formerly devoted to grazing are now more intensively used for agricultural crops, grazing is still of great importance; and much of the land is more valuable for grazing than for any other purpose. The lumber industry engages the services of about 14,000 men, and has an annual payroll of about $\$ 14,000,000$. It is a business which will increase in importance.

The Inland Empire was first explored by Lewis and Clark about 1805. Although Roman Catholic missionaries had been in the territory for a number of years, the whites really took possession of the country only in the fifties, when they came to engage principally in placer mining for gold. Placer mining later gave way to deep mining for silver, copper, and lead, and at the same time the stock industry developed in importance. Agriculture, and last of all lumbering, became important after the coming of the railways.

The principal features of the transportation system of the region are the Northern Pacific Railway, which was completed in 1883; the Oregon-Washington Railroad and Navigation Company, completed in 1884; the Great Northern Railway, completed in 1893, and the Chicago, Milwaukee and St. Paul Railway, completed in 1909. These four transcontinental carriers are fed by numerous branch lines. The lumber industry, to a greater degree than any other industry, has been responsible for their construction. It has brought about the building of several branch lines, such as the Sumpter Valley Railroad in eastern Oregon, the Idaho and Washington Northern in the region to the northeast of Spokane, and the Washington, Idaho and Montana Railroad in the Palouse District of northern Idaho. These railways furnish competitive shipping facilities for most of the lumber of the region, although a number of the mills can ship over but one line.

There is no water transportation from this region, except down the Snake and Columbia Rivers from Lewiston at the western edge of Idaho. At present no lumber is produced at this point, so that all of the Inland Empire product is shipped by rail. It may be found feasible ultimately to ship lumber to points on the Snake River and thence by water to the mouth of the Columbia, where it could be reloaded into seagoing vessels. Many large streams are used to float logs to the mills, especially in the eastern part of the Inland Empire.

The first settlers found the Inland Empire forests occupying only a little more area than at present. The forests were called upon to supply material needed in the early mining activities, and up to the present time mining has required a large and increasing amount of timber. The live-stock industry required only a little timber for fencing, houses, barns, etc. The construction of the railways consumed considerable amounts for ties and trestles. Agricultural development, which responded to the coming of the railways, increased the amount of timber needed for local uses.

It was not until about the beginning of the present century that the lumber industry of the Inland Empire began to do more than supply local demands. About that time a number of Lake States lumbermen came to the region with the purpose of producing lumber for shipment in considerable quantities to Mississippi Valley and Eastern markets. Nearly all of the present operators in the region came from 
the Lake States. They have developed a business which now markets most of its products east of the Rockies. While the lumber industry was called into existence by the local needs of mining, railway, and agricultural interests, it has outgrown the mere supplying of these demands, and has expanded until no small part of the railway, agricultural, and eommercial interests of the Inland Empire are now dependent upon it.

For convenience in discussion, the Inland Empire is divided into several regions within each of which general conditions are similar. 'T'hese regions are outlined in figure 1 .

STUMPAGE AND OLERATION CONSIDERED SEPARATELY.

The stumpage phase of the lumber inclustry is most easily understood if discussed separately from the manufacture of lumber. The stumpage phase includes the acquisition, protection, and holding of timberland to the point where the manufacturing part of the business is ready to use this raw material. The best organized and largest lumber companies usually handle stumpage separately from operation, and for this purpose have separate accounts, administrative organizations, etc. The general subject of stumpage includes, then, the original cost of timberland, methods of financing timber purchases, timberland taxes, interest on borrowed money, protection of timber from fire, insects, and trespass, and the administration of timberland, including the handling of rights of way and minor uses such as grazing, camping, etc. 'The operating phase of the industry, which secures its stumpage for immediate use by direct purchase (or by credit to the stumpage account if the operating company is the owner of the timber cut), includes the various processes of logging, milling, and selling the product.

Another reason for making this separation is the great diversity in stumpage ownership among various timber owning and operating companies. Some own large quantities of stumpage and do not operate; others own some stumpage and conduct large operations; others own very little stumpage and operate on a considerable scale; and still others conduct sawmills but own no stumpage at all. In order to study the industry fairly, these discrepancies must be eliminated by a separate consideration of its two phases.

\section{THE PUBLIC INTERESTS AFFECTED}

The people of the United States as a whole, and especially the people of the Inland Empire, have a vital interest in the proper management of timberland and in the stability of the lumber industry. Although the aggregate quantity of standing timber is large, all of it is going to be needed by the country in the long run. With the huge expansion of population in the United States which is still to come, with the increasing number and variety of products derived from forests, the people of the United States will need all the organic material that can be produced on their farms, from their mines, and in their forests to use for food, clothing, shelter, fuel, and the innumerable articles required by a civilized people. The forest is one of the most important sources of organic material, and it must be managed not as a mine to be abandoned when exhausted, but in such a way as to produce continuous crops. Over one-fourth of the area of the Inland Empire is better suited to growing timber than for any other purpose.

The continued prosperity of the Inland Empire as a whole depends in no small degree upon the stability of the lumber industry. Many people are employed directly by this industry, many others provide supplies of various kinds needed by it, and many more are engaged in transporting and marketing its products. It puts into circulation great sums of money each year for labor, supplies, and freight. It pays a considerable share of the taxes.

Those who use water for domestic supplies, irrigation, power development, and navigation, are interested in the maintenance of forests on the watersheds on which they are dependent. Recreation is recognized as a prime necessity to any people. Forests must be maintained and administered with this in view as one of the important uses. It is entirely practicable to manage the forest so that it will produce maximum crops of wood continuously, do its full duty in watershed protection, and at the same time serve as a splendid playground.

\section{SUMMARY OF PRINCIPAL RESULTS AND CONCLUSIONS}

Of the 143 million acres in the Inland Empire, 55 million, or about 38 per cent, lie in the main forest belt. Of this amount, however, $61 / 2$ million acres lying above timber line or scattered through the timberland are barren or suited only to grazing; 8 million acres are alpine forest which will not produce merchantable timber but are of great importance in protecting streamflow; and 4 million acres will be more valuable when the merchantable timber is cut if used for agriculture than if maintained as forest producing land. The remaining $36 \frac{1}{2}$ million aeres are best suited to the 
permanent production of forest crops. Of this land there is estimated to be 277 billion board feet of merchantable timber, or 10 per cent of the standing timber in the United States. Thirty-three per cent of the timber and 16 per cent of the land are privately owned.

The privately owned timber, which consists of the heaviest and most accessible stands, was acquired principally between 1898 and 1907, at an average price of 77 cents per thousand feet. Standing timber rose rapidly in price from 1900 to 1907, reaching an average of about $\$ 2$ per thousand feet. The price fluctuated very little from 1907 to 1914 , but since then has perhaps fallen off slightly.

Private investments in standing timber are in many cases proving a serious financial problem, owing to the heavy current charges and the considerable period during which they must often be held before cutting is possible. For this reason it appears unlikely that standing timber will increase greatly in value for some time to come.

Inland Empire forests have suffered severely from fire in the past. No serious efforts at protection were made before 1905, when the Forest Service took charge of the National Forests. Since 1906 private owners, through organized protective associations, have greatly reduced fire losses on their lands. Thorough fire protection is a matter of the first importance in forest management, not only to preserve merchantable timber but also to permit immature timber to ripen and to enable reforestation to take place naturally on cut-over areas.

The growth of timber now taking place is estimated at 1.4 billion feet annually. It is believed that this rate of growth could be more than doubled in the future with effective protection and careful management.

The lumber industry was a decidedly local affair in the Inland Empire prior to 1900 , with nearly all of its product marketed at home. Since then the business has expanded rapidly. Its products now go largely into the great markets of the Mississippi Valley at an average cost for freight of about $\$ 7.50$ per thousand feet. About 1.6 billion feet of lumber is now cut each year.

In view of existing market conditions, the use of raw material in the woods approaches a reasonable standard. The waste of timber merchantable under current manufacuring standards amounts to about 3.5 per cent of the gross estimate of the original stand; about 8.7 per cent is lost through defects and breakage. About 14.1 per cent is left standing in the form of less valuable species which often cannot be taken profitably.

The sawmills of the Inland Empire are operated on the average at less than onehalf of their theoretical maximum capacity; prior to 1917 this capacity was being increased rapidly by the construction of new mills and the remodeling of old.

The mill selling price of lumber for the 6 years ending with 1914 averaged $\$ 14.85$ per thousand feet. During this period the average book charge for stumpage was $\$ 2.67$ per thousand feet of lumber produced, logging cost $\$ 6.13$, and milling $\$ 6.10$, which gives a total of $\$ 14.90$. These figures do not include any interest paid on debts.

The total investment in the industry is about $\$ 135,000,000$, of which $\$ 90,000,000$ is an actual outlay, without interest, for standing timber, and $\$ 15,000,000$ is invested in logging and lumber manufacturing plants. For taxation purposes, this privately owned timber and the land upon which it stands has an assessed value of about $\$ 140,000,000$; if the figures at which it is charged on the books of the companies in connection with logging operations are used, the total value is $\$ 280,000,000$. The investment in the reserve supply of raw material is exceedingly large in proportion to that in manufacturing. The debt in connection with both the timber and manufacturing investments amounts to about one-third of the total.

In 1914, after allowing a profit of 6 per cent compound interest on the actual outlay for the stumpage cut that year, the manufacturing end of the business earned 3.3 per cent interest on its investment. During the period from 1909 to 1914, inclusive, putting in the stumpage cut not at its actual cost but at approximately its going price, and including no interest as a cost, the business earned an average of 1.06 per cent, or less than enough to pay the interest on its debts. Dividends have been paid by some companies operating under exceptionally favorable circumstances, but they are the exception rather than the rule.

The industry pays about $\$ 1,500,000$ taxes annually on its timberland, and about $\$ 500,000$ on its manufacturing plants. About 14,000 people are employed in the industry on the average, with an average annual payroll of about $\$ 14,000,000$; about $\$ 12,000,000$ goes to the railways for freight; several million dollars more is distributed locally in paying supply bills.

The lumber industry is not in a stable condition. This is made evident by the exceedingly small average profits in the business, the existence of much unused milling capacity while additional capacity is being developed, and the constant tendency to cut more lumber than the market will absorb. The principal cause of 
instability is the great pressure to liquidate the stumpage investment. This is due to the necessity for raising funds to pay taxes, interest on debt, fire protection, and timber administration costs; to the belief that stumpage investments will yield no large speculative profits in the future and the natural inclination to realize on a non-income producing property; to the danger in some places of destruction of timber by fire; to the desire to realize on and keep active the manufacturing investment; to the wish to hold down overhead charges per unit of product by a large volume of production; and to the need for holding together the personnel of lumbering organizations and the desire to maintain local communities dependent upon the industry. All this has led to exceadingly sharp competition. Lack of cooperation is one of the most noticeable features of the industry.

Stability in the lumber industry must be the starting point for clean use and systematic renewal of its forest resources. It is equally essential to the prosperity of the local people wholly or in part dependent upon the industry, and to the security of its many investors. The wood-using public will benefit in the long run from greater stability. To that end, cooperation is desirable among lumbermen and between the Government and the lumbermen in many ways which are not adverse to public interests.

The private owner is not now interested in managing his timberland for the continuous production of forest crops, because the rate of profit probably obtainable from such management is less than the interest rate which he has been willing to consider heretofore. Furthermore, he is having difficulty in holding his merchantable timber securely. The public interest demands that streamflow be protected and that wood supplies be produced for the future. As a partial solution to this problem the State and Federal governments should adopt a policy of acquiring timberlands. This should apply particularly to cut-over lands best suited to timber production, to areas of immature timber, and to inaccessible tracts which will not be in demand for many years. In addition, the private owner should learn that the management of forest lands for the continuous production of crops of timber will yield a profit, even though small, and the government should encourage him to engage in this business by making conditions as favorable as practicable through cooperation, wise tax laws, and other means. A more stable form of timber ownership, whether public or private, is desirable so that the pressure to cut and its attendant waste may be reduced.

The lumber industry can do much to increase its own efficiency. For generations the industry has been conducted too largely by rule of thumb and tradition. It is time for it to adopt a more modern scientific spirit. Research needs to be applied in developing better methods. The social welfare of employees must receive more consideration. Cooperation slould be developed in many directions which will make the business sounder, more effective on the technical side, and better adjusted to its markets.

\section{THE RAW MATERIAL-TIMBER AND TIMBERLAND.}

\section{STANDING TIMBER IN THE INLAND EMPIRE}

The Inland Empire has an estimated stand of timber amounting to 277 billion board feet, or about 10 per cent of the standing timber of the United States. This region is still far short of the development which it will some time reach in lumber manufacturing, for it is now producing only 5 per cent of the softwood lumber cut of the country. About 56 per cent of the timber in the Inland Empire consists of two species of soft pine resembling that of the Lake States rather than the harder and heavier pines of the South, which are primarily structural woods; about 30 per cent consists of Douglas fir and larch, which are well suited to structural purposes.

Table 1 shows the quantity of standing timber by species and States. It also gives this information separately for privately and publicly owned timber. The information on which this table is based was obtained from the records of the Forest Service for timber in the National Forests and from previous investigations of the Forest Service on some of the Federal land outside of the National Forests. Information was also obtained from the records of the States and from many individual timber owners. The results of the investigation made by the Bureau of Corporations, ${ }^{1}$ although modified to some extent in the light of later information, furnish an important basis for many of the estimates. The data which Table 1 summarizes are given in greater detail in Table 12 in the Appendix.

${ }^{1}$ The Lumber Industry, in four parts, published by the Department of Commerce and Labor, Bureau of Corporations. 
TABLE 1.-Standing timber in the Inland Empire by States, ownership, and species.

[Log scale estimate in millions of feat board measure.]

\begin{tabular}{|c|c|c|c|c|c|c|c|c|c|c|c|}
\hline ' & 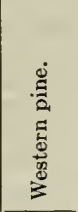 & 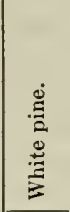 & 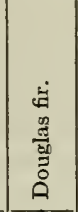 & 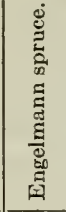 & 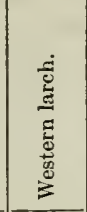 & $\begin{array}{l}\frac{8}{2} \\
\frac{\pi}{0} \\
\frac{0}{0} \\
\frac{0}{0} \\
\frac{0}{3}\end{array}$ & 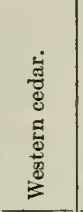 & 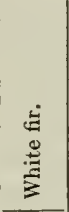 & 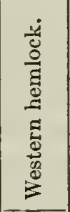 & 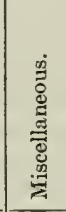 & 苛 \\
\hline 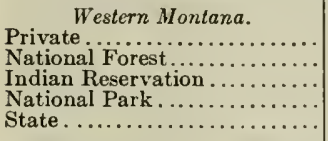 & $\begin{array}{r}4,996 \\
3,609 \\
1,074 \\
170 \\
126\end{array}$ & $\begin{array}{r}186 \\
1,006 \\
\cdots, 20 \\
63\end{array}$ & \begin{tabular}{|r|}
3,004 \\
5,729 \\
358 \\
220 \\
500 \\
\end{tabular} & $\begin{array}{r}842 \\
2,399 \\
\cdots 80 \\
315\end{array}$ & $\begin{array}{r}5,237 \\
5,905 \\
358 \\
210 \\
651\end{array}$ & $\left|\begin{array}{r}32 \\
8,018 \\
\cdots, 60 \\
260 \\
441\end{array}\right|$ & $\begin{array}{r}159 \\
139 \\
10 \\
21\end{array}$ & $\begin{array}{r}305 \\
\cdots \\
\cdots \\
24\end{array}$ & $\begin{array}{r}55 \\
34 \\
\cdots \cdots \\
\cdots \cdots \\
\cdots\end{array}$ & $\begin{array}{r}24 \\
67 \\
\cdots \\
\cdots \\
\cdots\end{array}$ & $\begin{array}{r}14,757 \\
28,215 \\
1,790 \\
1,000 \\
2,201\end{array}$ \\
\hline Total. & 9,975 & 1,275 & 9,811 & 3,636 & \begin{tabular}{l|l}
5 & 12,361 \\
\end{tabular} & 8,751 & 309 & 792 & 89 & 94 & $44 \quad 47,96$ \\
\hline 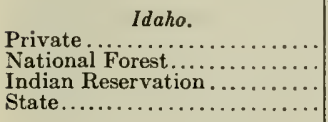 & $\begin{array}{r}6,649 \\
8,017 \\
209 \\
1,917\end{array}$ & $\begin{array}{r}12,327 \\
4,508 \\
3 \\
2,467\end{array}$ & \begin{tabular}{|r|r|}
7,989 \\
3,563 \\
129 \\
2,100 \\
\end{tabular} & $\begin{array}{r}238 \\
4,575 \\
18\end{array}$ & $\begin{array}{r}3,015 \\
2,300 \\
41 \\
1,156\end{array}$ & $\left|\begin{array}{r}77 \\
11,081 \\
56 \\
499\end{array}\right|$ & $\begin{array}{r}2,158 \\
1,629 \\
3 \\
1,024\end{array}$ & $\begin{array}{r}1,660 \\
3,128 \\
\cdots 630\end{array}$ & $\begin{array}{l}360 \\
612\end{array}$ & $\begin{array}{r}70 \\
5,59 \\
41\end{array}$ & \begin{tabular}{r|r}
32 & 30,175 \\
0 & 57,003 \\
444 \\
9 & 10,500
\end{tabular} \\
\hline Total .... & 16,792 & 19,305 & 20,781 & 4,995 & 6,512 & 11,713 & 4,814 & 5,418 & 1,077 & 6,71 & 98,12 \\
\hline 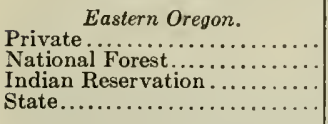 & $\begin{array}{r}27,133 \\
25,397 \\
8,032 \\
72\end{array}$ & $\begin{array}{r}115 \\
1 \\
\ldots\end{array}$ & $\begin{array}{r}2,103 \\
7,870 \\
1,883 \\
7 \\
\end{array}$ & $\begin{array}{l}41 \\
\ldots .\end{array}$ & $\begin{array}{r}590 \\
3,116 \\
232 \\
5\end{array}$ & $\left|\begin{array}{r}382 \\
4,737 \\
1,654 \\
7\end{array}\right|$ & 327 & $\begin{array}{r}236 \\
12 \\
1 \\
5\end{array}$ & $\begin{array}{l}28 \\
64\end{array}$ & $\begin{array}{r}1,34 \\
4,95 \\
\cdots\end{array}$ & \begin{tabular}{r|r}
32,144 \\
46,682 \\
411,803 \\
4 & 100 \\
\end{tabular} \\
\hline Total & 60,634 & 116 & $\begin{array}{ll}6 & 11,863 \\
\end{array}$ & 41 & 3,943 & \begin{tabular}{l|l|}
3 & 6,780 \\
\end{tabular} & 327 & 254 & 92 & 6,30 & 90,72 \\
\hline $\begin{array}{l}\quad \text { East } \\
\text { Private } \\
\text { National } \\
\text { Indian R } \\
\text { State...... }\end{array}$ & $\begin{array}{r}8,071 \\
4,032 \\
3,880 \\
610\end{array}$ & $\begin{array}{l}473 \\
133 \\
255\end{array}$ & \begin{tabular}{|r|r|}
3,638 \\
6,373 \\
1,337 \\
260
\end{tabular} & $\begin{array}{r}393 \\
723 \\
102 \\
3 l\end{array}$ & $\begin{array}{r}1,182 \\
1,355 \\
871 \\
50\end{array}$ & $\mid \begin{array}{r}119 \\
1,069 \\
361 \\
\ldots \ldots\end{array}$ & $\begin{array}{l}333 \\
486 \\
255\end{array}$ & $\begin{array}{r}61 \\
321 \\
152 \\
20\end{array}$ & $\begin{array}{r}149 \\
877 \\
3 \\
30\end{array}$ & $\begin{array}{r}29 \\
1,47 \\
\ldots \ldots\end{array}$ & \begin{tabular}{r|r}
14,718 \\
16,848 \\
7,213 \\
1,000
\end{tabular} \\
\hline Total. & 16,593 & 861 & 11,608 & 1,248 & 3,458 & 1,549 & 1,074 & 554 & 1,056 & 1,77 & $78 \quad 39,77$ \\
\hline Grand Tota & 103,994 & 21,557 & 54,063 & 10,300 & 0) 26,274 & 28,793 & 6,544 & 7,018 & 2,314 & 15,73 & $36.276,59$ \\
\hline Stat & $\begin{array}{c}\mathrm{Nat} \\
\mathrm{Fo}\end{array}$ & $\begin{array}{l}\text { tional } \\
\text { rest. }\end{array}$ & $\begin{array}{l}\text { India } \\
\text { Reserv } \\
\text { tion. }\end{array}$ & & $\begin{array}{l}\text { ational } \\
\text { Park. }\end{array}$ & State. & & $\begin{array}{l}\text { otal } \\
\text { ablic. }\end{array}$ & Priva & ate. & Total. \\
\hline $\begin{array}{l}\text { Montana ....... } \\
\text { Idaho ........... } \\
\text { Oregon ........ } \\
\text { Washington.... }\end{array}$ & & $\begin{array}{l}8,215 \\
7,003 \\
6,682 \\
6,848\end{array}$ & $\begin{array}{r}1,7 \\
4 \\
11,8 \\
7,2\end{array}$ & & $\begin{array}{l}1,000 \\
\ldots \ldots \ldots\end{array}$ & $\begin{array}{r}2,20 \\
10,50 \\
10 \\
1,00\end{array}$ & & $\begin{array}{l}33,206 \\
67,947 \\
88,585 \\
25,061\end{array}$ & & & $\begin{array}{l}47,963 \\
98,122 \\
90,729 \\
39,779\end{array}$ \\
\hline Total... & & 8,748 & 21,2 & & 1,000 & 13,80 & & 84,799 & 91,7 & 794 & 276,59 \\
\hline
\end{tabular}

The information in both tables is given in units of $\log$ scale $^{1}$ rather than the quantity of lumber which can be sawed from standing timber. It is customary for lumbermen to think of standing timber in terms of log scale, although of course always recognizing the fact that there is generally a material overrun of lumber cut over $\log$ scale. This overrun ordinarily amounts to about 20 per cent; sometimes it does not exceed 8 per cent; and sometimes it runs as high as 33 per cent. The amount depends upon the character of the logs and how completely the sawyer utilizes them. The method and care taken in scaling greatly affect the overrun. The scaling practice varies materially from one operation to another, and is in need of standardization.

Timber estimates, even when very carefully made by the most reliable men, are subject to error, and the estimates for much of the timber in the Inland Empire were not carefully made. The less careful the estimate and the earlier it was made, the more conservative it usually is. It is probable, therefore, that the estimates given for the Inland Empire are on the whole between 5 and 20 per cent too low, and the Idaho estimates are probably somewhat more conservative than those in the other States. If, as seems reasonable, the estimates should be increased by 10 per cent to get the actual log scale of the standing timber on the ground, and if the cut of lumber obtained from the logs exceeds the log scale by 20 per cent, the standing timber in

1 By the Seribner Decimal C Log rule. 
the Inland Empire will actually cut out 32 per cent more in lumber than the estimates here given.

On the other hand there is a loss between the sound logs in the standing tree and the logs delivered on the saw deck, owing to breakage in felling, waste in sawing trees into logs, loss through the inadvertent or intentional leaving of timber or logs in the woods, breakage, damage or other loss in minor transportation (especially in live chuting), loss from breakage, sinkage, and strayage in stream driving, a slight loss from railway cars in transit, breakage in unloading logs from car to mill pond, and deterioration in transit through checking, rot, etc. For these losses as they usually occur, however, allowance has been made in the figures given for overrun. Thus, if the overrun percentages here given are correct, and if the timber were all accessible, 365 billion board feet of lumber could be sawed from the estimated stand of 277 billion board feet in the Inland Empire.

Another factor of uncertainty affecting this whole matter is the degree of utilization, which is discussed elsewhere. In the estimates given here it is assumed that utilization will not vary much from the present practice.

Table 1 shows a total of slightly under 16 billion feet of "miscellaneous" species. This includes greater or less quantities of all the other species listed. This is because for a given tract the estimator is especially interested in the leading species present, and primarily in the more valuable species. Other species which occur only incidentally are grouped as "miscellaneous." This classification includes exceedingly little white pine or yellow pine, a small amount of larch and Douglas fir, and some cedar and Engelman spruce; it consists mainly of white fir, lodgepole pine, and hemlock.

\section{THE CHARACTER OF FOREST LANDS}

Table 13 in the Appendix shows that the total area of what may be called forest land in the Inland Empire is about 54.5 million acres. This acreage includes considerable areas of high mountains covered with bare rock or meadows. At lower elevations there are many open meadows suitable for grazing. The land of this kind amounts approximately to 6.4 million acres. There are also large areas of woodland in which the trees, although of considerable age, will probably never be suitable for sawlogs. These areas are valuable in protecting the sources of streams, but they are of little or no importance as producers of timber for commercial purposes. Altogether there are about 7.9 million acres of this character of land.

Approximately 36.3 million acres of land, unsuited to agriculture, is of such a character that it will produce commercial timber. This land is divided into 3 classes: (1) areas not at present forested but which may be forested by planting or other means, 1.5 million acres in all; (2) areas now bearing young timber not yet of merchantable size but which will become merchantable if protected, 4.7 million acres in all; and (3) areas upon which there now stands timber of merchantable size suitable for logging, 30.1 million acres in all.

The land now bearing merchantable timber but which may best be devoted permanently to agricultural purposes when cleared includes about 3.9 million acres.

\section{SPECIES OF TIMBER.}

Table 1 shows that there is estimated to be approximately 277 billion feet of standing timber in the Inland Empire, of which about 67 per cent is publicly owned. Of this amount only 21.6 billion feet is white pine, the most highly prized of all of the species thus making up less than 8 per cent of the stand. The Inland Empire has, however, 41 per cent of all the white pine in the United States. About 60 per cent of the white pine is privately owned. Western yellow pine-western soft pine, western white pine, or western pine ${ }^{1}$ as it is commercially known-makes up approximately 104 billion feet, or 37.5 per cent of the total stand. It is estimated that there is approximately two hundred billion feet of western pine in the United States, so that the Inland Empire has over half of it.

Approximately 9.5 per cent of the entire stand is larch, which exists in the United States in considerable quantities only in the Inland Empire. Nearly 20 per cent of the total stand is Douglas fir, but this is inferior in quality to that in western Washington and Oregon for it does not produce nearly so high a percentage of the better grades of material.

\section{PRIVATE ACQUISITION OF TIMBERLAND}

One-third of the timber of the Inland Empire has passed from public to private ownership. The title to most of this changed hands between 1900 and 1907 during

1 For this species the term "western pine" is used in this publication, for it is the name by which the species is best known commercially. 
a period of very active timber purchasing. At present comparatively little timber is changing hands.

What object had private individuals or corporations in seeking title to the timberlands in the Inland Empire? A large amount of money had been made in timber investments in the Lake States prior to 1900. The Lake States lumbermen began to see the end of their virgin timber supply, which had once been thought inexhaustible. Most of these men had done well in the lumber business and wished to stay in it. They looked for a new supply of raw material as the basis for future operations.

At this time, especially in connection with a growing sentiment for forestry, there was much discussion of the possibility of a timber famine. Substitutes for lumber had not yet cut seriously into its markets. The consumption of lumber had been increasing up to 1900 at least in proportion to the increase in population. The creation of Federal forest reserves in advance of a well developed plan of administration and use appeared to lock up considerable areas of timberland from use.

Influenced by all of these factors, lumbermen east of the Rocky Mountains began to look to the West for new supplies of timber and for the profitable investment of money made in the business. Others who were not lumbermen but had heard of large profits in the timber business began also to look to the West with a view to timber speculation. The year 1900 marks approximately the beginning of a strong demand for the timberland of the Inland Empire; the timberlands of the Coast Fir region and of California had been in demand for some time before. In 1900 prices for stumpage were very low, but with the growing demand prices began to climb rapidly.

The United States was originally the owner of all of the land in the Inland Empire. Timber passed readily from Government ownership into private hands under the Federal land policy. The Northern Pacific Railway land grant included the oddnumbered sections to a distance of approximately 40 miles on each side of the main line of the railway. Large quantities of timberland were disposed of under the Timber and Stone and Homestead acts. Some passed by grant to the various States, and thence into private hands.

Aside from any question of actual frauds in the Inland Empire, there was a very considerable amount of land which could not have passed into private hands had the Homestead and Timber and Stone acts been strictly enforced. The Government land policy-already exceedingly generous-was made all the more so in effect by the plan of administration, which made the salaries of registers and receivers depend largely upon the amount of land passed from Government to private ownership.

Very naturally, a loose administration of the public land laws resulted. A "Iand conscience," as it is called, developed in the West; and many men felt its influence. The fraud which frequently occurred in connection with timber claims was rather largely on the part of individuals, although sometimes promoted by men who wished to assemble large tracts of timber for some particular lumber company or to be sold at a profit to a lumber company.

The public land laws, under which this situation developed, were wholly unsuited to the economic situation, which required that the lumber industry develop on a fairly large scale rather than with a little saw mill for every 160 acres of timberland, as the Timber and Stone act apparently contemplated. For the timberland frauds which took place the government must accept a share of responsibility, since the laws were inadequate to economic needs and were laxly administered. At the same time the western demand for the rapid distribution of public resources which was fostered by land speculators and lumbermen, as well as by many other elements in the western States, had a large part in influencing the land policy of the Government.

The period of most rapid acquisition of timberland in the Inland Empire began about 1900 and lasted for the next five or six years. By 1909 the timber not already privately acquired had for the most part been included in National Forests and was no longer available.

Data gathered in connection with this investigation show that purchases of the following quanties of stumpage, in millions of feet, were made in the years given:

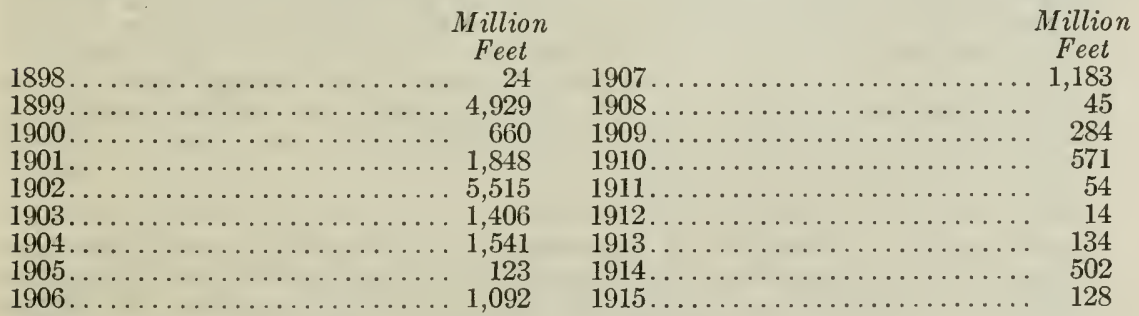

None of these purchases were directly from the United States. 
These purchases amount to 20 billion feet only, out of the 92 billion feet privatel owned in the Inland Empire. 'They are considered fairly representative, however, as to the time of acquisition by the present owners, and represent the process of building up their holdings.

Large holdings, frequently based on purchases from the Northern Pacific Railway Company or from States, developed in many places in the Inland Empire, typically in northern Idaho. western Montana, and in Oregon. The development of these larger holdings and the concentration of ownership is discussed at considerable length in the report of the Bureau of Corporations. At present there is little indication of further tendeney on the part of large owners to increase their holdings. The large timber owners are now buying but little timber, usually only for immediate cutting or for strategic reasons. Since 1910, when the Bureau of Corporations' data were collected, comparatively little timberland has changed hands in the Inland Empire. The expression "Is timber an asset or a liability?" was decidedly common in 1914 and 1915, an indication of the changed point of view which makes the timber owner hesitate to increase his holdings. Many of the small owners who were holding out for large prices about 1909 were by 1915 anxious to get the timber off their hands; while the larger owners are usually refraining from buying, although they can frequently get these small holdings at a lower price than that asked several years ago.

\section{ACCESSIBILITY OF TIMBER}

It is roughly estimated that on the basis of the pre-war wage scale 20 per cent of the Inland Empire timber can be logged to the mill for less than \$1 per thousand feet log scale; 22 per cent will cost between $\$ 1$ and $\$ 7$ to log; 28 per cent will cost between $\$ 7$ and $\$ 10$ and 30 per cent will cost over $\$ 10$. The privately owned timber is on the whole much more accessible than the public timber.

Calculations were made for representative portions of the Inland Empire showing the accessibility of timber privately and publicly owned. The resulting tables are designed to show the cost, under pre-war operating conditions, of getting timber from the stump to a mill located on a common carrier railroad either now in existence or which will, in all probability, be constructed within the next 30 or 40 years. The tables separated the timber in to two classes: that accessible to existing railroads, and that accessible to projected railroad routes. The timber was then separated into four other classes: (1) stumpage which could be logged from the stump to the mill-site at a cost of less than \$t per thousand feet log scale; (2) timber subject to 3 logging cost between \$1 and \$7; (3) timber under a logging cost from \$7 to \$10; and (4) timber under a logging cost of over $\$ 10$. Three main timber types were recognized: western pine stands, consisting of over 50 per cent of western pine; white pine stands, consisting of more than 25 per cent of white pine; and mixed stands, embracing all timber not included in the other two types.

It was found impracticable to prepare tables of this character for the entire Inland Empire, but the principal timbered regions were included; namely, western Montana, Idaho north of the Salmon River, and all of Oregon east of the Cascades, eastern Washington, southern Idaho, and the small portion of Wyoming are omitted. The areas included contain approximately 72 per cent of all the timber in the Inland Empire. The data from the three regions covered are summarized in Table 2. Further details are given in Table 14 in the Appendix. While these tables are necessarily rough approximations, it is believed that they will fulfill their object of indicating in a general way the relative degree of accessibility of the timber, both private and public.

In Montana only 0.3 of 1 per cent of the timber, all in the western pine type, falls in the class of that which could be logged for less than $\$ 1$ per thousand feet. This timber is $\$ 3$ per cent privately owned. The class which could be logged for between $\$ 1$ and $\$ 7$ per thousand feet includes 18.1 per cent of all the timber; of this class 40 per cent is privately owned and approximately 80 per cent is in the mixed type. The $\$ 7$ to $\$ 10$ class includes 35.1 per cent of the timber in western Montana, of which over 90 per cent is in the mixed type: only 23 per cent of it is privately owned. Of the Montana timber 46.5 per cent will cost more than $\$ 10$ to log; this is all in the mixed type and it is only 16 per cent privately owned. For western Montana these generalizations may be made; the most valuable timber, that in the western pine type, is the most accessible; the most accessible timber is very largely privately owned; the least accessible timber, consisting of the least desirable species, is mainly in the hands of the Government.

Table 14 in the Appendix shows that in northern Idaho the timber is on the whole somewhat more accessible than in Montana and that the public owns a higher percentage of all of the timber, both accessible and inaccessible. Here again the western pine type includes rather largely the most accessible timber. In Oregon the timber is decidedly more accessible than in either Idaho or Montana, and in this 
State a considerable quantity of comparatively accessible timber is publicly owned. The timber in the south Idaho region is somewhat similar in accessibility to that in Montana; while the eastern Washington timber is probably somewhat comparable with that of north Idaho.

TABLE 2.-Accessibility of timber in the Inland Empire.

\begin{tabular}{|c|c|c|c|c|c|c|}
\hline \multirow[b]{2}{*}{ Class (based on logging cost. } & \multicolumn{2}{|c|}{ Private. } & \multicolumn{2}{|c|}{ Public. } & \multicolumn{2}{|c|}{ Total. } \\
\hline & $\begin{array}{l}\text { Amount } \\
\text { (million } \\
\text { feet). }\end{array}$ & Per cent. & $\begin{array}{l}\text { Amount } \\
\text { (million } \\
\text { feet). }\end{array}$ & Per cent. & $\begin{array}{c}\text { Amount } \\
\text { (million } \\
\text { feet). }\end{array}$ & Per cent. \\
\hline
\end{tabular}

WESTERN MONTANA.

\begin{tabular}{|c|c|c|c|c|c|c|}
\hline 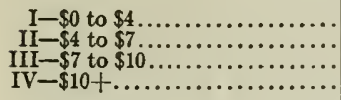 & $\begin{array}{l}120 \\
3,836 \\
5,300 \\
5,470\end{array}$ & $\begin{array}{l}.8 \\
26.0 \\
36.0 \\
37.2\end{array}$ & $\begin{array}{r}24 \\
4,840 \\
11,530 \\
16,880\end{array}$ & $\begin{array}{l}14.1 \\
34.7 \\
50.7\end{array}$ & $\begin{array}{r}144 \\
8,676 \\
16,830 \\
22,350\end{array}$ & $\begin{array}{l}.3 \\
18.1 \\
35.1 \\
46.5\end{array}$ \\
\hline Total.............. & 14,726 & 100.0 & 33,274 & 100.0 & 48,000 & 100.0 \\
\hline
\end{tabular}

NORTHERN IDAHO.

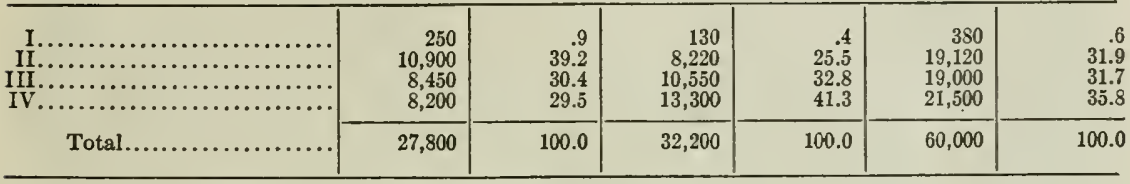

EASTERN OREGON.

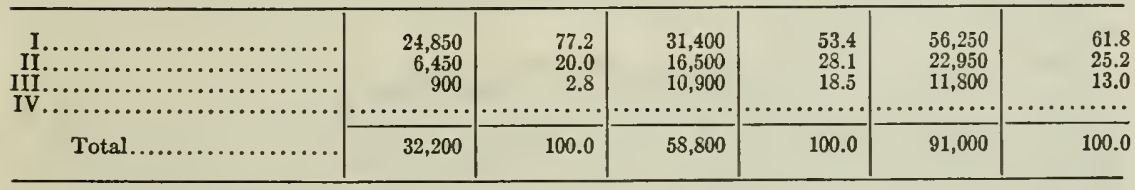

As has been the case everywhere, cutting in the Inland Empire began in the most accessible timber, principally in the western pine type. Cutting has been extended subsequently to more and more remote timber. This is shown by Table 6 , indicating the average cost of logging in different years. The extension of the cutting from the western pine into the less accessible white pine type is also shown by a study of figure 15 in the Appendix, indicating the percentage of various species produced in different years. This shows that the cut of western pine dropped from 76 per cent in 1900 to 39 per cent in 1915 . Future cutting must be extended to more and more remote timber as the accessible supplies are exhausted. It surprises one to note the great difference in the accessibility of the stands which are now being logged; some mills are securing their timber supplies from decidedly inaccessible stumpage.

The northwestern Montana region has about 25.2 billion feet of standing timber. For several years prior to 1916 it was cutting about 150 million feet of lumber per year, at an average cost of logging not far from $\$ 5.25$ per thousand feet, $\log$ basis. It was estimated that about 100 million feet of the standing timber could be logged for less than $\$ 4$ per thousand feet, 4.5 billion for between $\$ 1$ and $\$ 7,9$ billion for between $\$ 7$ and $\$ 10$, and that 11.6 billion would require over $\$ 10$. In order to justify cutting at all, as operations move back from zone to zone, either present stumpage values and operating costs will have to be reduced or, what is far more likely, the price of lumber at the mill will have to increase steadily.

Brief consideration of the ownership of timber with relation to accessibility makes it clear that cutting in the immediate future must be mainly in the privately owned timber. As the more accessible zones of timber are exhausted the importance of the publicly owned timber as a source of supply will increase.

There is, as indicated by the tables, a large quantity of timber in private hands which is decidedly inaccessible. Approximately 13.7 billion feet in Montana and north Idaho could not be logged for less than $\$ 10$, pre-war wage scale, and about the same amount in the two States would cost between $\$ 7$ and $\$ 10$ to log. Although a considerable part of this 27.5 billion feet is railway grant timber, other private 
owners sometimes acquired timber which is inaceessible and ean not be profitably logged under present market conditions. The least accessible of the privately owned timber may not become marketable for very many years, especially if the prices for lumber and stumpage remain at a level determined larkely by the quantity of accessible timber that can readily be put on the market. The relative accessibility of Coast and California timber as compared with that in the Inland Empire also has an important bearing on this question.

It would doubtless be wise, as part of a broad public policy of acquiring eut-over lands suitable for permanent forest management aiming at the production of timber and the protection of watersheds, to secure and place under public management suitable portions of the privately owned inacessible timber.

\section{GROWTII OF TIMBER, PRESENT AND FUTURE}

The most reliable data available indicate that the timber of the Inland Empire is growing in volume at the rate of about 1.4 billion board feet annually, making no allowance for losses by fire damage. Of course fire, which causes great losses, can not be disregarded. It is discussed at another point. This rate of growth ean be greatly inereased in the future under skillful forest management which secures a full restocking on cut-over areas. It must be emphasized that thoroughly effective fire protection is essential if this growth is to be secured and utilized.

In an attempt to get at the fundamentals of forest economies in the Inland Empire it is desirable to determine, as nearly as practicable, the probable future growth of timber under various conditions. Table 13 in the Appendix shows for the various regions of the Inland Empire: first, the growth which it is estimated is now taking place; second, the growth which would take place if all of the timber were barely ripe for eutting or still younger, and had been produced without intensive silvicultural management but with adequate fire protection; and third, the possible growth if none of the timber were overmature and all areas were managed so as to secure a maximum yield from each acre of timberland through having a complete stocking of desirable species.

Table 15 in the Appendix indicates the estimated rotation for the various forest types occurring in the Inland Empire, or the earliest age at which the timber of a given type becomes merchantable for cutting, together with the average annual growth which will take place under three different specified eonclitions. For the western pine type, it is considered that a rotation of 120 years will be needed to produce saw timber. Western pine of this age is not of course up to the quality of that now being eut, but after the present supply of virgin timber is largely gone, much younger, smaller, and lower quality timber will be marketable. Timber of this type which is now fully mature and from which fire has been excluded is estimated to be growing at the rate of 25 board feet per acre each year.

Fires in the past have not damaged this type nearly so badly as the white pine type or the larch-fir, spruce, lodgepole, and other types; but they have eaused a large and insidious damage which takes various forms, such as fire sears at the butts of trees causing a loss in the butt logs, burning trees off occasionally, killing reproduction or even old trees at times, stimulating insect damage and rot, etc. This and other sources of damage have had the effect of offsetting the growth in mature western pine stands, over large areas, so that the average acre does not bear nearly so large a volume of timber as there would be if fire had been excluded during the past two hundred years. If fire is prevented, a net growth is set up in the average stand which is estimated to be approximately 25 board feet per acre each year. In other words, if a merchantable stand of western pine now averages 10,000 board feet per acre and fire is kept out for 20 years, the stand will then yield 10,500 board feet per acre. This rate of increase is believed to be conservatively estimated. The net increment for merchantable timber in other types is estimated similarly.

The growth of mature or overmature stands is not nearly so rapid as that of young stands which have not yet reached maturity. From data collected by the Forest Service in various types it is estimated that before reaching maturity timber produced from natural reproduction grows at the rates indieated in Table 15, Appendix; that is, where no efforts have been made to secure a full stand but fire has been kept out. Natural reproduetion with a fair degree of stocking ordinarily follows eutting operations in the Inland Empire if fire is exeluded. The average growth of young western pine is estimated to be 60 board feet per acre each year.

Where natural reproduction is supplemented by leaving seed trees, or seeding or planting to secure a full stand, eliminating the open spaces which invariably occur here and there in natural stands, it is estimated that the average annual growth 
will be increased 50 per cent. Under this condition the average growth of young western pine will be increased to 90 board feet per acre per year.

These, estimates were prepared in detail in order to show approximately what growth is now taking place in different regions in the Inland Empire and what growth may be expected in the future under different conditions. Detailed data not published herewith show that northwestern Montana contains 588,000 acres of young timber now growing at an average rate of 73 feet per acre per annum; that there are 2,679,000 acres of mature timber standing on land permanently suited to timber production and 707,000 acres of mature timber on land suitable for agriculture when cleared, both now growing at the rate of 38 feet per acre per annum. In northwestern Montana as a whole the annual growth is now 171 million board feet.

As the old timber is gradually removed by cutting, more and more of the land which is suitable to the permanent production of forests will have young rather than mature timber growing upon it. This change from mature timber with a comparatively slow growth to young timber with a comparatively rapid growth will increase the total annual production of the region. When the condition is reached, which of course cannot be for very many years, that none of the timber is overmature but all of it is making the good growth possible in young stands, the growth in northwest Montana will be 258 million feet per year, as compared with 171 million feet now. This estimate is based upon natural reproduction only, with no artificial reforestation to fill in natural openings, and assumes that fire damage is eliminated.

If the forests are intensively managed so as to bring each acre to its greatest productivity, it is safe to assume that the production of northwestern Montana can be brought up to 387 million feet.

Similarly, it is estimated that the present annual growth in the entire Inland Empire is approximately 1,400 million feet, and that if none of the timber were overmature the growth would be 2,500 million feet annually. If intensive forestry were practiced, including the planting of blanks, the yearly production would reach 3,700 million feet. Probable fire losses must be deducted from these estimates to get at the net growth. As indicated under "Forest Protection and Losses" it is believed that the annual fire loss can be held below an average amount of approximately 300 million feet.

\section{FOREST PROTECTION AND LOSSES}

Beginning about 1905, as the result of both private and public enterprise, a protection system has been developed, which has considerably reduced losses due to fire. In the past fifty years, however, fire has done an immense amount of damage in the forests of the Inland Empire. Tree diseases and insects also do much damage, and in many respects are more difficult to control than fire.

Fire protection is essential in connection with all of the timber types in the Inland Empire. Even in the western pine type, least susceptible of any in the region to fire damage, the best estimates available indicate that careful protection of mature stands results in the accumulation of an average net annual growth of 25 board feet per acre where otherwise fire and other losses practically offset growth. Thus a rough balance has existed between growth on the one hand and decay, fire, and insect damage on the other. Taking very large areas of western pine into consideration, the total quantity of timber has probably been about the same for thousands of years back, excepting as modified by exceptionally severe fires and recently by cutting. If fire had been prevented during the past 200 years, far more timber would be available in the western pine and other timber types. With western pine stumpage at $\$ 2$ per thousand feet, 25 feet is worth 5 cents, while it costs only a fraction of 5 cents per acre per year to protect the western pine type from fire. Furthermore, the elimination of fire also prevents damage to the quality of the timber. The loss in volume from fire is largely in the old trees now ripe for cutting, and the growth replacing them is largely on the smaller trees of poorer quality. In other types still greater damage is done by fire than in western pine.

Before the country was settled by the whites, it is believed that fires ran through the western pine type at intervals of perhaps 20 years on the average; through the lodgepole forests, once in 40 to 60 years; through the white pine type, once in 50 to 80 years; and through the larch-fir type once in 40 to 70 years. Of course this does not mean that every acre in any of these types was burned over so often; small areas have possibly escaped fire for more than a thousand years, while other areas have burned very frequently.

The settling and development of the Inland Empire by the white race since 1850 has increased the sources of fire hazard materially. The principal human causes of fire are railroads, brush burning, logging operations, campers, prospectors, etc. From 1850 to 1905 the white man increased the fire hazard of the Inland Empire, 
doing little or nothing to protect the forests from the fires that he started. The Forest Service started its protective work in 1905, and the private protective associations began their work in North Idaho in 1906 . Before this time the General Land Office, while administering the Forest Reserves, made some efforts at fire protection.

There are certain factors which tend to make privately owned timberland a greater risk than National Forest timberland. The oldest and most valuable stands, which would suffer the greatest loss in case of fire, are largely in private hands; while the younger, less valuable stands and less valuable types of timber are in the hands of the public. Furthermore, the logging operations going on mainly in privately owned timber increase the probability of the occurrence of fire. As the merchantable stands now privately owned become older the fire risk becomes greater. On the other hand the private timber is more accessible, so that it is easier to get to the fires to put them out.

It is impossible to estimate with any degree of certainty the losses from fire which have taken place since 1900 , or to attempt any estimate at all of those before that time. Even in the last few years, since private and Federal forest protection have greatly reduced losses, the records are decidedly incomplete and subject to error. It is very crudely estimated that in 1910 three billion feet of public timber and one billion feet of private timber were burned. Again in 1914 it is estimated that 100 million feet of public and 400 million feet of private timber were burned in the Inland Empire. These are by far the most serious fire years that the Inland Empire has seen since systematic fire protection was undertaken. These years, which were probably closer together than dangerous fire years ordinarily come, have clearly demonstrated the greatly increased efficiency of fire protection in 1914 over 1910. Hence 1914 is a better basis of estimating future losses in bad years than 1910. Means of detecting and getting to fires are being improved in the forests of the Inland Empire; and it is reasonable to believe that, with intelligent, energetic efforts at protection in the future, the average annual loss will diminish. With a probable loss of 500 million feet of timber in a bad fire year such as 1914, with a fair system of protection which will probably be bettered materially in the future, and with comparatively little fire loss in the moister years, such as 1911, 1912, and 1913, which usually intervene between the bad fire years, it is believed reasonable to estimate that average annual fire losses in the future will be less than 300 million feet.

Forest insects are responsible for insidious losses which in the aggregate are very large. Much of this sort of damage is usually overlooked by the casual traveler in the forest who does not recognize the work of insects as causing the death of many trees scattered more or less regularly along his path. Occasionally, under conditions favorable for insects, the rather evenly distributed normal losses are greatly increased by insect epidemics which kill a large proportion of the trees of certain species over considerable areas. The ordinary losses from insects are allowed for in the estimates of growth. Different species of trees vary in their susceptibility to insect damage; white pine is especially susceptible. Far greater efforts than those made in the past are required to reduce the damage from this source.

Fungus diseases rot the heartwood of trees and cause damage in other ways. Tree diseases cause an enormous total loss, although the loss is a hidden one and varies with the species of timber and type of forest. In some cases of very defective stands the total loss in yield of merchantable timber is as much as 25 per cent. The best information available inidicates that the losses from decay in stands now being logged average about as follows for the various species: western pine, 4 per cent; white pine, 12 per cent; Douglas fir, 5 per cent; spruce, 2 per cent; larch, 5 per cent lodgepole pine, 2 per cent; cedar, 20 per cent; white fir, 25 per cent; and hemlock, 30 per cent. The average for all species is put at 6 per cent. Allowance for this source of loss has been made in the estimates of stumpage and growth. Forest pathologists of the Bureau of Plant Industry are working in co-operation with the Forest Service upon the solution of this problem. Under intensive management, losses from decay can be greatly restricted by removing infected trees at each cutting and by logging stands before disease becomes widespread or far advanced.

While it is not possible to secure commercial insurance against any of these forms of loss, preventive and control measures will generally pay for themselves many times over. Although organized efforts at protection have greatly reduced fire losses in Inland Empire timber, there is still much room for improvement in the protective systems. Federal and State governments especially nust expect to spend large sums in developing their protection systems to the point where the timber resource is reasonably safe. Among many necessary measures it is especially important to make the forests more accessible by the construction of roads and trails.

Table 16 in the Appendix shows the total expenditures and the expenditure per acre by each of the Idaho associations and the Northwest Montana Association. 
Similar data are given for nearby National Forests where conditions are similar except as to accessibility. Table 16 shows that the north Idaho associations had spent prior to 1915 over $\$ 600,000$ on about $1,600,000$ acres in their fire protective work, an average annual expense of $\$ 0.064$ per acre or $\$ 0.0035$ per thousand feet of standing timber. The expenditures on the north Idaho National Forests are slightly lower per acre but higher per thousand feet of timber protected, for the average stand per acre is much greater on the privately owned land than on National Forest land. Owing to the comparative inaccessibility of the National Forests, they are harder to protect than the privately owned timber.

While the Forest Service is looking forward to the future and is providing for the reforestation and careful protection of cut-over areas, the private owner is doing little or nothing in this line except incidentally. He is protecting his mature timber, but is not interested in the young growth excepting in very rare cases and then for sentimental rather than practical reasons. The welfare of the public in the future demands that areas of young growth and cut-over areas bearing reproduction, on land suited best to the permanent production of timber, be protected from fire.

\section{UTILIZATION OF TIMBER IN LOGGING OPERATIONS}

The degree to which stumpage is utilized in the woods is important alike from the points of view of the stumpage owner, the operator, and the public. Utilization has varied materially with the market conditions existing at different times, the accessibility of the stumpage itself, and the ideas of the individual operator. Since 1909 the closeness of utilization has decreased in some ways and increased in others. The less complete utilization occurred especially in 1914, when lumber market conditions were particularly bad; subsequently there was an improvement in both market and degree of utilization.

A number of sample areas in the cuttings of various operators and of various years were accurately measured to determine the degree of utilization. The results, given in Table 3 , show that on the average 26.3 per cent of the original stand was left on the ground, either standing or down. This is divided into merchantable material cut and left, cull material cut and left, and standing merchantable timber.

Of the total original stand, 3.5 per cent which would be considered merchantable under Forest Service scaling practice was cut and left on the ground. This is net scale after making deductions for cull. ${ }^{1}$ On the sample area showing the maximum amount of merchantable material left, the waste was 7.8 per cent; the minimum was .3 per cent. This material was in the form of logs, high stumps, merchantable tops and long butts.

The logs were those left by accident where partly hidden by snow or brush, broken logs still containing merchantable material, and poles left in skidways Waste in this class of material average 2.6 per cent, with a maximum of 6.1 per cent and a minimum of .2 per cent. Loss of this sort varied somewhat with the operator but not with the time of cutting.

High stumps are those cut unnecessarily high above the root swelling, thus wasting merchantable material. On well supervised Forest Service operations there is no loss from this cause. Loggers who have operated on the National Forests show the effect of the low stump requirement when operating later on privately owned land, and some private operators have developed very good practice in this respect. In this respect utilization has improved with time. The average loss from high stumps is .4 per cent; maximum 2.1 per cent, minimum zero.

${ }^{1}$ Logs were scaled to a six-inch top limit for white pine and eight inches for other species. White pine logs containing not less than 33 per cent and other species containing not less than 50 per cent of sound material were considered merchantable. White pine logs less than 8 feet long and other logs less than ten feet long were considered unmerchantable. 
[Based on 22 aecurately mensured, representative sample plots, averaging 3.13 acres each, in northern Idaho. Cutting done 1908 to 1915 .]

\begin{tabular}{|c|c|c|c|}
\hline \multirow[b]{2}{*}{ 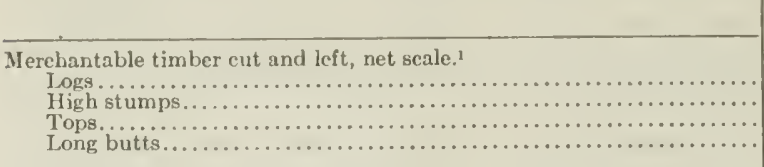 } & \multicolumn{3}{|c|}{ Per cent of total original stand. } \\
\hline & $\begin{array}{c}\text { Average } \\
2.58 \\
.40 \\
.32 \\
.21 \\
\end{array}$ & $\begin{array}{l}\text { Maximum } \\
6.13 \\
2.08 \\
2.85 \\
2.26 \\
\end{array}$ & $\begin{array}{l}\text { Minimum } \\
\quad .24 \\
\cdots .01 \\
\cdots \cdots \\
\end{array}$ \\
\hline Total........... & 3.51 & 7.78 & .33 \\
\hline 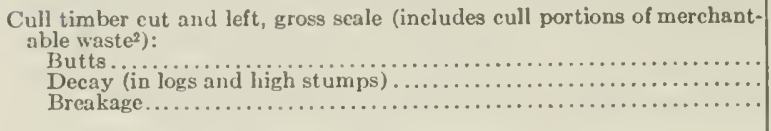 & $\begin{array}{l}1.09 \\
5.91 \\
1.66\end{array}$ & $\begin{array}{r}8.36 \\
20.16 \\
6.66\end{array}$ & $\cdots \cdots$ \\
\hline 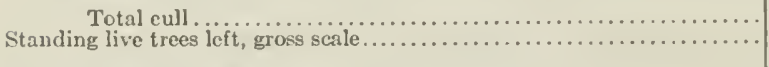 & $\begin{array}{r}8.66 \\
14.13 \\
\end{array}$ & $\begin{array}{l}22.40 \\
60.64 \\
\end{array}$ & $\begin{array}{r}1.72 \\
\cdots \cdots \\
\end{array}$ \\
\hline 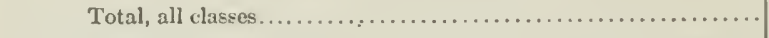 & 26.30 & 67.81 & 6.06 \\
\hline
\end{tabular}

1Defect has been dedueted in computing net seale. Firm blue and red stain not considered defect. Sixinch top limit for white pine, eight inches for other species. Not over $662 / 3$ per cent defect allowable in merehantable white and yellow pine logs; not over 50 per cent for other species.

2 Includes the gross contents of all pieces cut and left which contain larger percentages of defect than those indicated in note above.

Merchantable material is left in tops as the result of failure to utilize to the merchantable top limit; logs are oftentimes cut from tops and then left. Loss in tops varies s lightly in different operations, and has not been much affected by time. It averaged .3 per cent, had a maximum of 2.8 per cent, and a minimum of .01 per cent. Long butts include pieces shorter than the customary log lengths, of merchantable quality but culled by the sawyers. The waste in this case was .2 per cent; maximum 2.3 per cent, minimum zero.

The unmerchantable material left consists of butts, logs, and high stumps unsound from decay or shakes, and breakage. This material cannot be regarded as waste, since its utilization is clearly not practicable under existing market conditions. It includes defective portions of the merchantable material left in the woods, but does not include defect in material removed from the cutting area. The quantity of cull for defect varies with the age and location of the timber. The total quantity of cull averaged 8.7 per cent, maximum 22.4 per cent, and minimum 1.7 per cent. The cull butts were principally shaky larch; the loss from this cause averaged 1.1 per cent, with a maximum of 8.4 per cent and a minimum of zero. The decay in logs and high stumps averaged 5.9 per cent, with a maximum of 20.2 per cent and a minimum of zero.

Some breakage is unavoidable; it is greater in the denser stands, in the larger and taller timber, and on the steeper slopes; it is materially increased by lack of care in felling, especially when good sized timber is felled down hill. Larch especially is easily broken and makes up a considerable proportion of the total. The loss from breakage averaged 1.7 per cent, maximum 6.7 per cent, minimum .08 per cent.

During 1914 especially, with the low price of lumber, there was a strong tendency on the part of many operators to locate their cuttings in stands containing high percentages either of white pine or western pine; and even in such forests the tendency was to leave standing considerable quantities of the less valuable species, especially larch, Douglas fir, and cedar. During the winter of 1915-16, with the improvement of the lumber market, considerably more of these species were cut. On the average a gross scale has been left in standing trees of 14.1 per cent; maximum 60.6 per cent, minimum zero.

The less valuable species left standing because they cannot be removed at a profit are in unusual danger of fire loss, windfall, and insect damage, owing to the changed condition of the forest brought about by the cutting. Even if no loss occurs from these sources it is doubtful in many cases whether an operator will later be able to log these species by themselves unless they are very accessibly located.

The utilization requirments of the Forest Service are indicated in the previous footnote. In the Lake States white pine is cut to a 4-inch top, Norway pine (corresponding somewhat to western pine) and spruce to a 5-inch top, tamarack (larch) and balsam (white fir) to a 6-inch top; shorter and more defective logs than in the Inland Empire are also taken. This sort of utilization pays in the Lake States because the stumpage is about four times as valuable and because a nearby market exists for the entire product of the smaller logs. The application of the Lake States 
standard in the utilization studies just mentioned would, of course, show a much greater percentage of waste.

The utilization in many cases has shown a lack of definite standards for the individual operator or for the region as a whole. No information has been available to date to show conclusively what logs it is profitable to take under a given set of conditions; whether, for instance, where the cost of logging to the mill is $\$ \$$ per thousand feet, a 20 -inch surface clear white pine log 70 per cent defective can profitably be taken. Information of this character can be secured only through careful research, which small operators cannot afford. The present method is too often to leave the foreman to use his own judgment as to what he takes, and this is largely because the mill man himself usually cannot tell him any better.

There is a large amount of misinformation as to what kinds of logs will sink or float in stream driving. Some operators decline to put logs in the water that other operators are taking consistently. They believe the logs will not float, although others have definitely proved that logs of the character in question do float. On the other hand, it is doubtless true that some operators are taking out logs which cannot be profitably handled. Until accurate, detailed information is available, no one can tell under what conditions it pays to take certain classes of logs from the woods.

The stumpage owner wishes to see the closest possible utilization of his timber (excepting the trees to be reserved for reforestation purposes, in the case of the Forest Service). The logger and mill man wishes to take only such timber as will be profitable. The public interest in the maintenance of a permanent supply of timber for consumption, and in making the virgin supply last as long as possible, lines up with that of the stumpage owner in the desire to see very complete utilization. It also supports the policy of the Forest service in reforesting and protecting cut-over lands which should be devoted permanently to forest production.

On the whole it is clear that when lumber prices have been satisfactory woods utilization has been much closer than at times when prices have been low. High prices justify the expense of logging certain classes of material which cannot be profitably handled when prices are low.

\section{TAXATION OF TIMBERLAND}

Taxes on standing timber in the Inland Empire average about 1.7 cents per thousand feet annually; or to look at it from another angle, it takes $\$ 1.10$ from the selling price of each thousand feet of lumber manufactured each year to pay the timber tax bill. The property tax system, which taxes year after year a crop which can yield a revenue only once in one hundred years or more, tends to force premature cutting. It is highly desirable that some equitable form of yield tax be adopted for timberland, so that taxation may tend to conserve rather than to destroy prematurely this great natural resource.

The data available on this subject indicate that in Iclaho taxes now amount annually to approximately 1.5 cents per thousind feet of standing timber. In Oregon taxes amount to slightly less than this; in Montana they amount to approximately 2 cents per thousand feet annually; while in 11 ashington they average about the same as in Montana. These differences are loubtless due to the varying relations between the needs of the different states for funds, the wealth of the state available for taxation, the development of the jarticular region, and especially the attitude of the local assessors in determining stumpage values. As between States at least, taxation appears to bear no definite relation to the value and accessibility of timber. Idaho has 37 per cent of white and western pine, while Oregon has 67 per cent of western pine. The latter on the average is more accessibly located than the Idaho timber to the extent of $\$ 3$ less in logging costs, vet taxes in Idaho are slightly higher than in Oregon. In all cases the taxation per acre or per thousand feet of timber has been increasing quite regularly since 1900. For the Inland Empire the average annual taxes for the 12 years prior to 1915 was about $1 . t$ cents, and had reached 1.7 cents at the end of that period.

In the case of one company in northern Idaho the taxes amounted to the following number of cents per thousand feet from 1902 to 1914 , inclusive: $0.71,0.56,1.59,1.1$, $0.96,1.21,1.37,1.14,0.9,1.11,1.15,1.43,1.54$. The increase is due no doubt to the increasing need of the State resulting from the growth in population and the construction of more costly public works. It is also due to the increased number of county governments and the rising value of stumpage since 1902 . In the case just cited, which is regarded as rather typical, the increase in the tax per thousand feet has not kept even with the increase in stumpage values. In 1902, stumpage of similar character had an average value of less than $\$ 0.50$ per thousand feet; in 1909 it had an average value of about $\$ 3$; and in 1915 it had an average value of about $\$ 2.50$ per 
thousand feet. Thus while the tax per thousand feet had a little more than doubled, the value of the timber had multiplied 5 or 6 times.

An examination of eonditions in Washington under the direction of the Forest Serviee in 1912 indieates that farm lands bear the lightest percentage of assessment, or approximately 25 per eent of their actual value, while timber lands are assessed at approximately 33 per cent and city real estate at approximately 40 per cent. The lumber stocks in mill yards are assessed in some cases at a figure nearer their actual value than most other forms of property in the vicinity.

Many people favor the application of the property tax system to standing timber, since it is a form of wealth to which a large unearned increment has accrued. Thus through taxation, the pullic, which originally owned the timberland, will take back to itself a part of the unearned increment. At any rate the loeal public usually cloes not know or sympathize with the taxation difficulties of the man who owns inature timber, but generally fecls that he secured the timber in the course of speculation, has done very little to enhance its value excejt to expend perhajs a fraction of a cent per thousand feet yearly in fire protection, and that the taxes now collected do not take an unfair proportion of the unearned increment already aecrued.

One large timber owning company, cutting at a rate which will exhaust its virgin supply in about 95 years, is now paying taxes on its timberland equivalent to about $\$ 1.55$ per thousand feet of lumber cut annually. The taxes of another owner with about 60 years supply amount to $\$ 0.75$ per thousand feet on the cut. For the Inland Empire as a whole, timberland taxes amount to about $\$ 1.10$ for each thousand feet of lumber produced from logs cut from privately owned lands. For companies whose annual cut is sufficient to climinate the timber holding, in apjoroximately 20 years, the taxes on timberland amount to about 25 cents per thousand feet of lumber cut.

The difficulty with the present system of taxation is that it requires the timber owner to raise annually a considerable sum of money with which to pay taxes on a form of property which in the main is producing no income. Nany owners feel that they must secure this money from the manufacture of lumber. This tends to force the eutting of more lumber than can be readily marketed, and leads to the evils of over production. A system under which the taxes would be payable when the timber is cut, that is, a yield tax, would remove this pressure. In a region like New Fngland, where virgin timber is largely gone, where second growth timber is taking its place and owners must hold the growing forest for a long while before it will be ripe for cutting, the people are interested in raising timber and are therefore making progress toward scientific tax laws for forest lands. Timberland should, of course, bear its share of taxes; but the method of applying the tax should be such as to eneourage wise utilization rather than to hasten the rapid cutting of timber, with incomplete utilization and without provision for reforestation.

If the scheme of taxation were changed to a yield basis in the Inland Empire and it were considered necessary to raise the same public revenue from timber, the tax would amount to approximately $\$ 1.30$ per thousand feet on the cut from privately owned land. In any case, a yield tax would tend to check rather than hasten cutting, and would thus be a conserving factor. The present system of taxation may readily be decidedly unfair to timber owners; uncertainty as to the future of timber taxation is another of the forces leading owners to cut timber as rapidly as possible; it also has a tendency to discourage private owners from managing their lands with the object of continuously producing erops of timber.

The lumber industry as a whole pays yearly taxes in the Inland Empire to the extent of approximately two million dollars. In some of the timbered counties of northwest Montana and northern Idaho the industry pays from 15 to 30 per cent of the taxes. The lumber industry is an important source of tax revenue, and as such its welfare should be carefully considered by the public. The whole matter of taxation is a deep problem which this report does not pretend to solve. It is merely desired to point out here that it is a vital public as well as inclustrial problem which deserves serious consideration.

\section{NATIONAL FOREST TIMBER POLICY}

Lumbermen have sometimes feared that National Forest timber would be sold in such large quantities and at such prices as to depress further the unsteady lumber market. Such fears have had a psychological effect in tending to make stumpage investments appear less desirable. It is the policy of the Forest Service to increase the use of national forest timber in order to reduce the deficit ineurred for the protection and administration of the Forests and to compensate the States and counties more adcquately for the withdrawal of property from taxation, ${ }^{1}$ as well as to supply igitimate demands made upon the forests. Under the conservative system of

I I I \& I 1

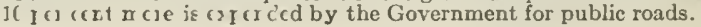


appraisals followed, however, and the requirement that timber purchased be manufactured immediately, the sales made have been only those logically required for the supply of established mills or the normal expansion of the industry in particular regions. The fear that national forest timber may be dumped on the market at bargain prices is unfounded.

\section{TIMBER BONDS AND COST OF TIMBERLAND ADMINISTRATION}

The bonded indebtedness of the companies cutting lumber in the Inland Empire is approximately four million dollars. The bonds are usually based on both timberland and operating plant. If the amount of the bonds is divided between timberland and plant in the same ratio as their respective investments, about 40 per cent of the value of the bonds would be chargeable to timber. It is probable, however, owing to the fact that a considerable part of the combined plant and operating investment is not "fixed," that much more than 40 per cent is actually secured by timberlands. These bonds usually pay 6 per cent interest, but with brokerage charges and discounts the borrowed money ordinarily costs between $61 / 2$ and 7 per cent.

Stockholders' notes are a more common form of debt and make up a considerable amount. It is estimated on the basis of the known condition of about 20 per cent of the private holdings that the debt on all of the private timberland in the Inland Empire amounts to about $\$ 25,000,000$, or $\$ 0.27$ per thousand feet of standing timber. At 6 per cent this requires about $\$ 1,500,000$ to meet annual interest payments, about $\$ 1$ for each thousand feet of lumber produced annually in the Inland Empire, or about $\$ 0.016$ per thousand feet on the standing timber. A considerable part of this interest is paid by issuing new notes.

A discussion of the various forms of debt will be included in connection with the finances of operation. The main point here is to indicate that there is a considerable debt on the timber of the Inland Empire, and that it is one of the forces tending to promote the cutting of stumpage.

The costs of administration of timberlands, including estimating, supervision, legal expenses, etc., have not been determined accurately; they vary decidedly from one company to another. As nearly as can be estimated, however, approximately one-fifth of a cent per thousand feet annually on the standing timber is a fair amount to allow for this expense.

\section{TIMBER CUTTING}

RATE OF CUTTING STUMPAGE.

In the period from 1906 to 1915 inclusive, about 15 billion feet of lumber was produced in the Inland Empire; in the previous 50 years there was cut, probably, about 11 billion feet, which gives a total of 26 billion. Taking into consideration the type of timberland and the degree of utilization, the cutting probably areraged about 9,000 feet of sawed lumber for each acre cut over; the areas now being cut probably yield about 15,000 feet of lumber from each acre. Thus there has been cut over about $3,000,000$ acres, and cutting is proceeding at the rate of about 100,000 acres per year.

During the ten years prior to 1916 there was produced an average of approximately 1,500 million feet of lumber each year. Allowing a 32 per cent overrun of lumber tally over woods estimate, this means an annual reduction by 1,140 million feet of the estimated amount of standing timber. The present average rate of cutting (based on the three years 1913 to 1915 inclusive) is approximately 1,600 million feet of lumber, or 1,210 million feet of stumpage. This does not take into account the timber cut for other purposes than to be sawed, as that cut for fuel, posts, poles, hewn ties, round mine timbers, pulpwood, etc. The available data indicate that the equivalent of about 25 million board feet in the form of cedar poles and about 35 million feet in the form of hewn ties, a total of 60 million, is cut per year from material that could be used for saw logs. A considerable additional amount is taken from material not suitable for saw timber, neither as by-products of logging operations or in thinnings.

Table 17 in the Appendix shows for 1912 the rate of cutting by timber species and by regions, contrasted with the total stand of timber. New mills started since 1912 have greatly increased the cut from such regions as the Deschutes, where the cut was very small in proportion to the available supply of timber.

The data show that the present rate of cutting in the Inland Empire is not diminishing the timber supply with great rapidity. It must be kept clearly in mind, however, that the development of new uses for wood, the expansion of the pulp and paper industry, and the inevitable decrease in production of such regions as the Lake States and the South, will bring new demands to the Inland Empire.

Of the cut of approximately 1.6 billion feet of lumber in the Inland Empire in 1914, 15 per cent was obtained from the National Forests, while nearly all of the 
remainder was cut from privately owned land. 'The National Forest cut was relatively most important in the Klamath and Deschutes regions, where 42 per cent of the lumber came from this source. In northern Nlontana 35 per cent came from the National Forests; in eastern ()regon 21 per cent; in the Coeur D'Alene region 18 per cent; in the Missoula region 16 per cent; in the Pend Oreille region 14 per cent; and in other regions a rather negligible amount. (See 'Table 18 in the $A$ ppendix.)

PRLSSURE TO CUT THMBR.

A strong pressure is apparent on the part of Inland Empire stumpage to seck a market. The existence of this pressure means a constant tendency to overproduction. Private owners have numerous reasons for desiring to cut their timber. The taxation of standing timber year after year tends toward the confiseation of its value; and the owner frequently feels the necessity of eutting at least a part of the timber in order to raise funds with which to pay taxes. The uncertainty as to the policy of the Federal Government in disposing of its timber has its effect. The timber of the Inland Empire is mortgaged more or less, as is shown in another place, and frequently timber must be cut to raise the interest needed annually. In northern Idaho especially, but for the most part of little importance clsewhere, fire danger tends to stimulate cutting to some extent. The white pine type of northern Idaho is also especially susceptible to insect damage, another cause of the pressure to cut. In most cases, furthermore, the investment in timber has been running along for a number of years without much return to the owner who is anxious to realize, especially since opinions among lumbermen indicate more or less doubt about the returns on such investments in the future. The question is sometimes asked, "Is stumpage really an asset, or is it a liability?" Other reasons arise in connection with lumber manufacturing operations to stimulate cutting, which will be discussed under "The Productive Industry."

\section{THE VALUE OF TIMBER}

For the privately owned timber of the Inland Empire the present owners paid an average of 77 cents per thousand board feet (timber estimate basis), the average date of purchase being January 1, 1904. Taxes have inereased the outlay by an average of 1.3 cents per thousand feet yearly; fire protection has had an average annual cost of 0.13 cents; administration has cost 0.2 cents per year per thousand feet. Adding these costs the timber owner had paid out, up to January 1, 1916, an average of 97 cents per thousand feet, not including any allowance for interest. Some believe (the writer does not) that "constructive" interest should be added as a cost. If constructive interest had been added at the rate of 6 per cent compounded, the stumpage would have stood on the books at an average of $\$ 1 . \$ 3$ on January 1, 1916. 'The stumpage cut in 1914 (the latest year for which information is available) was charged as an operating expense at $\$ 3.06$ on a timber estimate basis.

Timber had an average price of about 30 cents per thousand board feet in 1900; by 1907 it had reached about $\$ 1.75$, most of the rise having taken place during 1905 and 1906 . Prices remained stationary until about 1913 , but since that time stumpage had declined somewhat in selling value. It does not now appear probable that there will be material inerease in price during the next few years; and after that it appears unlikely that stumpage will increase in value fast enough to earn more than 3 or 4 per cent compound interest on a present conservative valuation.

\section{ORIGINAL COST OF STUMPAGE.}

Practically all of the privately owned stumpage was acquired from the United States, the original owner, through railroad grants, State land grants, lieu selections (mostly railway), the Timber and Stone Act, or the Homestead Act. In the case of the railway and State grants no money payment was made to the Government. For timber land acquired under the Timber and Stone Act the Government received approximately $\$ 2.50$ per acre. Since the timber so acquired ordinarily ranged from 6 to 30 thousand feet per acre, and in the Inland Empire as a whole averaged about 11,000 feet per acre, the stumpage cost, if the land be considered valueless, was approximately 23 cents per thousand feet.

In the case of land acquired under the IIomestead Act the claimant obtained the land with its timber without cost, excepting for practically negligible fees, if he succeeded in convincing the Land Office that he had made his home on the land for 5 years. Otherwise, by making commutation proof at the end of 14 months', actual or alleged residence, the land was secured by the payment of $\$ 2.50$ per acre within and $\$ 1.25$ outside of railway grant limits. Since a large part of the timberland so acquired is within railway grant limits, the stumpage cost averaged about 20 cents 
per thousand feet to the original entryman, who usually obtained title through commutation.

Railway grant timber still held by the railway will be left out of consideration in discussing stumpage values, since it was acquired under conditions entirely different from those under which other stumpage was obtained. Timber began to be privately acquired in considerable quantities about 1898. The earlier purchases of railway grant and Idaho state timber were at rates varying from about 10 to 60 cents per thousand feet.

The persons securing timberland under the Timber and Stone or the Homestead act usually retained ownership for a short time only and then sold to various lumber companies, timber owning corporations, or speculators. A "claim" of 160 acres, originally costing $\$ 100$, would be sold to a lumber company by the original claimant for anywhere from $\$ 500$ or $\$ 600$ up to $\$ 12,000$ or $\$ 15,000$. These figures represent the usual minima amd maxima, although occasionally surpassed. The higher prices were paid after 1905 , and for heavy stands of valuable species. These prices, figuring on an average stand of about $\$, 000$ feet per acre for the lower prices and 30,000 feet for the higher prices, indicate a range from 40 cents to $\$ 3$ per thousand feet. Most claims, even in the early days of stumpage dealings, probably sold at a rate to net from 60 cents to $\$ 1$ per thousand feet for the timber. Nost of the timber purchased from the State, the railway, or original entryman still remains in the hands of the first purchasers, if no consideration is given to reorganizations which sometimes changed company names.

Table 19 in the Appendix shows that, for purchases of approximately 21 billion feet the records of which were obtained in the investigation, the average price paid was 70 cents per thousand feet. These prices are all on a stumpage estimate basis, and the estimate is that given in this report rather than the earlier estimates, which were usually lower. These purchases took place during a period of 18 years, from 1898 to 1915 inclusive, with a weighted average date of purchase of about January 1,1904 . If the railway timber not yet sold, amounting to about 15.5 billion feet, is left out of account, about 30 per cent of the timber in private ownership is represented in these purchases.

There is included relatively little of the timber secured from the United States under the Homestead or Timber and Stone Acts. Such timber passed into the hands of the present owners, mainly timber or lumber companies, at prices averaging between 60 cents and $\$ 1$ per thousand feet. The privately owned timber not accounted for in Table 19 amounts to about 54 billion feet. Combining 21 billion feet at an average price of 70 cents with 54 billion at 80 cents gives a weighted average price paid by the present owners of 77 cents per thousand feet.

In the case of over 90 per cent of the privately owned timber, timber and land were bought together, the land usually being considered practically valueless. In the prices here given the entire initial investment is charged against the timber and none against the land, This is considered reasonable since the land had little or no value when most of the timber was purchased. The value remaining in the land after the removal of the timber will be discussed later in this report.

\section{MOVENENT OF STUMPAGE PRICES.}

Figure 2 shows the movement of stumpage prices from 1898 to 1915 for some of the timber which actually changed hands. In timber purchases from private owners from 1898 to 1905 the price averaged between 25 and 30 cents per thousand feet (see Table 19, Appendix). The earlier prices represent mainly large transactions rather than those involving single claims; usually the claims brought higher prices than are indicated.

In 1906 the recorded prices show a great jump. The rather violent ups and downs since that time are more apparent than real, depending upon the position and strength of the seller and the amount sold more than upon the average going price of timber at that time. The accessibility and quality of the timber also play an important part in its price, which can not be brought out clearly in a graphic presentation.

Figure 13 (Appendix) gives the stumpage prices on National Forests separately for different types of timber. The white pine type includes stands in which 25 per cent or more of the volume is white pine; the western pine type includes stands of which 50 per cent or more is western pine; and the mixed type includes all other classes of green timber. The price in each sale is reduced to a flat average, although usually, especially in the white pine and western pine types, different prices are set for different species, depending upon their relative values. The appraised price of a number of unsold logging chances in the white pine and mixed types is also given.

The conditions under which sales of National Forest timber are made differ materially from the usual type of private sale. In Forest Service sales no large 


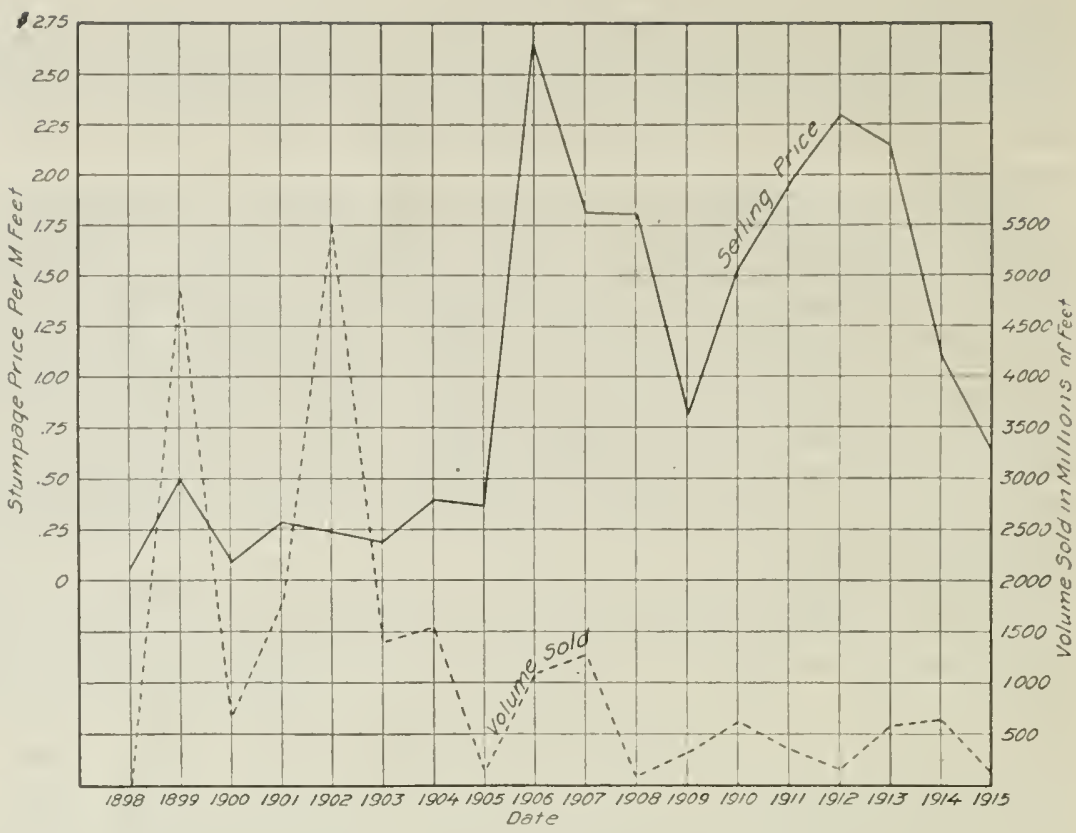

STUMPAGE PRICES AND VOLUME OF TIMBER SOLD

BY PRIVATE OWNERS, THE STATE OF IDAHO, AND THE US FOREST SERVICE

investment in stumpage is necessary, since the timber is paid for in installments immediately before it is cut; the Government assumes the risk of loss on the uncut timber and the cost of protecting it, and the operator is relieved of timberland taxes. These advantages are off set to a large extent by the requirements as to leaving seed trees, protecting young growth, brush disposal, and, in the case of long period sales, price readjustments.

Taking all classes of sales into consideration, it may be said the prices of stumpage in the Inland Empire show a rise between 1895 and 1907, most of the rise taking place from 1905 to 1907 , a more or less stationary level through 1913, and since that time a moderate decline. The data available for exhibition do not show this so clearly as it is impressed upon the mind of the writer through experience gained in the region since 1908, and especially in this study of the lumber industry.

The very rapid increase in stumpage prices just before 1907 occurred during a period of general prosperity in business throughout the country. Rapid buying of stumpage in the Inland Empire was reflected in rising prices. The cut increased from about 560 million feet in 1899 to 1,350 million feet in 1907, but the demand for stumpage increased far more rapidly. This was partly due to the large profits made in timber in the Lake States just before and during this time, which had a considerable influence on men's ideas of the future course of stumpage values and which were available for reinvestment in the West, where the last of the white pine was to be found.

Then came the panic of 1907, with its depressing effect upon the industry. In spite of this, 1909 was a good year. The belief had become well fixed in the minds of all interested that stumpage prices would never go down; and with this in view there was a feeling for several years after 1907 that, while stumpage was not moving briskly, still the period of stationary prices would be temporary and would be followed ultimately by another substantial rise. There have been comparatively few large transfers of stumpage since 1907. A few occurred as a result of the activity in the lumber business in the fall of 1915 .

During 1914 and 1915 stumpage prices went down somewhat. Several reasons may be given for this tendency. A strong pressure to cut timber had developed. As a consequence the mill capacity of the region had expanded materially, to such an extent in fact that the used mill capacity is only 50 per cent of the theoretical maximum capacity. Then beginning about 1913 a voice was raised occasionally 
expressing the idea that stumpage is a serious burden and that the industry would be better off if the Government had not parted with its timberland but had handled it under something like the Canadian license system. Furthermore, there has come a realization of the enormous amount of timber in the Western States, and with it the thought that very many years will be needed to cut it all. Many had speculated or invested in timber in the belief that it was a rapidly disappearing commodity, whereas it did not disappear fast enough to yield the profits which had been anticipated.

With this feeling that stumpage is not such a profitable commodity to own as had once been thought, developed a desire to be rid of it, which has contributed to a fairly constant state of overproduction. At times, in response to crop and general business conditions, the market has become unusually good for the time being, as in the summer and fall of 1912 and following the fall of 1915. These temporary spells of strong demand have reduced yard stocks and stimulated cutting all the more. The flurry in 1912, for example, largely due to the excellent demand stimulated by unusual conditions, caused applications for the purchase of National Forest timber in northern Idaho and western Montana aggregating 18 billion feet. By the time maps and estimates were completed preparatory to the sale of part of the timber, the flurry was over and practically no large sales resulted. The same thing was repeated on a smaller scale in the summer of 1916.

Overproduction, while rather constant, has not made itself evident so much through the actual stocks in mill-yards and their elfect on the market as through potential conditions in the industry. With only one-half of the theoretical capacity utilized, the operators are ready and anxious to turn out vastly greater quantities of lumber than can be marketed. This potential overproduction, together with a far smaller amount of actual overproduction, held the market price down after 1909 ; while during the same period costs of production rose somewhat through the decreased accessibility of timber, increasing labor costs, and increasing tax and interest charges.

\section{STUMIAGE CARIYING COST.}

The original investment in stumpage does not by any means represent all of the cost of the timber to the owner at the time of cutting. The earliest purchases, gen erally speaking, were made at the lowest prices, but on the other hand have had to bear carrying charges for the longest time. Since only about 20 years have elapsed on even the oldest purchases, carrying charges have not yet increased the first costs to a very great extent. Taxes have varied from one-half cent per thousand feet in the earlier days up to two to five times that amount. They averaged 1.3 cents per thousand feet during the period, and at its close about 1.7 cents.

In northern Idaho especially, considerable money has been expended for the protection of the timber from fire; $\$ 620,000$ was expended from $190 \$$ to 1914 inclusive, by the protective associations, with an average of approximately one-third of a cent per thousand feet per year. In the entire Inland Empire the average annual expense for the protection of private timber from fire since 1903 has been about 0.13 cents per thousand feet.

Administration expenses, including the cost of cruises made from time to time, handling timber records in the office, protecting timber from trespass, conducting legal work in connection with timber holdings, etc., have averaged approximately one-fifth of a cent per thousand feet annually.

The losses are still more difficult to estimate, since in most cases the private owners themselves do not know what they have been. Even for such a fire year as 1910, when it is known that the loss was considerable, definite figures are rarely available. It is probable that in 1910 more than 2 billion feet of privately owned timber in northern Idaho and western MIontana was damaged more or less by fire. Altogether it is roughly estimated that 3 billion feet of privately owned timber had been so damaged down to the close of 1915 , or using 12 years as the average period of ownership, approximately 250 million feet per year. This annual damage by fire represents approximately 0.3 per cent of the timber privately owned in the Inland Empire. It is impossible to say how much timber has been killed by insects.

In Table 13 (Appendix) it is estimated that the privately owned timber is now growing at the rate of about 270 million feet yearly. The rate of growth has not changed materially during the past 10 or 15 years. It is believed, therefore, that while fire has probably destroyed 250 million feet annually, the loss has been about offset by growth. While this is probably true for the private timber as a whole, it is small comfort to individual owners who have seen all or large parts of their timbor holdings practically wiped out by fire with no insurance.

To what extent shall interest be considered as a cost? Some companies borrowed money to be used in buying timber. In these cases interest forms an actual outlay. 
In some instances money was borrowed from storkholders of the companies and the interest paid by the issuance of notes. Interest on such notes was in some eases at the rate of 5 jer eent per annum and in a few exceptional cases as low as 4 jer ecnt, simple interest; but generally the interest rate has been about 6 per cent.

On the private stumpage of the Inland Fimpire as a whole it is estimated that there is an average debt of about 30 cents per thousand feet; 10 yer cent interest on this amount gives a present annual charge of 1.8 ('ents per thousand feet. This debt has been increasing, and it is estimated that its amount has been such that an average of 1.2 cents per thousand feet yearly during the 12-year average period of ownership will cover the interest on it.

Interest is an actuil outlay only on the part of companies using borrowed money and to the extent that borrowed money is used. The distinction between owned and borrowed money is frequently merely a matter of business convenience in financing an enterprise. It is of course important to the proprietor of the enterprise whether he finances it with owned or borrowed ciljital, but the enterprsie itself is not concerned with the source of the rapital. The same is true of a public or economie viewpoint of the lumber industry. We are interested in the carnings of an enterprise or of the industry rather than with the division of earnings among those who furnished the eapital. From this point of view, interest is not a cost at all but a hoped-for return. 'The only real costs are the initial expense of accuiring the timber together with the eontinuing expenditures for tixes, protection, and administration; to add interest to these is merely a process of eapitalizing the expected or hoped-for returns from the timber.

As a specific example, one company bought a considerable quantity of timber, prineipally in 1902, the cost averaging 22 cents per thousand feet. In this case the taxes have averaged 1 cent per thousand feet per vear, or 13 cents for the period under consideration. For protection during 8 years one-fourth of a cent per year should be added, and for other annual exjenses, one-fifth of a cent. The actual outlay for this timber has thus been 39.6 cents per thousand feet. If 6 per cent compound interest is figured on all of these outlays, the actual cost plus the interest amounts to approximately 70.7 cents per thousand feet. This particular company is now charging $\$ 5$ per thousand feet on its books as its stumpage cost in connection with cutting operations.

In another case stumpage ras purchased about 1900, at an average price of 49 cents per thousand feet. The taxes for 15 years have averaged $1 \frac{1}{2}$ cents, a total of $221 / 2$ cents. Administration, estimating, fire protection, etc., have added $1 / 5$ cent per year, a total of 3 cents. This gives a total actual outlay of 74.5 cents. Compound interest at 6 per cent on these outlays will add 82.8 cents, bringing the capitalization calculated in this way to $\$ 1.57$ per thousand feet. This company is eharging its timber on its books in connection with its operations at $\$ 1$ per thousand feet.

In another instance a company bought individual claims in 1906 at an average price of $\$ 1.50$ per thousand feet. In this case taxes have added 15 cents to the actual outlay, protection 2 cents, and administration 2 cents, making a total of $\$ 1.69$. Compound interest at 6 per cent would add \$1.25, giving a capitalized value of $\$ 2.94$. The stumpage is now being charged as an operating expense at $\$ 3.72$. This company for several years marked up the book value of its stumpage at an inerease of 6 per cent annually, but stopped the practice when it found the value getting too high.

Again, a company bought timber at an average date of 1907 at $\$ 1.93$ per thousand feet. Taxes have added 10.8 cents, protection 2.4 cents, and administration 1.8 cents; thus the total outlay is $\$ 2.08$. Compound interest at 6 per cent would add $\$ 1.38$, giving a capitalization of $\$ 3.46$. This company for several years charged its stumpage at $\$ 3.50$, but recently reduced it to $\$ 2.76$ as being more in line with the going prices of the species which it owns.

As nearly as can be determined the actual averige outlay to January 1, 1916, for privately owned timber in the Inland Empire, excepting railway timber, has been somewhat as follows, without allowing anything for interest:

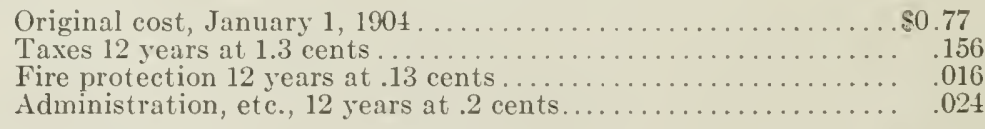

Total. . . .

Compound interest at 6 per cent on these original outlays would add 86 cents per thousand feet, giving a total capitalization of $\$ 1.83$. While the writer does not believe in capitalizing stumpage by adding interest to actual outlay, such caleulations are given to show their effeet. In 1914 this timber was charged on the books of the companies eutting it at an average rate of $\$ 2.32$ per thousand feet, lumber tally, as 
shown in Table 6 , which is equivalent to $\$ 3.06$ per thousand feet on a stumpage. estimate basis.

REALIZATION FROM STUMPAGE; BOOK CHARGE; PROFITS.

While in a given case the actual profit is a definite sum, the methods of measuring it vary widely. One method is to deduct the actual outlay, without interest, from the amount realized and consider the difference a profit. For example, the average money profit on stumpage charged off at the 1914 rate 1 as $\$ 2.09$, the difference between the book charge of $\$ 3.06$ and the actual outlay of 97 cents.

A second method is to express the money profit as a ratio between the actual outlay and the increase in value. For example, the book charge of $\$ 3.06$ minus 97 cents actual outlay equals a profit of $\$ 2.09$, which is 215 per cent of the outlay.

A third method is to take "time" into account by converting the profit per cent into simple interest spread over the number of years that the investment has been running. For example, 215 per cent divided by 12 , the number of years from January 1, 1904, to January 1, 1916, gives 18 per cent simple interest. (This is a short cut method giving only approximate results.)

A fourth method is to assume as a "cost" (really a process of capitalization), some rate of compound interest on the capital invested and to consider the difference between the "cost" thus determined and the price realized as profit. For example, on stumpage cut in 1915 at $\$ 3.06$ per thousand feet, the "profit" above all actual outlays together with 6 per cent compound interest is $\$ 1.23$ per thousand feet. There are, of course, many other ways of measuring or distributing the amount of profit realized.

In discussing "profits" there are certain points which deserve consideration. To be readily and generally understood profits should be expressed in percentages. To say that in a given timber transaction there has been a profit of one dollar per thousand feet has meaning to a lumberman, but is unintelligible to a shoe manufacturer. Furthermore, the time element must be given due consideration by relating the percentage of increase to a definite unit of time, which is commonly the year.

Those who are accustomed to short-time transactions usually think in terms of simple interest; but in the case of investments extending over long periods, say for ten years or more, it is more nearly correct technically to compound interest once each vear. The difference in the rate at which a principal increases under simple and compound interest becomes very great over extended periods. One dollar with simple interest at 6 per cent accumulates to $\$ 1.60$ in 10 years, while with 6 per cent compound interest it accumulates to $\$ 1.79$. In a 20 vear period the same rate of simple interest brings the sum to $\$ 2.20$, and compound interest to $\$ 3.21$. The latter is equivalent to simple interest at 11 per cent.

Under the fourth method cited above, compound interest at six per cent is figured as a "cost" because in some cases the timber owner has borrowed money and is actually paying for it at that rate; in other cases, although the timber owner may have borrowed nothing, he considers that since he could loan his money on excellent security at that rate, the timber venture must yield at least six per cent to pay him for the uise of his capital, and that profits on the venture begin only after the six per cent has been realized. While there is much to justify this point of view, it is considered preferable, rather than to look through the eyes of the owner in account with the timber business, to look through the eyes of the business itself and consider as profit all increases in value above actual outlay. There is a vast difference between figuring compound interest in anticipation of desired profits and figuring it to measure realized profits.

It is believed, therefore, that the best way of measuring profit is to enter only actual outlays under cost, not including interest; and then, after determining the present value of the stumpage cut, calculate the actual rate of compound interest earned on the investment. If $\$ 3.06$ is figured as the return from timber cut in 1915 on an outlay of 97 cents, the rate of compound interest earned is approximately 11 per cent. Similarly, for timber cut from 1909 to 1914, inclusive, the profits as shown by Table 11 have been $32,25,21,17,13$, and 12 per cent compound interest respectively, for the successive years. This rapid decline has been due partly to the declining book charge for stumpage, but more largely to the effect of the time element in compound interest. It should also be borne in mind that the book charge for timber against operating costs is largely arbitrary and has of ten exceeded a reasonable raluation of the stumpage.

It is likely that annual carrying costs will be greater in the fut ure than the average of the past 15 years. They have increased on the whole and are now higher than the average for the period. Furthermore, the relative accessibility of the stumpage cut in the past and in the future furnishes another obstacle to rapidly increasing realization. Table 6 shows that the average cost of logging has increased from slightly over $\$ 4$ per thousand feet, lumber basis, in 1905 to a little less than $\$ 6.50$ in recent years; 
this is equivalent to an increase from about $\$ 1.80$ to about $\$ 7.80 \mathrm{log}$ seale, a difference of $\$ 3$ per thousand feet. During this time the book charge for stumpage rose from $\$ 1.21$ in 1905 to $\$ 1.25$ in 1909 and then fell to $\$ 3.06$ in 1914 . 'The decreasing book charge since 1909 las not kept pace with the decreasing accessibility of the timber cut, to which the increased logging cost is mainly due.

Owing to the manner in which the data on stumpage values have been hanrlled, charging all of the original cost to the timber and none to the land, the value of the cut-over land constitutes an additional profit. Much of the land has no value for any purpose except timber production. 'This would frequently mean no value at all to the private owner, excepting the possibility that the state or Iederal Government may buy it for forest purposes. Some land can be sold for grazing at about $\$ 2.50$ per acre; and some is suitable for agriculture, and can be sold for $\$ 5$ to $\$ 50$ per acre, probably averaging about $\$ 10$. Some areas are barren permanently, or suited only for protection forests. Assuming that 25 per cent is agricultural, at $\$ 10,20$ per cent fit only for forest growing, at $\$ 1$, and 5.5 per eent adapted to grazing, at $\$ 2.50$, the average value of cut-over land is estimated at approximately $\$ 4$ per acre, or about 40 cents jer thousand fect distributed over the timber before cutting. Since cut-over land has been largely retained by the operators, and its value is less definitely established than in the case of the timber, it has been considered inadvisable to include its value as part of the profits discussed above.

For a group of representative companies of the Inland Empire which eut approximately 2,028 million feet of lumber in the three years 1912,1913 , and 1914, the average rate charged for stumpage on the books is $\$ 2.94$ per thousand fect, log scale; or, allowing for a 10 per cent overrun of log scale over stumpage estimate, $\$ 3.23$ per thousand feet of stumpage. These values vary for indivudual companies from an average of 97 cents per thousand feet to $\$ 5.09$. The book values of st umpage are very largely arbitrary, the charge being set at whatever figure the management of the company considers proper. In some cases what appear to be extraorclinary high figures are used, while in others the prices appear decidedly low. The general object is supposed to be to approximate the value of the stumpage at the time it is cut.

In order to secure a check on these figures, competent officers of the Forest service made rough appraisals of the stumpage value which the Forest Service would place on the identical timber which these companies had cut during the 3 year period, if the government had owned it and had offered it for sale. This appraisal showed an average value of $\$ 2.44$ per thousand feet, $\log$ scale, or approximately 50 cents less than the companies charged on their own books.

For the most part the company charges are not very far away from the Forest Service valuation, although the book values of individual companies range from $\$ 2.48$ above to $\$ 1.62$ below the Forest Service appraisals. Furthermore, it must be taken into consideration that most of these book values were fixed about 1908 or 1909, when the Forest Service would unquestionably have appraised the identical stumpage at a higher value than under the conditions existing during the last few years. So, while companies owning stumpage are figuring it at a decided advance over its original cost, it appears that on the average they are charging it at a rate not very far from its present value.

The data given in Table 6 indicate that during the six years from 1909 to 1914 the average selling price of 3,103 million feet of lumber sold by a group of companies was $\$ 14.85$ per thousand fect, while the average cost of production, including depreciation but no interest on capital invested, whether owned or borrowed, and omitting stumpage as an item of cost, totals $\$ 12.23$ per thousand feet. This leaves a margin of $\$ 2.62$ between the $\$ 14.85$ selling price and the $\$ 12.23$ cost of production, available for division between stumpage and profit on the operation. This particular group of companies has charged all of the margin and 5 cents more to stumpage, leaving a 5 cent loss on the operation but yielding profits on the investment in the stumpage cut varying from 32 per cent compound interest in 1909 to 12 per cent in 1914, as shown in Table 11.

It would seem, however, that profits should be distributed between the operating investment and the investment in timberland. If the entire margin of $\$ 2.62$ were credited to the operating end of the business, with nothing for stumpage, 8.3 per cent would have been earned by the investment necessary to produce lumber, no part of which represents investment in standing timber. The proper division of profit between the manufacturing operation and stumpage owner is open to dispute. In the long run any ordinary manufacturing business must earn some profit or cease to exist. The margin between the price obtained for lumber and the cost of production (exclusive of stumpage and interest) would thus have to be divided between manufacture and stumpage rather than be assigned wholly to stumpage. On the other hand, lumber production is not at this time an "ordinary" manufacturing business. Because of the strong pressure to liquidate stumpage, many timber 
owners manufacture and sell lumber with the primary object of getting as much cash as possible out of their stumpage. Lumber manufacture is merely the tail on the stumpage dog.

\section{"COST" OF GROWING TIMBER.}

Table 20 (Appendix) gives the "cost" of growing timber of various types and under various assumptions if timber so produced is capitalized by adding compound interest. Or, to state it in a better way, this table shows the prices which will have to be realized from stumpage if certain rates of compound interest are to be earned as a profit on the investment. Data are given for the principal types occurring in the Inland Empire; namely, the white pine type, occurring principally in northern Idaho and to a limited extent in northwestern Montana; the larch fir type, occurring principally in Montana and northern Idaho; the western pine type, occulring principally in eastern Oregon and Washington but to some extent throughout Idaho and western Montana; and the lodgepole pine type, scattered more or less throughout the Inland Empire. Forest investigations indicate that white pine timber of a suitable size for cutting can be produced in one hundred years. Similarly, the larch fir type requires 120 years to produce timber of merchantable size; western pine can be produced in the same period; lodgepole pine requires 140 years. The yield per acre under present conditions of cutting in each of these types is estimated, both where the stand is fully stocked with trees as by planting, and where the land has reproduced naturally without artificial aid, but with protection from fire. In the first case it is estimated that the white pine type will yield 30,000 feet per acre; in the second case the yield is set at only one-half as much. The yields for the other types as indicated in the table are fixed similarly. These yields have been set down after considering carefully the amounts produced in fully stocked stands and in stands of average stocking examined by the Forest Service.

In case planting is resorted to in order to obtain the larger yield, it is estimated that it will be necessary to spend $\$ 5$ per acre (on the pre-war wage scale) in the planting work. It is also assumed that protection and administration, together with all other annual charges, will cost 6 cents per acre. It is further assumed that the cut-over land can be sold for $\$ 2.50$ per acre for grazing purposes and that it should therefore be entered at this figure as part of the investment of a private operator for raising timber. This cost has not been included in the case of the Government, since it is believed that the land has this value, to the public, when forested, as a watershed protection measure. In other words, the Government is justified by the general public need for protecting stream flow, in carrying an investment of $\$ 2.50$ per acre in the land, whether it is merely a protection forest producing no merchantable timber, or whether it is capable of producing stumpage which can be marketed. The private owner, however, merely chooses between selling the cut-over land for $\$ 2.50$ per acre and carrying an investment of that amount as part of the business of raising timber for sale.

Although taxes are not levied against the Government they must be met by the private owner. In this calculation taxes are entered at 5 cents per acre per year, materially less than the present rate on land bearing merchantable timber. It is hoped that the tax policy of the States will come into better adjustment with timber production in the future, so that the private owner of cut-over land will be less handicapped in growing a second crop.

Under the conditions stated, Table 20 shows that the actual outlay required to produce one thousand feet of white pine from natural reproduction on Government land is $\$ 0.40$, while on privately owned land the necessary outlay is $\$ 0.73$. This is actual cost with no allowance for interest.

Few western lumbermen are now willing to engage in a business in which they see less than 6 per cent compound interest. This is partly due to the large profits once obtainable from timber transactions, partly to the comparatively high interest rates common in the West, and partly to a lack of understanding of the earning capacity of timberland, or indeed of any other investment, over great periods of time, owing to the effect of compound interest. In 100 years $\$ 1$ at 6 per cent compound interest accumulates to $\$ 339.31$, while at simple interest it would only reach \$7. Few, if any, investments grow in value at a rate to keep up for a long period of years with 6 per cent compound interest; and it is certain that timber values will not do so. Owing to the nature of the investment a much lower rate should, however, prove satisfactory to the private investor who is at all inclined to go into the business of raising timber.

In Table 20 , in the case of timber grown by the Government, 3 per cent compounded is figured. In the case of private owners, however, 6 per cent compound interest is the rate used, since most lumbermen feel that at least this rate of interest 
should be earned by the investment. It is considered that the hazard of fire and insect damage has been taken eare of in stating the figures for final yield.

The table shows that, when interest is considered a cost, white pine can be produced by the Government through the use of natural reproduction for $\$ 2.43$ per thousand feet, while the same timber produced by private interests would build up a capitalization of $\$ 9 \$$ per thousand feet. The great differenee is due, of course, to the higher interest rate, the inclusion of a land value, and the cost of taxes in the case of the private enterprise. Similarly, it is calculaterl that western pine can be produced by the Government from natural reproduction for $\$ \times .43$ per thrusand feet; but western pine privately produeed would come to $\$ 586$ per thousind feet.

The figures in this table are given by way of illustrating the effect of different conditions and especially of different interest rates. It is evident, of course, that vastly different results can be secured by juggling with the interest rate. The essential idea which it is aimed to bring out at this point is that, when interest is included as a cost, the Government is able to produce timber at a far lower figure than is the case with private owners, who have taxes and land investments with which to reckon, and who figure with comparatively high interest rates. Private individuals who demand returns involving high interest rates cannot be expected to engage in the business of growing timber under present conditions in the Inland Empire.

However, it is believed that careful study will convince an increasing number of private owners that a compound interest rate much lower than six per eent will furnish a reasonable return. Government action is likely to make conditions more favorable for the private management of forest lands for the production of crops of timber at a moderate profit. The private owner will more and more realize that his cut-over lands contain forest values in the form of half-grown trees, saplings, and small seedlings which, if protected from fire and left to the forces of nature, will grow steadily in quantity and value. These considerations will more and more lead conservative owners to retain and protect their cut-over lands. While the future will doubtless bring such changes, it must be clearly recognized that there is at present little interest along this line on the part of private owners.

FUTURE VALUE OF STUMPAGE.

The present value of stumpage depends upon the expected future ineome from the sale of timber itself or of products derived from it. From this return must be deducted all costs of carrying the stumpage until the income is received. The cost of producing lumber in the future, as well as all other classes of manufactnred goods, will be affected by the cost of supplies and labor. During the 20 years before the war the prices of all classes of products averaged together rose approximately 40 per cent, or at the rate of 2 per cent a year. If prices continue to rise the supplies needed in lumber production will increase in cost and labor must receive a higher wage to bear the increasing cost of living.

The effect of various substitutes upon the price of lumber and hence upon the value of stumpage is important. If the manufacturers of cement and steel are able to lower their costs of production relatively to commodities in general, they will tend to limit the use of lumber more closely than at present. This may or may not take place, although the tendency is to reduce costs of production in these lines.

Furthermore, the future price of lumber in the United States will also be affected by the price at which lumber ean be imported from other countries. The development and marketing of other sources of timber supply, both inside and outside of the United States, is going to be of great importance but must be considered elsewhere than in this report.

How changing types of building construction, the requirements of urban life, and changes in popular demands will finally affect the demand for lumber remains to be scen.

The price of lumber during the next fifteen or twenty years will probably be affected inaterially by the pressure to cut standing timber. If stumpage owners, influenced by increases in taxation, fear of fire losses, a realization of increasing interest outlays, or the desire for immediate liquidation of values, insist upon cutting more lumber than is readily marketable, its price will remain relatively low. With the exceedingly keen competition which exists in the lumber business accompanying a strong pressure to eut stumpage, it appears probable that the price of standing timber will not advance considerably for some time to come.

It has been stated repeatedly that stumpage values must rise to the "cost" of growing timber. Such statements usually imply that the value of standing timber will ultimately equal the cost of its production, including in "cost" actual production expenditures plus compound interest at 5 or 6 per cent on all production expenditures and capital investments. Has this idea a sound economic basis, or is it a fallacy? Turning once more to Table 20 , one sees that white pine can be produced by the 
Government for $\$ 2.43$ per thousand feet, while lodgepole pine can be produced for $\$ 15.42$. White pine is justly a highly prized species, owing to its excellent qualities; it has an established reputation; and it now brings a good price in the Mississippi Valley. It grows in less time and in larger quantities per acre than does lodgepole pine. Furthermore, white pine usually occurs in places from which the cost of getting it to the mill is less than in the case of lodgepole pine; it can be logged with less expense, because the logs are larger; wider boards can be sawed from the logs; and its light shipping weight is another factor favoring a high mill price. Does any one believe that lodgepole pine stumpage will sell ultimately at 6 times the price of white pine merely because lodgepole pine grows more slowly and produces smaller trees and smaller yields than white pine? Not at all. The operation of the laws of supply and demand for the lumber of both species in our most important markets will fix their stumpage values. As previously shown, also, the "cost of production" can be set at any price one chooses within exceedingly wide limits, by juggling with the rate of compound interest.

If stumpage values on Inland Empire timber are not going to be determined by "cost of production" but by competition with outside supplies of timber and with substitutes, what is likely to take place? A consideration of western Europe, especially France and Germany, where timber is in great demand and is imported to obtain a sufficient supply, where forestry has been practiced for centuries, and "costs" of production are fully known, will teach us something on this point. In that part of the world stumpage reasonably well located and in quality similar to our second growth forests about one hundred years old, in which the trees are mostly from 12 to 20 inches in diameter, had a value before the war of from $\$ 16$ to $\$ 24$ per thousand feet; and this in the face of the most intensive demand known anywhere.

The Inland Empire is a very different sort of country from western Europe. It can probably never support so great a population in ratio to acres of timberland. France, for instance, has total area of about 9 per cent small than that of the Inland Empire; it has a forest area of about 23 million acres and a population of about 40 million; there is approximately 0.57 acres of timberland per person. In the Inland Empire, with a population of about $1,100,000$ and a forest area of 40 million acres, there is now about 36 acres of timberland per person, 63 times as much as in France. The Inland Empire, as one of the important timber producing regions of the United States, will probably always export a considerable quantity of timber and its products, so that its stumpage values will be related to lumber prices in markets in the Mississippi Valley. This means a transportation cost of $\$ 7$ to $\$ 9$ per thousand feet, which the French forest product does not have to bear, for French forests are close to French markets. It is believed that we must look forward to but moderate rises in stumpage values and never to very great values for the more inaccessible timber.

Since the carrying costs of stumpage when combined with compound interest cause it to increase very rapidly in theoretical capitalization, it appears hopeless to realize any high interest rate on stumpage now valued at $\$ 1.50$ to $\$ 3$, much of which probably will have to be held from 30 to 60 years. In the course of this investigation several lumbermen said that their stumpage had cost them $\$ 1.50$ to $\$ 2$ a thousand, that at the present rate of cutting it would last 50 to 60 years, and that they expected to realize 6 to 8 per cent compound interest on the investment. In order to secure any such profit, stumpage values must go to a price which there is slight hope of realizing. Figure 14 (Appendix) gives data on this point. These men have figured from the wrong end. A more logical way is to determine the approximate length of time required to remove the stumpage, to estimate as closely as possible-which is largely guess-work at best-the prices that stumpage will bring during the process of removal, and then calculate the interest which may be earned. Several lumbermen who have studied the stumpage situation carefully have come to the conclusion that generally speaking, there will be no large profits in the future, and that stumpage owners will have to be satisfied with a moderate rate of increase.

Figure 3 shows certain relations which have already been mentioned. It indicates the movement of the average annual price at which sales have been made, so far as information has been secured; and it shows the probable average going price of stumpage, taking into account the data available and also a large number of sales of individual claims for which exact information is not available. Taking January 1,1904 , as the average date of purchase of private stumpage and 77 cents as the averprice, it shows (1) the increasing cost of stumpage due to the annual outlay for taxes, protection, and administration, (2) the cost capitalized with compound interest at 3 per cent, and (3) the cost capitalized with compound interest at 6 per cent. This figure shows that the average original cost plus 6 per cent carried capitalization above the going price in 1916 .

Since 1909 stumpage has not advanced generally, and from now on there is no good reason to believe that it will advance fast enough on the average to yield an 


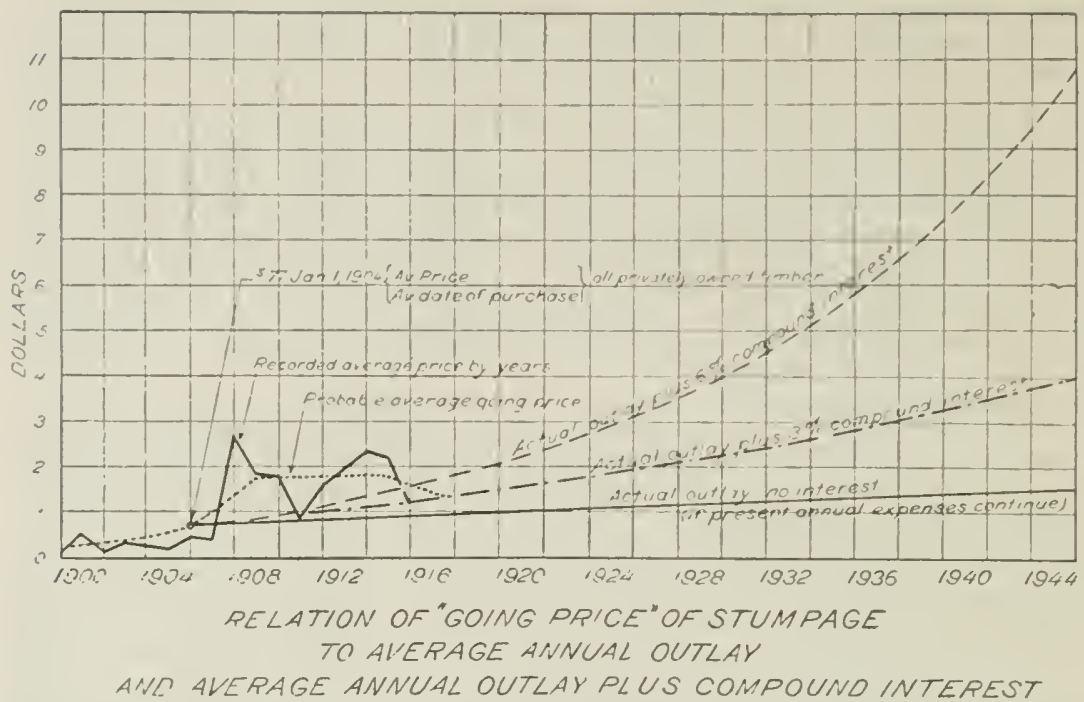

interest rate that will tempt any speculator. A saner view, widely held, of the possibilities of stumpage as an investment should make for greater stability in the lumber industry.

\section{THE DISPOSAL OF CUT-OVER LAND}

It is estimated that in the past 60 years about $3,000,000$ acres of timber land have been cut over in the Inland Empire. Of this probably 75 per cent is suitable for agriculture, and a large part has been or is being put to agricultural use. There is left about 750,000 acres best suited to the growing of timber. Much of this is still held by the lumber companies, and a large part of it is reforesting naturally where fire has not killed the young growth. The cut-over area is heing increased at the rate of about 100,000 acres per year. The areas on which operations are now being conducted do not contain nearly so high a percentage of agricultural land as that cut over in the past.

The private owner in the past has usually had no definite policy relating to the disposal of his cut-over lands. In some cases the land is sold for grazing. In some cases it is sold for agricultural development, although sometimes held at so high a price as to prevent agricultural use. Some cutover land is held for rights of way; some for possible mineral which may be discovered; and some, perhaps, in the hope that the Government will sometime decide to take it over and manage it for the permanent production of timber crops. The main idea in the minds of lumbermen is that they wish to realize as much as possible from their cut-over land and let go of it, for none of them in the Inland Empire can yet see ary justification for a lumber company to hold its cut-over land for a second crop of timiner. Because of the rapid growth and the exceptionally high value of white pine it is felt that private owners will utlimately see the profit in raising crops of this timber where the climate is suited to growth of the species, provided that fire protection is brought to a satisfactory degree of efficiency. In the other forest types, the profits to be obtained from the practice of forestry are less promising because of the slower growth of the timber.

Investments in timberland in the Inland Empire with the object of producing continuous crops of wood can not be expected to yield rates of interest sufficiently high to attract much private capital at this time. There are considerable areas already cut over whose highest economic use will be realized by permanent management for the production of timber. Such land in growing timber will benefit the public by protecting stream flow. The public will sometine need the timber which can be produced on these areas. It is, therefore, essential to the public welf are to arrange for the permanent management of these lands for forest purposes.

Many lumbermen have already expressed themselves as favoring the adoption by the Government, State or Federal, of some definite policy for handling cut-over land, 
and will cooperate with the public in a far-sighted plan for utilizing forest land to grow successive crops of timber.

\section{THE PRODUGTIVE INDUSTRY-LOGGING, MANUFACTURING, MARKETING.}

Until about 1900 the lumber industry in the Inland Empire existed almost exclusively to supply local markets. In that year the cut was only 560 million board feet. With the development of railroad transportation, the rapid settlement of much of the territory west of the Missouri River, and the decreasing lumber cut of the Lake States, the Inland Empire found new markets. The cut expanded rapidly until in 1907 it had reached 1,400 million feet; it has grown slowly since 1907, and in 1915 was about 1,600 million feet.

A strong tendency to operate the sarmills beyond the ability of the market to absorb their product is evident. The "maximum theoretical capacity" of the larger mills is only half utilized. The capacity of the larger mills has been expanding very rapidly, while small mills have decreased greatly in number.

The yard stock carried normally at mills in the Inland Empire is exceedingly large in proportion to the annual shipments, averaging about 75 per cent. In 1914, a fairly representative year for the period immediately preceding the war, 15 per cent of the product of the Inland Empire was distributed locally, 22 per cent went to eastern MIontana, 7 per cent wcnt to Rocky Mountain States outside the Inland Empire, 35 per cent went into the Nississippi Valley west of the river, 12 per cent into the eastern part of the Mississippi Valley, 6 per cent to the Atlantic Coast, 2 per cent to Canada, and less than 0.1 of one per cent into other exports. The prosperity of the country as a whole, and especially good crop years west of the Mississippi, are reflected in the lumber shipments.

Freight rates on Inland Empire lumber average about $\$ 7.50$ per thousand feet from mill to market, thus furnishing the railroads with traffic amounting to about $\$ 12,000,000$ yearly.

The average cost of producing lumber from 1909 to 1914 was $\$ 12.23$ per thousand feet mill tally, exclusive of stumpage or interest charges. This left an average margin for stumpage and profit of \$2.62. Logging costs increased on the average about $\$ 1.00$ per thousand feet during this time. A consideration of the cost of different steps in lumber production at different mills showed a rather widespread between the highest and lowest, indicating considerable room for increased efficiency.

The industry employs about 14,000 men in the Inland Empire, the number fluctuating somewhat because of the seasonal nature of the work. Unsatisfactory labor conditions, especially in the woods, can be improved. The industry was found to be distributing about $\$ 2 \$, 000,000$ annually for wages, supplies, and freight, a sum which is exceedingly important to the general prosperity of the Inland Empire.

\section{LOGGING AND LUMBER MANUFACTURING OPERATIONS}

In the smoother parts of the Inland Empire logging is a comparatively simple process. In the rougher places, however, where much of the work is now being done and a far larger proportion must be done in the future, many different methods suited to local conditions must be used. At the present time about 35 per cent of the logging involves the use of power skidding; the remainder is done by horses. Logs are transported an average distance of 40 miles from the stump to the mill; a large part of this transportation is by railway, although stream driving is used at some stage in handling about 40 per cent of the timber. Stream driving involves on the average a loss of about 6 per cent of the logs, or a total loss in the Inland Empire of about $\$ 190,000$ yearly. The sawmill plants have nearly all been recently constructed, so that they are decidedly modern. Owing to the considerable proportion of choice woods and the long distances which they must be transported to market, lumber is highly manufactured.

\section{CURRENT WETHODS OF LOGGING.}

Approximately 80 per cent of the logging is done by the companies which manufacture the lumber. The other 20 per cent is conducted mainly by contractors who more or less directly represent the manufacturers to whom the logs are delivered. In some cases the logger contracts to deliver logs from the manufacturing company's own timber land. In other cases the logger engages to log timber purchased by the manufacturer from the Forest Service or other land owners. In some cases the logger locates a suitable piece of timber and finds a manufacturing company willing to buy logs delivered at a satisfactory price. In contrast with the open log market 
on Puget Sound, less than 2 jer rent of the logs are producerl in the Inland Eimpire without a definite purchaser in riew.

The areas now heing logged in the Inland Empire give an average cut of about 12,000 board feet per acre, log scale. The California pine comtry, more nearly romparable to the Inland Empire than any of the other prineipal producing regions of the West, cuts about 20,0)(1 feet yer acre; California redwood euts about 60,000 feet; and Coast fir from 40,000 to 50,000 feet. Not only does the quantity of timber per acre average much less in the Inland Finpire, but the individual trees are considerably smaller than in the other regions just named. White pine averages five to seven 16-foot logs to the tree, and the logs runs to 12 pieces to the thousand board feet. Western pine averages 4 to 5 logs to the tree, and about 5 logs to the thousand feet. Larch sud spruec run about the same as white pine. Douglas fir averages from 3 to 5 logs to the tree and about 10 to 15 logs to the thousand feet. Lodgepole pine runs still smaller than Douglas fir.

In the early days of the industry in the Inland limpire, plenty of timber, mostly western pine, was found on flat land handy to railways or driveable streans. This presented a very simple logging problem. "The timber, which throughout the Inland Empire is of a size easily lrandled by horses, was "skildled" (dragged on the ground) direct to the nill or to the stream, or was skidded, decked up in piles, and loaded on wheel vehicles or sleighs for hauling to the mill or stream. Now, however, owing to the greatly increased distance from the timber to the mill and to the much rougher country being logged, the transportation of the log is far more complex.

Horses can be used to skid logs, even on decidedly steep slopes. In a few places, however, the ground is too steep and "hand logging" is resorted to; here men working with cant hooks roll and slide the logs down the steep slopes to points where some better means of transportation is available. Although steam donkey engines and cable systems have been operated for many years to skid logs in California and in the Coast Fir region, only in the last few years has this form of logging come into extensive use in the Inland Empire. Now both ground and overhead steam skidding systems are increasing in use rapidly. This sort of skidding is done most advantageously in connection with a railway, but in a few cases donkeys are being used as adjuncts to stream driving. While horse skidding is feasible under almost all conditions, horses are being replaced by steam because many ingenious derices have made the latter less costly.

In order to reduce the time of transportation from stump to mill, thus reducing the investment tied up in logs, railway logging tends to replace stream driving; this also eliminates the large losses involved in water transportation. In valley bottoms too steep to permit railroad building and where conditions are not suitable to stream driving, flumes are coming into use to carry the logs to a railway or drivable stream. These flumes are $V$-shaped, with sides 40 to 60 inches high; a large quantity of timber can be "flumed" with a comparatively small volume of water.

A large part of the Inland Empire logging is now being done on rough ground, and in the future both the percentage of rough ground and the roughness of the territory logged will increase. No little engineering skill is required to select the best method of logging for a given set of conditions and to adapt it effectively to the particular "chance." Rapid progress has been made in improving methods.

Between 40 and 45 per cent of the logs produced are transported by water at one time or another in the course of their movement to the mill. Most of these logs are driven from the bank very near where they are cut direct to the mill; in a few cases they are transported part way by rail and then driven to the mill; and in other cases they are driven for a considerable distance and then loaded on cars for shipment to the mill. With all of these methods the logs are subject to the losses which customarily take place through sinkage and strayage in driving.

Data available on slightly more than a billion feet of logs handled by companies which drive much of their timber indicate a loss in driving of approximately 6 per cent. These are companies which no doubt suffer the heaviest losses in driving, owing to the conditions under which they operate Noreover, this figure covers all losses from the time the logs are scaled in the woods until they are rescaled at the mill, including the sinling of heavy logs and the strayage of other logs into sloughs, meadows, ete., in time of high water, ducking under booms, breakage in dynamiting jams and going over falls, breakage in chuting, unloading from trains, etc.; so that, on the whole, 6 per cent for these particular companies is believed to be slightly high for the driving loss alone. Probably it is fair to assume that the shrinkage in log scale between the woods and the mill in the Inland Empire is approximately 6 per cent of the 40 per cent of the cut which is driven. With an annual cut of 1.33 billion feet, $\log$ scale, this shrinkage would approximate 32 million feet. If the logs have an average value of $\$ 6$ per thousand feet, a money loss of about $\$ 190,000$ is involved, 
which is mainly due to the loss in driving. This loss is accounted for as part of the cost of logging.

\section{MILL OPERATION.}

The milling plants in the Inland Empire are generally up-to-date. This is true because the Inland Empire has developed more recently than any of the other important lumber producing regions, and because the degree of manufacture is higher than in most other regions. The two most important species in the Inland Empire, western pine and white pine, together including about 65 per cent of the cut, are especially valuable. They are graded more closely and manufactured more highly than most other species. Furthermore, owing to the long distance the product has to be transported to market it is usually found profitable to manufacture as highly as practicable before shipment in order to reduce shipping weight. Very little of the product is manufactured into final form in the Inland Empire, however; that is to say, less of the lumber is manufactured into doors, window sash, etc., or even into cut-up stock ready for manufacture at an Eastern mill into doors, etc., than is the case in California.

In the Inland Empire there are about 65 individual plants (more than one sometimes owned by the same company) each of which cuts on the average more than 5 million feet of lumber each year. The smallest of these plants is usually equipped with one band head saw; the largest plant has four band head saws and one gang saw. A single band saw (constructed with teeth on one edge) does not cut lumber as rapidly as does the double band with two cutting edges. It is generally considered, however, that the better quality of sawing done by the single band more than off sets the greater product of the double band. A single band ordinarily cuts from 50 to 60 thousand feet of lumber in one ten hour shift. The mills of the Inland Empire, cutting over 5 million feet each annually, may be roughly classified as to size as follows: 30 one band mills, 25 two band mills, 10 mills with 3 bands or more. In this classification a gang saw or a resaw is considered the equivalent of a band saw. The mill with two single band head saws, which is the characteristic size for mills cutting over 5 million feet yearly, cuts about 120 thousand board feet per ten hour shift, 240 thousand board feet per day of two shifts, 6 million feet per month of 25 double shift days, and 60 million feet per 10 month year. This is theoretically possible, but in practice is not accomplished. This point is discussed further in connection with capacity.

The process of lumber manufacture in the Inland Empire is in most respects similar to that employed in other important lumber regions. It has been studied more by lumbermen and it has reached a higher stage of development than has logging. Still the mill work is not so thoroughly standard as it can be made. This is indicated by the large differences in the cost of performing the same operation, which are shown in Table 7.

\section{GRADES OF LUMBER PRODUCED.}

For the important species of the Inland Empire, Table 21 (Appendix) shows that approximately the following per cents of the various grades were shipped during 1915. The proportion of the grades shipped is not always the same as the proportion of the grades produced, owing to the varying market demands, still they give a fair idea of the average product of the various species cut. White pine consists of about 84 per cent common lumber, 14 per cent select lumber, and 2 per cent shop lumber; the common which is produced in 5 grades, runs 12 per cent number one, 29 per cent two, 26 per cent three, 12 per cent four, 2 per cent five, and 3 per cent miscellaneous common (total 84 per cent). The select lumber is used principally for finishing purposes and is comparatively clear. Common lumber, in the form of inch boards, is more or less knotty, and is used as boards principally in constructing houses, barns, fences, boxes, etc. The characteristics of common lumber are roughly as follows: number one common contains small tight knots; number two has larger tight knots; number three, still larger knots which may be more or less loose; number four is extremely coarse knotted, has some small rotten spots, and is more or less checked; number five common is still more defective. Shop lumber has large knots generally, which may be loose but are so distributed that clear "cuttings" for door, window sash, and pattern stock may be obtained between them. White pine is the most highly prized general use lumber known, owing principally to the ease with which it is worked, its lightness, and its fine, even texture. Properly seasoned and planed, it averages about 1900 pounds per thousand board feet.

Western pine runs about 10 per cent select, 68 per cent common, and 22 per cent shop. The five grades of common run .4 per cent number one, 19 per cent two, 39 per cent three, 8 per cent four, .3 per cent five, and 1 per cent of miscellaneous common. The uses and qualities of the grades of western pine are very similar to those of white 
pine. Western pine is not quite so soft and light as white pine, but approaches it so closely that it frequently goes under the trade name of "white pine." It weighs about 2100 pounds per thousand feet.

Douglas fir and larch, which are classed and handled together on account of their similar qualities, run about 3 per cent select, 21 per cent common, and 76 per cent dimension lumber, timbers, and ties. The common lumber averages about 3 per cent number one and two, 14 per cent three, and 4 per cent four. The dimension lumber and timbers are used for frames of buildings, mine timbers, and the like. These species are considerably harder and heavier than the pines, and so are less desirable for general building purposes. Their weight, about 2300 pounds per thousand board feet, limits the distance to which they can be profitably shipped.

The species already named constitute over 90 per cent of the cut in the Inland Empire; in addition small amounts of white fir, cedar, and spruce are produced. The white fir all goes into common lumber, running 92 per cent number three and better and 8 per cent of four and five. Its principal good point is that it is about as light as white pine, but it is not so soft. The cedar runs 3 per cent of select and 97 per cent of common lumber. It has the advantage of being the lightest of any of the Inland Empire woods, weighing only 1600 pounds per thousand board feet. It is produced in such small quantities, however, that a demand for it is not readily developed in distant markets. Spruce runs 1 per cent select and $\$ 9$ per cent common.

\section{THE VOLUME OF LUABER PRODUCED.}

The cut of lumber in the Inland Empire in 1900 amounted to 560 million board feet. By 1907 it had nearly reached 1,400 million feet. Since that time the increase has been less rapid; in 1915 the cut as 1,642 million feet, or about 5.3 per cent of the total sof twood production of the United States. In 1900 the cut of western pine was 76 per cent of the total, while white pine was less than 2 per cent; by 1915 the cut of western pine had declined to slightly less than 40 per cent and white pine liad increased to 25 per cent.

The total cut of the Inland Empire in 1880 was probably less than 100 million feet. In 1890 the cut was probably under 300 million feet. From 1507 to 1915 , inclusive, it has varied between 1,375 and 1,705 million feet, reaching the maximum $(1,705)$ in 1910 (see figure 4). Figure 4 shows also the variation in the cut of principal species, which is brought out further by figure 15 (Appendix). Table 4 gives the cut by principal species and by States in 1915. Table 22 (Appendix) shows the cut for the year 1900 and from 1905 to 1914 inclusive. Table 17 (Appendix), showing the cut by species for various parts of the Inland Empire in 1912, brings out clearly that white pine, white fir, hemlock, and cedar are cut principally in north Idaho; and that the cut of eastern Oregon consists principally of western pine.

The cut in western Wyoming has been omitted from these tables, since it amounts to only about $1 \frac{1}{2}$ million feet annually. The cut for Montana includes that east of the Continental Divide, which it was impracticable to segregate. This also is a comparatively negligible amount, averaging less than 10 million feet yearly. The cut of Douglas fir, cedar, and spruce in the portions of Washington and Oregon included in the Inland Empire is estimated. The other data are based on census figures.

Table 23 (Appendix), based on identical mills, shows a decrease in cut from 1914 to 1915 , in Montana and Idaho combined, of about 2.5 per cent. A decrease of 3.8 per cent in the entire Inland Empire from 1913 to 1914 is indicated by Table 22 (Appendix). These decreases are undoubtedly due to market conditions. 1916 shows an increased cut over 1915. (See Table 24, Appendix.)

Figures 4 and 15 (Appendix) show the production of various species by years in the Inland Empire. The cut of western pine in $1907 \mathrm{w}$ as 789 million feet; it dropped off in 1908, but rose to 870 million feet in 1910; from 1911 to 1915 inclusive it fluctuated between 600 and 700 million feet. One reason for the decline since 1910 is that western pine occurs at the lower elevations and is generally the most accessible class of timber. A large quantity of this species was logged in the early years. Much of the accessible supply was exhausted and cutting extended into the higher and less accessible areas, which contained more of the other species. Furthermore, the tendency has been to increase the cutting of white pine, which has a higher selling price. However, the construction of new mills in southern Idaho and in the Deschutes region (regions of slight manufacturing development heretofore) will probably increase materially the cut of western pine.

The cut of white pine increased from 116 million feet in 1905 to 419 million feet in 1915. White pine is second in importance of the species produced. Larch rose from a cut of 75 million feet in 1905 to 317 million feet in 1913. The production of this species fell off to 243 million feet in 1914 owing to the poor market and the resulting tendency to leave larch in the woods. Douglas fir, the wood next in importance, 
increased from a cut of 79 million feet in 1905 to 209 million in 1915 . Figure 15 (Appendix) shows the percentage of each species cut in the Inland Empire and brings out clearly the decline of western pine and rise of white pine in importance.

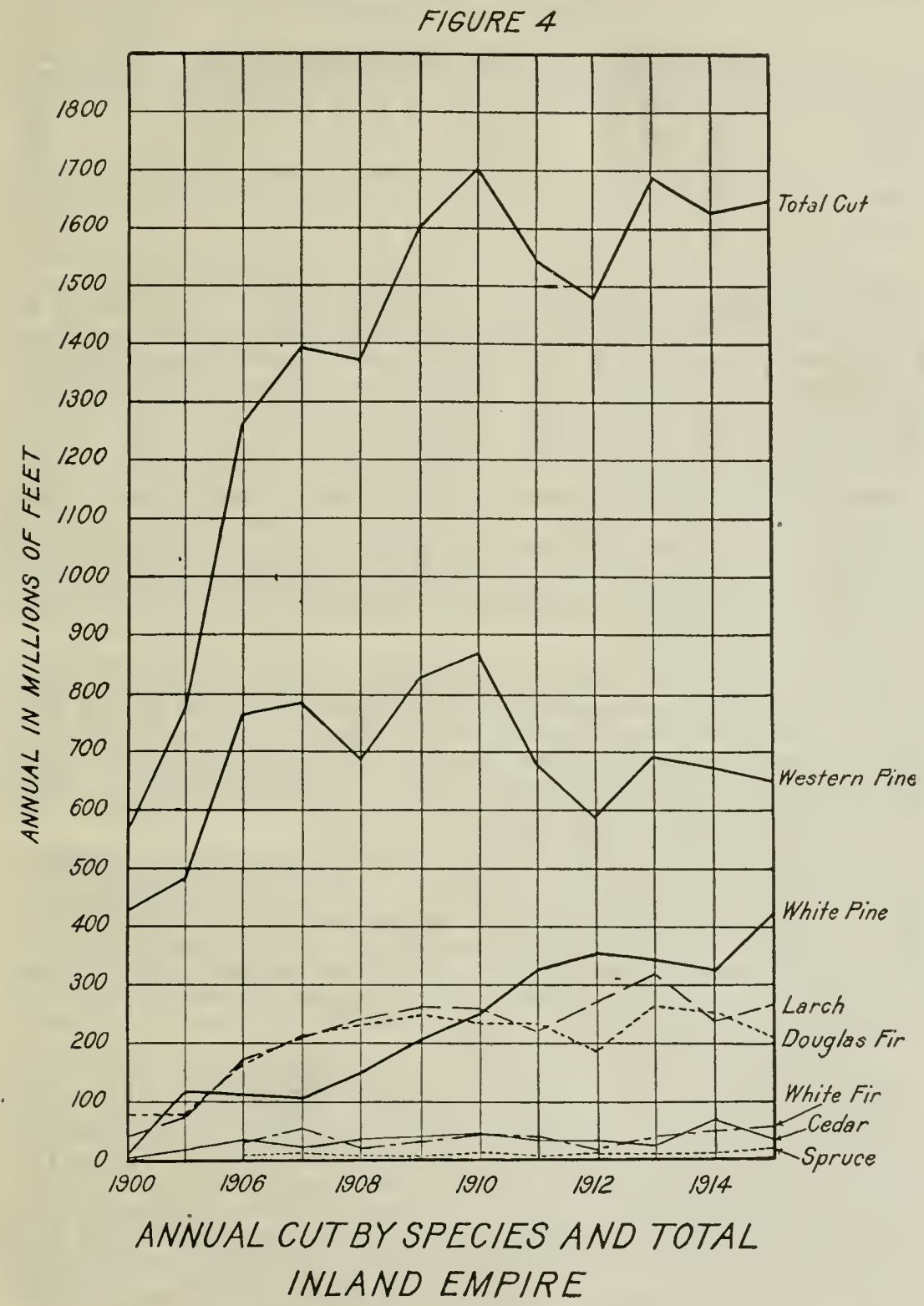


TABLE 4-Softuood lumber cut in the Inland Empire in 1915, by species and States, based on Forest Service dala.

(Millions of fect, board measure.]

\begin{tabular}{|c|c|c|c|c|c|c|c|c|c|c|}
\hline State & $\begin{array}{c}\text { Western } \\
\text { pine }\end{array}$ & $\begin{array}{l}\text { White } \\
\text { pine }\end{array}$ & $\begin{array}{c}\text { Douglas } \\
\mathrm{fir}\end{array}$ & Larch & $\begin{array}{c}\text { White } \\
\text { fir }\end{array}$ & Spruce & Cedar & $\begin{array}{l}\text { Hem- } \\
\text { lock }\end{array}$ & $\begin{array}{l}\text { I odge- } \\
\text { pole } \\
\text { pine }\end{array}$ & $\begin{array}{l}\text { Total } \\
\text { soft- } \\
\text { woods }\end{array}$ \\
\hline $\begin{array}{l}\text { Idaho .............. } \\
\text { Montana........... } \\
\text { Oregon............ } \\
\text { Washington ....... }\end{array}$ & & $\begin{array}{r}302 \\
27 \\
90\end{array}$ & $\begin{array}{l}76 \\
41 \\
42 \\
50\end{array}$ & $\begin{array}{r}111 \\
115 \\
16 \\
21\end{array}$ & $\begin{array}{r}43 \\
7 \\
1 \\
1\end{array}$ & $\begin{array}{r}3 \\
13 \\
\ldots .6\end{array}$ & $\begin{array}{l}30 \\
i \\
1\end{array}$ & $\begin{array}{r}1 \\
1 \\
\ldots .1\end{array}$ & $\begin{array}{l}1 \\
2\end{array}$ & $\begin{array}{l}769 \\
324 \\
239 \\
310\end{array}$ \\
\hline Total. & 648 & 419 & 209 & 263 & 51 & 16 & 32 & 1 & 3 & 1,642 \\
\hline Per cent of total.... & 39.5 & 25.5 & 12.7 & 16.0 & 3.1 & 1.0 & 1.8 & .1 & .2 & 100.0 \\
\hline
\end{tabular}

While white pine is the most highly prized species in the Inland Empire, there is perhaps a tendency to give it more prominence than is due. As indicated in the tables showing the stand, only about 8 per cent of the timber in the Inland Empire is white pine, whereas about 38 per cent of the stand, or nearly 5 times as much, is western pine. The white pine cut of the Inland Empire, approximately 420 million feet in 1915, does not make up a very large portion of the cut of this species in the whole United States. Census figures for 1913 give the total cut of white pine as approximately 2.5 billion feet, so that the Inland Empirc cut in that year was only about 13 per cent of the total. According to 1913 census data the whitc pine cut for Michigan, Wisconsin, and Minnesota was approximately 1.4 billion feet (including approximately 50 per cent of Norway pine). The cut of white pine in New England in 1913 was 541 million feet, and when New England is combined with New York and Pennsylvania, the white pine cut of the Northeastern States is approximately 700 million feet; and 90 million feet is cut in the Southern Appalachians. The total stand of white pine in the United States is estimated at 53 billion feet, of which about 40 per cent is in the Inland Empire.

The total cut of western pine in the United States, as shown by the 1913 census, was about 1.25 billion feet, of which the Inland Empire produced 695 million feet or 56 per cent. California produced the next largest quantity, with 25 per cent of the total. Comparatively small quantities were produced by Arizona, New Mexico, Colorado, South Dakota, Utah, and Wyoming. The species has never received proper recognition in the eastern markets, where it competes principally with white pine, which is only slightly superior to the western pine but is much more highly prized because of its long standing with users of lumber.

It is now the custom in California and to some extent in the Inland Empire to give western pine the trade name of "white pine." This is considered unfortunate, since there is an enormous amount of western pine to be marketed and it can best be done in the long run under its own name. A clistinctive trade name, like western pine, with full knowledge of the high qualities of the wood, should be brought to the attention of users of forest products. The Inland Empire is selling far more western pine than white pine. With a certainty of a largely increased cut of western pine in the near future, a determined effort should be made to put its marketing definitely and permanently on its own feet.

Another important species in the Inland Empire which has as yet received little consideration is larch. There is about 20 per cent more larch than white pine in the Inland Empire. So far it has been considered a decidedly inferior species. Although it possesses some serious drawbacks, owing to its weight and difficulty in drying, it has a beautiful grain for finishing purposes and is suitable for many highgrade structural uses. It is much superior to the tamarack of the Lake States. A European timber expert in the region not long ago stated that while the European larch is their most highly prized coniferous wood, he believes that the larch of the Inland Empire has still greater possibilities. Most of the larch in the United States is in the Inland Empire. The stand is approximately 26 billion feet. This species should also receive a more aggressive exploitation in the market. Experiments by the Forest Service have demonstrated methods of drying larch which greatly reduce the loss ordinarily occurring in its seasoning.

Figure 5 shows the relation between cut and shipments by members of the Western Pine Manufacturers' Association and the Montana Larch and Pine Manufacturers' Association for the period from 1905 to 1914 . The cut of one year ordinarily has a direct relation to the shipments of the preceding ycar. If the shipments are light, the cut is generally reduced to prevent overstocking; or if the shipments are unusually heavy, the cut is increased in anticipation of a continued good market and also 
to make up depleted stocks. The cut and shipments of the Montana Larch and Pine Association show even a closer relation than do those of the Western Pine Manufacturers' Association.

\section{PRESSURE FOR PRODUCTION.}

Pressure to cut is felt not only as a feature of stumpage ownership but also in connection with lumber manufacture. This is against the interests of the manufacturer from a market point of view. But an operator with an organization in good

FIGURE 5

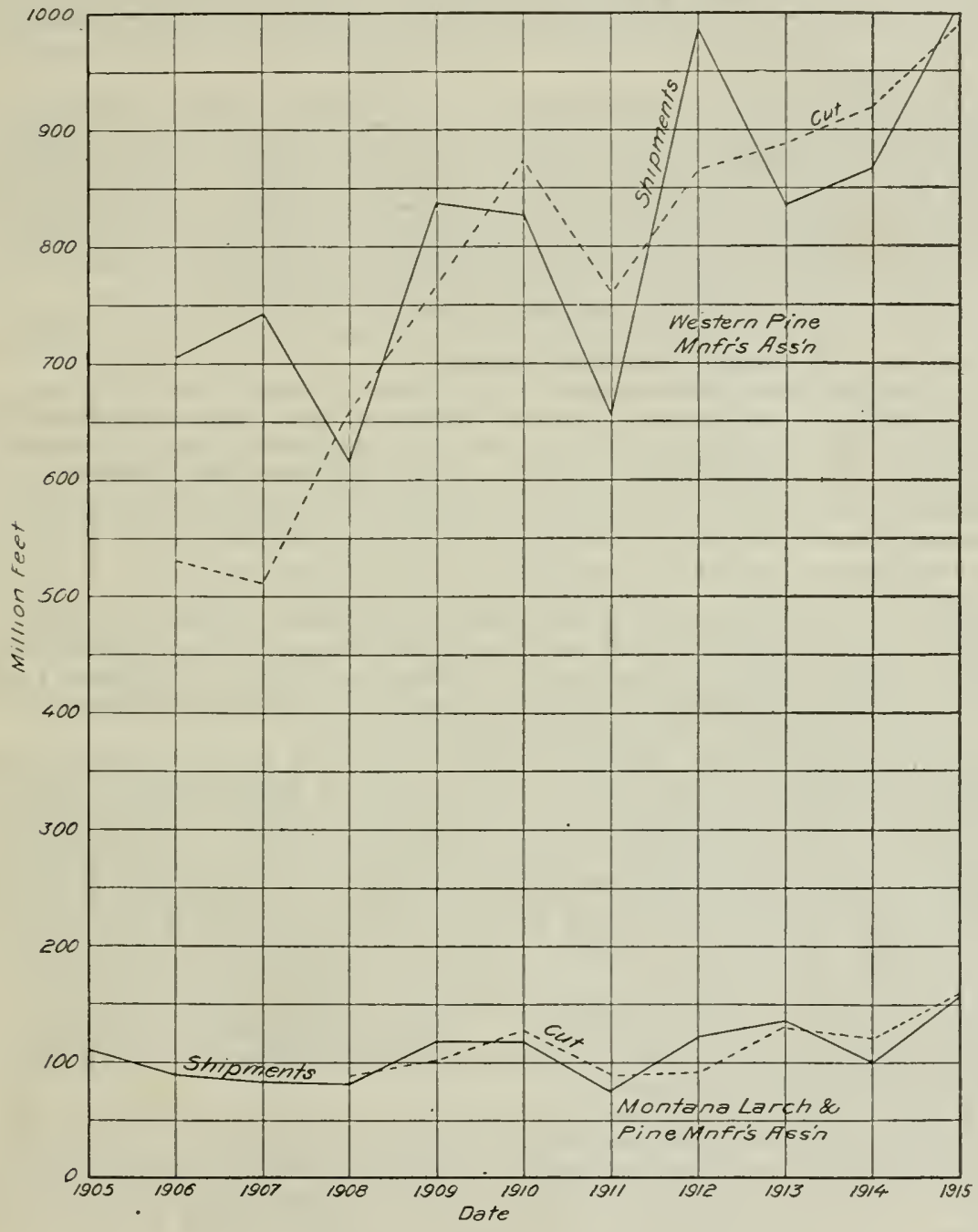

INLAND EMPIRE-CONPARISON OF YEARLY CUT AND SHIPMENTS OF LUMBER

working order to produce a given quantity is very loath to reduce the output and destray his organization, wholly or in part. He wishes to keep the investment in his plant productive, which can be done only"through the continuous manufacture of lumber. He also generally wishes to realize, or finds it absolutely necessary to realize, on the investment in order to meet obligations of various sorts; overhead expenses for management, insurance, taxes, etc., go on regardless of operation, thus creating a strong desire to cut at full capacity in order to hold down overhead costs 
per unit of product. The management also usually takes a real interest in the welfare of the community dependent for its living upon the running of the plant. Though it may barely be coming out even, or may be losing some money, a fecling of responsibility for the maintenance of the community tends to kecp up cutting.

\section{SAWMILL CAPACITY.}

The sawmill capacity of the Inland Empire is far from being fully utilized; only 47 per cent of the "maximum theoretical capacity" of the larger mills was used in 1914 ; the capacity of small mills was even less fully utilized. The capacity in large mills has been developed very largely since 1905 , with large plants rapidly replacing small ones. Indications are that the large mill capacity will continue to develop in the immediate future.

The 55 larger mills, each of which cuts over 5 million feet annually, cut al together about 1,290 million feet in 1914, or about 86 per cent of the total cut. The cut of these 55 mills in 1914 was 1,192 million fect. Few of them, however, cut all that they could if operated to full installed capacity throughout the year. The "maximum theoretical capacity" is based on a maximum possible length of cutting season at each plant, taking into account climatic conditions at the mill site, the feasibility of obtaining logs, the equipment of the mill and the cut normally produced by it in two 10-hour shifts 6 days per week throughout the cutting season.

The 55 mills had in 1914 a maximum theoretical capacity of 2,520 million feet annually, so that on the average the group was used in that year to approximately 47 per cent of its maximum theoretical capacity. ${ }^{1}$

It must be clearly understood that the companies owning these mills could not attain the "maximum theoretical capacity" without extensive improvements in mill equipment, increased logging facilities, more working capital, etc. Furthermore, the market conditions and "good times" which would encourage running to full capacity automatically limit the labor available, and thus tend to prevent capacity operations. This was true during a considerable part of 1916. Several large plants constructed since 1914 have materially increased the capacity.

There has been a steady tendency for small mills to go out of business. The total cut of the Inland Empire has not been increasing nearly so fast as the cut of the larger mills. Small mills going out of existence have had their places taken by large mills. In 1910 there was a total cut in the Inland Empire of about 1,705 million feet; the larger mills, each cutting over 5 million feet annually, cut about 1,020 million feet, leaving 685 million feet cut by small mills. Similarly 475 million feet was cut by small mills in 1913 , and 390 million feet in 1914.

When, during the last 5 years of the last century, the lumber industry in the Inland Empire began to develop as a producing region shipping lumber into the Mississippi Valley, the cut was very largely by small mills. These mills were usually set close to the railroad and in the edge of a body of timber. They prospered more or less; at least the number of them was considerable, especially from 1905 to 1909, when the lumber industry was most profitable in the Inland Empire. Since 1910 the number of small mills has diminished rapidly, although there still existed a considerable number in 1912. They dropped off nearly one-third in number from January, 1912, to January, 1913, but there was a slight increase in 1914. This is shown by Table 24 (Appendix), which gives the total number of active mills and the lumber cut in each year from 1906 to 1917 , inclusive, for the states of California, Oregon, Washington, Idaho, and Montana. This table shows the period of greatest activity of small mills. In each of the States a decreasing number of mills is shown after 1909, while the cut increased.

Table 25 (Appendix) gives the number of mills of various sizes operating in each of these States in 1914. It shows, for instance, that in Idaho 25 mills, each cutting over 5 million feet yearly and representing 18 per cent of all the mills in the State, cut 89 per cent of its total lumber output. Table 26 (Appendix) gives the number of mills of various classes active in different parts of the Inland Empire in 1914; at the bottom of this table the decrease in the number of small mills and the increase in the number of large mills from 1912 to 1914 are indicated.

The principal reason for the rapid decrease in the number of small mills was the decreasing accessibility of the timber, which made necessary much larger logging investments than formerly, and the hard times in the industry which forced small operators out of business. Furthermore, the local markets which many of the small

In the summary report on the lumber industry, the "maximum installed capacity" of the Inland Empire is stated at approximately 3.5 billion feet. This, however, includes small mills and is determined in a somewhat different way from the "maximum theoretical capacity." See "Some Public and Economic Aspects of the lumber industry," by W. B. Greeley. 
mills formerly supplied have been made accessible to larger mills through railroad development.

The nature of a small mill business is such that it usually goes out of existence without causing any considerable financial disturbance. The investment is small and usually entirely owned by one man. When things are not going profitably he can quit of his own accord; or the sheriff may force the issue. When times become hard with large companies, however, a much greater struggle to stay in existence is possible and is actually made, owing to the larger number of people who have invested and whose resources are available to nurse the enterprise through what is hoped to be only a temporary depression. Bankers and other creditors also exert themselves to help the larger enterprises stay on its feet as long as practicable. In recent years the struggle has been severe for many of the larger operators, and by no means successful on the part of all of them.

With the decreasing accessibility of the standing timber in the future, it seems probable that the proportion of the cut turned out by small mills will continue to decrease. Usually the small, portable type of mill with a rotary saw is decidedly less efficient than the larger modern band mill. The small mill usually produces poorly manufactured lumber and lacks proper facilities for handling it; the waste is considerable; it is apt to saw but one class of products, such as railroad ties, thus failing to utilize timber qualities to the best advantage; and it usually has very poor selling arrangements, so that of ten it cannot get a living price for its product. Of course there will always be small bodies of timber which can be most economically handled by the portable mill. This is especially true where the market is local and consumes only a small quantity of material each year.

There appear to be three broad stages in the economic development of a forest region. First, the country is settled up in advance of railway development; small mills spring up here and there to supply local needs; lack of transportation facilities make it impossible to ship lumber in or out. In the second stage, transportation is developed, and large mills with their many economic advantages tend to replace the small plant. These large mills remove the bulk of the virgin timber. In the third stage, the virgin timber is largely gone, but small areas remain here and there and stands of second growth have reached saw log size. These bodies of timber do not justify the running of large mills, and can be handled more economically by small units.

The Inland Empire as a whole is emerging from the first into the second stage, which will last for many years. The Lake States, the South and the North East are in or are rapidly approaching the third stage. It must be understood that these three phases merely indicate general tendencies. The second phase in the Inland Empire, even when well advanced, will by no means eliminate the small mill, for there are many small bodies of virgin timber here and there, inferior species left on culled lands, and moderate sized areas of second growth, which can best be handled by the small, mobile plant with its limited investment. Similarly, the small logging contractor will hold his place. In the third stage, however, where water or other cheap transportation make it feasible, some of the larger mills remain in operation. Where the general market is to be supplied and a sufficient quantity of timber is available, a single band mill with an average cut of from 50 to 60 thousand feet per ten-hour shift is regarded as the minimum size for a thoroughly efficient plant. It is a serious question, however, whether such an operation is ordinarily efficient from the marketing point of view.

Table 27 (Appendix), showing the average number of shifts operated per year by various sizes of mills in different regions of the Inland Empire in 1912, indicates that the number of shifts operated steadily increases with the size of the plant. Some consideration must be given to the fact that the position of a given mill in the classification depends upon the number of shifts operated. In general, however, this table brings out the irregular operation of the smaller plants. Even at the largest mills the average number of shifts operated is scarcely more than enough to equal one shift per day for a reasonable number of working days in the year. To permit comparison similar figures are given in the table for other regions.

\section{YARD STOCKS.}

The Inland Empire sawmills carry very large quantities of lumber in yard stocks. The average quantity on hand is 78 per cent of annual shipments; and the minimum stock, about April 30 each year, is 66 per cent of the annual shipments. The stock is turned over on the average 1.3 times each year.

Inventories of the yard stocks on hand at the various sawmills are ordinarily taken as of December 31 each year. A few mills take inventories more frequently. The production of lumber at mills in the Inland Empire runs somewhat as follows. There is very little sawing during January and February, owing to climatic condi- 
tions. During March there is eut about one-third of the quantity ordinarily produced during one of the summer months; during April two-thirds is cut; during May, June, July, August, September, and October the mills are generally running as near

\section{Millions of FeetperMonth}

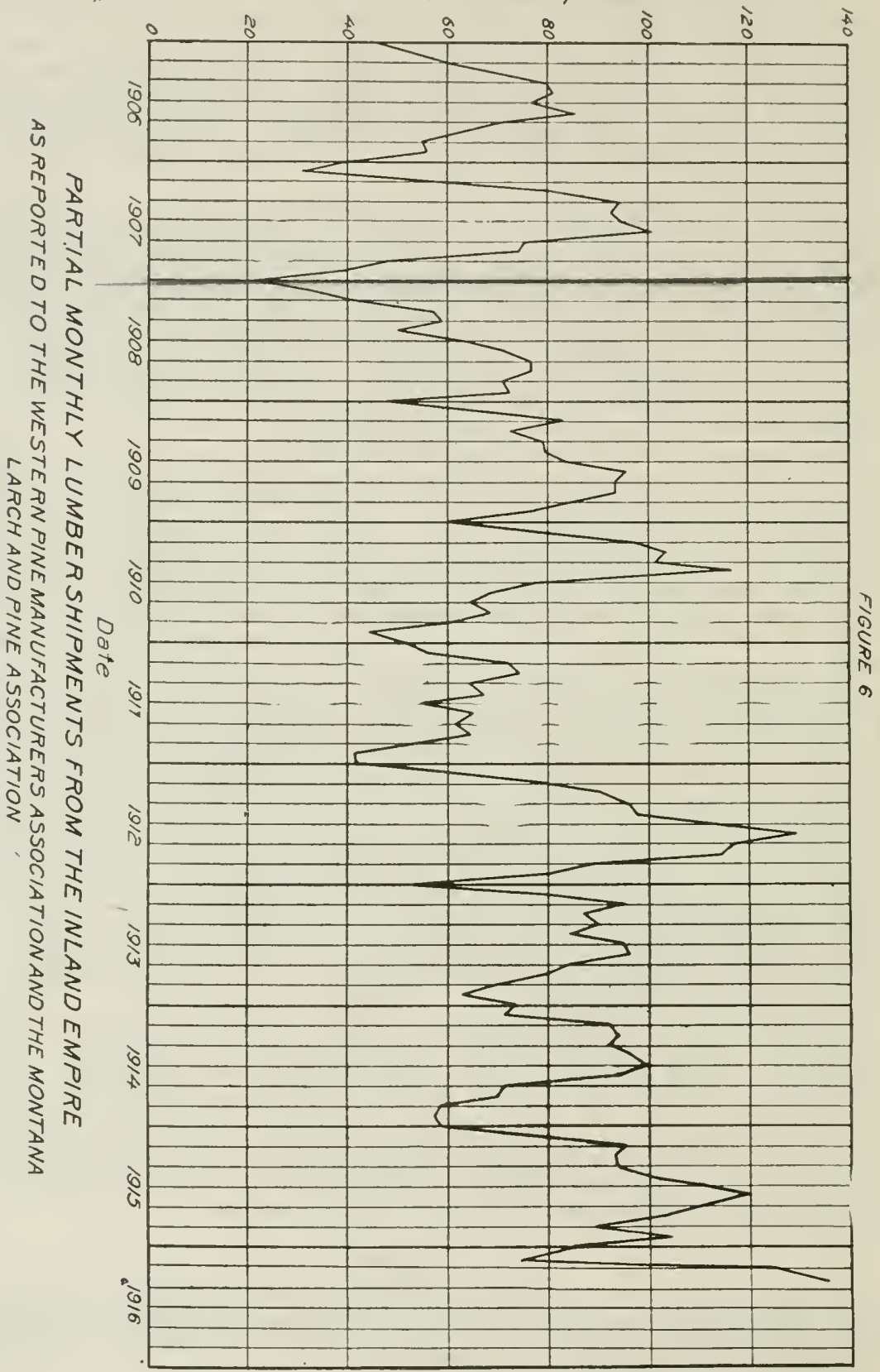

eapacity as they intend to run during the year; in November the eut drops down to about two-thirds of the normal for the busy months, and in December to one-third; it diminishes to nearly a complete shut down by the first of January. 


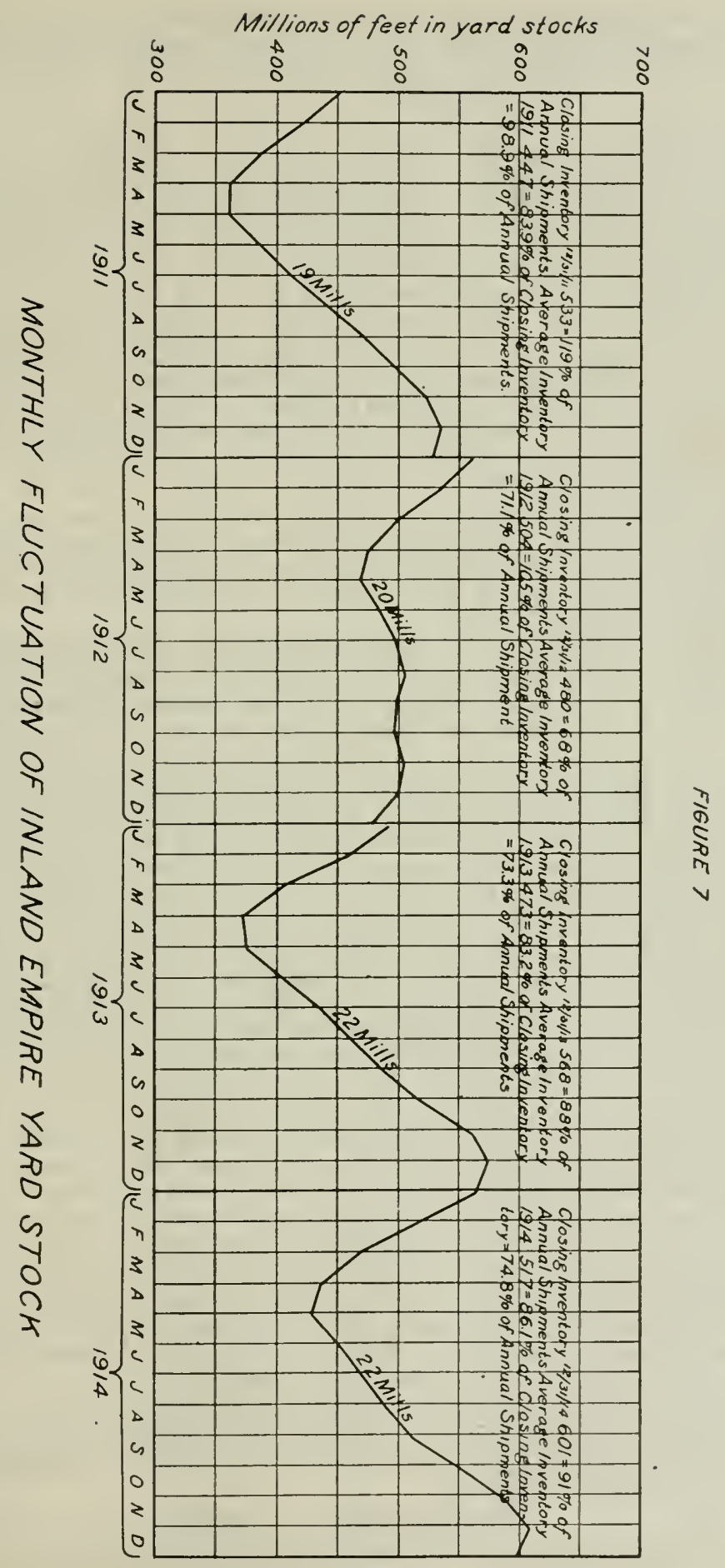


During 1915 the sawing of lumber was distributed among the months as follows expressed in percentage of the total cut. The figures are based upon approximately two-thirds of the production in the Inland Empire for the year. The percentages run: January, 1.5; February, 1.9; March, 5.1; April, 8.6; May, 11.1; June, 12.0 July, 12.2; August, 11.9; September, 11.7; October, 10.9; November, 8.1; and December, 5.0.

During the milling season enough lumber must be eut to keep the yard stocks in satisfactory condition throughout the year, so that shipping may go on in accorclance with demand as it usually oecurs. The usual demand for lumber, as is shown by the monthly shipment curve, figure 6 , is lowest about the first of January and greatest in midsummer. This change conforms somewhat with the cut. Figure 7 , based on slightly less than one-half of the production of the Inland Empire, shows the condition of yard stocks at the mills from January 1, 1911, to January 1, 1915. It indicates that the maximum stock is generally on hand December 1 , and from that time on stocks decrease until about the first of May. Then the stock inereases until it again reaches the maximum level about December 1 . Of course, this varies somewhat from year to year, depending upon the rate of cutting and the rate of shipments. Generally speaking, however, as is shown by Table 28 (Appendix) the December 31 inventory is 83 per cent of the annual cut and 88 per cent of the annual shipments. There is a discrepancy here between annual cut and annual shipments, owing to certain losses which have taken place, especially from fire at certain mill yards and local use around the plants.

The December 31 inventory is above the average for the year; the latter amounts to 78 per cent of the total annual shipments, while the former represents 88 per cent. The average minimum yard stock at any one time during the year, about April 30 , is approximately 85 per cent of the average stock on hand and 66 per cent of the average shipments during the year.

The average yard stock on hand in the Inland Empire is greater in proportion to annual shipments than in most of the other lumber producing regions in the United States. The reason for this situation as compared with Coast fir, for instance, is that a larger part of the latter is shipped green from the saw in offshore cargoes, or is kiln-dried and shipped soon after by rail, so that only about 25 per cent is kept in stock. (See Table 25, Appendix.) In California a comparatively large percentage of the timber is kiln-dried and therefore ready for shipment at an earlier date; Table 25 (Appendix) indicates that in California the inventory averages about 50 per cent of the average shipments. In the South a large proportion of the cut is kiln-dried. In the Inland Empire, on the other hand, probably less than 10 per cent of the lumber is kiln-dried, and air seasoning requires from 3 to 4 months. In the summer, the period of largest shipments, the yard stock cut during the same year is for the most part not yet dry. The elimate of the Inland Empire forces an uneven distribution of logging and milling operations throughout the year; furthermore, the lumber is highly manufactured and sorted into a large number of species, grades, and sizes (over 500 in all), so that a large quantity must be kept in stock to fill orders. Table 25 gives data for 1914 on the ratio of yard stocks to the cut at mills of various sizes. In Idaho the stock of the mills cutting less then 500 thousand feet annually is only 17 per cent of the cut. This percentage increases with the size of the mills; mills cutting over 10 million feet annually have a stock of 71 per cent.

This large yard stock represents at pre-war wage and price scales an average investment of about ten thousand dollars for each million feet of annual shipments. The units of production included in Table 28 (Appendix) have an approximate annual output of 30 million feet per plant. The smaller of these units require a larger ratio of stock to shipments to be able to fill orders promptly with well seasoned stock than do the larger units. Large marketing units, handling an annual output of say 500 million feet, could by a careful distribution of orders among the various plants make it possible to reduce the yard stock somewhat, thus reducing the capital required. Furthermore, it is believed that the development of better methods of seasoning, both in kilns and in the open air, will permit some reduetion in the average yard stock and also save much of the considerable loss that now takes place in the process of drying. A large yard stock is not without its advantages, however, since it acts as a reservoir in relation to fluctuating market demands.

Lumber stocks are turned over in the yards on the average 1.3 times per year. It is interesting to compare this rate of turn over with large department stores, where the stock of goods is turned over as often as 6 or 7 times a year. The heavy investment in yard stock is thus one of the points at which the lumber industry in the Inland Empire is handicapped.

\section{THE MARKETING OF LUMBER}

The Mississippi Valley is the principal market for Inland Empire lumber, absorbing 47 per cent of the production. 37 per cent is sold within the States of the Inland 
Empire itself. The remainder goes principally to other Rocky Mountain States and to the Atlantic Coast. The average freight on Inland Empire lumber to its markets is $\$ 7.50$ per thousand board feet. The average cost of selling lumber is 43 cents per thousand feet.

\section{LUMBER SHIPMENTS.}

Figure 8 shows the distribution of over 60 per cent of the shipments of Inland Empire lumber in 1914. Table 29 (Appendix) gives the same data for 1911 to 1914 inclusive. Table 29A (Appendix) gives data for later years. These figures represent merely that part of the Inland Empire output which it has been possible to trace fairly accurately. The States of the Inland Empire absorbed approximately 37 per cent of the entire cut in 1914. The proportion marketed in these four States has been rather steadily diminishing. In 1908 the mills of the Western Pine Manufacturers Association marketed 50 per cent of their cut in these states, but subsequently the proportion decreased to 30 per cent in 1915 . Coast fir has tended to take the place of Inland Empire timber in its home market, while its own product has been shipped in greater amounts to the States farther east.

A considerable part of the lumber marketed in the four Inland Empire States goes outside of the producing territory dealt with in this report. Montana east of the Continental Divide absorbs approximately 250 million feet of lumber annually from the Inland Empire output. About 70 million feet more is consumed in Butte, which is practically on the Continental Divide and over 100 miles east of the nearest mills in the producing region. It is estimated that approximately 15 per cent of the cut is consumed in the Inland Empire itself outside of southern Idaho and Butte.

In 1914, in addition to the 37 per cent marketed in the Inland Empire States, about 7 per cent of the shipments went into the other Rocky Mountain States; 35 per cent went into the Mississippi Valley west of the river; 12 per cent into the Central States east of the Mississippi River; 6 per cent to the Atlantic Coast; 2 per cent to Canada; and less than .1 per cent of one per cent to other foreign countries. During the first eight months of 1918 the distribution of shipments was as follows: Inland Empire States 28 per cent, other Rocky Mountain States 6 per cent, Mississippi Valley west of the river 33 per cent, Central States east of the Mississippi River 19 per cent, Atlantic Coast 14 per cent, Canada .01 per cent, other foreign less than .01 per cent.

Table 5 indicates the per capita consumption of Inland Empire lumber in the principal States to which it is shipped. Montana, which secures its lumber almost entirely from the Inland Empire and the Coast fir region, uses approximately 850 feet per capita annually of the Inland Empire product, and 380 feet of lumber from the Coast fir region. Compared with the per capita consumption of the entire United States, about 400 board feet annually, that of Montana, 1,237 feet in 1914, is remarkably high. This is because of the large quantity of timber used in the Butte mines and also because of the very rapid settlement of eastern Montana in recent years. Montana secures a greater proportion of its lumber from the Inland Empire than does any other State, about 70 per cent, the remainder coming from the Coast fir region. In the Dakotas, however, the situation is reversed. Of the lumber supplies drawn from the Northwest as a whole North Dakota takes 28 per cent and South Dakota 26 per cent from the Inland Empire. These States also draw on Minnesota for a small quantity of lumber; and South Dakota secures part of its supply from the Black Hills within its own boundaries. This condition is largely due to the freight rate situation.

TABLE 5-Market comparisons-Inland Empire and Coast fir.

[Based on 1914 shipments of 1,500,000 feet from the Inland Empire and 6,000,000 feet from the West Coast.]

\begin{tabular}{|c|c|c|c|c|c|c|c|}
\hline \multirow{3}{*}{ State } & \multirow{2}{*}{\multicolumn{2}{|c|}{$\begin{array}{l}\text { Population } \\
\text { in } \\
\text { thousands }\end{array}$}} & \multirow{3}{*}{$\begin{array}{c}\text { Per cent of } \\
\text { annual increase in } \\
\text { population, } \\
1910-1914 \\
\text { (Census estimate) }\end{array}$} & \multicolumn{2}{|c|}{$\begin{array}{l}\text { Inland Empire } \\
\text { lumber shipments }\end{array}$} & \multicolumn{2}{|c|}{$\begin{array}{c}\text { Coast fir } \\
\text { Iumber shipments }\end{array}$} \\
\hline & & & & \multirow{2}{*}{$\begin{array}{c}\text { Board } \\
\text { feet } \\
\text { per capita }\end{array}$} & \multirow{2}{*}{$\begin{array}{c}\text { Per cent } \\
\text { of total } \\
\text { shipments }\end{array}$} & \multirow{2}{*}{$\begin{array}{c}\text { Board } \\
\text { feet } \\
\text { per capita }\end{array}$} & \multirow{2}{*}{$\begin{array}{l}\text { Per cent } \\
\text { of total } \\
\text { shipments }\end{array}$} \\
\hline & 1910 & 1914 & & & & & \\
\hline 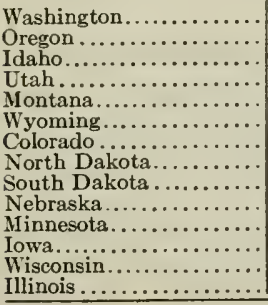 & $\begin{array}{r}1,142 \\
673 \\
326 \\
373 \\
376 \\
146 \\
799 \\
577 \\
584 \\
1,192 \\
2,076 \\
2,225 \\
2,334 \\
5,639 \\
\end{array}$ & $\begin{array}{r}1,408 \\
783 \\
395 \\
415 \\
433 \\
169 \\
910 \\
687 \\
652 \\
1,246 \\
2,214 \\
2,222 \\
2,447 \\
5,987 \\
\end{array}$ & $\begin{array}{l}5.7 \\
4.1 \\
5.3 \\
2.8 \\
3.8 \\
3.9 \\
3.5 \\
4.8 \\
3.3 \\
1.1 \\
1.7 \\
0.0 \\
1.2 \\
1.6\end{array}$ & $\begin{array}{r}55 \\
17 \\
224 \\
112 \\
856 \\
89 \\
43 \\
150 \\
136 \\
55 \\
65 \\
49 \\
30 \\
12 \\
\end{array}$ & $\begin{array}{l}5.2 \\
.9 \\
5.9 \\
3.1 \\
24.7 \\
1.0 \\
2.6 \\
6.85 \\
6.0 \\
4.6 \\
9.55 \\
7.3 \\
4.9 \\
4.7 \\
\end{array}$ & \begin{tabular}{c|}
551 \\
536 \\
306 \\
434 \\
381 \\
355 \\
165 \\
393 \\
386 \\
217 \\
121 \\
108 \\
37 \\
30 \\
\end{tabular} & $\begin{array}{l}13.0 \\
7.0 \\
2.0 \\
3.0 \\
2.75 \\
1.0 \\
2.5 \\
4.5 \\
4.25 \\
4.5 \\
4.5 \\
4.0 \\
1.5 \\
3.0 \\
\end{array}$ \\
\hline
\end{tabular}


Figure 6, showing the seasonal shipments from mills, indieates a general tendeney to small winter shipments and larger summer shipments. This graph reflects other conditions clearly. The lumber market was decidedly good in 1906, and had been improving steadily for several years. Up to about August, 1907, it was still better. Then the panic of 1907 brought a severe depression. A slow recovery through the spring and early summer of 1908 followed, which was assisted in the fall of 1908 by fairly good erops. In 1909 the erop was extraordinarily good; and after midsummer, when it was well assured, the rising eurve indicates the prosperous eondition of the farmers. With this erop to look back upon and with very rapid settlement beginning

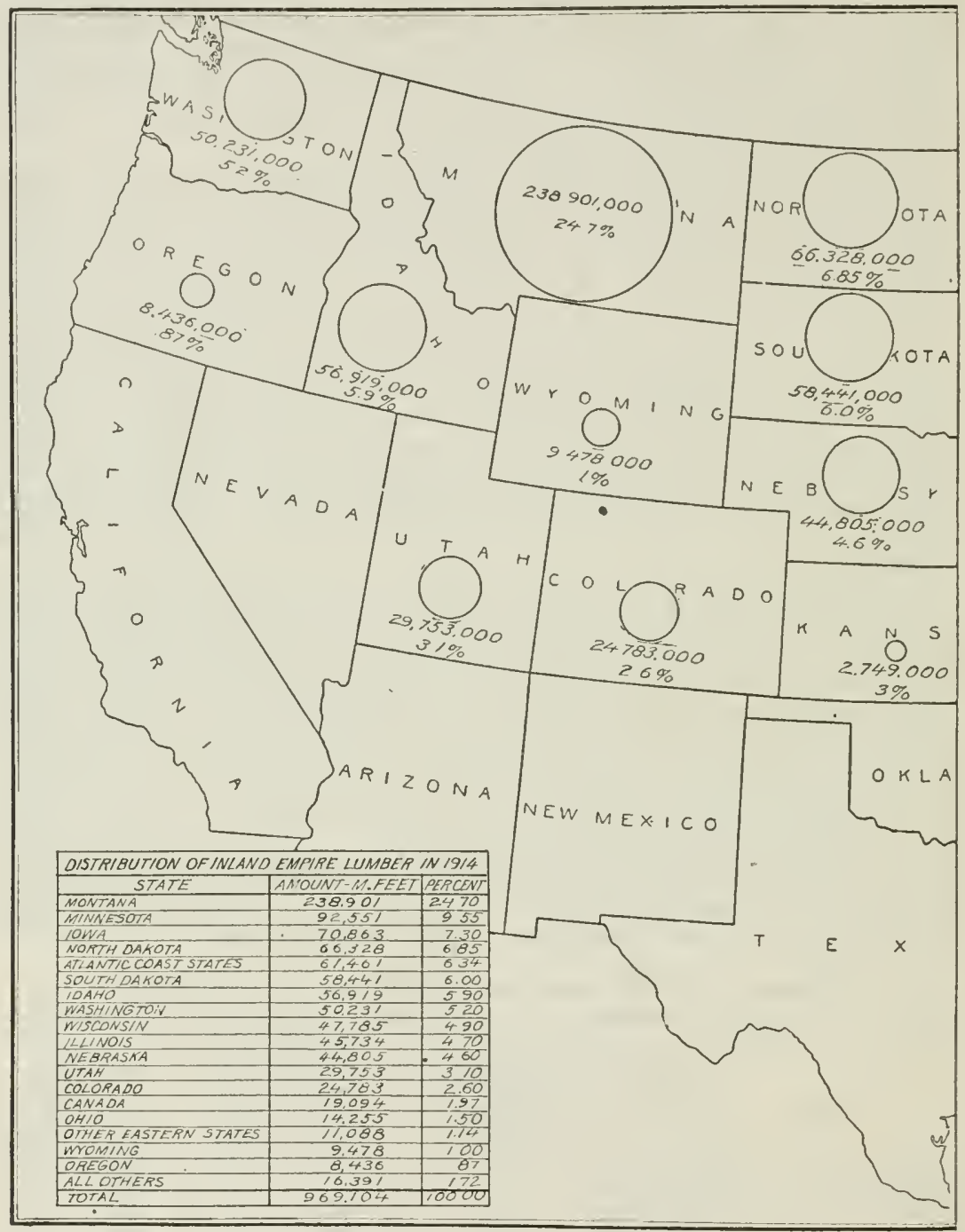

in eastern Montana and going on in the Dakotas, the spring of 1910 found conditions excellent in the lumber business. The 1910 drought made itself felt in lumber shipments when the crop failure beeame well assured, by midsummer. In the following spring business recovered somewhat, but a slump again took place, due to another erop failure in 1911, followed by a slight piek-up in the fall. In 1912, business conditions throughout the country were generally improving and lumber shipments rose rapidly until June. On a well assured, magnificent crop the fall business rose still higher. Business was not so good in 1913 as in 1912, although it started out vigorously 
at the beginning of the year. 1914 started out about as well as 1913, but the effect of the war was plainly evident in the latter part of the year. A good 1914 crop with war prices, however, brought shipments back in the early part of 1915; the midsummer business of 1915 was nearly as good as that of 1912; and the shipments in the late fall and winter months were the best that the Inland Empire has ever experienced at that time of year, because of the general wave of prosperity beginning in the fall of 1915.

Other data from the two lumber manufacturers' associations shows even more strikingly the effect of crop years and other local conditions in specific States. The

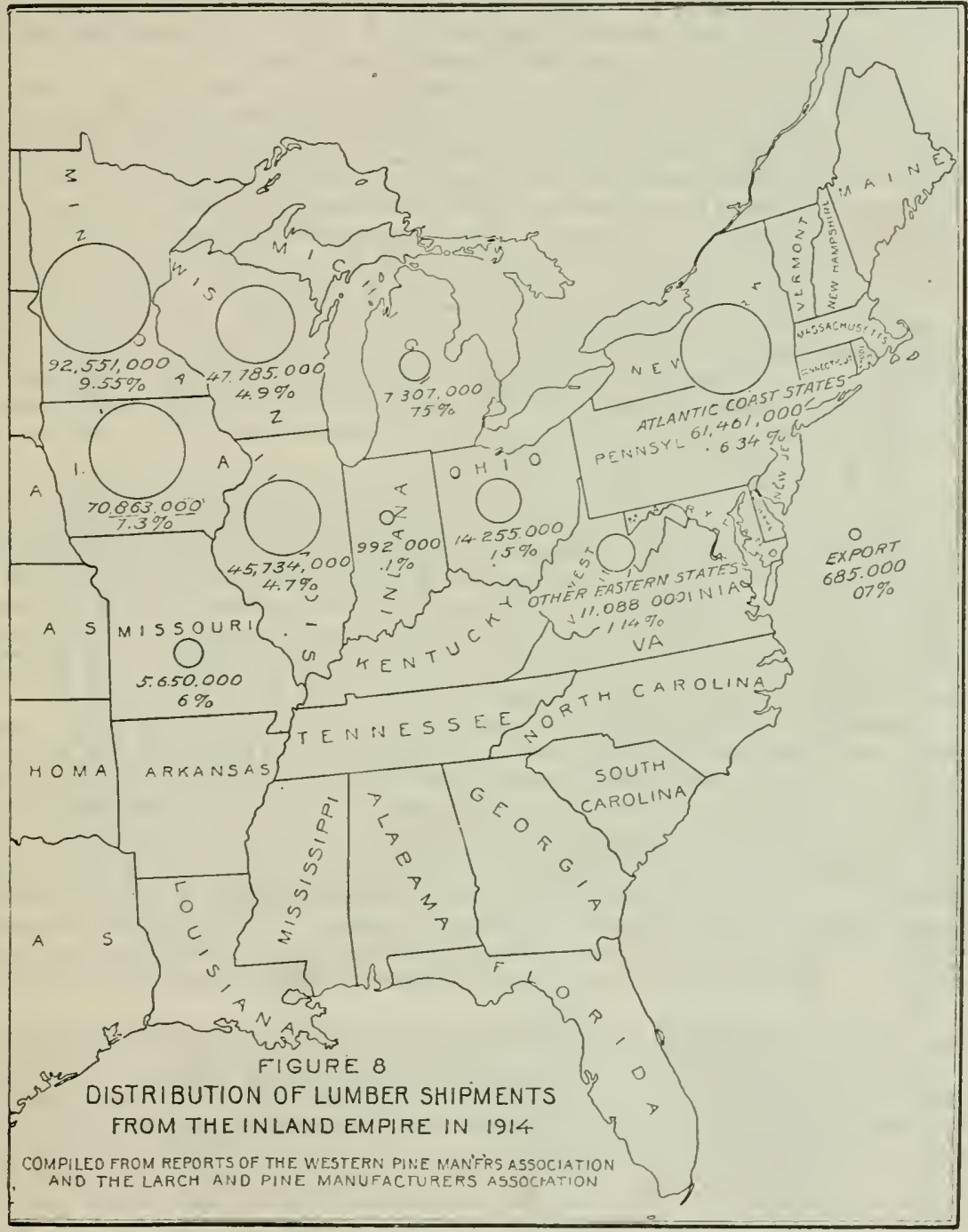

shipments to Canada show the very rapid progress of settlement in the prairie provinces taking place between 1909 and 1913, but reflect the business depression in that country during the next two years. The effect of the freight rate change, shutting the product of northwest Montana mills out of North Dakota, also stands out clearly.

FREIGHT RATES ON LUMBER.

In 1883, when the Northern Pacific Railway completed its line to the coast, it put into effect a rate of 50 cents per hundred pounds on lumber to its eastern ter- 
minals. The Great Northern, completed in 1893, immediately cut this rate to 40 cents, partly to get business from the North Pacific and partly to fill the empty cars moving east. The Northern Pacific met this rate. Up to about 1897, there was so little development of the lumber industry in the Inland Empire that there was no objection to the railroads keeping the coast rate and the Inland Empire rate to eastern points blanketed together at the same figure. About 1897 the Kalispell region in northwestern Montana began to develop, and secured favorable rates from the Great Northern to Montana and Dakota points. About the same time the early mills in the Missoula region obtained similarly favorable rates from the Northern Pacific. A little later, in 1900 to 1902, as mills were established near Spokane they also received rates lower than those from the Coast. At about the same time the eastern Oregon mills secured from the O.-W. R. \& N. Co. differentials under the Coast rates to Rocky Mountain and Missouri River points.

In 1907 this railway rate structure, gradually evolved in response to the developing lumber industry, was upset by united action on the part of the railways, which increased all eastbound lumber rates from 10 to 25 per cent. The western lumbermen objected to any general inerease owing to its effect upon their competition in Mississippi Valley markets with the Southern and Lake States product. The West Coast lumbermen objected to the new rates, since the differentials in favor of various parts of the Inland Empire were increased. The Coast appealed the case to the Interstate Commerce Commission, which restored the old 40 cent rate for the Dakotas but allowed an increase to 45 cents to the Minnesota Transfer (St. Paul-Minneapolis).

The Spokane group of mills then appealed to the Interstate Commerce Commission for a larger differential than the 5 cents per hundred pounds granted in the Coast case, and also for blanket rates to the Mississippi Valley covering all the lumber producing territory from Spokane to the Continental Divide. The decision, instead of increasing, reduced the differential from 5 to 3 cents to the Minnesota Transfer, gave a small differential to mills on the east slope of the Caseades, and established the blanket rates mentioned above.

The Kalispell mills could not stand this situation, for, owing to their heavier timber, the blanket rate in effect took away the most important part of their market. So Kalispell next appealed to the Commission, and succeeded in getting back part of the differential lost. As a consequence, shipments from the Kalispell Region into North Dakota fell off from approximately 50 million feet per year before 1907 to about 10 million after that year. Fortunately for this producing region, the rapid settlement of eastern Montana beginning at this time furnished new demands more than sufficient to make up for the loss of the North Dakota market. The Missoula region appealed to the Commission at the same time for similar relief from the blanket rates, and secured differentials similar to those granted Kalispell.

These four cases established the present rate structure, although several minor and more or less local changes have since taken place. The freight rate situation as it is now exists in the Inland Empire is illustrated by Figure 9. Butte can obtain lumber from Seattle, a distance of about $7 \$ 0$ miles, on a rate of 35 cents per hundred pounds; or can bring its lumber 380 miles from Spokane for 20 cents, 310 miles from Saudpoint for 16 cents, or 120 miles from Missoula for 10 cents. This gives Missoula a 6 cent differential under Sandpoint, 10 cents under Spokane, and 25 cents under Seattle. To Livingston, Montana, the Missoula differential is $\mathrm{S}, 10$, and 15 cents, respectively, under the other three producing points. At the Minnesota Transfer, Missoula is blanketed with Sandpoint and Spokane with a 3 cent differential under Seattle. This same blanket and 3 cent differential then holds all the way to New York.

Table 30 (Appendix) gives additional data with regard to freight costs on about 25 per cent of the 1913 shipments. These particular shipments include the more valuable products, shipped on somewhat higher rates than the average. The average mill value of the lumber included was $\$ 16.25$ per thousand feet, or $\$ 1$.1S more than the average value of all of the lumber sold in 1913. The average carload of this lumber had a mill value of $\$ 406$; the freight charge to destination was $\$ 206$, or slightly over 50 per cent of the mill value of the lumber. The average freight rate on all Inland Empire lumber is about $\$ 7.50$ per thousand feet, or about 50 per cent of the mill price.

The transportation companies of the country receive, it is estimated, approximately 12 million dollars annually on shipments of Inland Empire lumber, these shipments amount yearly to about $1,680,000$ tons of freight. In addition to hauling lumber, the railways of the Inland Empire secure considerable revenue from hauling saw logs and other forest products. It has been stated that over 50 per cent of the traffic of some of the principal carriers of the Inland Empire consists of forest products. That the stability of the lumber industry of thejnland Empire has an important relation to the prosperity of its railways, no one can doubt. 
Freight Rates in Cents Per 100 Pounds

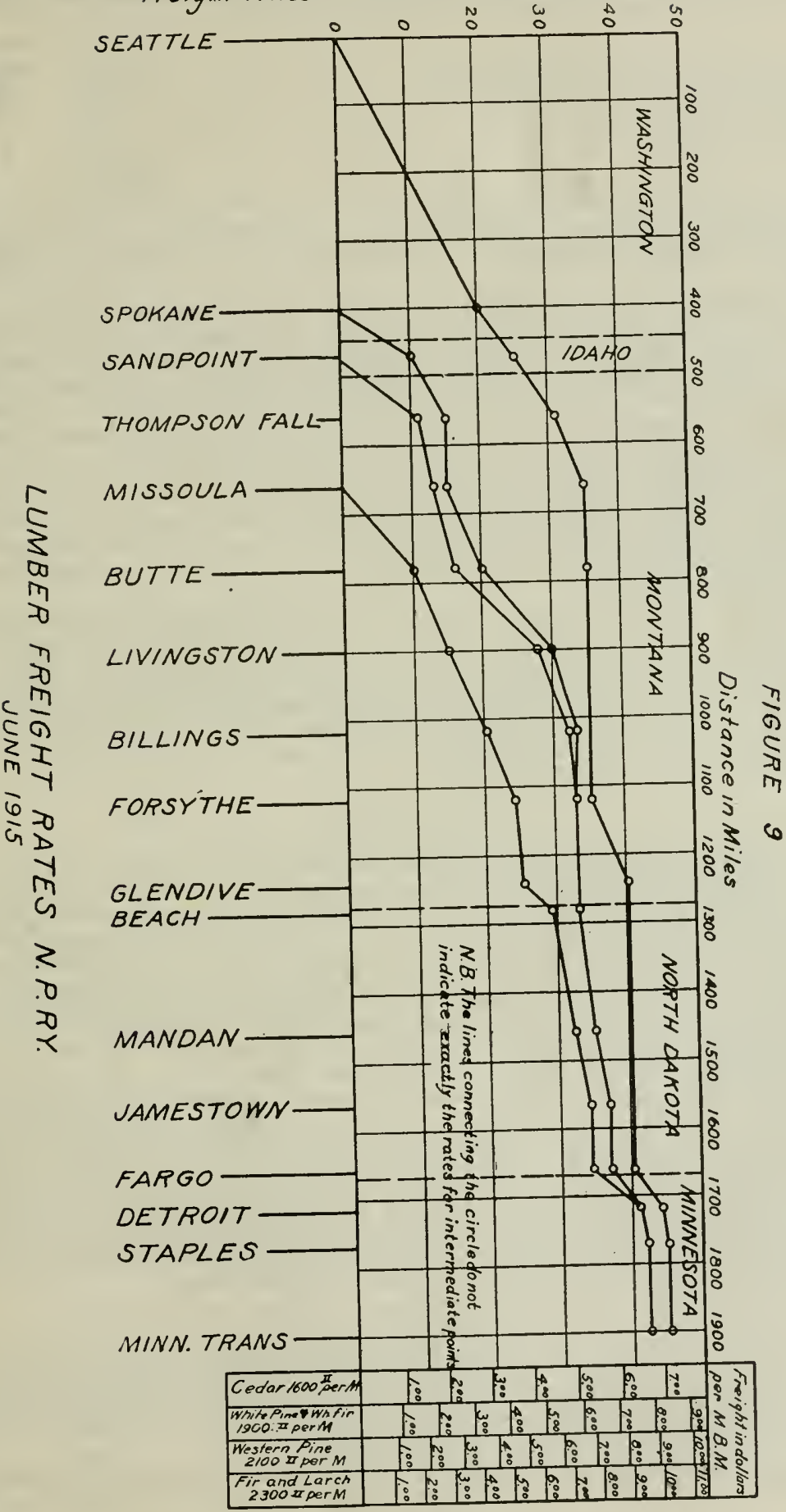


The investigation of the distribution of lumber in the Mississippi Valley has secured data which are of interest at this point. Lumber purchased and resold by city yards and by country yards is considered separately. Manufacturer's price on car at the mill ............. $\$ 13.95$

Added to the price by the wholesaler $\ldots \ldots \ldots \ldots \ldots \ldots \ldots \ldots \ldots \ldots \ldots$
Added by railroad freight $\ldots \ldots \ldots \ldots \ldots \ldots \ldots \ldots$

To city

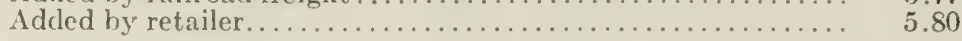

Tocountry yards.

$\$ 15.94$

Total paid by consumer.................. $\overline{\$ 26.44}$

In the city retailer's price there is included a profit of about 6 per eent on his investment; the country retailer's price gives him about 10 per cent net on his investment.

It is rather commonly believed by lumbermen that lumber takes an unduly high freight rate as compared with other commodities. The arguments in favor of a low rate on lumber are that it is a low grade freight, that it loads heavily, needs no special cquipment or speed in transit, is not unduly seasonal in move ment, moves in large volume, and that it is but very slightly susceptible to damage and claims.

Table 31 (Appendix) shows that the Inland Empire lumber shipped to the Atlantic seaboard consists principally of white pine, with some western pine. Proceeding west, the proportion of white pine decreases, that of western pine increases, and Douglas fir, larch, spruce, and white fir make up a much larger share of the whole. The more valuable species and the higher grades will stand the expense of the longest shipments. Lumber is generally well seasoned and planed before it is shipped, to reduce the shipping weight as much as possible preparatory to the long hauls common from the Inland Empire.

In accordance with the general practice in handling lumber, the lumberman selling the product quotes a certain price per thousand feet delivered to the retailer or other purchaser at some market point. This price is based upon the "listed" or average shipping weight of the species and grade. The lumberman pays the freight and gets the advantage of whatever underweight there may be through very careful seasoning, and loses whenever the lumber is shipped with too much moisture in it. Thus he is the one to deal directly with the railroads in regard to promptness of shipments, claims, and other traffic matters.

\section{SELLING METHODS.}

The ordinary selling organization of the Inland Empire manufacturer is a sales manager, responsible directly to the general manager of the plant, and one or more salesmen under his direction on the road. In a group of 17 companies selling about 550 million feet annually direct to retailers, there were 12 sales managers and 51 salesmen. These men cost the companies an average of approximately $\$ 1,000$ each, including traveling expenses but exclurling office expenses for stenographic help, stationery, etc. This results in a cost of approximately $\$ 200,000$ for the lumber so disposed of, or about 36 cents per thousand feet. These men, including the sales managers, sold approximately 8.7 million feet per man annually. The salesman on the road averaged about 11 million feet of sales per year.

Table 6 shows that the average cost of selling over three and one-half billion feet of lumber in the six years, 1909-1914, inclusive, was 43 cents per thousand feet. This covers all the lumber sold and all methods of selling by the mills included. Under the present competitive condition in the industry there is duplication in selling costs, for very frequently the salesmen of different manufacturers call on the same customer one after another. One man could readily handle the business of several companies, a plan which would tend to make the market more stable. The competition of the present salesmen is principally through price cutting rather than constructive salesmanship based on the quality of the product.

Another arrangement for selling on the part of Inland Empire manufacturers is through wholesalers, who are ordinarily granted a reduction of one dollar per thousand feet from the price at which lumber is sold through the company's own salesmen to the retail trade. The service rendered by the wholesaler consists in finding business for the manufacturer which the latter otherwise would have to find for himself at his own expense, in carrying the account, and also in taking the risks inherent in passing the product along to the retailer.

Another method of selling is through commission men, who merely secure orders for lumber and turn them over to the manufacturer. For this service they receive a 
commission usually of 50 cents per thousand feet, or about what it costs the company to secure its own business.

Some companies market a considerable part of their product through lines of retail yards which they control or which are owned by the same stockholders. The dealings of a particular manufacturer with its related retail yards, however, are not as close as one might imagine; for generally the retail line yards buy wherever they can buy most cheaply, whether of the parent company or not; and the parent company sells wherever it can get the best price. But the two branches of the business operated jointly are usually a source of mutual help.

In a few cases companies make contracts with wholesalers under which the wholesaler advances funds to the manufacturer, to be returned later in the form of lumber. The wholesaler in this case ordinarily gets his lumber at a better figure and receives interest on the money which he has loaned. The manufacturer selects this method of selling as a means of financing his operation. This arrangement is ordinarily used only when the financing of the company is difficult, for it is generally to the disadvantage of the manufacturer.

In some cases sales are made through wholesalers who are in control of or deeply interested in the manufacturing company. In these instances the wholesalers obtain the lumber at a price insuring an adequate return on their risks in taking over the disposal of the mill product.

A number of the mills cutting white pine have taken advantage of the larger unit principle and organized a selling agency, with the object of securing, in a limited portion of the market and for white pine only, the advantages of larger stocks than any one company possesses. This agency has not been in operation long enough to demonstrate fully its possibilities. Successful operation requires that the head of the agency be a competent sales manager, that he understand thoroughly the stocks available at the different member mills, and that he hold the full confidence of the manufacturing companies. On the other hand, it is essential that the mills adapt their product and manufacturing practice as far as may be necessary to the business developed by the agency.

It is the practice of the manufacturer to grant a trade discount of 2 per cent for cash within 15 days and 1 per cent within 30 days; and to charge interest for periods exceeding 60 days. This custom is sometimes abused, especially in the case of weak companies; the purchaser does not pay cash within 60 days but does secure the 2 per cent deduction.

As in the case of any commodity, complaints occasionally develop owing to the condition of lumber when received. The manufacturers of the Inland Empire handle such cases usually through the inspection force of the Western Pine Manufacturers' Association. This Association maintains one or two inspectors east of the Rocky Mountains, mainly for reinspection work in connection with complaints. The method pursued is to re-grade the lumber to determine its condition upon arrival in the hands of the purchaser and see whether it is as specified in the original invoice. The reinspection sometimes shows that the lumber was up to grade when shipped but deteriorated in transit from improper seasoning and consequent staining in the car; or it may show that damage occurred in transit caused by dirty cars. More rarely it is found that the grade has been "sweetened" by adding some lumber of the next higher grade in order to secure further orders from the same purchaser in times when it is difficult to sell. In a similar way when the manufacturer holds the upper hand the grades may be "robbed" of the boards of better quality near the upper limit of the grade, or a percentage of distinctly lower grade lumber included in the shipment.

In a few cases it has been shown that a wholesaler has purchased lumber on one invoice from the manufacturer and substituted a new invoice in which grades are arbitrarily raised to the subsequent purchaser. In general the party at fault, purchaser or shipper, stands the cost of the reinspection; and if a claim on the part of the purchaser is found valid it is up to the millman to make good. The cost of settling complaints, aside from adjusting the claim itself, is approximately one-half cent per thousand feet on shipments subject to this method of settlement.

\section{LUMBER PRODUCTION COSTS}

The cost of producing lumber from 1909 to 1914, exclusive of stunpage and interest charges, averaged $\$ 12.23$ per thousand Joard feet mill tally, leaving a margin of $\$ 2.62$ between this cost and the returns on the product. Interest on borrowed capital used up, on the average, $\$ 0.55$ of the margin, and stumpage was charged on the books at $\$ 2.67$, thus leaving a paper deficit of $\$ 0.60$ per thousand feet. The cost of logging increased about $\$ 1$ per thousand during the period. Labor varied decidedly in efficiency, especially in the woods; and wages were rising on the whole. Labor 

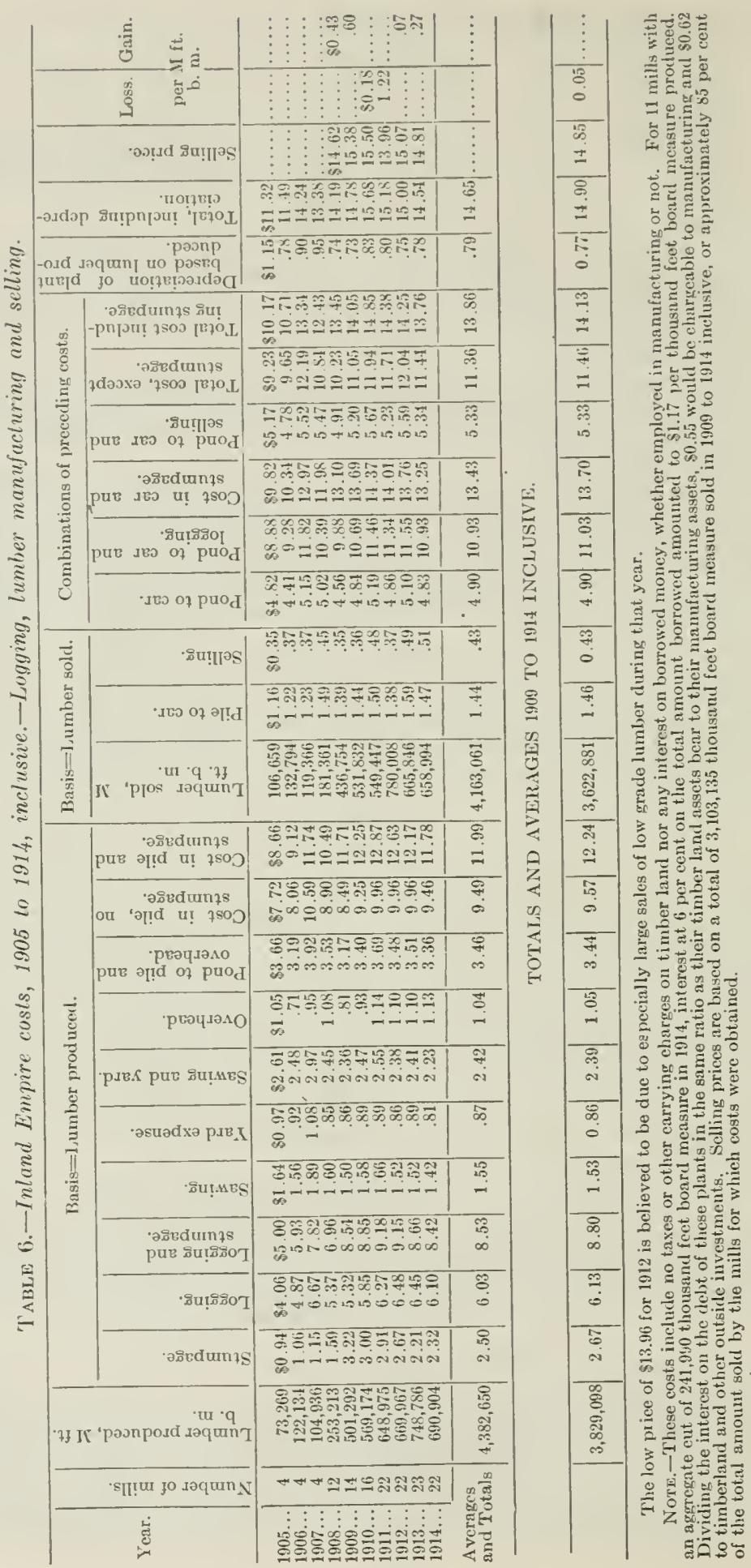
conditions require careful study and can be considerably improved. The industry paid about $\$ 13,500,000$ annually to the men employed.

Table 6 indicates in some detail for the period 1905 to 1914, inclusive, the cost of producing lumber, together with the price realized from its sale and the net profit or loss. At the beginning of this ten-year period only 4 mills are represented, while for the last four years it was possible to secure usable data from 22 or 23 mills. The table includes data on lumber produced to the extent of about 4,380 million feet or approximately 30 per cent of the 14.5 billion feet of lumber manufactured in the Inland Empire during this period. Stumpage is introduced as a cost in Table 6 at the rate at which it is charged on the books of the manufacturing companies, whether actually purchased from some other owner for immediate cutting or taken from their own stumpage holdings. As previously indicated, the rates charged on the books of the companies include, on the average, a material profit on the investment in timberland.

This table shows that the average cost of logging from 1909 to 1914 inclusive was $\$ 6.13$ per thousand feet, on a lumber basis (equivalent to $\$ 7.35$ on a log basis). If the book charge for stumpage is added, the average cost of logs delivered in the log pond was $\$ S . S 0$ lumber basis (equivalent to $\$ 10.55 \mathrm{log}$ basis). (The figures used in the text of this report from this point are on a lumber tally basis unless otherwise stated.)

The cost of sawing the logs into lumber and piling the lumber in the mill yard averaged $\$ 2.39$ per thousand feet. The cost of handling lumber from the pile through the planing mill and into the car ready for shipment averaged \$1.46. Selling expense averaged $\$ 0.43$ and overhead expenses $\$ 1.05$ per thousand feet. The operating costs at the mill, from log pond to car, total $\$ 5.33$. To this amount, however, should be added $\$ 0.79$ for.plant depreciation, bringing the mill total to $\$ 6.12$.

The total cost of production, exclusive of stumpage, is $\$ 12.23$, or $\$ 14.90$ including stumpage as entered on the books. So far no allowance has been made for interest on indebtedness: if this is included, it adds $\$ 0.55$, and brings the total stumpage, logging, and milling cost to $\$ 15.45$. All of there figures were taken directly from company books, excepting depreciation, which, for certain reasons discussed later, had to be estimated, and excepting interest, which had to be apportioned as indicated at the foot of the table.

The figures prior to 1908 are not so satisfactory as the later ones, owing to the smaller number of mills included. The average book charge for stumpage rose from $\$ 0.94$ in 1905 to $\$ 3.22$ in 1909 , and dropped to $\$ 2.32$ in 1914 ; the reasons for this are discussed in connection with stumpage values. The average cost of logging advanced in a somewhat erratic way from $\$ 4.06$ in 1905 to $\$ 6.45$ in 1913 ; in 1914 it declined $\$ 0.35$. The general reason for this increase has been the decreasing accessibility of the timber. In each of the other classifications the average cost has not fluctuated widely since 1908 and shows no very definite trend, excepting that overhead and selling expense increased somewhat.

Table 7 gives the average, maximum, and minimum figures for each item of cost set forth in Table 6 . One would expect wide spreads between the maxima and minima for stumpage, logging, and selling expenses, for reasons pointed out in this report. For sawing, yard expense, overhead, and handling from pile to car such wide spreads would not be expected. For instance, take the item of sawing in 1914 the highest sawing cost was $\$ 2 . \$ S$, the lowest $\$ 0.96$, and the average $\$ 1.42$. Sawing is a fairly well standardized process. The high mill may have some entirely unusual expenses; perhaps the low mill sacrificed quality of work to speed; but even then the average is entirely too high above the minimum, and it looks as though there were opportunity for most of the mills to reduce their sawing costs. Similarly the large differences between maximum, minimum, and average costs for yard expense, overhead, and "pile to car" incline one to believe that the average mill lags considerably behind the best in efficiency. 
TABLE 7.-Maximum, minimum, and average costs of various divisions of lumber production al Inland Empire mills, 1905 to 1914, inclusive.

\begin{tabular}{|c|c|c|c|c|c|c|c|}
\hline \multirow[b]{2}{*}{ Year } & \multicolumn{5}{|c|}{ Based on lumber produced } & \multicolumn{2}{|c|}{ Based on lumber sold } \\
\hline & Stumpage & $\left|\begin{array}{c}\text { Logging } \\
\text { and } \\
\text { transport }\end{array}\right|$ & Sawing & $\begin{array}{c}\text { Yard } \\
\text { expense }\end{array}$ & Overhead & Pile to car & $\begin{array}{l}\text { Selling } \\
\text { expense }\end{array}$ \\
\hline 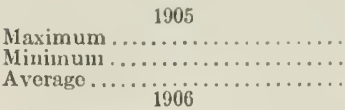 & $\begin{array}{r}\$ 1.74 \\
.81 \\
.94\end{array}$ & $\begin{array}{r}\$ 4.49 \\
3.98 \\
4.06\end{array}$ & $\begin{array}{r}\$ 1.69 \\
1.59 \\
1.64\end{array}$ & $\begin{array}{r}81.07 \\
.68 \\
.97\end{array}$ & $\begin{array}{r}\$ 1.37 \\
.70 \\
1.05\end{array}$ & $\begin{array}{r}\$ 1.79 \\
1.04 \\
1.16\end{array}$ & $\begin{array}{r}80.42 \\
.31 \\
.35\end{array}$ \\
\hline 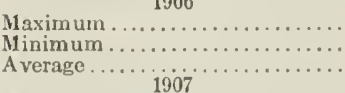 & $\begin{array}{r}1.84 \\
.68 \\
1.06\end{array}$ & $\begin{array}{l}5.41 \\
4.07 \\
4.87\end{array}$ & $\begin{array}{l}1.67 \\
1.34 \\
1.56\end{array}$ & $\begin{array}{r}1.07 \\
.79 \\
.92\end{array}$ & $\begin{array}{r}1.00 \\
.43 \\
.71\end{array}$ & $\begin{array}{l}1.94 \\
1.01 \\
1.22\end{array}$ & $\begin{array}{l}.47 \\
.32 \\
.37\end{array}$ \\
\hline $\begin{array}{l}\text { Maximum } \ldots \ldots \ldots \ldots \ldots \ldots \ldots \ldots \ldots \ldots \\
\text { Minimum } \ldots \ldots \ldots \ldots \ldots \ldots \ldots \ldots \ldots \\
\text { Average } \ldots \ldots \ldots \ldots \ldots \ldots \ldots\end{array}$ & $\begin{array}{r}1.71 \\
.89 \\
1.15\end{array}$ & $\begin{array}{l}8.20 \\
5.21 \\
6.67\end{array}$ & $\begin{array}{l}2.39 \\
1.54 \\
1.89\end{array}$ & $\begin{array}{r}1.22 \\
.84 \\
1.08\end{array}$ & $\begin{array}{r}1.17 \\
.71 \\
.95\end{array}$ & $\begin{array}{r}1.35 \\
.43 \\
1.23\end{array}$ & $\begin{array}{l}.68 \\
.30 \\
.37\end{array}$ \\
\hline 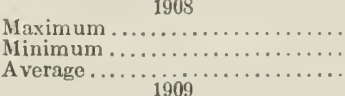 & $\begin{array}{r}3.23 \\
.66 \\
1.59\end{array}$ & $\begin{array}{l}7.52 \\
3.96 \\
5.37\end{array}$ & $\begin{array}{r}2.69 \\
.89 \\
1.60\end{array}$ & $\begin{array}{r}1.20 \\
.56 \\
.85\end{array}$ & $\begin{array}{r}2.75 \\
.57 \\
1.08\end{array}$ & $\begin{array}{r}2.44 \\
.95 \\
1.49\end{array}$ & $\begin{array}{l}.92 \\
.32 \\
.45\end{array}$ \\
\hline 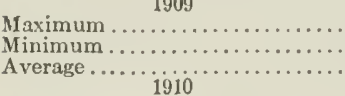 & $\begin{array}{r}6.12 \\
.78 \\
3.22\end{array}$ & $\begin{array}{l}8.44 \\
3.82 \\
5.32\end{array}$ & $\begin{array}{r}2.44 \\
.90 \\
1.50\end{array}$ & $\begin{array}{r}1.17 \\
.57 \\
.86\end{array}$ & $\begin{array}{r}1.43 \\
.53 \\
.81\end{array}$ & $\begin{array}{r}2.63 \\
.89 \\
1.39\end{array}$ & $\begin{array}{l}.73 \\
.00 \\
.35\end{array}$ \\
\hline 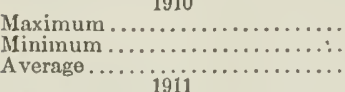 & $\begin{array}{r}6.21 \\
.93 \\
3.00\end{array}$ & $\begin{array}{l}8.42 \\
4.57 \\
5.85\end{array}$ & $\begin{array}{l}2.28 \\
1.00 \\
1.58\end{array}$ & $\begin{array}{r}1.21 \\
.62 \\
.89\end{array}$ & $\begin{array}{r}2.16 \\
.51 \\
.93\end{array}$ & $\begin{array}{r}2.23 \\
.80 \\
1.44\end{array}$ & $\begin{array}{l}.73 \\
.06 \\
.36\end{array}$ \\
\hline $\begin{array}{l}\text { Maximum } \ldots \ldots \ldots \ldots \ldots \ldots \ldots \ldots \ldots \ldots \\
\text { Minimum } \ldots \ldots \ldots \ldots \ldots \ldots \ldots \ldots \ldots \ldots \\
\text { Average } \ldots \ldots \ldots \ldots \ldots \ldots \ldots\end{array}$ & $\begin{array}{r}5.54 \\
.74 \\
2.91\end{array}$ & $\begin{array}{r}12.16 \\
4.38 \\
6.27\end{array}$ & $\begin{array}{r}4.37 \\
.89 \\
1.66\end{array}$ & $\begin{array}{r}1.21 \\
.58 \\
.89\end{array}$ & $\begin{array}{l}3.00 \\
.74 \\
1.14\end{array}$ & $\begin{array}{r}2.63 \\
.87 \\
1.50\end{array}$ & $\begin{array}{r}1.08 \\
.16 \\
.48\end{array}$ \\
\hline $\begin{array}{l}\text { Maximum } \ldots \ldots \ldots \ldots \ldots \ldots \\
\text { Minimum } \ldots \ldots \ldots \ldots \ldots \ldots \\
\text { Average } \ldots \ldots \ldots \ldots \ldots\end{array}$ & $\begin{array}{r}4.65 \\
.88 \\
2.67\end{array}$ & $\begin{array}{l}9.95 \\
4.34 \\
6.48\end{array}$ & $\begin{array}{r}2.33 \\
.87 \\
1.52\end{array}$ & $\begin{array}{r}1.30 \\
.61 \\
.86\end{array}$ & $\begin{array}{r}1.73 \\
.70 \\
1.10\end{array}$ & $\begin{array}{r}2.25 \\
.88 \\
1.38\end{array}$ & $\begin{array}{r}1.00 \\
.05 \\
.37\end{array}$ \\
\hline $\begin{array}{l}\text { Maximum } \ldots \ldots \ldots \\
\text { Minimum .......... } \\
\text { A verage...... }\end{array}$ & $\begin{array}{r}3.69 \\
.84 \\
2.21\end{array}$ & $\begin{array}{l}8.51 \\
3.42 \\
6.45\end{array}$ & $\begin{array}{r}2.33 \\
.94 \\
1.52\end{array}$ & $\begin{array}{r}1.27 \\
.65 \\
.89\end{array}$ & $\begin{array}{r}3.86 \\
.73 \\
1.10\end{array}$ & $\begin{array}{r}2.08 \\
.90 \\
1.59\end{array}$ & $\begin{array}{r}1.48 \\
.03 \\
.49\end{array}$ \\
\hline $\begin{array}{l}\text { Maximum } \ldots \ldots \ldots \\
\text { Minimum ........ } \\
\text { Average........ }\end{array}$ & $\begin{array}{r}3.76 \\
.75 \\
2.32\end{array}$ & $\begin{array}{l}7.92 \\
3.64 \\
6.10\end{array}$ & $\begin{array}{r}2.88 \\
.96 \\
1.42\end{array}$ & $\begin{array}{r}1.45 \\
.58 \\
.81\end{array}$ & $\begin{array}{r}3.29 \\
.62 \\
1.13\end{array}$ & $\begin{array}{r}2.07 \\
.77 \\
1.47\end{array}$ & $\begin{array}{r}1.44 \\
.02 \\
.51\end{array}$ \\
\hline
\end{tabular}

Nоте.-The maximum and minimum cost items shown above are the highest and lowest, respectively, at all the mills included in Table 6. The mill showing the maximum sawing cost may in the same year show the minimum cost "pile to car."

Different lumbermen group costs differently, and so misunderstand one another more or less when discussing costs. In Tables 6, 7, and 8, however, great care was taken to classify the different items of cost uniformly. This made it necessary to discard the records of a number of mills where costs had not been kept in sufficient detail to permit such a classification. Lack of a uniform cost accounting system is a weakness in the industry.

In Table 8 the principal divisions of cost have been itemized still further for a considerable number of representative companies having data in sufficient detail. The cost of "logging in place" (getting the log from the standing tree to the principal method of transportation, such as drivable stream or railway) tended to increase materially in the ten years, as also the cost of transportation. In a few cases, it is believed that the railroad company is securing more freight than the service is really worth. These are generally cases where the lumber company (or its owners) is more or less directly interested in the railway and for one reason or another wishes to help out the railway enterprise at the expense of the lumber operation. What fair costs under such circumstances would be it is impossible to say, and at most the effect on the average figures is not material. 
TABLE 8.-Production cost analysis, Inland Empire averages, 1905 to 1914.

Log cost:

Stumpage

Logging-

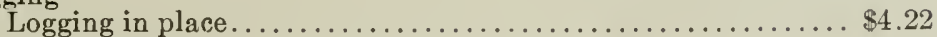

Transportation ..................................... 1.81

Mill cost:

Sawing-

Rooms and pond labor and expense................. .

Sawmill. labor...................................... 1.19

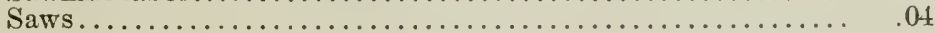

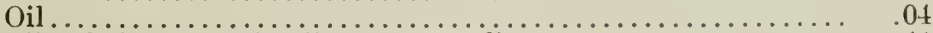

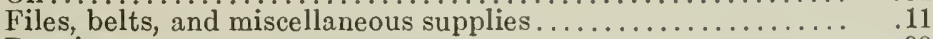

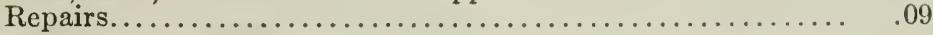

Yard expense:

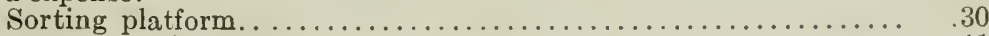

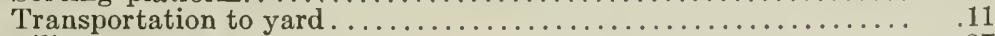

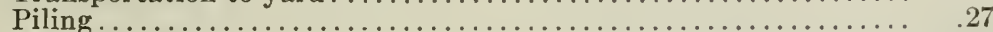

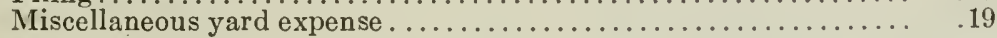

Overhead:

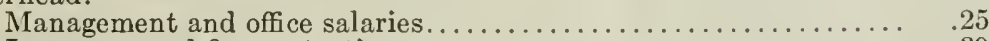

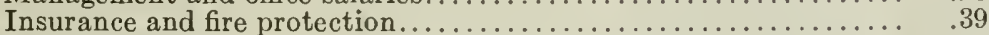

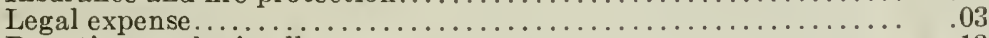

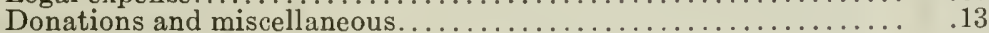

Taxes on plant and personal property .................... 24

Pile to car:

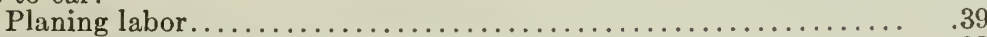

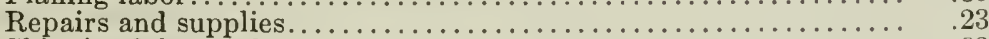

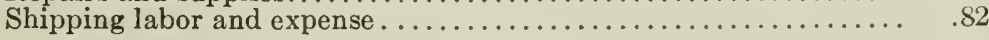

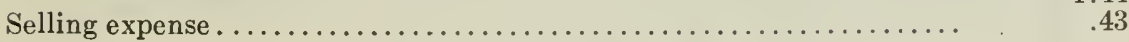

Depreciation of plant............................. $\quad .79$

Nоте.-This analysis of the average costs shown in Table 6 was made by prorating the costs obtainable from mills in the detail shown here against those averages on a percentage basis.

Of the $\$ 6.12$ cost of milling, including depreciation, indicated in Table 8 , about 54 per cent goes directly to labor and about 10 per cent to salaries. Part of the other third of the total goes indirectly for labor employed in producing hay, saws, belts, etc. It is estimated that about 85 per cent of the $\$ 6.03$ logging cost also goes to labor and salaries. A portion of the remainder is expended indirectly for labor employed in producing supplies used in logging. On this basis, the industry pays its employees over $\$ 13,500,000$ annually, in addition to large sums for supplies of all kinds and for railway freights.

Table 6 shows the general condition of the best and most successful lumber companies in the Inland Empire during the period under consideration. From 1909 to 1914 inclusive there was an average loss of 5 cents per thousand feet after allowing a reasonable amount for the depreciation of the plant, but making no allowance for interest on borrowed money. This of course leaves out of account the profit on investments in timberland, since stumpage is taken at its book value.

Between 1913 and 1914 the cost of logging was reduced 35 cents per thousand, or 5.4 per cent. This was due principally to reduced wages and the increased efficiency of labor. The changing accessibility of the timber has doubtless had some influence, but probably in the opposite direction. Reductions in cost were also made by other branches of the operation in which labor is the principal item; sawing was reduced 6.6 per cent; yard expense 11.1 per cent; and the cost of handling from 
pile to car 7.5 per cent. Figure 10, showing the cost of lumber production, presents graphically this tendency toward a lowering of costs from 1913 to 1914.

LABOR COST.

It is believed that the lower cost of labor per unit of output in 1914 is the most important factor in the reduction of operating expenses. Figure If (Appendix) shows the movement of wages of different elisses of labor employed in logging and milling. The showing on the whole is that wages rose just before 1907 , fell off somewhat after the panic of 1907 , rose from 1910 to 1912 , and decreased in 1914 and

\section{FIGURE 10}

COST OF PRODUCING LUMBER IN THE INLAND EMPIRE

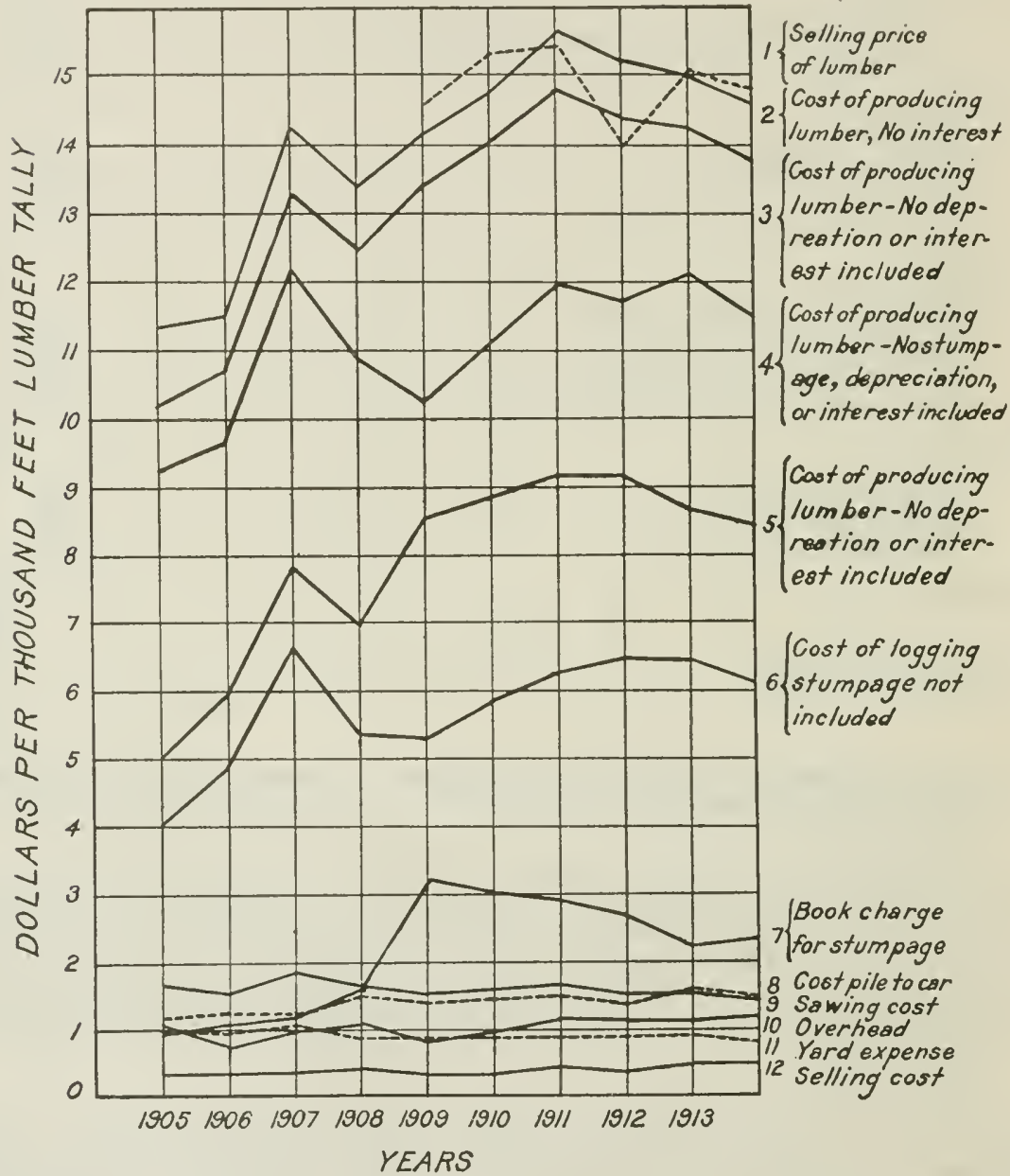

1915. The drop is shown most definitely at the beginning of 1915 . Wages rose again in 1916, but data were not available for the graph.

The effect of this wage movement is reflected most clearly in curve 6 of figure 10 , which shows the cost of logging. When work becomes plentiful and labor is in demand, wages are increased and board often decreased in price and improved in quality, in order to secure and hold men. The men, with an assurance of jobs easily obtained, work for shorter average periods and fall off in efficiency. On the other hand, when the demand for and price of lumber fall off, which usually occurs simul- 
taneously with slack periods in other industries, the cut is curtailed and men are thrown out of employment. It becomes so easy to obtain men that wages are lowered, men work harder and more effectively to hold the jobs they get, the least effective men are eliminated from crews, and the price of board may be raised or the quality of food lowered. Thus a combination of forces is at work to reduce labor costs in hard times and increase costs in good times. Figure 16 (Appendix) shows that the charge for board was lower in 1912 than in 1914.

There is a great difference in the lumber industry between the labor employed at the mills and that employed in the woods. In the mill towns housing conditions and opportunities for recreation are generally fair. Steady men with families are available for work, and they stick to their jobs fairly well. In the woods, however, living conditions are generally unsatisfactory; too little attention is paid to the physical, mental, and moral welfare of the men. Many attribute this to the general belief or experience of operators that the lumberjack does not appreciate or respond to better surroundings. At any rate, the labor in the woods is usually of a poor quality and shifts rapidly; and its efficiency is low in consequence. The payroll of one company in 1914 showed on the average for each month 154 men in the woods for every 100 jobs. This meant on the average a new crew about every two months, or a complete turn over six times a year. The situation was considered unusually good, however, since in other years when labor was more in demand and consequently more independent, the turn over had been far more rapid, men in some cases averaging only about ten days on the job.

The 1910 census shows that the average number of men employed in woods and saw mills in California was about 23,000 , in Oregon about 15,000 , in Washington about 44,000 , in Idaho about 5,000, and in Montana about 3,000. About 14,000 of these men were employed in the Inland Empire, which is not far from the number now employed. When allowance is made for the men who have just been fired or have quit, for the men "blowing in their roll," and for the men hunting a new job, this number is increased by at least 25 per cent. These latter are to be reckoned with; for they form part of the whole number supported by the industry, and part of the force upon whom the industry must count to get its work done.

Unemployment in the lumber industry, as in others, represents a great economic loss to the laborer, to the industry, and to society. It is a problem which can be solved, at least in part, and is being partly solved by some lumbermen. ${ }^{1}$ Table 32 (Appendix) shows the seasonal character of work in the lumber industry. Employment is at the lowest ebb in the winter time. In Idaho less than 60 per cent as many hands are required in winter as in the summer and fall. In Montana the month of minimum employment still shows 70 per cent of the maximum.

\section{MANUFACTURERS' ASSOCIATIONS}

Trade association work in the Inland Empire is of great importance to the lumber industry. Its most important function is standardizing the grades of lumber and maintaining these standards both through inspection at the mills and through reinspection in connection with complaints made by purchasers. Price data from lumber sales are gathered, summarized, and redistributed. Railway traffic matters are handled; and many other less important things are done. The activities of trade associations should be extended materially, for there are many other important ways in which they can assist the manufacturer.

The Western Pine Manufacturers' Association, with headquarters at Portland, has in its membership about 45 of the principal companies in the Inland Empire, located in all parts of the region. The manufacturers of northwest Montana until very recently had an association of their own called the Montana Larch and Pine Manufacturers' Association; its members have now joined the Western Pine Association.

The principal function of the former Montana Association, which had about 12 members, representing a cut of approximately 125 million feet per year, was to grade lumber at the mill in order to standardize grades among the plants in its region. The Association also gathered statistics of various kinds, but no data on lumber prices. The secretary also conducted the fire protection work of the Northern Montana Forestry Association.

The work of the Western Pine Manufacturers' Association, representing an annual cut of approximately one billion feet, consists in standardizing grading by the members of the association by means of 3 or 4 inspectors constantly on their rounds among the mills and by reinspections in the markets east of the Rockies to determine the reasonableness of complaints made by customers. It also conducts an information bureau for about thirty of the mills, representing a cut of approxi-

1 See "The Labor Problem" in the final chapter of this report. 
mately 700 million feet. The members of the bureau furnish daily copies of all orders accepted, giving all the information on each order excepting the destination of the shipment. These orders are then reduced to a local mill price basis by proper deductions for freights; and a summary of the orders aecepted by each mill is distributed to all of the members of the bureau. This information has been found of material help in stabilizing the market.

The two men on the reinspection force in the East are also employed to gather data with regard to the kinds of lumber required for eastern use by various classes of users, and such other information as may appear to be of benefit to the manufacturers.

The association as such has also taken part in various forest products exhibits and is doing some co-operative advertising.

It conducts a traffic bureau which gathers all sorts of information on railroad tariffs, the service rendered by individual railroads, and similar matters. A traffic expert is employed to handle this work; one of his duties is to collect freight claims for members who care to turn this work over to the association. Members who turn over their bills of lading have them checked by the traffic bureau as to the correctness of the rates charged by the railroads, and if any overcharges are discovered claims are made. Nembers who turn all of their work over to the traffic department have it handled at a cost of 10 per cent of the overcharge collections. Other members prefer to handle all of the easy claims themselves, that is, claims for all amounts which they find readily upon inspection of their bills of lading, referring the resiclue to the association. The latter are naturally harder to discover and collect, and for services under this arrangement the traffic bureau charges 30 per cent of its collections.

The Association also gathers data of a more or less general nature and furnishes its members with bulletins from time to time giving information of interest. It recently arranged for a field agent of the American Red Cross Society to spend several months among the logging camps of the Inland Empire with the object of giving instruction in "first aid" work in all of the camps visited. This agent has also been giving attention to sanitation and to the improvement and standardization of camp conditions.

The Western Pine Association has been developed to a high state of usefulness; there are, however, a number of fields to which its activities could be extended with great benefit to its members. These possibilities are discussed further in the final chapter under the heading "Cooperation Through the Trade Association."

\section{THE RETURNS OF THE LUMBER INDUSTRY.}

\section{LUMBER PRICES}

The price received for lumber at the mill during the six-year period from 1909 to 1914 averaged $\$ 14.85$ per thousand feet for all species. Lumber prices have moved up and down in general reponse to the degree of prosperity in the country, but in their movement have lagged behind other commodities. The wide spread in prices on a given item of lumber on the same day indicates unhampered competition. The "price lists," which are prepared by the trade association and widely used, have the legitimate function of showing the relative values of different species, grades, widths, lengths, and patterns of lumber when delivered to the purchaser on different freight rates. Such lists would, of course, be useful in efforts to "fix" prices among the several mills; and for this reason have sometimes been looked upon askance from the standpoint of the public. In the Inland Empire lumber prices have been determined during the period under study, by the individual manufacturers; and the use of the list has been mainly to establish the relative value of different grades and items.

Since the summer of 1912 the Western Pine Manufacturers' Association, through its information bureau, has been collecting data which include the prices at which sales of lumber have been made by the members of the association subscribing to the bureau. Before that time no data are available to show the prices of lumber by species, grades, and dimensions, excepting the original invoices of shipments. To secure the same sort of data for 1908 to 1912 would involve going through many hundred thousand sale invoices. To show the general ups and downs of the market, however, it was undertaken to secure prices for certain items and grades of important species produced in the Inland Empire, direct from the original invoices of several representative companies. In doing this work about 60,000 invoices were examined. Western Pine Association data are used for the period following 1912.

To determine the general returns from sales of lumber prior to 1913 it was necessary to use the average mill price obtained by different plants in various years. These prices are, of course, variable from plant to plant because of the general price levels in the lumber markets, the proportion of species manufactured locally, the 


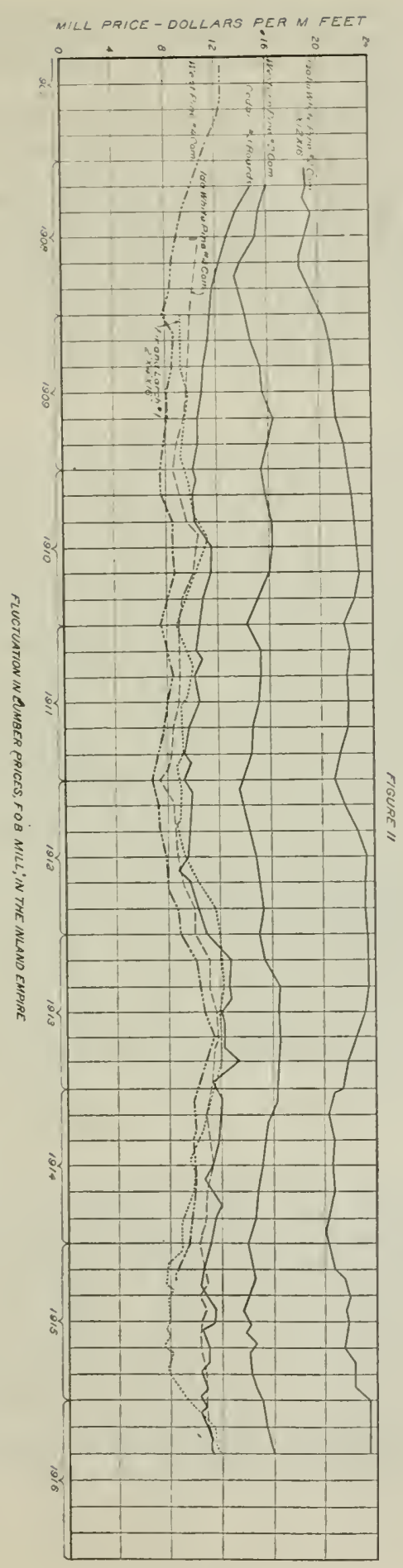


proportion of different grades secured, the cuality of the mill work or of the timber itself, whether or not the mill was sawing for the maximum volume or the best grades, ete. In spite of these differing conditions, the variation in average price is not so great as might be expected.

Table 9 summarizes the prices of various grades of white pine, western pine, and other Inland Empire species. The value of white pine did not fluctuate much before 1917 , for the species is well known and readily marketed at a fairly uniform price. Its average price held fairly elose to $\$ 18.75$ per thousand feet. Western pine dropped from about $\$ 17.50$ in 1913 to about $\$ 15.00$ in 1914 , and to about $\$ 13.50$ through most of 1915; in 1916 it rose to about \$16.50. Larch and Douglas fir dropped from about $\$ 12.75$ in 1913 to $\$ 10.50$ in 1914 , and $\$ \$ .75$ through most of 1915 . In 1916 they rose to about $\$ 12.50$. The other species have had price movements more or less similar to those of western pine, fir, and larch. These prices must still be adjusted for trade discounts, elaims, bad debts, "over weights" (lumber incompletely (Iried and entailing a freight charge above the estimated amount) and "under weights." The net result of this adjustment is to deduet from 20 to 35 cents per thousand feet from the selling price.

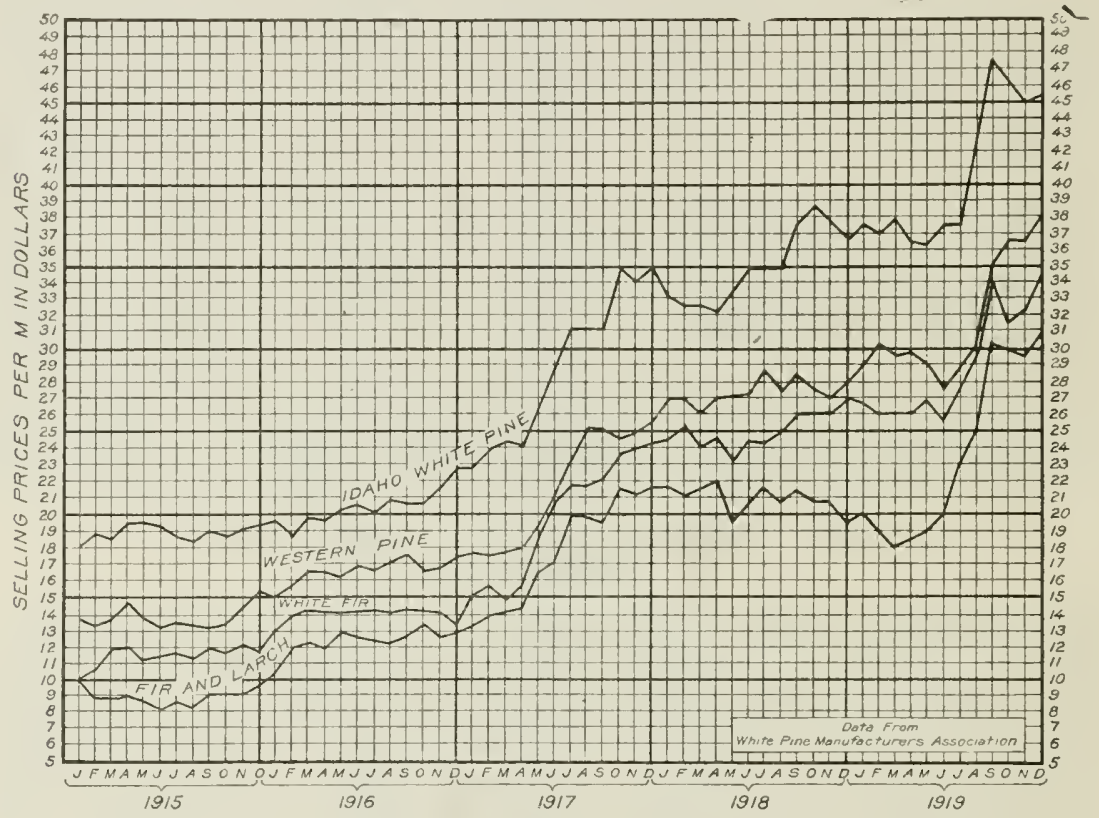

FIGIIQ FLUCTUATION OFAVERAGE MILL RUN LUMBERPRICES ON IMPORTANT SPECIES

FOB MILL IN THE INLAND EMPIRE

The eurves presented herewith in figure 11 show the variation of prices from 1908 to May, 1916, on No. 2 and No. 4 common white pine, No. 2 and No. 4 common western pine, No. 3 common cedar, and No. 1 common fir and lareh. It is the intention to show merely the general ups and downs of the market and not the absolute price returns to the mill. Each sale of these items was plotted on cross-section paper. It was found that the dots representing the sales of each item fell in a comparatively broad band. This indicates that on a given day the prices received for the same item generally vary widely. In some cases it was found that for a given day the maximum price for an item was as much as 100 per cent higher than the minimum, and usually the maximum was at least 25 per cent higher than the minimum. Wide variations oceur even in the sales of the same company, for the sales manager accepts or turns down a proffered purchase for a variety of reasons such as the average price on the whole order, the effect of filling the order upon yard stocks, the credit of the individual making the offer, etc. 
TABLE 9.-Selling price of lumber per thousand, all widths, for 1913, 1914, 1915, 1916, 1917 , and 1918, compiled from data furnished by the Lumbermen's Information Bureau of the Western Pine Manufacturers' Association.

\begin{tabular}{l|l|l|l|l|l|l|l}
\hline Grade & 1913 & 1914 & 1915 & 1916 & 1917 & 1918 & 1919 \\
\hline
\end{tabular}

IDAHO WHITE PINE

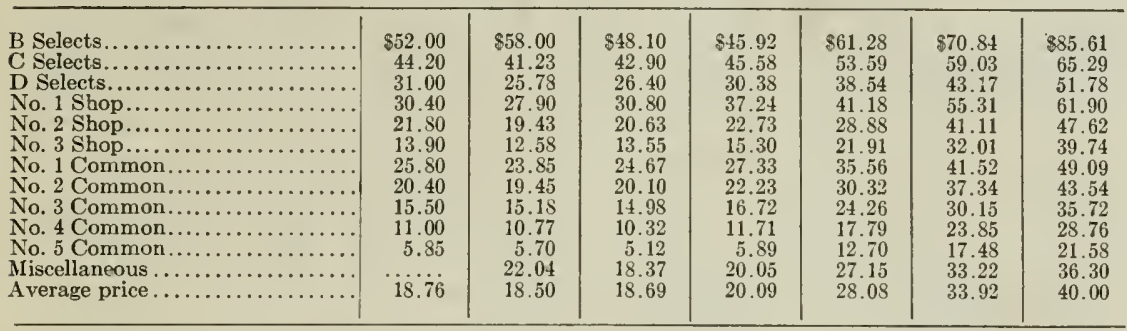

\section{WESTERN PINE}

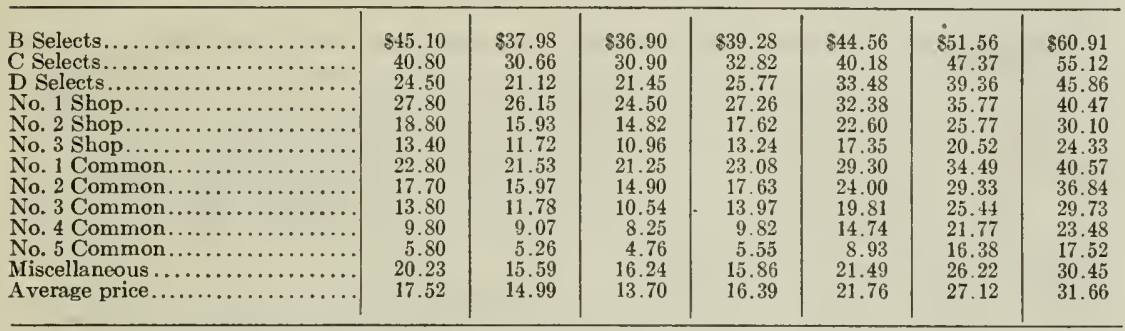

\section{DOUGLAS FIR AND LARCH}

\begin{tabular}{|c|c|c|c|c|c|c|c|}
\hline No. 3 Common........... & 11.11 & 10.02 & 9.35 & 12.07 & 15.23 & 20.44 & 23.02 \\
\hline No. 5 Common.... & 4.99 & 4.75 & 5.00 & 4.03 & 8.01 & 14.27 & 17.09 \\
\hline No. 1 Dimension.... & 12.84 & 10.48 & 8.53 & 12.55 & 16.59 & 21.36 & 22.63 \\
\hline No. 2 Dimension...... & 8.54 & 7.51 & 5.50 & 6.89 & 14.10 & 17.57 & 18.43 \\
\hline No. 3 Dimension......... & (a) & 6.06 & 5.52 & 5.07 & 9.00 & & 13.80 \\
\hline Miscellaneous.......... & & & & 11.50 & 20.25 & 29.49 & 30.01 \\
\hline Average price........... & 12.72 & 10.43 & 8.83 & 12.26 & 16.61 & 21.18 & 23.25 \\
\hline
\end{tabular}

(a) Included with No. 1 Dimension.

ENGELMANN SPRUCE

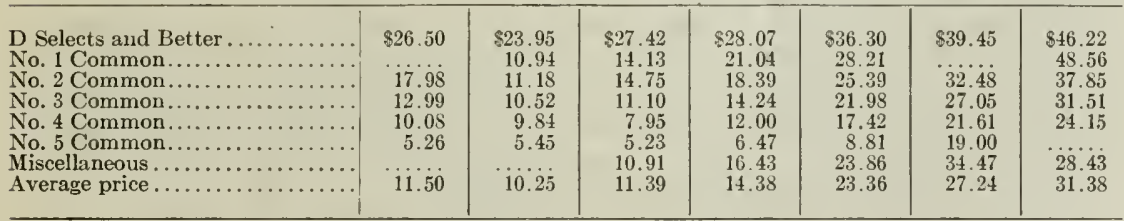

\section{WHITE FIR}

\begin{tabular}{|c|c|c|c|c|c|c|c|}
\hline No. 3 Common and Better ....... & $\$ 13.26$ & $\$ 12.07$ & $\$ 11.81$ & $\$ 14.88$ & $\$ 20.36$ & $\$ 21.56$ & $\$ 30.20$ \\
\hline
\end{tabular}


TABLE 9.-Selling price of lumber per thousand, all widths, ete-Continued.

\begin{tabular}{l|l|l|l|l|l|l|l}
\hline Grade & 1913 & 1914 & 1915 & 1916 & 1917 & 1918 & 1919 \\
\hline
\end{tabular}

CEDAR

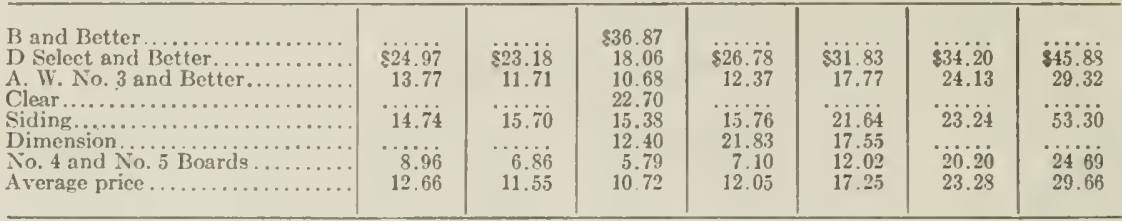

IDAHO WHITE PINE LATH

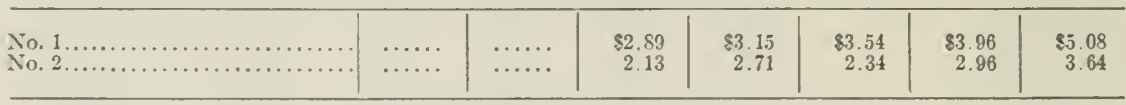

WESTERN PINE LATH

\begin{tabular}{|c|c|c|c|c|c|c|c|}
\hline $\begin{array}{l}\text { No } 1 \\
\text { No. } 2 \ldots \ldots \ldots \ldots \ldots \ldots \ldots \ldots \ldots \ldots \ldots \ldots \ldots \ldots \ldots\end{array}$ & $\cdots \cdots$ & $\ldots \cdots$ & $\begin{array}{r}\$ 2.55 \\
1.72\end{array}$ & $\begin{array}{r}\$ 2.68 \\
2.05\end{array}$ & $\begin{array}{r}\$ 3.31 \\
2.00\end{array}$ & $\begin{array}{r}\$ 3.50 \\
2.22\end{array}$ & $\begin{array}{r}\$ 4.21 \\
2.89\end{array}$ \\
\hline
\end{tabular}

Although price lists have been regularly published in the Inland Empire, their main object has been to serve as a guide to salesmen and especially to aid them in making the proper allowance for freight rates, since the price quoted includes delivery to the purchaser. The price list represents the concensus of opinion as to the relative, not actual, value of various species, grades, widths, lengths, and patterns. At all times concessions are made below the price list of various amounts on different items. These concessions in turn have been listed on "discount sheets," which change rather rapidly with market and lumber stock conditions, while the general price list remains fixed for long periods.

The concession lists serve chiefly to record approximately the average existing price. The word average is used here because no definite price is established, such as that for No. 1 northern wheat, prime steers, or heavy hogs on the Chicago market. Inland Empire lumber is not handled or quoted by any central lumber exchange; the price is fixed at each individual plant by the sales manager. It is governed largely by supply and demand in which the yard stocks, financial condition, and policy of the individual plant play their part. It is of course influenced to a greater or less extent by information obtained by the lumbermen cooperatively; and it unquestionably reflects from time to time a degree of joint action resulting from the interchange of going prices and discussions of the market. Such action is undoubtedly more in evidence when the market is strengthening and operators are seeking to make the most of a farorable situation than at other times.

In figure 12 the price of lumber is compared with some other important commodities. One notes the tendency of lumber to lag in following the general ups and downs of the other curves, which represent steel plates, beams and bars, pig iron, Babson's average of 10 commodities other than foodstuffs, and coke. For comparison with these, several of the lower grades of lumber were thrown together, and also two of the higher grades, using items which has been chosen for investigation and which had approximately the same price.

As compared with lumber, the prices of other commodities move upward or downward in most cases rather rapidly. Lumber lags considerably behind the other commodities, owing apparantly to the lack of information on prices and yard stock conditions in the producing territory, the lack of an organization in the industry which would give this sort of information (now available to those engaged in many less important industries), failure to use intelligently such data as are available, and lack of knowledge of general business conditions.

During the periods of higher prices the principal shipping movement is over before prices reach the highest point. This lag, however, is partly due to the fact that the quantity of lumber needed by the market changes relatively slowly with changing business conditions. Glance for instance at the monthly lumber shipments in figure 12. It will be seen that while one of the heaviest shipments occurred in midsummer of 1912 the high price for lumber was not obtained until the following summer, although the prices of other commodities responded much more promptly to the general "good times." The prices of spccific lumber items indicate more or less of a pendulum action rather than the delicate adjustment brought about by 
full knowledge of the facts and intelligent use of this knowledge in forecasting the market. For instance, late in 1914 the demand for $\mathrm{No} .2$ common white pine became quite strong. The sales managers were anxious to move anything that they could and sold this item in solid carloads in some cases. Suddenly they awakened to find

FIGURE 12 .
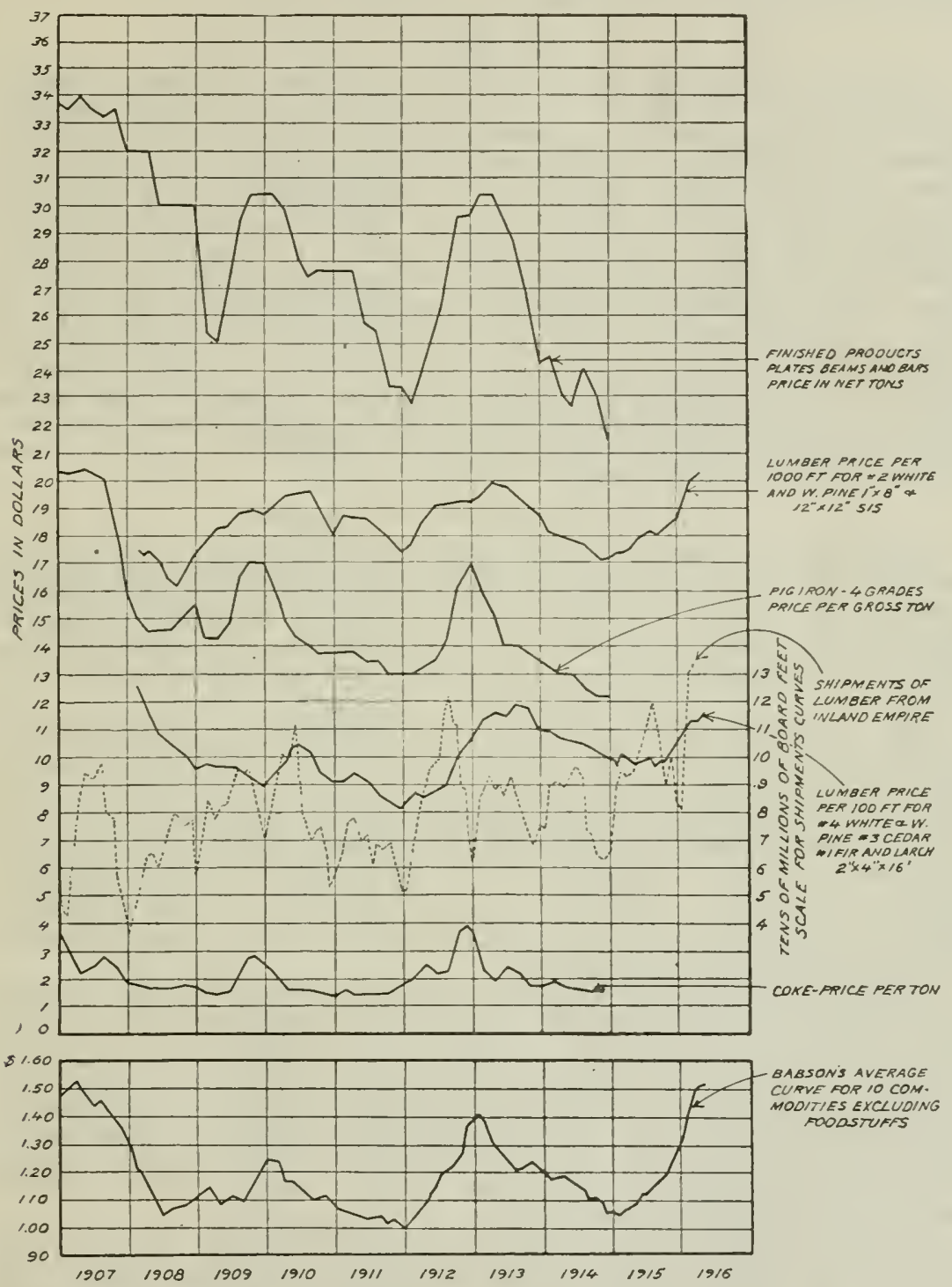

BABSON'S AVERAGE

CURVE FOR 10 COM. MODITIES EXCLUDING FOODSTUFF

COMPOSITE CURVES SHOWING FLUCTUATION OF LUMBER PRICES IN THE INLAND EMPIRE COMPARED WITH OTHER COMMODITIES

the item practically cleaned out of Inland Empire yards; they then undertook to balance their stocks by raising the price materially.

Lumber prices are made largely by the purchaser. Owing to the pressure to sell and to cut prices, on the part of salesmen representing neighboring firms in the Inland Empire; owing also to serious competition from other producing regions and 
from various substitutes for lumber, great efforts are mate to secure buyers. With so many competing offers coming to the purchaser from all directions, he occupies the strategic position and simply has to choose the best quotations. $\Lambda$ s the saying is, lumber was formerly bought but is now sold. In other words, earlier in the history of the eountry the users of lumber were anxious to obtain it and went to the manufacturer to buy. Now the situation is generally reversed.

\section{LOG PRICES}

As indicated previously, only approximately 20 per cent of the timber is logged by men who do not also mill it. Most of this timber is contracted to the manufacturer before it is eut, and but a very small quantity is sold in the open log market. However, small markets do exist in various places; that is to say there are well known eurrent prices which companies in the different regions are willing to pay for logs. The log markets, such as they are, show ups and downs in conformity with the general condition of the lumber business. They also fluctuate with climatic conditions, which may interfere with logging or milling. For example, in the winter of 1914-15 there was less than one-third of the normal snowfall in the Bitterroot and Coeur d'Alene Mountains. The spring was an early one and the snow went off early. It was anticipated that a shortage in white pine logs would be felt in Cocur d'Alene Lake, owing to failure to get out various drives. Some predicted that white pine logs ordinarily selling for $\$ 13$ per thousand feet would reach $\$ 15$. While the shortage did not materialize, the situation illustrates the effect of elimate on log prices, which may sometimes be more important than general market conditions. Table 33 (Appendix) indicates the prices of logs during the last few years in various waters of northern Idaho and western Montana.

\section{FINANCIAL CONDITION OF TIIE INDUSTRY}

During the six-year period ending with 1914, a group of companies cutting 59 per cent of the lumber output of the Inland Empire and including the largest and best managed mills, earned on the average 1.06 per cent on all of their eapital employed, borrowed and unborrowed, exclusive of their profits on stumpage investments. Aside from the profit on timber, these concerns failed to earn enough to pay 6 per cent on their indebtedness in four our of the six years and on the average for the period.

Table 10 shows the financial condition of the leading lumber companies in the Inland Empire during the 6 years ending with 1914. The companies included are all manufacturers; none of them are merely timber owners. Timber ownership as well as the operating part of the business is included in the statement. There are also included such side issues to the main business of manufacturing lumber as are common in the industry-boarding houses, commissaries, stores, boom companies, retail lumber yards, etc. These secondary enterprises are usually more profitable than the main business, when tested by the percentage earned on the capital employed. One company made about enough on a small store to off set its losses in manufacturing lumber. On the whole, the net earnings from secondary enterprises amount, perhaps, to $\$ 200,000$ annually.

The average quantity of timber owned by these companies will furnish a supply of logs for approximately 21 years without allowing for overrun, or for about 28 years on the basis of a 32 per cent overrun. Some companies own from 50 to 75 years' supply at the rate at which eutting is now going on. Some companies own practically no timber, or so little that it could be cut out in less than one year if the company were to operate in it exclusively. The companies included in this group cut approximately 5,655 million feet in the 6 years, or 59 per cent of the total cut of about 9,600 million feet in the region during that time. These mills were operating on the average to the extent of 48 per cent of their theoretical maximum capacity, and the ratio did not vary much during the 6-year period.

The "paid up capital stock" includes cash and property such as timberland and plants paid in for shares; in all eases so far as known the property paid in has been put in at a reasonable valuation. The "capital employed" includes paid up capital stock and borrowed capital; it does not include earned surplus retained and used in the business. It would have been desirable to include earned surplus if the figures had been readily available; the omission does not, it is believed, materially reduce the "capital employed." At any rate it is felt that the broad purposes of the investigation are fulfilled by using "capital employed" as defined above. The exact financial status could be determined, if at all, only by a detailed audit of the affairs of each individual company through its entire history and by a revaluation of its assets.

The debt of the companies here included increased steadily during the period. In 1909 the debt amounted to 28.7 per cent of the paid up capital stock, and in 1913 


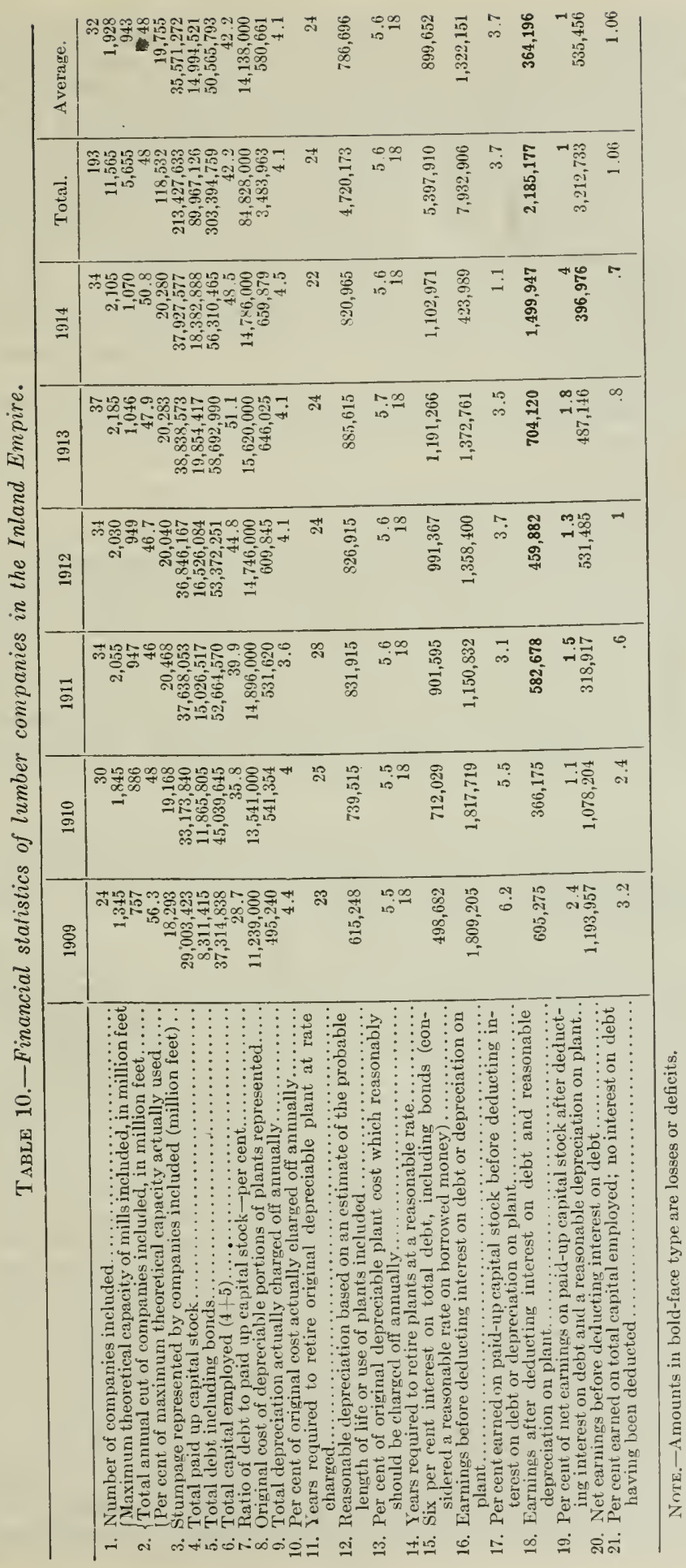


it had increased to 51.1 per cent. $\Lambda$ slight decrease is shown in 1914 ; but it is more apparent than real, owing to the absence of records from some companies in 1914 which were represented in 1913. The debt of these companies is made up as follows: in 1914, with a total debt of approximately $\$ 18,383,000$, there was in bonds ontstanding $\$ 3,416,000$, bills payable $\$ 11,725,000$, accounts payable $\$ 701,000$, land contracts $\$ 312,000$, lumber contract advances $\$ 185,000$, mortgages based on plant and plant site only $\$ 113,000$, and unclassified $\$ 1,928,000$. Alout three-fourths of the unclassified debts are bills payable. About two-thirds of all the bills payable consist of stockholders' notes, which amount to somewhere in the neighlorliood of $\$ 8,000,000$. The interest rate on the bonds varies from 5 to 7 per cent, exclusive of brokerage and discounts allowed in floating the issues, which frequently inerease materially the rate of interest on the money actually secured. The interest on bills payable varies from 4 to 8 per cent. In many cases the debt of the companies was increased rather regularly by meeting interest due on stockholder's notes by issuing new notes; some companies paid practically no interest on such indebtedness excepting by issuing new notes.

In this table stumpage is figured as a cost at the rate at which it is charged on the books of the companies included. As previously shown, a considerable profit is earned on the stumpage investment when timber is charged to operation at such rates.

Accounts receivable average approximately 30 per cent of the annual sales, or the equivalent of 3.6 months shipments.

The item of depreciation requires some explanation. In line 9 of 'Table 10 depreciation is set down as actually charged off by the companies represented. There is, however, a very great variation in the rate at which property subject to depreciation is written off. Some companies are charging off their depreciable assets at a rate which will eliminate them in ten years or even less; on the other hand, some are charging off no depreciation whatever. There are all stages between these extremes; and there is frequentiy a material variation from one year to another in the rate at which depreciation is charged off by the same individual company. The theory upon which many managers work is, "Wait until everything else is taken care of at the end of the year, and see if there are any earnings left from which to deduct depreciation. If there are no earnings, charge no depreciation; if there are considerable earnings, charge enough depreciation to cover the curreut year and other years also.'

Many have not written off any depreciation, hoping that conditions each succeeding year would be good enough to charge off some depreciation without showing a loss. This appears to be no uncommon situation in the business world in general. It is stated that, of 66,000 corporations in the United States doing a business of over $\$ 100,000$ annually, 30,000 charge off no depreciation.

The average rate of depreciation written off by all the companies represented in 'Table 10 was 4.1 per cent, which would wipe out the depreciable assets in 24 years. After careful consideration of the plants in question, what is considered a reasonable operating life was fixed for each in view of the time that the plant had already been running, the available supplies of timber, and the favorableness of its site from a manufacturing standpoint as to physical conditions, labor conditions, accessibility of timber supplies, etc. In the experience of the region it is frequently found that, while a mill may still be in usable condition a site is available nearer the timber which will reduce operating costs. In this case it may be profitable to abandon the old plant with a salvage value representing ten per cent or less of its original cost. In other cases a new company may buy out an existing operation, decide that the old plant does not suit its requirements, and build a new one.

Such things have taken place so many times that it seems unsafe to predict a very long life for any sawmill. In spite of this uncertainty, however, reasonable operating lives have been predicted, varying from 25 years in the case of some plants to 10 years in the case of others. The weighted average is 18 years, which requires that 5.6 per cent of the plant investment be charged off as depreciation annually.

The rate of interest on debts is set down at 6 per cent, which is exceedingly close to the average rate of interest paid.

Line 16 of Table 10 gives the earnings of this group of companies without deductions for interest on indebtedness or plant depreciation, amounting to approximately $\$ 1,322,000$ as the average annual return throughout the 6 -year period. Line 17 shows that this amount is an average earning of 3.7 per cent on the paid up capital during the 6 -year period. Line 18 shows the earnings after deducting 6 per cent interest on the debts and a reasonable depreciation on the plants. In 1909 and 1910 there was something left over in the form of net earnings after dechucting both interest and depreciation. Subsequently, however, there were in the aggregate no net earnings as thus defined, but a loss varying from $\$ 460,000$ in 1912 to $\$ 1,500,000$ in 1914 
and averaging about $\$ 364,000$ for the 6-year period. As is shown in line 19 , this is equivalent to an average annual loss of 1 per cent on the paid up capital stock.

Leaving interest on the debt out of account in order to get at the earnings of all of the capital employed in the business, line 20 shows an average annual earning of about $\$ 536,000$. This is equivalent to 1.06 per cent on all of the capital employed; in one year, 1914, this item was also a minus quantity. In other words, during the 6 -year period ending in 1914, these companies earned on the average 1.06 per cent on all the capital in use, borrowed and unborrowed, exclusive of their profits on stumpage investments, and failed to earn enough to pay interest on their indebtedness. The profits realized from stumpage investments are discussed in the first part of this report and also in the following section.

There appears to be a fecling on the part of many lumbermen that their industry is peculiarly unfortunate in the matter of profits. Stumpage ownership and lumber manufacture have been closely united; during the years prior to 1907 stumpage values increased enormously throughout the country. This put lumbermen in the habit of expecting large profits. Now that conditions have radically changed, most lumbermen are finding difficulty in readjusting their ideas of profit; and the feeling is common that most other industries are doing much better. It has been stated, however, that of the 250,000 corporations in the United States 100,000 have no net income, and that 90,000 more have a net annual income of less than $\$ 5,000$ each. The owner of the average farm is said in the long run to own no more than a job, as far as income from the investment is concerned. It is reported also that the prices of soft coal and crude oil barely return the cost of production.

While the lumber industry may be no worse off than many other important industries, it is believed that up to the middle of 1915 conditions were becoming worse so rapidly as to threaten a serious demoralization of the industry. In 1916, however, better market conditions gave a breathing spell with a chance to put the industry in much better working condition and to overcome certain of its weaknesses.

A very few companies in the Inland Empire have paid moderate dividends consistently; some have paid one or two dividends; but most of the companies have paid none at all. Most of the concerns are reasonably well supplied with capital; it is not more capital that is needed, but less of it in the form of borrowed money. With a profit margin as narrow as that shown to exist, any considerable amount of debt is a great handicap to success. New organizations planning to start in the business should study the situation very thoroughly from this standpoint.

\section{INTERRELATION OF STUMPAGE AND OPERATING PROFITS}

For the group of large companies discussed under the preceding heading, the total margin between the sale price of lumber and the actual cost of production, leaving out stumpage, profits, and interest, may for 1914 be divided in any of the following ways:

(1) An earning of 12 per cent compound interest on the stumpage investment and of one-tenth of one per cent simple interest on the operating investment;

(2) An earning of 6 per cent compound interest on the stumpage investment and of 3.3 per cent simple interest on the operating investment; or

(3) No earning on the stumpage investment (with timber charged at its actual cost) and a return of 5.1 per cent simple interest on the operating investment.

Table 10 shows, as the average for 6 years ending with 1914, a total investment of about $\$ 50,600,000$ in approximately 19.5 billion feet of stumpage, mill plants, working capital, etc., in operations cutting about 940 million feet of lumber per year. On the same basis an investment of about $\$ 33,400,000$ would be required for the remaining cut in the Inland Empire of $6 C 0$ million feet, together with 13.9 billion feet of stumpage, if the ratio of standing timber to lumber cut were the same. Thus there would be a total investment of $\$ \$ 4,000,000$ carrying 33.7 billion feet of stumpage and providing the operating plant and capital for a yearly cut of about 1,600 million feet. This leaves 58.1 billion feet out of the total of 91.8 billion of privately owned stumpage in the Inland Empire still to be accounted for. At an average outlay of $\$ 0.95$ per thousand feet, no interest included, this additional timber represents an investment of about $\$ 55,200,000$. Hence the total investment of the lumber industry in the Inland Empire is somewhere near $\$ 140,000,000$. About $\$ 47,000,000$ is invested in the lumber manufacturing end of the business, and the rest in stumpage. If the stumpage were put in at the rate at which it was charged off in 1914 on the books of the operators, the total investment in the industry would be increased to about $\$ 330,000,000$.

As indicated previously, approximately 40 per cent of the logs are driven. This necessitates a considerable investment in labor and supplies which must be carried from the time the season's supply of logs is cut until it is sawed at the mill. With 
railroad logging, timber can ordinarily be taken from the stump to the saw mill in about a month; but where driving is resorted to the timber is felled during the summer and fall, and the logs are not usually delivered at the mill until the following spring, and are not all sawed before winter. On the average, it is estimated that 10 months elapse between cutting the $\log$ and sawing it into lumber where driving is used as a principal method of transportation.

$\Lambda$ weighted average thus indicates that an investment in logs is carried for an average period of 4.6 months. If approximately $\$ 6$ per thousand feet, lumber tally, is invested in the log before it reaches the mill, for each million feet of annual output a capital of approximately $\$ 2,300$ is required for the log supply. The amount so invested, of enurse, fluctuates with the scason of the year. This does not include the money expended in purchasing timberland.

Table 10 shows that the original cost of the portions of plants producing an average cut of 943 million feet which are subject to depreciation was $\$ 14,138,000$; the nondepreciable portions of the plants would bring this amount to about $\$ 15,000,000$. For each million feet of lumber eut annually the plant investment is thus about $\$ 15,900$. It has been shown that the average inventory is 78 per cent of the yearly shipments, or 73.5 per cent of the annual cut. For each million feet of annual eut there are 735,000 feet of lumber in yard stocks. At $\$ 9.50$ per thousand feet (stumpage not included) this amounts to about $\$ 7,000$. Bills and aceounts receivab), averaging approximately 30 per cent of the annual sales, amount to about $\$ 4,200$. Thus the total investment engaged in the manufacture of lumber amounts to about $\$ 29,400$ for the average million feet of lumber cut annually.

The rates at which stumpage is being charged off on the books of the operating companies as the timber is cut include a profit above its original cost. These profits varied from 4 to 6 per cent compound interest in the case of companies which bought their stumpage early at a low price but were still charging it off at only about a dollar per thousand feet, up to as high as 20 to 25 per cent compound interest in the ease of companies which also bought their stumpage at a low figure in the early days but were charging it off at as high a figure as $\$ 5$ in 1914.

Table 11 shows for different years from 1909 to 1914 what profit was obtained from timber investments under various methods of accounting, and the corresponding earnings on the operating investment. Stumpage for which there was an actual outlay of $\$ 0.95$ per thousand feet, in 1914 , would have a capitalized value of $\$ 1.70$, if 6 per cent compound interest were added. In that year the stumpage eut was being charged off at $\$ 3.06$. This figure gave an earning of 12 per cent compound interest on the actual outlay for timberlands. One-tenth of one per cent simple interest was earned on the capital invested in lumber manufacture, if the stumpage item is so handled.

TABLE 11.--Relation of profits on stumpage and operating investments.

\begin{tabular}{|c|c|c|c|c|c|c|}
\hline & 1909 & 1910 & 1911 & 1912 & 1913 & 1914 \\
\hline $\begin{array}{c}\text { Actual outlay for stumpage cut (no interest } \\
\text { included). Timber estimate basis.............. }\end{array}$ & So. 85 & $\$ 0.87$ & \$0.88 & $\$ 0.90$ & $\$ 0.92$ & $\$ 0.95$ \\
\hline 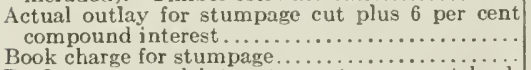 & $\$ 1.18$ & $\begin{array}{l}\$ 1.27 \\
\$ 3.96\end{array}$ & $\begin{array}{l}\$ 1.36 \\
\$ 3.84\end{array}$ & $\$ 1.47$ & $\$ 1.58$ & $\begin{array}{l}\$ 1.70 \\
\$ 3.06\end{array}$ \\
\hline $\begin{array}{l}\text { Profit, compound interest, on stumpage at book } \\
\text { charge, per cent ............................. }\end{array}$ & 32 & 25 & 21 & 17 & 13 & 12 \\
\hline $\begin{array}{l}\text { Earnings, simple interest, on operating capital, } \\
\text { with stumpage at book charge, per cent ......... } \\
\text { Earnings, simple interest, on operating capital. }\end{array}$ & 6.2 & 4.9 & 2.3 & 3.0 & 2.7 & .1 \\
\hline $\begin{array}{l}\text { Earnings, simple interest, on operating capital, } \\
\text { with stumpage at actual outlay plus } 6 \text { per cent } \\
\text { compound interest, per cent...................... }\end{array}$ & 13.5 & 11.3 & 8.1 & 7.9 & 5.8 & 3.3 \\
\hline 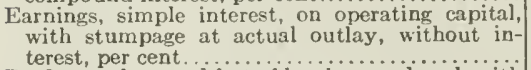 & 14.3 & 12.3 & 9.3 & 9.2 & 7.4 & 5.1 \\
\hline $\begin{array}{l}\text { Profit per thousand feet of lumber produced, with } \\
\text { stumpage at book charge........................ } \\
\text { Profit per thousand feet of lumber produced, with }\end{array}$ & $\$ 0.43$ & $\$ 0.60$ & $1-\$ 0.18$ & $\llcorner \$ 1.22$ & $\$ 0.07$ & $\$ 0.27$ \\
\hline 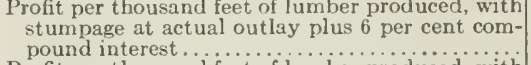 & $\$ 2.76$ & $\$ 2.64$ & $\$ 1.70$ & $\$ 0.34$ & $\$ 1.0 \mathrm{~S}$ & $\$ 1.30$ \\
\hline 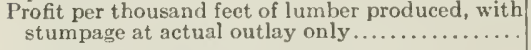 & $\$ 3.01$ & $\$ 2.94$ & $\$ 2.06$ & $\$ 0.77$ & $\$ 1.58$ & $\$ 1.87$ \\
\hline
\end{tabular}

1 Loss.

Charging stumpage at its actual cost plus 6 per cent compound interest gives an earning of 3.3 per cent simple interest on the operating capital. Charging stumpage at its actual cost alone gives an earning of 5.1 per cent simple interest on the operating capital. In 1914 , if stumpage is eredited with the $\$ 3.06$ actually eharged on the books, a profit of $\$ 0.27$ was earned on each thousand feet of lumber sold. Reducing 
the stumpage charge to its actual cost plus 6 per cent would leave a profit of $\$ 1.30$ per thousand feet of lumber; while placing the stumpage charge at its actual cost only would bring this profit up to $\$ 1.87$. In this year, then, the earnings could be so divided that 6 per cent would be earned on the stumpage investment and there would be left a profit of $\$ 1.30$ per thousand feet of lumber, equivalent to 3.3 per cent simple interest on the manufacturing investment. The data given in Table 11 are presented graphically in figure 17 (Appendix).

The figures just given are presented to illustrate the interrelation of stumpage and operating profits under different conceptions as to how each should be determined or how the total earnings should be divided between these two elements. As indicated in discussing the "Value of Timber," the correct method is believed to be, not to capitalize stumpage at an automatic interest rate, year hy year, but to base its valuation (and hence the profits earned upon its original cost) upon the margin between cost of production and selling price, after deducting a moderate manufacturing profit. To even off the frequent ups and downs of temporary dura-. tion in the lumber market, some such interval as five years might be used for this purpose. Then if 5.1 per cent be regarded as a reasonable profit on the manufacturing iuvestment in 1914, the average stumpage in the Inland Empire was worth what it cost and earned no profit in that year. Or if 3.3 per cent on the operating investment be regarded as sufficient, the stumpage earned a profit of 6 per cent compound interest.

\section{HOW CAN THE LUMBER INDUSTRY BE MADE MORE STABLE?}

\section{A SUMMARY OF THE PRESENT SITUATION}

It is well to remember that the excessive burden of privately owned stumpage is by far the most important factor tending to prevent stability in the industry. There is strong pressure to convert stumpage into lumber in order to liquidate the stumpage investment and utilize the plant investment. There are several reasons for this pressure. The total debt of the industry in the Inland industry on timber and mills is about $\$ 40,000,000$. It takes about $\$ 1.50$ for every thousand feet of lumber produced each year to take care of the interest on this debt. Taxes on timber and plant amount to about $\$ 1.25$ for each thousand feet of lumber produced annually. Similarly, timber land administration adds $\$ 0.11$ and timber protection $\$ 0.08$. To this must be added approximately $\$ 1.59$ for management and office salaries, insurance, legal expenses, and depreciation on plant.

These outlays can be recovered ultimately only through the manufacture of lumber. From the standpoint of the industry viewed as a whole, they can be said to be equivalent to a fixed charge of $\$ 4.53$ per thousand feet on the present output of the region.

If the cut is reduced, the fixed charge per thousand feet will necessarily increase, for these expenses continue regardless of cutting. The natural tendency is to cut as much lumber as possible each year, so that the fixed charge per thousand feet will be at a minimum. From an operating point of view it is entirely feasible, as we have seen, to increase the cut materially, since most mills are operated below their capacity. It is highly desirable to keep mills in continuous operation, even in the dullest times, in order to preserve the personnel organization. The financial standing of a company suffers greatly if it changes from a "going concern" to one that is inactive. There is also a real responsibility, which is generally recognized by the management, to continue operation for the sake of dependent communities.

The following conclusions and suggestions are based upon frank discussions with many different lumbermen of the region, upon knowledge gained by the writer in a number of years of local experience in the work of the Forest Service, which has touched closely many phases of this investigation, and upon all of the data and facts brought to light by the investigation itself. The personal judgment of the writer necessarily affects the conclusions and suggested remedies which follow. Few of these suggestions are original. Most of them have been in the minds of one or another of the lumbermen in touch with the situation. It is attempted here merely to bring together the most reasonable conclusions and suggestions, both for bettering the industry itself and for meeting the larger public interests involved.

\section{A BETTER UNDERSTANDING OF THE SITUATION BY THE PUBLIC}

The public at large has not realized that it is interested in the welfare of the lumber industry. It has suspected that various forms of restraint upon trade have arbitrarily raised the price of lumber, and that huge profits have been obtained by stumpage owners and li mber manufacturers. This report has shown that large profits have been made by some investors in timberland in the Inland Empire, while some have lost money. The study has shown also that the profits from the manu- 
facture of lumber by itself, in the Inland Empire cluring the 6 years ending with 1914, were sinall. 'The country as a whole, and especially the industrics and people in the regions in which the lumber industry itself is of the greatest importanee, have not realized how the unstable conditions in this business cause a waste of the nation's timber resourees; nor have they realized fully the dependenee of the railways, farmers, bankers, storekeepers, eities, etc., upon this great industry. They have not appreciated the fact that a sick industry in their midst has been the cause of some of their own pains.

There is great need that the lumber industry be put on a unore stable basis. Its present unsoundness injures both the eapital and the labor engaged and the whole economic life of the region. Such a condition is harmful to the interests of the consumers of lumber in the long run because premature cutting brings about a waste of resourees which will make itself felt sooner or later in a shortage of supply and higher prices for forest products.

It is belicved that the lumber industry might well cultivate the attitude of the most progressive public service corporations throughout the country, as expressed in the slogans, "the public be served" and "the public be informed." Lumbermen should take the public into their confidence and show clearly at frequent intervals just what is the enndition of affairs in their inclustry. This should be done through statistics published at regular intervals showing mill capacity, cut, itemized costs of production, prices obtained, payments to the railroads in the form of freight, and the profits earned. Undoubtedly, as a number of operators believe, it would be helpful in bringing about a more friendly spirit between the industry on one side, and the labor cngaged in the industry and the public, on the other, for each company to publish a statement annually showing its financial condition.

The public should be given a clear understanding of the industrial side of the conservation problem; how the utilization of short length boards where they will do as well will reduce waste; how the use of low grades in places where they are serviceablo will tend to closer use of standing timber; how the choice between lumber and substitutes can be made with the greatest advantage to the user, putting lumber of the right kind in places where it can be employed most advantageously and using substitutes where they are economically best; and how the use of timber in the woods, the husbanding of the country's timber resources, is affected by the current conditions in the industry. The lumbermen, the laborers in the industry, the men of other local industries, the consumers of lumber, and the public in general, should understand the importance of using the virgin timber and the timberland resources which produced it and are capable of reproducing it in such a way that future supplies may be assured while present needs are met. It should be clearly realized that the "conservation idea" is an irresistible trend of the times which is mainly concerned with human betterment, and that to cooperate with it is the wisest policy.

The public should understand the problems of the private owners in handling cutover lands and the difficulties which confront him in attempting far-sighted plans of reforestation. The public can be best informed through statements gotten out at frequent intervals by the lumbermen; but these statements should be supplemented by data prepared by some governmental agency, so that the public at large will be convinced that the information which it is obtaining is of an unbiased and authoritative nature.

\section{WHAT THE GOVERNMENT CAN DO}

With some lumbermen it has been the custom to charge all of their troubles to the government and to believe that if the government would only let them alone or pass laws favorable to their industry, the situation would be greatly improved. But the government must approach the question from the standpoint of the welfare of the whole people. By "government" is meant all the public agencies, Federal, State, and local, which come into contact with the lumber industry.

\section{THE TARIFF UNIMPORTANT.}

The tariff has come in for a good deal of discussion by individual lumbermen and by trade journals. The most intelligent opinion in the Inland Empire is to the effect that the tariff has had extremely little influence upon the lumber industry of this region, whatever may be its influence in other parts of the country.

\section{REGULATION OF PRICE OR PRODUCTION}

Many lumbermen feel that the Sherman anti-trust law should be so modified as to permit them to organize with the object of regulating prices and, a necessary feature of price regulation, of regulating lumber production. Owing to the economic conditions existing in the industry and to the individualism of the lumberman, such 
a change in the law would probably be useless as a means of stabilizing the industry unless accompanied by effective government regulation. However, some Federal agency, such as the Federal Trade Commission, should be definitely authorized to advise lumbermen on how they may cooperate more effectively in giving their industry greater stability.

\section{TAXATION OF TIMBERLANDS.}

The lumber industry must, of course, contribute to the support of government on an equitable basis in comparison with other industries; on the other hand, the government must, if it is wise, take fully into account the character of the industry and its ability to pay taxes. It is folly to tax timberland so heavily or in such a manner as to force the destruction of the resource taxed, and thereby destroy the source of future comminity income as well as of community industries. The present general property system of taxation tends to do just this. It is highly desirable that some equitable form of the income tax principle be applied to timberland. It would be a conserving rather than a destructive force and would eliminate the pressure to liquidate timb rland investments so far as it is caused by taxation.

\section{STATISTICAL REPORTS.}

The government should make arrangements to cooperate with the industry in gathering statistics of all kinds regarding its condition, financial and otherwise, for the purpose of presenting unbiased statements to the public at regular intervals. Such information will also be of great value to the lumbermen themselves.

\section{THE DISPOSAL OF PUBLIC TIMBER.}

The policy followed in disposing of National Forest timber has an important bearing upon the lumber industry. Uncertainty on this score, with the fear that large quantities of public stumpage might be forced upon the market, has been a factor in the pressure to cut private stumpage. As far as National Forest timber influences the situation, it should be a stable and conserving factor, not a demoralizing one or one which adds to the tendencies inherent in the industry to use standing timber wastefully. The definite establishment of such a policy in the administration of National Forest timber with the concurrence of all of the public agencies involved, when coupled with a general timber policy in which the government cooperates with the industry in stabilizing the holding of private timber, will be of material aid in putting the industry in the Inland Empire upon a sounder footing.

The outlines of such a National Forest timber policy are given in the summary report of the study of the lumber industry conducted by the Forest Service. ${ }^{1}$ Its cardinal points are to sell National Forest stumpage only for immediate manufacture, eliminating altogether the element of stumpage speculation, at conservative appraisals which represent its full value, not as determined by the latest rise or fall in the lumber market, but by all its movements over considerable periods, and to purchasers adequately financed to conduct successfully the logging and manufacturing enterprises contemplated. The government should not force the cutting of its timber when not needed by economic conditions, but should supply all logical and well founded demands which come to the Forests in the course of the development of the lumber and other industries in the rrestern states. The same principles might well govern the disposal of timber under other forms of public ownership or control.

\section{EXTENSION OF PUBLIC OWNERSHIP OF TIMBERLAND.}

The liberal and ill adjusted land laws of the United States in times past allowed huge areas of timberland to pass into private ownership. Now a strong desire to liquidate private timber holdings unquestionably exists. The private owner now sees no profit which will justify his holding timberlands for the production of wood after cutting the present merchantable crop. He has no intention of holding such lands indefinitely. If for nothing else he plans to sell most of them for grazing.

Here in the Inland Empire is a great national asset in the form of approximately $6,000,000$ acres of privately owned land best suited permanently to the production of timber. It would be a material economic loss to have this land turned over to unrestricted private grazing, because the land is needed in forest both to supply the nation's timber needs and to protect watersheds. In addition, about 400,000 acres suitable only for summer grazing or protection forest, also requires a kind of management which it is not likely to receive in private ownership.

It is strongly felt that one of the most important features of a permanent solution of the problem, although necessarily one which could be put into effect 'only gradually, would be the adoption of a policy on the rart of the $F \in d$ ral Government of

1 "Some Public and Economic Aspects of the Lumber Industry," by W. B. Greeley. 
aequiring cutover lands more valuable for the production of timber than for other purposes within areas suitable for permanent management as National Forests. Such land might be aequired through gifts, purchases, or exchanges in which the Government returned land or stumpage for the eutover areas acquired. The States might well undertake a similar policy. In aceord with its principle, the States should retain permanently all the lands now owned which are shown by an expert classification to be suitable mainly for forest growth. Lands of like character obtained through nonpayment of taxes or otherwise acpuired should be added to these permanent State forests.

It would also be desirable for the public to acquire lands interspersed through the holdings of private owners upon which there is a growth of young timber which will not become merchantable for some years. Furthermore, there is a considerable quantity of privately owned timberland, located principally within the existing National Forests, so remote from means of transportation that the timber has no value for immediate conversion into lumber. Where owners of sueh timber are inelined to turn it over to the public at a low price, means should be provided whereby they may do so.

Such a policy should not be developed as a means of giving hard-pressed timber owners an opportunity to liquidate at a profit. Prices should be held down to the value of the tracts for public forest purposes. Similar provisions are now in effect under the Weeks Act, for taking into public ownership land whose control is essential for watershed protection purposes.

The great load of privately owned timber, with all its evils, is at the root of the difficulties of the lumber industry and of the publie losses which the present situation involves. The Government itself, through its ill adjusted land laws, is partly responsible for the situation which has arisen; but the justification for the recovery of a portion of these lands lies in the vital public interests which can be safeguarded most effectively by this means. In a region like the Inland Empire where the rate of growth is relatively slow and the fire danger is considerable the production of timber on a large seale and the protection of watersheds is usually better adapted to public than private enterprise, since the private individual can afford to do it excepting when there is a rare combination of favorable conditions. A forward looking land policy should be adopted by the Federal and State governments as the surest solution of this great problem.

The most serious objection to this plan is that it would remove land from taxation and thus burden loeal communities. This is a drawback which must be provided for definitely in the public ownership policy. In the case of the National Forests the government is providing compensation in lieu of taxes to local communities by turning over 25 per cent of the gross receipts from the sale of timber and other resources. An additional 10 per cent is spent locally in road construction.

It is not to be inferred that the author of this bulletin is opposed to private ownership of timberland. He believes that the private owner can secure a low rate of interest by engaging in the business of growing timber; and that private owners who are willing to accept a moderate return should be encouraged to remain in the business. The policy outlined above should by all means be put in to effect to protect public interests until private owners are content with the relatively small profits obtainable from permanent forest management. Public initiative in acquiring forest land should be supplemented by cooperation between the Government and private owners with the object on one hand of providing for the protection of forests from fire and other forms of injury, for the maintenance of forest growth on cutover lands, and on the other hand of providing conditions under which private owners may engage in the business of growing timber with reasonable prospects of moderate profits.

GOVERNMENT COOPERATION WITH THE INDUSTRY.

Once more let it be emphasized that the Government should definitely and energetically encourage the lumber industry in doing those things which only the industry itself can do to improve its condition. Developments of this character should be aceompanied by a large degree of public cooperation, both to give the industry what aid is possible and also to protect the public welfare and hold the confidence of the public in what the industry may undertake. Suggestions along these lines are made in the following section.

\section{WHAT THE INDUSTRY CAN DO}

COMPETITION OFTEN EXTREME AND DESTRUCTIVE.

While there are certain ways in which the people as a whole misunderstand the industry and in which the actions of governmental agencies bear upon its prosperity, 
there are also many evils in the situation which can be cured only by action of the industry itself. In a word, the lumber industry needs to be modernized.

Far from there being a lumber trust, the competition in the industry is usually keen and frequently destructive. This competition exists between lumber and substitutes for lumber, between various large producing regions, as the Inland Empire and the Fir region, between different parts of the Inland Empire, as between the northwest Montana region and the Missoula region, between different companies within each region, and even between different mills of the same company. Indeed, there are frequent instances of extreme individualism and lack of coordination between different officers of the same plant, as when the woods foreman sends in exceedingly defective logs in the effort to show a low cost of logging, or the sawyer in the mill saws carelessly in order to show a big output, instead of cooperating with the management in getting the maximum returns from the whole organization. What is needed in the lumber industry is the modern spirit of cooperation rather than the extreme spirit of individualism which now exists.

\section{THE LUMBERMAN TOO INDIVIDUALISTIC.}

Although the lumberman has shown the many admirable traits of the pioneer, going boldly into a wilderness and subduing it by main strength applied through rule of thumb methods devised by his native ingenuity, he has developed, in consequence of his comparative isolation, a decidedly individualistic character. He shows something of the character of the independent and self-sufficient feudal lord; it has been necessary for him to be self-reliant, and he has developed an aloofness and lack of trust in other lumbermen; he trusts and believes in his own methods and distrusts the methods of others. His isolation has made him more or less provincial and kept him out of touch with the cooperative spirit of the times. At a meeting of lumbermen there is frequently an agreement upon a general policy but an immediate falling out over non-essential details.

If the lumber industry is to be modernized through cooperation, each unit, whether it be laborer, woods foreman, shipping department, company, or region, must give more consideration to the good of the whole, and stop following the present policy of "Every man for himself and the devil take the hindmost."

LARGE SCALE UNITS OF PRODUCTION.

It has been suggested that it would be desirable to organize in the Inland Empire one large corporation including within its scope ownership of all of the timberland now privately owned and all the plants now operating. Even if the Federal authorities were to permit such a corporation, which in fact would produce less than 6 per cent of the softwood of the country, it appears exceedingly doubtful if one could be brought into existence. The reason for this is again the individualism characteristic of lumbermen.

It has also been suggested that several large corporations be organized, each with an output of say four or five hundred million feet of lumber annually, - sufficiently large to justify all of the overhead expenses which are needed to make a modern, large-scale business successful. Perhaps one corporation of the size indicated could be organized, but it is very doubtful if others could.

Where it can be employed, large scale production with several mills in one organization has many advantages. These include the financial ability and the volume of output necessary to employ a staff of experts in various lines, the development of a strong selling organization with a large stock from which to draw, the elimination of cross shipments to some extent, the standardization of accounting, and a strong central purchasing department.

\section{COOPERATION THROUGH TRADE ASSOCIATIONS.}

The greatest hope of cooperation lies in bringing the manufacturers together through trade associations for handling features of the industry requiring specialization and rosearch which no one concern can afford. The present activities of the Western Pine Manufacturers' Association, for instance, could be greatly extended. The association could develop a corps of experts in various lines who would be available to the individual lumberman to furnish information, check up his technical practice, and aid him as consulting experts to increase the efficiency of his business.

STANDARDIZATION OF ACCOUNTING NETHODS.

The methods of accounting found in the course of this investigation are far from uniform. When one mill man tells his neighbor that it costs him $\$ 1.25$ per thousand feet to saw lumber it usually does not mean the same thing to each; one is including items that the other is leaving out. Many companies keep their accounts in such 
poor fashion that it is impossible to compare their costs with those of other companies. Not a few housewives keep hetter and more detailed aceounts than some lumber companies. Practically no companies carry their eost acemunting system to the degree of refinement which many modern business organizations consider necessary.

Uniform and adequate cost accounting systems, showing at just what point loss replaces gain, afford an important check upon indiscriminate price cutting. With a proper spirit of cooperation, uniform accounting and cost keeping systems could readily be developed by an association accountant who had access to the records of the various members. Accounting methods conld be standardized and much data secured which conld be brought together, summarized for the whole industry, and made arailable to the members of the association for their guidance.

TRADE MARKING AND ADVEIRTISING.

Tracle marking is a recent development in the lumber inclustry. It seeks to standardize the quality of the product, fix responsibility for shipments upon the producing mill, and correct such abuses as grarle inanipulation, which have worked against lumber as a competitive structural material. It is in line with the most desirable inprovements in merchandising lumber, toward the principle of "guaranteed goods." No one doubts that trade marked goods can be marketed to better advantage than those bearing no trade mark.

The trade mark, furthermore, gives something definite to advertise. Cooperative advertising, including various forms of pulblicity, is one of the most desirable forms of joint action for lumbermen to take. An expert representing the association would here be of great assistance.

TIIE SALES AGENCY.

The marketing of lumber offers opportunities for material improvement. There is room for a reduction in the cost of selling, owing to duplicated efforts on the part of sales managers and salesmen, which not only increase the cost of getting the product to the consumer but also tend to lower the price indiseriminately. A sales agency fully acquainted with the stocks at each mill could distribute orders in such a way as to utilize them to the best advantage, thus making it possible to reduce the average yard stocks and so effect a reduction in the investment. It could also make a saving in freight rates by eliminating cross shipments to some extent, and it could secure more detailed information on market conditions than is now obtained, thus enabling sales to be made more intelligently. A sales ageney might be a division of the association, but probably should be an independent organization.

Marketing might be carried a step further by the agency, to bring the product more directly to the consumer and eliminate intermerliate handling. Besides reducing the cost of the product to the consumer and putting lumber in a better position to compete with substitutes, this would keep the merchandising more closely in the hands of the manufacturer, who is most deeply interested in pushing lumber sales. The Federal Trade Commission, or some similar public organization, should be in close contact with the workings of such agencies, to make sure both that they are organized on a thoroughly stable basis and that the public interests are protected in their operation.

POSSIBILITIES OF SCIENTIFIC MANAGEMENT.

Scientific management has been applied with great success in some industries. Its principles are universally applicable. The association could develop an expert in this line whose business it would be to indicate how these principles may be applied to the practical requirements of the companies making up the association membership and to the specific operations of the industry.

The application of scientific management to the industry would be effective mainly in reducing costs of production and in securing economies in the distribution of lumber. Sicientific management consists essentially in substituting for rule of thumb methods, hased largely on tradition and custom, methods which are the result of hard study of the problem in hand and which are in thorough harmony with all of the laws of nature and human nature having any bearing on the case. There is little question that the application of scientific management by a thoroughly qualified man could bring about worth-while economies in the manufacture and handling of lumber.

INDUSTRIAL RESEARCH.

In connection with the application of scientific management, there should be a research department of the association to give special attention tc the development of the science of logging and manufacturing lumber, so that the most economical methods may be determined and employed in each phase of the industry. The 
- research department would determine, for instance, what character of logs it pays to bring in under given costs of logging and under given market conditions; what products can be manufactured most profitably from different kinds of logs; how these products may best be treated in drying, etc.

The dry kiln practice of the region is decidedly diverse; yet there is certainly some one best method for use under each set of conditions. It is highly probable that the best methods have not yet been developed, since the basic scientific principles of kiln drying have not yet been applied in practice.

Mill and woods wastes need to be inrestigated; in some places there is room for saving; in others perhaps the present utilization is too close to be profitable. Investigation of the possible uses of short lengths, chemical by-products, etc., is a further need of the industry. The development of a commercial value for the large proportion of the raw material now wasted would go far in solving basic problems.

TRAINED MEN TEEDED.

One of the most important fields for the application of scientific management is in the selection of the personnel of the industry, from managers to swampers. At the present time the industry employs men by decidedly haphazard methods. The intelligent selection of men for particular positions has been found to increase greatly the work done by the organization and to promote the general efficiency of the companies in which it has been used.

A serious weakness of the lumber industry is the lack of carefully trained, broad minded young men ready to be called into service in the more responsible positions as openings occur. The most successful industries in the country are very keen in their efforts to develop an effective personnel, and to have promising young men of the right ability available and in training. The industry can be greatly strengthened in the long run by securing energetic young men of technical education, giving each of them a thorough training in the various phases of the business, and fitting such of them as prove competent into vacant positions which they may be qualified to fill.

THE LABOR PROBLEM.

The lumber industry has done its share to develop a condition whereby about $3,000,000$ men in the United States have become casual laborers, sometimes called hobo laborers, or "blanketstiffs." There is no one who complains more bitterly than the lumberman, as a rule, of the character of his labor, and yet is he not largely responsible? When urged to improve living conditions in the camps in order to attract a better class of labor, some managers have said better living conditions would tend to spoil the lumberjack. The lumber company manager does not expect to drive logs up the river; they must go down the river. Such are the laws of nature. But he frequently does expect and try to house and keep his labor in violation of the laws of human nature, and can not underst and his resulting difficulties.

The condition of many logging camps indicates that sanitation and comfort have so far received scant attention. It has been clearly demonstrated in several industries, and to some extent in the lumber industry, that it pays to provide camps that are thoroughly sanitary. with good facilities for bathing and for drying wet clothes, with well lighted reading rooms, with simple amusements, with opportunities for schooling, etc. Modern hygiene has demonstrated that men who have slept in improperly ventilated bunk houses reach their highest efficiency only after several hours work in the open air in the morning. Some camps have excellent conditions; in the worst camps life is endurable for the average man only with the prospect of an early debauch.

When labor is scarce and in strong demand, it is extremely restless and migrates very freely, much to the lumberman's disgust. When work is scarce, it is possible to get more efficient labor, and men will stick to their jobs better. This unstable labor situation means inefficiency in the highest degree. Yet what adequate steps are being taken to cure the situation?

The labor situation is one of the most serious reaknesses of the industry; and it is likely to become more serious. The solution of this difficulty lies in the development of stable labor in place of the present migratory labor, of moderately satisfied labor in place of the present dissatisfied labor. This involves reducing to the minimum the seasonal character of operations, providing work for the off seasons, encouraging family life and the settlement of employees on agricultural lands, improving housing conditions, etc. 'The initiative to secure these better conditions must be taken by the employer. Action in these directions should be taken, not merely to appease labor, but because it is the right and fair thing to do. Employers in the aggregate can not dodge their share of responsibility for present conditions. nor should they avoid initiating action to improve matters. Employers can not 
enter into the spirit of scientific management without developing a real, not a simulated, interest in the welf are of the men. Real cooperation must be developed between the employer and the laborer.

Of course there is a great cleal to be said on the employers' side of this question. However, the employer should take the initiative in studying and dealing with the labor problem, the final solution of which will eertainly require hearty cooperation between employer and employed.

\section{PERMANENT FOREST MANAGEMENT.}

The profits to be expeeted from the permanent management of forest lands for the production of timber erops are not suffieiently great to be attractive to many lumbermen. However, individuals are likely to become more conservative in their ideas as to what constitutes a reasonable profit. Furthermore, it is believed that various steps will be taken by the government to make conditions more favorable for private owners to engage permanently in timber production. With such changes in attitude and conditions considerable areas of private land are likely to be devoted permanently to forest management.

\section{CONCLUSION.}

The lumber industry has many difficulties. It is un-Ameriean to believe that they can not be solved. Their solution, however, will require much hard thinking and friendly cooperation, not only within the industry but on the part of the Government and people who are deeply concerned in its stability. 
APPENDIX 
TABLE 12.-Standing limber in the Inland Empire, publicly and privately owned, by regions and species.

[listimater] stand in millions of feet bourel measure, log seale.]

\begin{tabular}{|c|c|c|c|c|c|c|c|c|c|c|c|}
\hline & ๕ั & 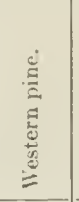 & 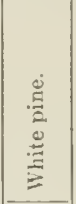 & 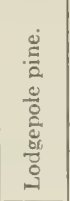 & 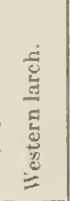 & 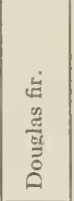 & 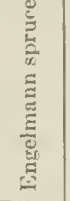 & 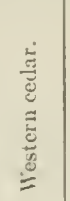 & 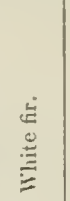 & 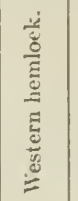 & 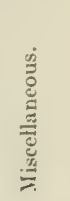 \\
\hline $\begin{array}{l}\text { Montana: } \\
\text { Nort liwest } \\
\text { P'ublic. } \\
\text { P'rivate }\end{array}$ & $\begin{array}{r}17,559 \\
7,598\end{array}$ & $\begin{array}{l}1,200 \\
2,258\end{array}$ & $\begin{array}{r}482 \\
10\end{array}$ & $\begin{array}{l}3,475 \\
\ldots \ldots \\
\end{array}$ & $\begin{array}{l}5,25 \pi \\
3,310\end{array}$ & $\begin{array}{l}3,399 \\
1,652\end{array}$ & $\begin{array}{r}2,4100 \\
368\end{array}$ & 116 & $\begin{array}{r}598 \\
\ldots . .\end{array}$ & $\ldots \ldots$ & $\begin{array}{l}542 \\
\ldots .\end{array}$ \\
\hline Total & $25,15 \pi$ & $3,45 c$ & 492 & 3,475 & 8,567 & 5,051 & 2,858 & 116 & 598 & & 542 \\
\hline $\begin{array}{l}\text { Missoula- } \\
\text { Publie... } \\
\text { Private. }\end{array}$ & $\begin{array}{r}15,647 \\
7,159 \\
\end{array}$ & $\begin{array}{l}3,779 \\
2,738\end{array}$ & $\begin{array}{l}607 \\
176 \\
\end{array}$ & $\begin{array}{r}5,21 \cdot 1 \\
32 \\
\end{array}$ & $\begin{array}{l}1,867 \\
1,927\end{array}$ & $\begin{array}{l}3,408 \\
1,352 \\
\end{array}$ & $\begin{array}{l}304 \\
474 \\
\end{array}$ & $\begin{array}{r}54 \\
159\end{array}$ & $\begin{array}{r}191 \\
3 \\
\end{array}$ & $\begin{array}{l}34 \\
55\end{array}$ & $\begin{array}{r}159 \\
243 \\
\end{array}$ \\
\hline Total & 22,806 & 6,517 & 783 & 5,276 & 3,794 & 4,760 & 778 & 213 & 194 & 89 & 402 \\
\hline $\begin{array}{l}\text { Total Montana- } \\
\text { Public .......... } \\
\text { Private...... }\end{array}$ & $\begin{array}{l}33,206 \\
14,757\end{array}$ & $\begin{array}{l}4,979 \\
4,996\end{array}$ & $\begin{array}{r}1,089 \\
186 .\end{array}$ & $\begin{array}{r}8,719 \\
32 \\
\end{array}$ & $\begin{array}{l}7,124 \\
5,237\end{array}$ & $\begin{array}{l}6,807 \\
3,004 \\
\end{array}$ & $\begin{array}{r}2,794 \\
842\end{array}$ & $\begin{array}{l}170 \\
158\end{array}$ & $\begin{array}{r}789 \\
3\end{array}$ & $\begin{array}{l}34 \\
55\end{array}$ & $\begin{array}{l}701 \\
243\end{array}$ \\
\hline Grand total.... & 47,963 & 9,975 & 1,275 & $\mathrm{~S}, 751$ & 12,361 & 9,811 & 3,636 & 329 & 792 & 89 & 944 \\
\hline $\begin{array}{l}\text { Iclaho and Wyoming: } \\
\text { Pend Oreille- } \\
\text { Public......... } \\
\text { Private....... }\end{array}$ & $\begin{array}{l}5,650 \\
5,072 \\
\end{array}$ & $\begin{array}{r}160 \\
1,413 \\
\end{array}$ & $\begin{array}{l}1,736 \\
1,258\end{array}$ & $\begin{array}{r}67 \\
2 \\
\end{array}$ & $\begin{array}{l}991 \\
638 \\
\end{array}$ & $\begin{array}{l}686 \\
594 \\
\end{array}$ & $\begin{array}{l}397 \\
114\end{array}$ & $\begin{array}{r}1,043 \\
624\end{array}$ & 87 & $\begin{array}{l}161 \\
306 \\
\end{array}$ & $\begin{array}{l}322 \\
123 \\
\end{array}$ \\
\hline Total. & 10,722 & 1,573 & 2,994 & 69 & 1,629 & 1,280 & 511 & 1,667 & 87 & 467 & 445 \\
\hline $\begin{array}{l}\text { Cocur d'Alene } \\
\text { Public. } \quad \ldots \ldots . \\
\text { Private. }\end{array}$ & $\begin{array}{l}5,994 \\
9,375 \\
\end{array}$ & $\begin{array}{r}82 \\
1,084 \\
\end{array}$ & $\begin{array}{l}1,993 \\
3,823 \\
\end{array}$ & $\begin{array}{r}233 \\
3 \\
\end{array}$ & $\begin{array}{r}733 \\
1,350 \\
\end{array}$ & $\begin{array}{l}1,033 \\
1,080\end{array}$ & $\begin{array}{l}485 \\
106\end{array}$ & $\begin{array}{l}159 \\
765\end{array}$ & $\begin{array}{l}780 \\
643\end{array}$ & $\begin{array}{r}386 \\
53\end{array}$ & $\begin{array}{l}110 \\
438\end{array}$ \\
\hline Total. & 15,369 & 1,166 & 5,816 & 236 & 2,113 & 2,113 & 591 & 924 & 1,423 & 439 & 54 \\
\hline $\begin{array}{l}\text { Clearwater- } \\
\text { Public. } \\
\text { Private. }\end{array}$ & $\begin{array}{l}20,793 \\
13,388 \\
\end{array}$ & $\begin{array}{l}2,477 \\
2,269 \\
\end{array}$ & $\begin{array}{l}3,249 \\
7,246 \\
\end{array}$ & $\begin{array}{r}2,311 \\
34\end{array}$ & $\begin{array}{r}1,773 \\
961\end{array}$ & $\begin{array}{l}3,929 \\
1,030\end{array}$ & $\begin{array}{r}1,557 \\
18\end{array}$ & $\begin{array}{r}1,454 \\
769\end{array}$ & $\begin{array}{r}2,891 \\
919\end{array}$ & $\begin{array}{r}170 \\
1\end{array}$ & $\begin{array}{l}9 \mathrm{~S} 2 \\
141\end{array}$ \\
\hline Total. .. & 34,181 & 4,746 & 10,495 & 2,345 & 2,734 & 4,959 & 1,575 & 2,223 & 3,810 & 171 & 1,123 \\
\hline $\begin{array}{l}\text { Southern Idaho and western } \\
\text { Wyoming- } \\
\text { Public. } \\
\text { Private. }\end{array}$ & $\begin{array}{r}35,510 \\
2,340 \\
\end{array}$ & $\begin{array}{l}7,424 \\
1,883 \\
\end{array}$ & & $\begin{array}{r}9,025 \\
35 \\
\end{array}$ & 36 & $\begin{array}{r}12,144 \\
285 \\
\end{array}$ & $\begin{array}{l}2,322 \\
\cdots \cdots \\
\end{array}$ & & $9 \mathrm{~S}$ & $\therefore$ & $\begin{array}{r}4,595 \\
\cdots \cdots \\
\end{array}$ \\
\hline Total. ....... & 37,550 & 9,307 & 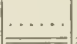 & 9,063 & 36 & 12,429 & 2,322 & $\cdots$ & $9 \mathrm{~S}$ & $\ldots \ldots$ & 4,595 \\
\hline 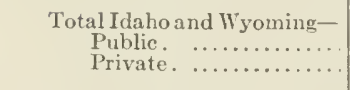 & $\begin{array}{l}67,947 \\
30,175 \\
\end{array}$ & $\begin{array}{r}10,143 \\
6,649 \\
\end{array}$ & $\begin{array}{r}6,978 \\
12,327 \\
\end{array}$ & $\begin{array}{r}11,636 \\
77 \\
\end{array}$ & $\begin{array}{l}3,197 \\
3,015 \\
\end{array}$ & $\begin{array}{r}17,792 \\
2,959 \\
\end{array}$ & $\begin{array}{r}4,764 \\
235 \\
\end{array}$ & $\begin{array}{l}2,656 \\
2,158\end{array}$ & $\begin{array}{l}3,758 \\
1,660\end{array}$ & $\begin{array}{l}717 \\
360 \\
\end{array}$ & $\begin{array}{r}6,009 \\
702 \\
\end{array}$ \\
\hline Grand total . & $9 \$, 122$ & 16,792 & 19,305 & 11,713 &, 512 & 20,781 & 4,999 & 4,814 & 5,418 & $1,07 i$ & 6,711 \\
\hline $\begin{array}{l}\text { ashington: } \\
\text { Northern Washington } \\
\text { (Spokane)- } \\
\text { Public. ........... } \\
\text { Private. ......... }\end{array}$ & $\begin{array}{l}8,280 \\
4,507\end{array}$ & $\begin{array}{l}3,060 \\
2,124\end{array}$ & $\begin{array}{l}260 \\
458\end{array}$ & 299 & $\begin{array}{r}1,719 \\
808 \\
\end{array}$ & $\begin{array}{r}2,350 \\
683 \\
\end{array}$ & $\begin{array}{r}122 \\
19 \\
\end{array}$ & $\begin{array}{l}286 \\
245 \\
\end{array}$ & 168 & $\begin{array}{l}10 \\
59 \\
\end{array}$ & 10 \\
\hline Total. .. & 12,787 & 5,190 & $71 \mathrm{~s}$ & 306 & 2,527 & 3,033 & 141 & 531 & $16 \mathrm{~s}$ & 69 & 1 \\
\hline $\begin{array}{c}\text { Central Washing } \\
\text { Public. } \quad \ldots \\
\text { Private. }\end{array}$ & $\begin{array}{r}16,781 \\
9,488 \\
\end{array}$ & $\begin{array}{l}5,456 \\
5,694 \\
\end{array}$ & $\begin{array}{r}128 \\
15 \\
\end{array}$ & $\begin{array}{r}1,131 \\
25 \\
\end{array}$ & $\begin{array}{l}55 \overline{7} \\
265 \\
\end{array}$ & $\begin{array}{l}5,620 \\
2,803 \\
\end{array}$ & $\begin{array}{l}733 \\
353\end{array}$ & $\begin{array}{r}455 \\
88 \\
\end{array}$ & $\begin{array}{r}325 \\
61 \\
\end{array}$ & $\begin{array}{r}897 \\
90 \\
\end{array}$ & $\begin{array}{r}1,479 \\
94\end{array}$ \\
\hline Total. ..... & 26,269 & 0 & 143 & 156 & 822 & 3 & 086 & 543 & 356 & 987 & 1,573 \\
\hline $\begin{array}{l}\text { Included with Oregon- } \\
\text { Private. . . . . . . . }\end{array}$ & 723 & 252 & & $8 \pi$ & 109 & 152 & 21 & & & & 1 \\
\hline $\begin{array}{l}\text { Total Washington- } \\
\text { Public. } \quad \ldots \ldots \ldots \ldots \\
\text { Private. }\end{array}$ & $\begin{array}{l}25,061 \\
14,718\end{array}$ & $\begin{array}{l}8,522 \\
8,071\end{array}$ & $\begin{array}{l}388 \\
473\end{array}$ & $\begin{array}{r}1,430 \\
119\end{array}$ & $\begin{array}{l}2,276 \\
1,182\end{array}$ & $\begin{array}{l}7,970 \\
3,638\end{array}$ & $\begin{array}{l}855 \\
393\end{array}$ & $\begin{array}{l}7+1 \\
333\end{array}$ & $\begin{array}{r}493 \\
61\end{array}$ & $\begin{array}{l}90 \overline{7} \\
149\end{array}$ & $\begin{array}{r}1,+79 \\
299\end{array}$ \\
\hline Grand total & 39,779 & 16,593 & 861 & 1,549 & $3,45 \mathrm{~s}$ & 11,608 & 1,248 & 074 & 554 & 1,056 & 1,778 \\
\hline
\end{tabular}


TABLE 12.-Standing timber in the Inland Empire, publicly and privately owned, by regions and species-Continued.

[Estimated stand in millions of feet board measure, log scale.]

\begin{tabular}{|c|c|c|c|c|c|c|c|c|c|c|c|}
\hline & 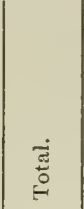 & 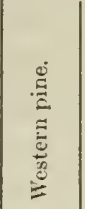 & $\frac{\dot{d}}{\stackrel{\Xi}{2}}$ & 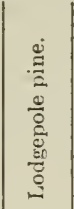 & 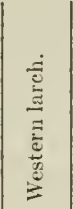 & $\frac{\dot{E}}{\frac{0}{5}}$ & 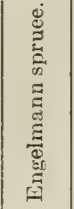 & 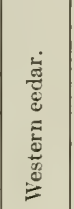 & $\stackrel{5}{\rightleftarrows}$ & 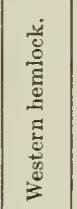 & 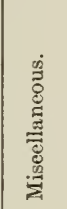 \\
\hline $\begin{array}{l}\text { Oregon: } \\
\text { Eastern Oregon- } \\
\begin{array}{l}\text { Public. } \quad \ldots \ldots \ldots \ldots \ldots \ldots \\
\text { Private. } \quad \ldots \ldots \ldots \ldots \ldots\end{array}\end{array}$ & $\begin{array}{l}20,350 \\
11,025\end{array}$ & $\begin{array}{r}10,437 \\
9,525\end{array}$ & $\begin{array}{r}12 \\
\ldots \ldots\end{array}$ & $\begin{array}{r}1,433 \\
205\end{array}$ & $\begin{array}{r}2,420 \\
505\end{array}$ & $\begin{array}{r}3,200 \\
560\end{array}$ & $\begin{array}{r}3+4 \\
22\end{array}$ & is & $\begin{array}{r}4 \\
\ldots . .\end{array}$ & $\begin{array}{l}\ldots \ldots \\
\ldots \ldots\end{array}$ & $\begin{array}{r}2,500 \\
193\end{array}$ \\
\hline Total . .... & 31,375 & 19,962 & 12 & 1,638 & 2,925 & 3,760 & 366 & 15 & 4 & $\cdots \cdots$ & 2,693 \\
\hline $\begin{array}{l}\text { Deschutes Region- } \\
\text { Public. } \quad \ldots \ldots \ldots \ldots \ldots \ldots \ldots \\
\text { Private. } \quad . \ldots \ldots \ldots \ldots \ldots\end{array}$ & $\begin{array}{r}17,803 \\
7,554 \\
\end{array}$ & $\begin{array}{r}10,009 \\
7,12 \mathrm{~S} \\
\end{array}$ & $\begin{array}{r}13 \\
\ldots \ldots \\
\end{array}$ & $\begin{array}{r}1,136 \\
255 \\
\end{array}$ & $\begin{array}{r}933 \\
18\end{array}$ & $\begin{array}{r}4,435 \\
150 \\
\end{array}$ & $\begin{array}{r}17 \\
\cdots \cdots \\
\end{array}$ & $\left|\begin{array}{l}\cdots \cdots \\
\cdots \cdots\end{array}\right|$ & $\begin{array}{r}13 \\
3\end{array}$ & $\begin{array}{r}31 \\
\ldots . \\
\end{array}$ & $\begin{array}{r}1,216 \\
\ldots \ldots \\
\end{array}$ \\
\hline Total.$\ldots \ldots \ldots$ & 25,357 & 17,137 & 13 & 1,391 & 951 & 4,585 & 17 & $\ldots \ldots$ & 16 & 31 & 1,216 \\
\hline $\begin{array}{l}\text { Klamath Region- } \\
\text { Public. } \quad \ldots \ldots \ldots \ldots \ldots \ldots \ldots \ldots \\
\text { Private. } \ldots \ldots \ldots \ldots \ldots\end{array}$ & $\begin{array}{l}20,432 \\
14,288\end{array}$ & $\begin{array}{l}13,055 \\
10,733 \\
\end{array}$ & $\begin{array}{r}91 \\
\ldots \ldots \\
\ldots\end{array}$ & $\begin{array}{r}3,829 \\
9 \\
\end{array}$ & 176 & $\begin{array}{l}2,125 \\
1,545\end{array}$ & $\begin{array}{r}\quad 55 \\
\ldots \ldots \\
\cdots\end{array}$ & 312 & $\begin{array}{r}1 \\
233 \\
\end{array}$ & $\begin{array}{l}33 \\
2 S \\
\end{array}$ & $\begin{array}{l}1,243 \\
1,252\end{array}$ \\
\hline Total ............ & 34,720 & 23,788 & 91 & $3,83 \varepsilon$ & 176 & 3,670 & 55. & 312 & 234 & 61 & 2,495 \\
\hline 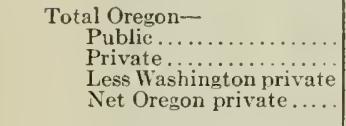 & $\begin{array}{r}58,585 \\
32,867 \\
723 \\
32,144 \\
\end{array}$ & $\begin{array}{r}33,501 \\
27,386 \\
253 \\
27,133 \\
\end{array}$ & $\begin{array}{r}116 \\
\cdots \cdots \\
\cdots \cdots \\
\cdots \cdots \\
\end{array}$ & $\begin{array}{r}6,398 \\
469 \\
87 \\
382 \\
\end{array}$ & $\begin{array}{r}3,353 \\
699 \\
109 \\
590 \\
\end{array}$ & $\begin{array}{r}9,760 \\
2,255 \\
152 \\
2,103 \\
\end{array}$ & $\begin{array}{r}416 \\
22 \\
21 \\
1\end{array}$ & 327 & $\begin{array}{r}18 \\
236 \\
236 \\
\end{array}$ & $\begin{array}{r}64 \\
28 \\
28 \\
\end{array}$ & $\begin{array}{r}4,959 \\
1,415 \\
101 \\
1,344 \\
\end{array}$ \\
\hline Grand total. .......... & 90,729 & 60,634 & 116 & 6,780 & 3,943 & 11,863 & 417 & 327 & 254 & 92 & 6,303 \\
\hline $\begin{array}{l}\text { Total Inland Empire: } \\
\quad \text { Public } \ldots \ldots \ldots \ldots \ldots \ldots \ldots \ldots \ldots \\
\text { Private } \ldots \ldots \ldots \ldots \ldots \ldots \ldots\end{array}$ & $\begin{array}{r}184,799 \\
91,794 \\
\end{array}$ & $\begin{array}{l}57,145 \\
46,840 \\
\end{array}$ & $\begin{array}{r}8,571 \\
12,986 \\
\end{array}$ & $\begin{array}{r}2 S, 183 \\
610 \\
\end{array}$ & $\begin{array}{l}16,250 \\
10,024 \\
\end{array}$ & $\begin{array}{l}42,329 \\
11,734 \\
\end{array}$ & $\begin{array}{l}8,829 \\
1,471 \\
\end{array}$ & $\begin{array}{l}3,567 \\
2,977 \\
\end{array}$ & $\begin{array}{l}5,058 \\
1,960 \\
\end{array}$ & $\begin{array}{r}1,722 \\
592 \\
\end{array}$ & $\begin{array}{r}13,148 \\
2,588 \\
\end{array}$ \\
\hline Grand total.......... & 276,593 & 103,994 & 21,557 & 28,792 & 26,274 & 54,063 & 10,300 & 6,544 & 7,018 & 2,314 & 15,736 \\
\hline
\end{tabular}




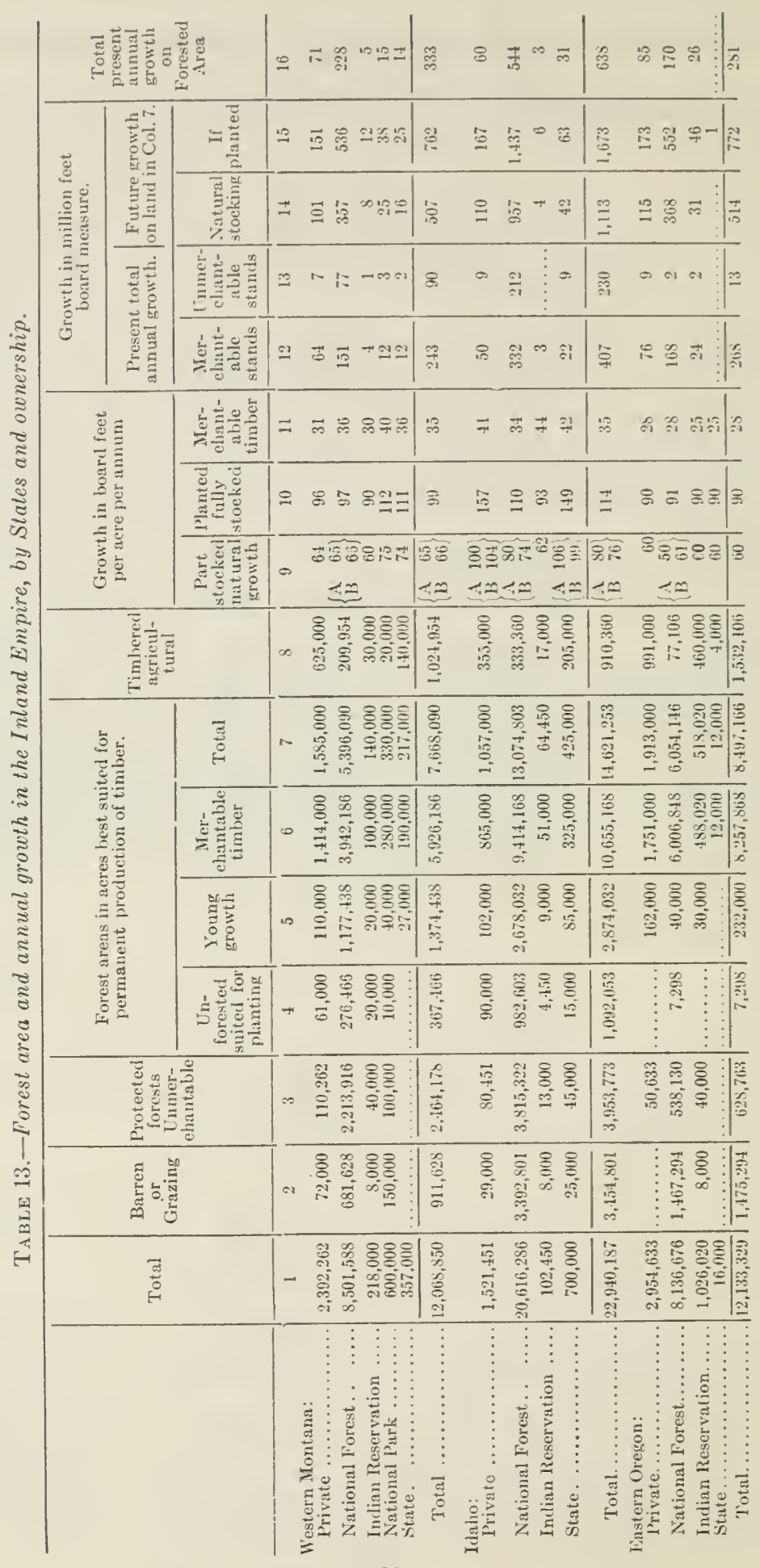




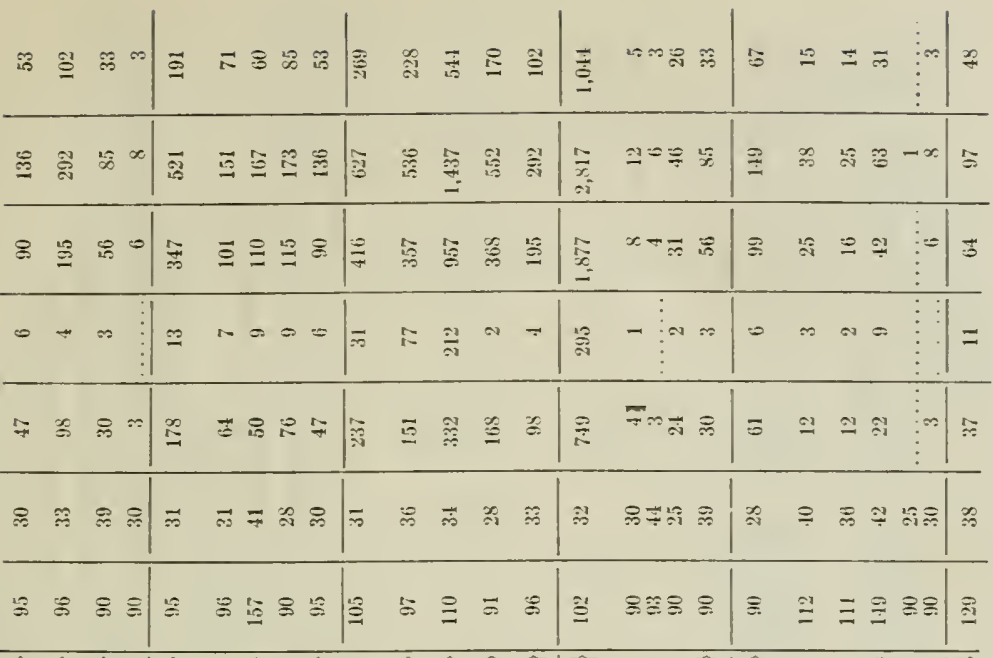

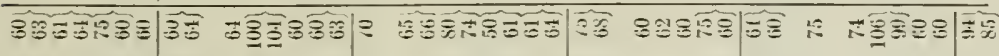

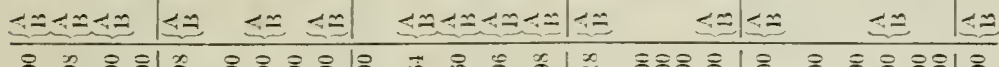

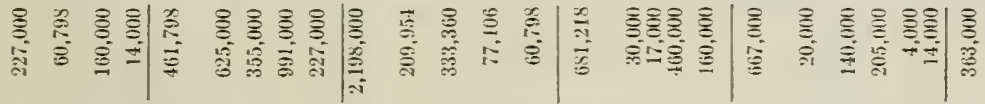
药

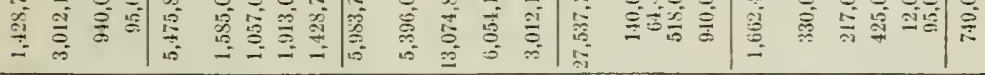
จ

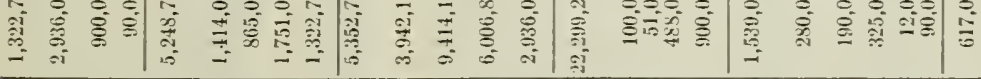

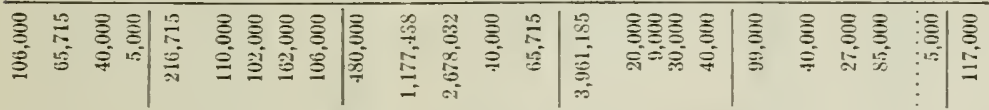
管

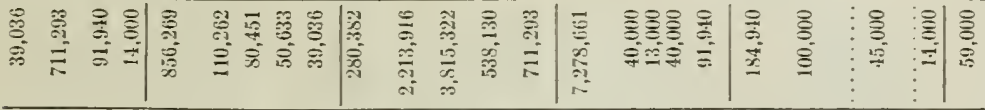

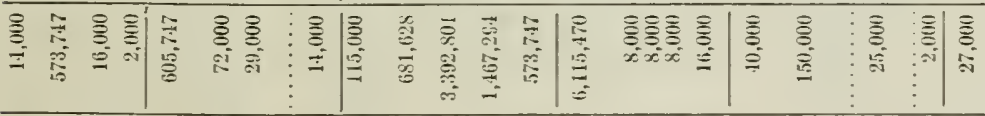

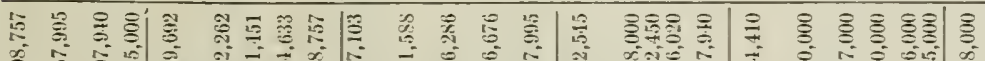

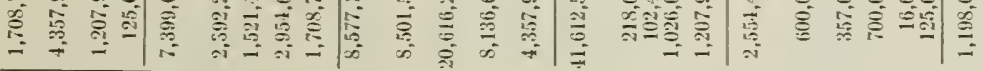

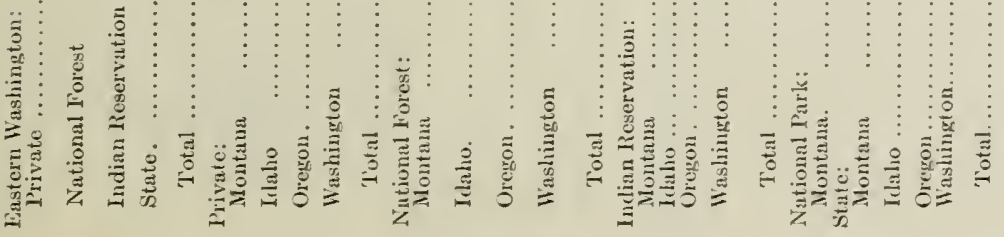




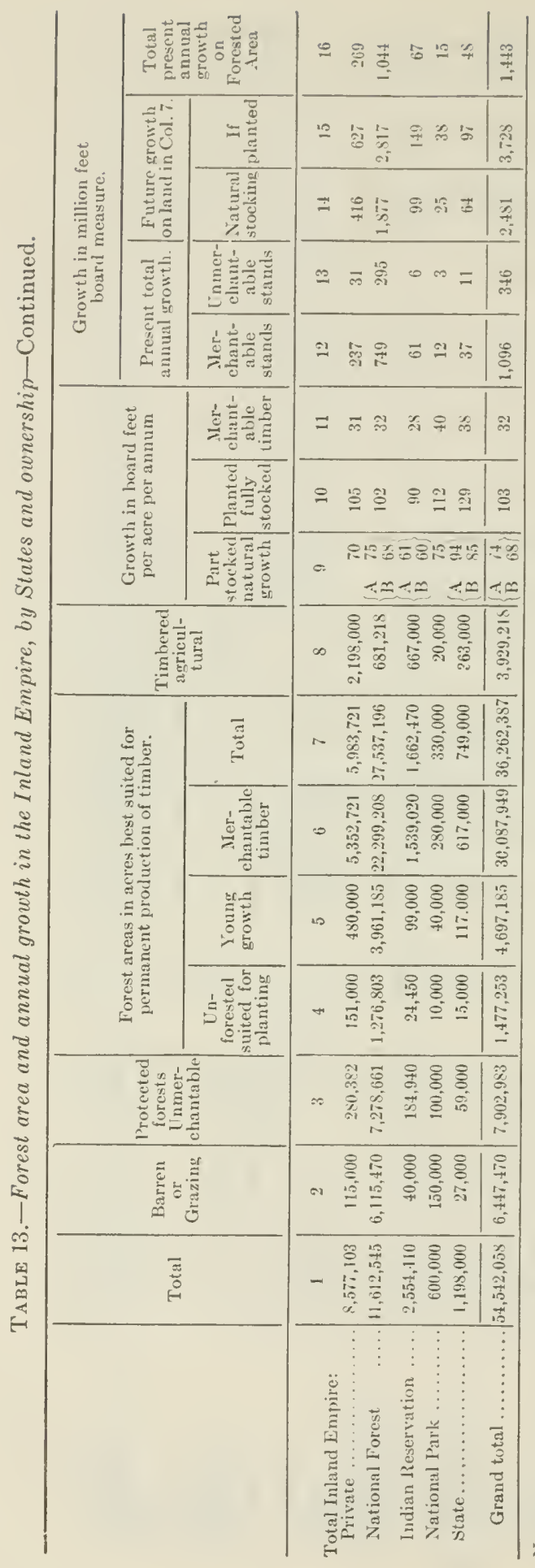

敢

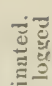

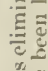

然。

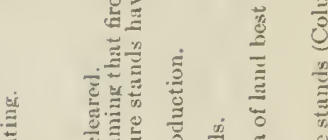

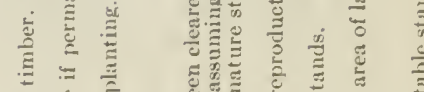

$\geqslant \quad \stackrel{2}{z}$

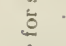

$\frac{a}{3}$

응

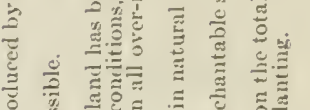

द 5 ¿

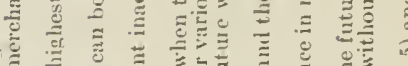

$\exists=2$ c 0

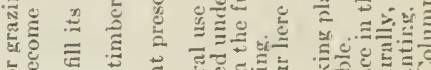

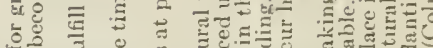

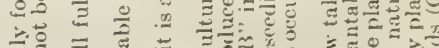

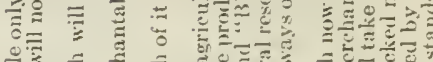

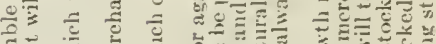

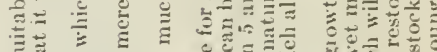

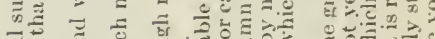

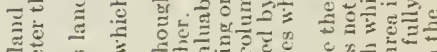

च苞

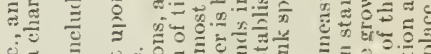

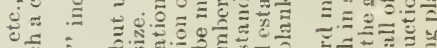

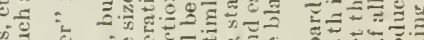

我范

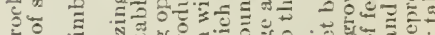

풀

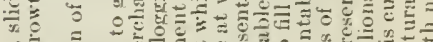

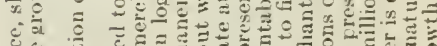

.

论 总

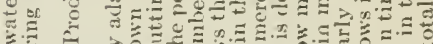

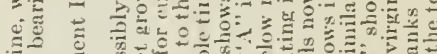

政 0 o

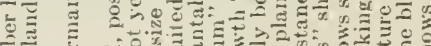

苛苛

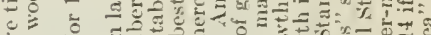

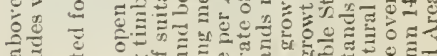

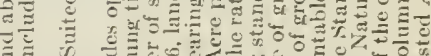

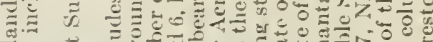

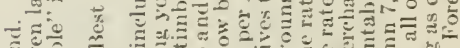

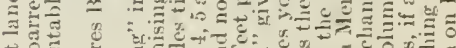

क्ष

๖을

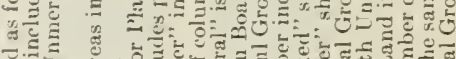

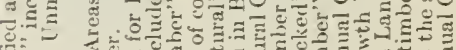

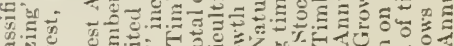

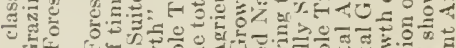

地

년

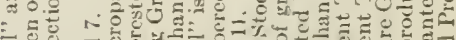

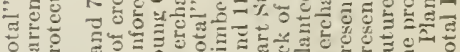
o 는 1 它 


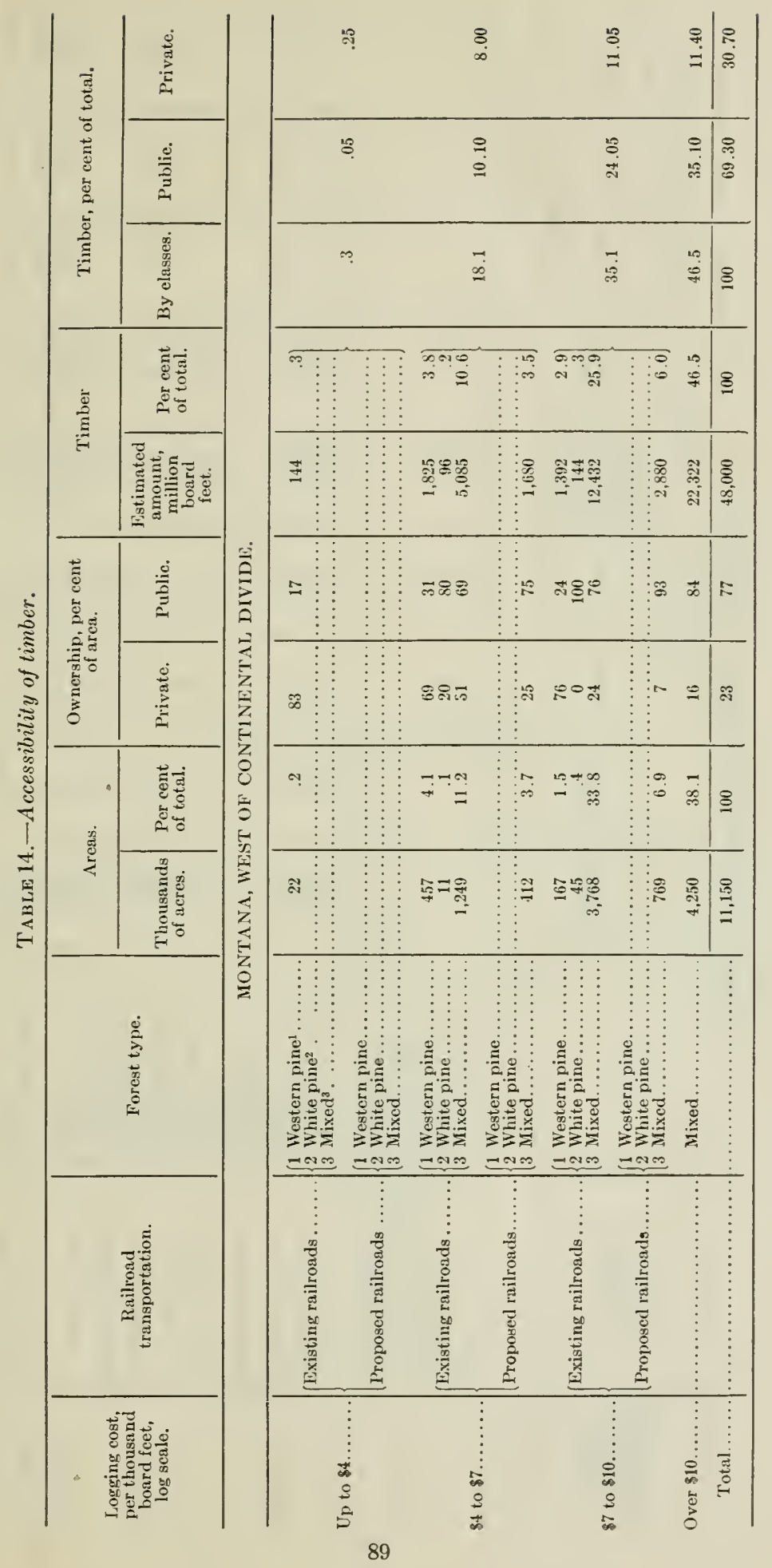




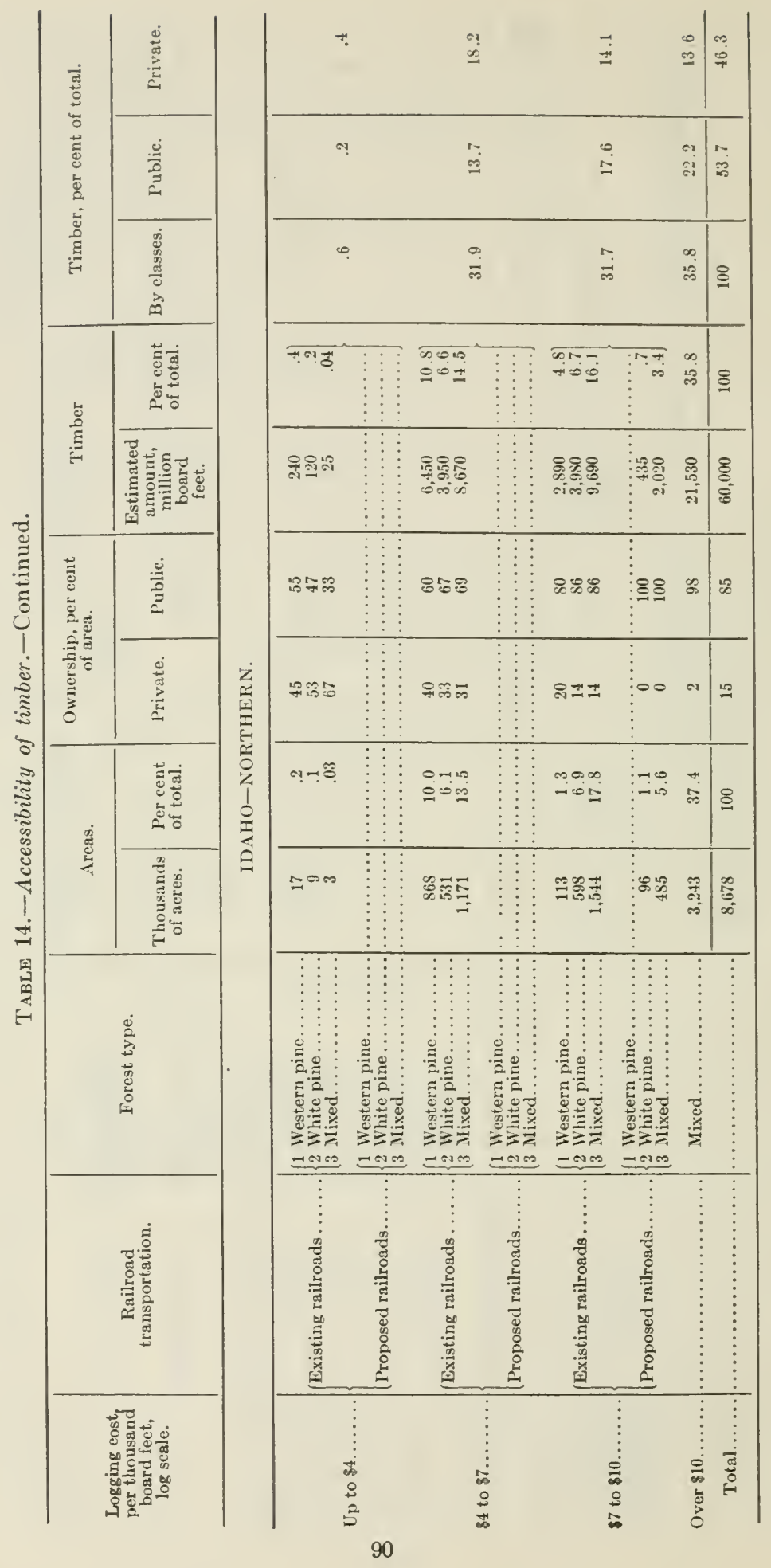




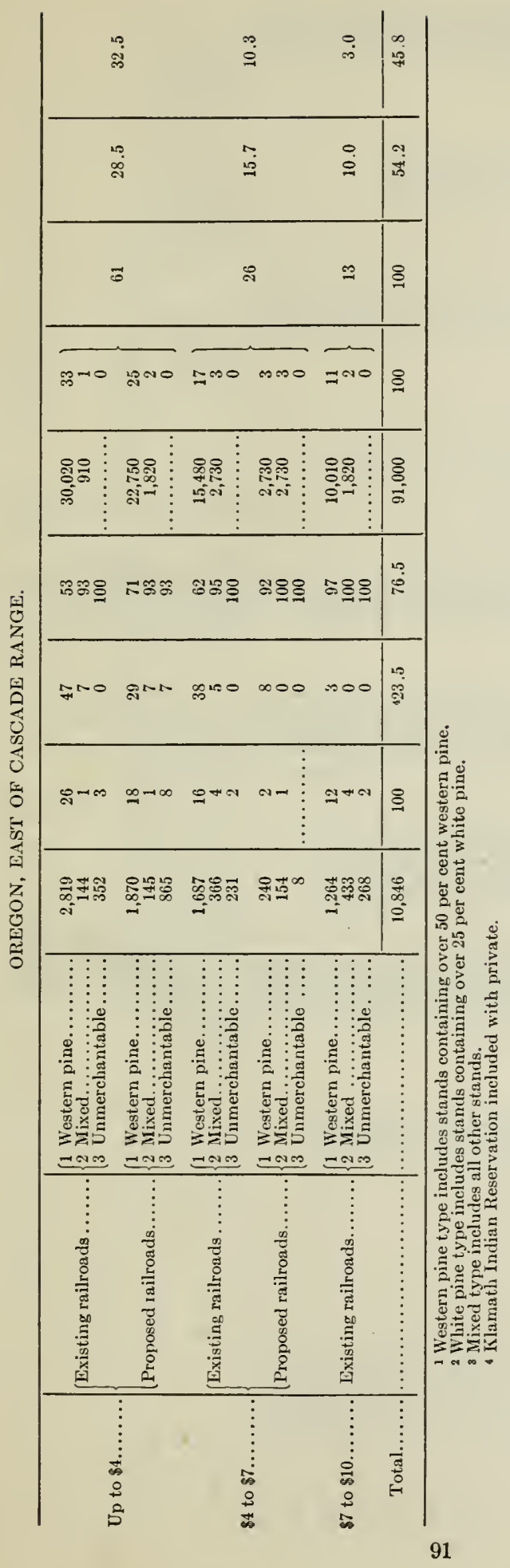


TABLE 15.-Rotation and rate of growth for various forest types under various conditions.

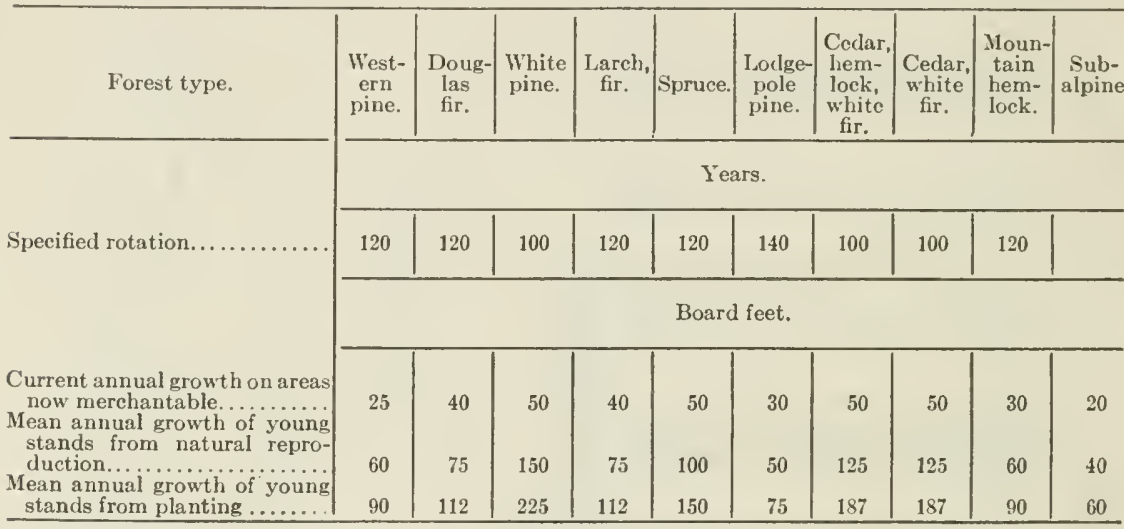

Note. - The rate of growth is estimated for valious forest types on average sites in the Inland Empire. The mean annual growth in board feet is calculated back from the end of the rotation for the present joung growth and for stands grown in future from planting or natural reproduction. No allowance is made for possible thinnings. 


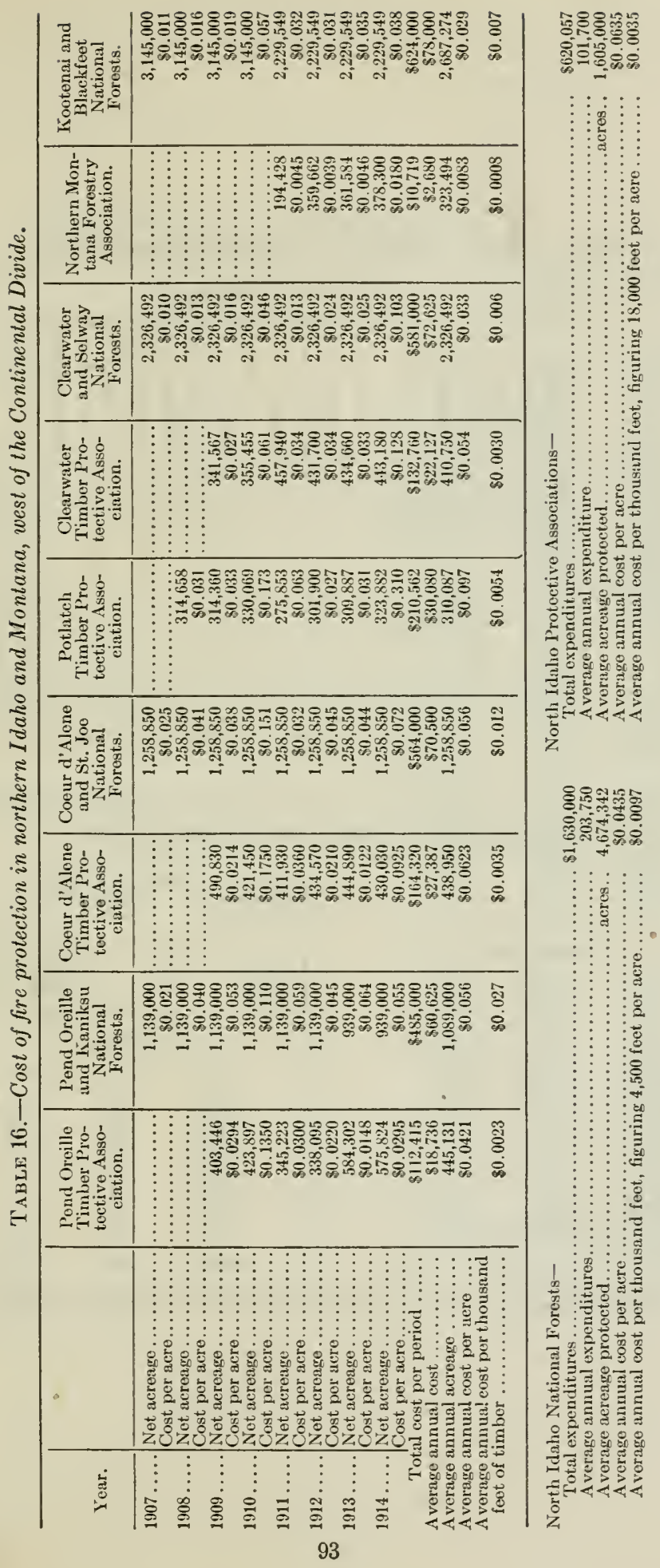


TABLE 17.-Inland Empire cut, by regions and species, 1912.

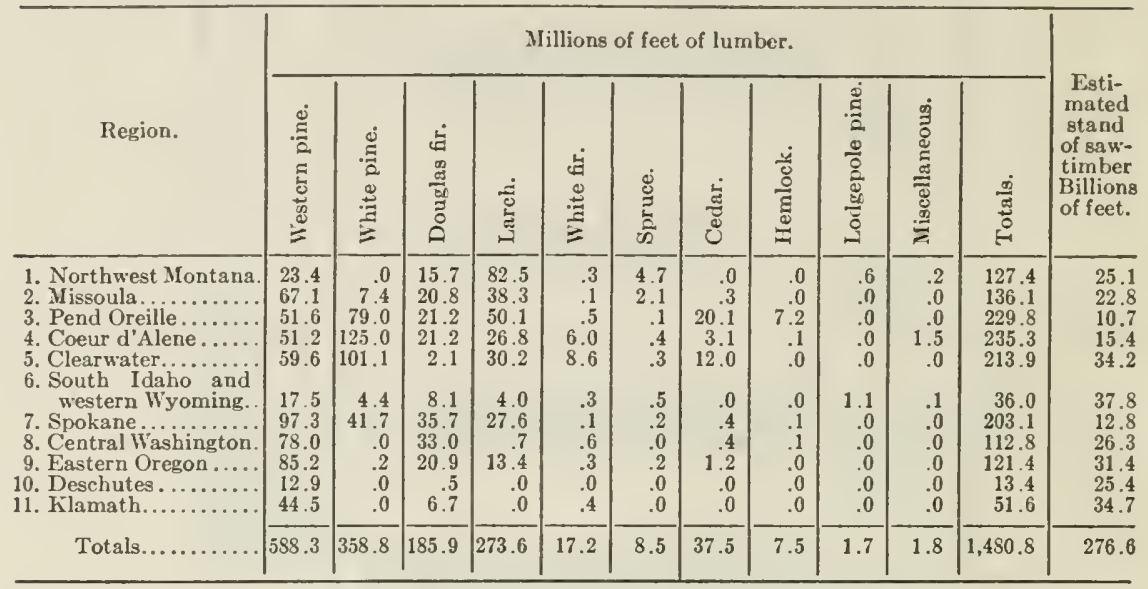

Note.-The rate of cutting in the South Idaho and Deschutes Regions has increased greatly since 1912.

TABLE 18.- Relation of National Forest cut to the total sawtimber cut in the Inland Empire in 1914. Lumber entering general market.

\begin{tabular}{|c|c|c|c|c|}
\hline \multirow{3}{*}{ Producing region. } & \multirow{2}{*}{$\begin{array}{c}\begin{array}{c}\text { Approxi- } \\
\text { mate total } \\
\text { cut. }\end{array} \\
\begin{array}{c}\text { Lumber } \\
\text { tally. }\end{array}\end{array}$} & \multicolumn{2}{|c|}{$\begin{array}{l}\text { National Forest saw- } \\
\text { timber only. }\end{array}$} & \multirow{3}{*}{$\begin{array}{l}\text { Per cent } \\
\text { of total } \\
\text { cut from } \\
\text { National } \\
\text { Forests. }\end{array}$} \\
\hline & & $\begin{array}{l}\text { Log } \\
\text { scale. }\end{array}$ & $\begin{array}{l}\text { Lumber } \\
\text { tally. }\end{array}$ & \\
\hline & \multicolumn{3}{|c|}{ Millions of feet. } & \\
\hline 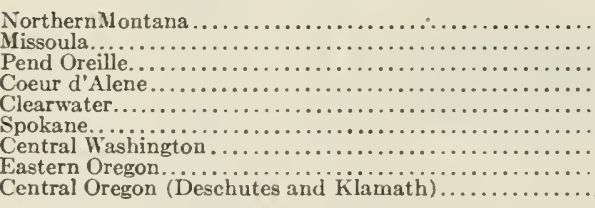 & $\begin{array}{r}150 \\
160 \\
226 \\
288 \\
214 \\
182 \\
90 \\
166 \\
69\end{array}$ & $\begin{array}{r}43 \\
22 \\
27 \\
43 \\
1 \\
1 \\
7 \\
29 \\
24\end{array}$ & $\begin{array}{r}52 \\
26 \\
32 \\
52 \\
\cdots \\
1 \\
9 \\
35 \\
29\end{array}$ & $\begin{array}{r}34.6 \\
16.2 \\
14.1 \\
18.1 \\
.0 \\
.5 \\
10.0 \\
21.4 \\
42.0\end{array}$ \\
\hline Total............. & 1,545 & 196 & 236 & 15.2 \\
\hline
\end{tabular}

Note.-This table does not include eastern Montana, southern Idaho, or Hood River County, Oregon. 
TABLE 19.-Summary of stumpage cost data.

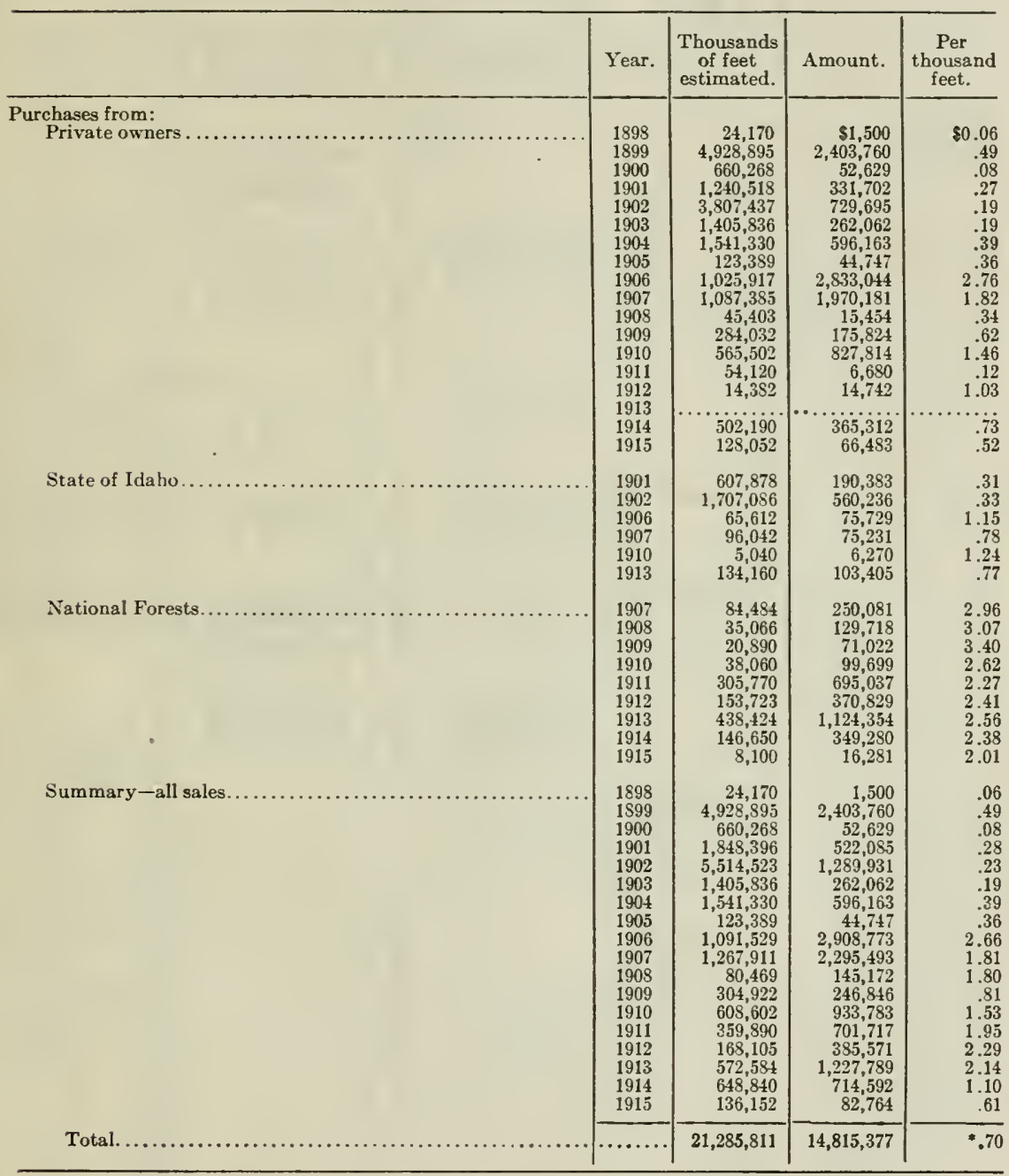

\footnotetext{
Average
} 


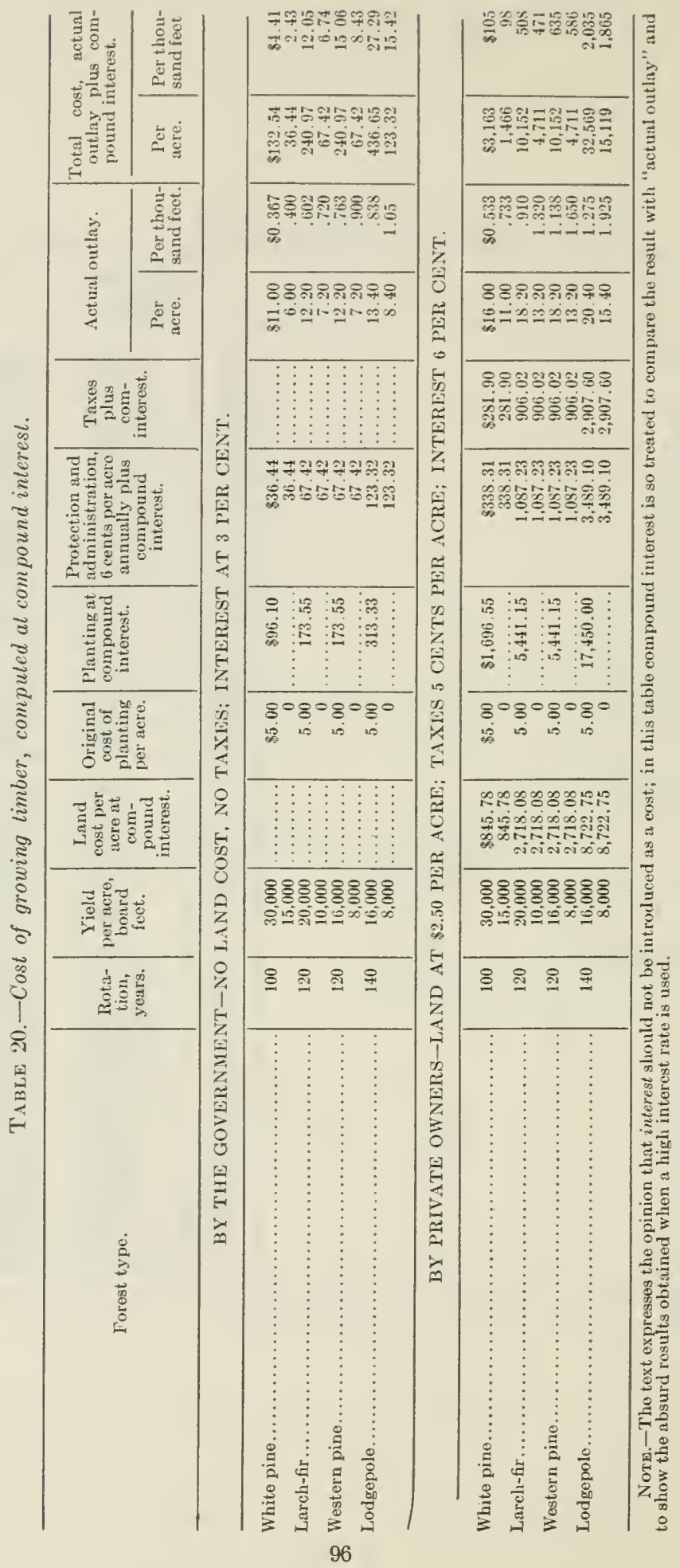


PABLE 21.-Grades of lumber from various species shipped in 1915 by members of the Western Pine Manufacturers' Association.

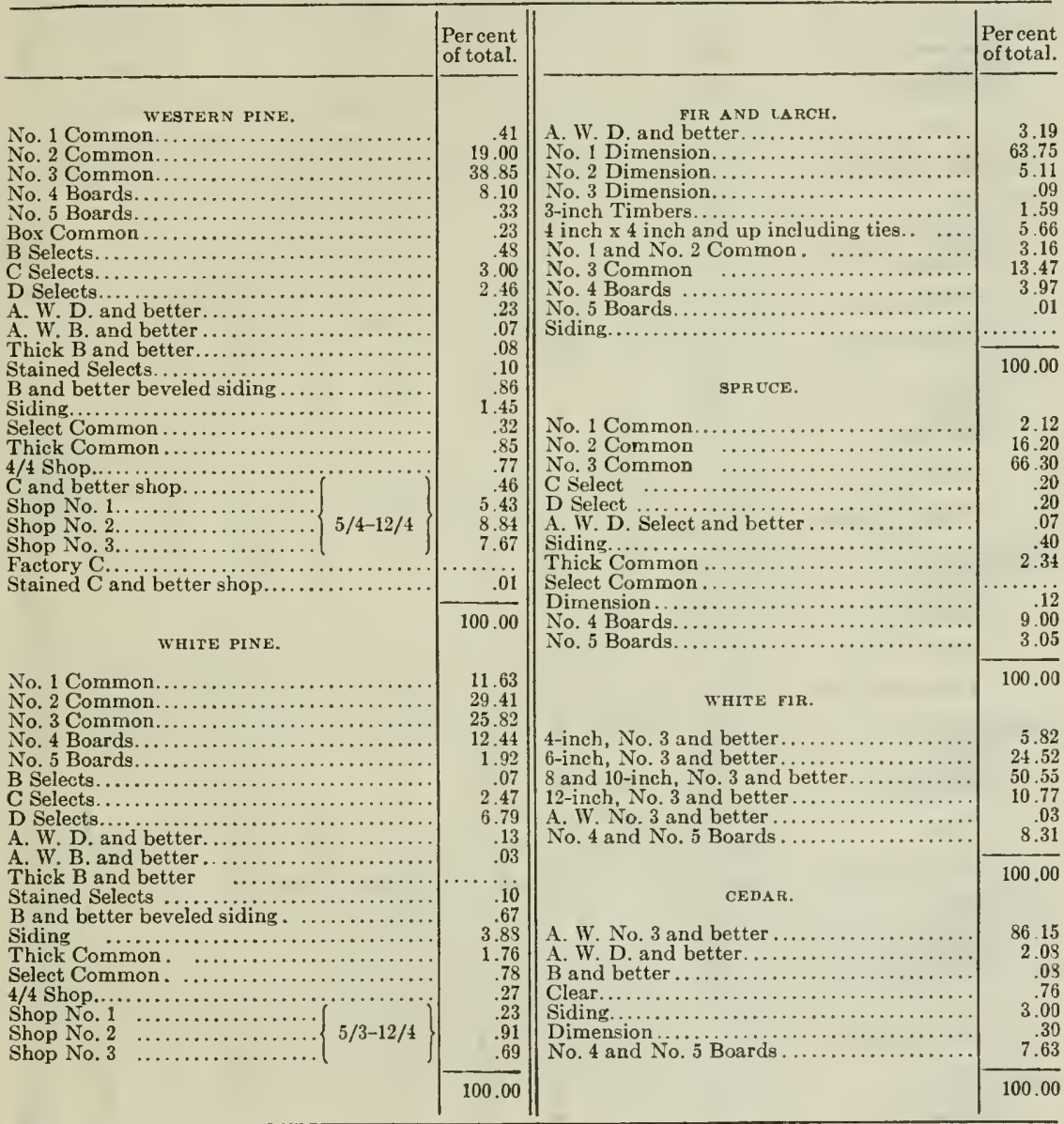


TABLE 22.- Softwood lumber cut in the Inland Empire in various years, by species and States, based on Census and Forest Service data, in millions of feet board measure.

\begin{tabular}{|c|c|c|c|c|c|c|c|c|c|c|c|}
\hline Year. & State. & $\begin{array}{l}\text { West- } \\
\text { ern } \\
\text { pine. }\end{array}$ & $\begin{array}{l}\text { White } \\
\text { pinc. }\end{array}$ & $\begin{array}{l}\text { Doug- } \\
\text { las } \\
\text { fir. }\end{array}$ & Larch. & $\begin{array}{c}\text { White } \\
\text { fir. }\end{array}$ & Spruec. & Cedar. & $\begin{array}{l}\text { ffem- } \\
\text { lock. }\end{array}$ & $\begin{array}{c}\text { Lodge- } \\
\text { pole } \\
\text { pine. }\end{array}$ & Total. \\
\hline \multirow[t]{3}{*}{1900} & 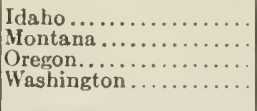 & $\begin{array}{r}53 \\
153 \\
125 \\
94\end{array}$ & $\begin{array}{l}2 \\
4 \\
4\end{array}$ & $\begin{array}{r}5 \\
62 \\
2 \\
10\end{array}$ & $\begin{array}{r}3 \\
34 \\
1 \\
4\end{array}$ & $\ldots \ldots$ & & $\begin{array}{r}2 \\
\cdots \cdots \\
\cdots\end{array}$ & $\because$ & $\begin{array}{l}\cdots \cdots \\
\cdots \cdots \\
\cdots \cdots \\
\cdots\end{array}$ & $\begin{array}{r}65 \\
253 \\
128 \\
113\end{array}$ \\
\hline & Total.... & 425 & 10 & 79 & 42 & $\ldots$ & $\ldots \ldots$ & 3 & . & & 559 \\
\hline & Per cent of total. & 76.1 & 1.8 & 14.1 & 7.5 & $\ldots \ldots \ldots$ & $\because$ & .5 & $\cdots$ & 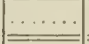 & 100.0 \\
\hline \multirow[t]{3}{*}{1905} & 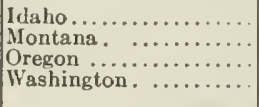 & $\begin{array}{r}84 \\
102 \\
77 \\
215 \\
\end{array}$ & $\begin{array}{l}62 \\
21 \\
33 \\
\end{array}$ & $\begin{array}{r}10 \\
6 \\
9 \\
54 \\
\end{array}$ & $\begin{array}{r}10 \\
39 \\
4 \\
22 \\
\end{array}$ & $\begin{array}{l}\cdots \\
\cdots \\
\cdots\end{array} \ldots$ & \begin{tabular}{|l|}
$\ldots \ldots$ \\
$\cdots \cdots \cdots$ \\
$\cdots \cdots$ \\
$\cdots \cdots$ \\
\end{tabular} & $\begin{array}{r}16 \\
3 \\
1 \\
\end{array}$ & $\begin{array}{r}2 \\
5 \\
\cdots \cdots \\
\cdots \cdots \\
\end{array}$ & & $\begin{array}{r}184 \\
176 \\
90 \\
325\end{array}$ \\
\hline & Total .. & 478 & 116 & 79 & 75 & 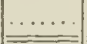 & & 20 & 7 & $\ldots \ldots$ & 775 \\
\hline & Per cent of total. & 616 & 15.0 & 102 & 9.7 & & $\ldots \ldots$ & 2.6 & .9 & $\ldots \ldots$ & 100.0 \\
\hline \multirow[t]{3}{*}{1906} & $\begin{array}{l}\text { Idaho } \ldots \ldots \ldots \ldots \ldots \ldots \\
\text { Montana } \ldots \ldots \ldots \ldots \ldots \ldots \\
\text { Oregonn................. } \\
\text { Washington } \ldots \ldots \ldots \ldots\end{array}$ & $\begin{array}{l}211 \\
167 \\
121 \\
263 \\
\end{array}$ & $\begin{array}{r}84 \\
6 \\
23 \\
\end{array}$ & $\begin{array}{l}35 \\
42 \\
10 \\
72 \\
\end{array}$ & $\begin{array}{r}40 \\
91 \\
4 \\
29 \\
\end{array}$ & $\begin{array}{r}10 \\
14 \\
1 \\
\end{array}$ & $\begin{array}{l}4 \\
4\end{array}$ & $\begin{array}{r}28 \\
\cdots \cdots \\
2 \\
\end{array}$ & $\begin{array}{r} \\
\ldots \\
\cdots \cdots \\
\ldots \ldots\end{array}$ & & $\begin{array}{l}416 \\
324 \\
135 \\
390 \\
\end{array}$ \\
\hline & Total............ & 762 & 113 & 159 & 164 & 25 & 8 & 30 & 4 & $\ldots \ldots$ & 1,265 \\
\hline & Per cent of total. & 60.2 & 8.9 & 12.6 & 13.0 & 2.0 & .6 & 2.4 & .3 & $\ldots \ldots$ & 100.0 \\
\hline \multirow[t]{3}{*}{1907} & $\begin{array}{l}\text { Idaho } \ldots \ldots \ldots \ldots \ldots \ldots \\
\text { Montana } \ldots \ldots \ldots \ldots \ldots \ldots \\
\text { Oregon................. } \\
\text { Washington } \ldots \ldots \ldots \ldots\end{array}$ & $\begin{array}{l}258 \\
165 \\
125 \\
241 \\
\end{array}$ & $\begin{array}{r}80 \\
3 \\
23 \\
\end{array}$ & $\begin{array}{l}73 \\
35 \\
14 \\
92 \\
\end{array}$ & $\begin{array}{r}56 \\
107 \\
7 \\
37 \\
\end{array}$ & $\begin{array}{r}23 \\
26 \\
i \\
\end{array}$ & $\begin{array}{r}2 \\
8 \\
\cdots \cdots \\
\cdots \cdots \\
\end{array}$ & $\begin{array}{r}17 \\
1 \\
1 \\
\end{array}$ & $\begin{array}{r}2 \\
\ldots \ldots \\
\cdots \cdots \\
\cdots \cdots \\
\end{array}$ & & $\begin{array}{l}511 \\
344 \\
147 \\
395\end{array}$ \\
\hline & Total..... & 789 & 106 & 214 & 207 & 50 & 10 & 19 & 2 & $\ldots \ldots$ & 1,397 \\
\hline & Per cent of total. & 56.5 & 7.6 & 15.3 & 14.8 & 3.6 & 7 & 1.4 & .1 & $\ldots \ldots$ & 100.0 \\
\hline \multirow[t]{3}{*}{1908} & 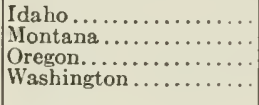 & $\begin{array}{l}209 \\
145 \\
145 \\
191 \\
\end{array}$ & $\begin{array}{r}116 \\
6 \\
25 \\
25 \\
\end{array}$ & $\begin{array}{r}60 \\
39 \\
28 \\
100 \\
\end{array}$ & $\begin{array}{r}76 \\
106 \\
13 \\
41 \\
\end{array}$ & $\begin{array}{r}12 \\
6 \\
1 \\
\end{array}$ & $\begin{array}{r}2 \\
7 \\
\ldots \ldots \\
\cdots \cdots \\
\end{array}$ & $\begin{array}{r}39 \\
2 \\
1 \\
1 \\
\end{array}$ & 1 & $\begin{array}{l}\cdots \cdots \\
\cdots \cdots \cdots \\
\cdots \cdots \cdots \\
\cdots \cdots \\
\end{array}$ & $\begin{array}{l}515 \\
311 \\
187 \\
359 \\
\end{array}$ \\
\hline & Total..... & 690 & 147 & 227 & 236 & 19 & 9 & 43 & 1 & $\ldots \ldots$ & 1,372 \\
\hline & Per cent of total. & 50.3 & 10.7 & 16.5 & 17.2 & 1.4 & .7 & 3.1 & .1 & 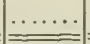 & 100.0 \\
\hline \multirow[t]{3}{*}{1909} & 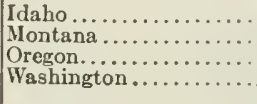 & $\begin{array}{l}254 \\
146 \\
160 \\
263 \\
\end{array}$ & $\begin{array}{r}169 \\
2 \\
3 \ddot{34} \\
\end{array}$ & $\begin{array}{l}64 \\
43 \\
45 \\
90 \\
\end{array}$ & $\begin{array}{r}98 \\
104 \\
22 \\
37 \\
\end{array}$ & $\begin{array}{r}23 \\
3 \\
1 \\
\end{array}$ & $\begin{array}{r}1 \\
7 \\
\cdots \cdots \\
\cdots \cdots \\
\end{array}$ & $\begin{array}{l}29 \\
1 \\
1 \\
\end{array}$ & $\cdots \cdots \cdots$ & $\begin{array}{r}1 \\
3 \\
\cdots\end{array} \mid \begin{array}{r}\mid \\
\cdots\end{array}$ & $\begin{array}{l}640 \\
308 \\
228 \\
426 \\
\end{array}$ \\
\hline & Total.... & 823 & 205 & 242 & 261 & 27 & 8 & 31 & 1 & 4 & 1,602 \\
\hline & Per cent of total... & 51.4 & 12.8 & 15.1 & 16.3 & 1.7 & .5 & 1.9 & 1 & .2 & 100.0 \\
\hline \multirow[t]{3}{*}{1910} & 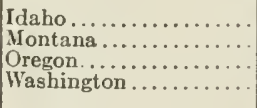 & $\begin{array}{l}281 \\
137 \\
199 \\
253 \\
\end{array}$ & $\begin{array}{r}232 \\
3 \\
13 \\
\end{array}$ & $\begin{array}{l}63 \\
53 \\
52 \\
67 \\
\end{array}$ & $\begin{array}{r}101 \\
99 \\
26 \\
27 \\
\end{array}$ & $\begin{array}{l}25 \\
14 \\
1\end{array}$ & $\begin{array}{r}1 \\
10 \\
\cdots \cdots \\
\cdots \\
\end{array}$ & $\begin{array}{l}39 \\
1 \\
1 \\
1 \\
\end{array}$ & $\begin{array}{l}3 \\
1\end{array}$ & $\begin{array}{r}1 \\
2 \\
\cdots \cdots \\
\cdots \cdots \\
\end{array}$ & $\begin{array}{l}746 \\
319 \\
278 \\
362\end{array}$ \\
\hline & Total. & 870 & 248 & 235 & 253 & 40 & 11 & 41 & 4 & 3 & 1,705 \\
\hline & Per cent of total. & 51.0 & 14.6 & 13.8 & 14.8 & 2.4 & .6 & 2.4 & .2 & .2 & 100.0 \\
\hline \multirow[t]{3}{*}{1911} & 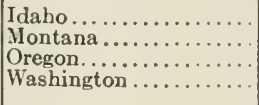 & $\begin{array}{r}221 \\
97 \\
176 \\
183 \\
\end{array}$ & $\begin{array}{r}297 \\
5 \\
20 \\
20\end{array}$ & $\begin{array}{l}77 \\
37 \\
46 \\
74 \\
\end{array}$ & $\begin{array}{l}98 \\
80 \\
23 \\
28 \\
\end{array}$ & $\begin{array}{r}34 \\
3 \\
1 \\
1\end{array}$ & $\begin{array}{r}1 \\
3 \\
\cdots \cdots \\
\cdots \cdots \\
\end{array}$ & $\begin{array}{r}35 \\
1 \\
1 \\
1\end{array}$ & \begin{tabular}{c}
\multicolumn{2}{c}{5} \\
$\cdots \cdots \cdots$ \\
$\cdots \cdots$ \\
$\cdots \cdots$
\end{tabular} & $\begin{array}{r}1 \\
2 \\
\cdots \cdots \\
\cdots \cdots \\
\end{array}$ & $\begin{array}{l}769 \\
227 \\
246 \\
307 \\
\end{array}$ \\
\hline & Total. $\quad \ldots \ldots \ldots$ & 677 & 322 & 234 & 229 & 38 & 4 & 37 & 5 & 3 & 1,549 \\
\hline & Per cent of total.. & 43.7 & 20.8 & 15.1 & 14.8 & 2.4 & .3 & 2.4 & .3 & .2 & 100.0 \\
\hline \multirow[t]{3}{*}{1912} & 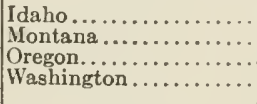 & $\begin{array}{r}180 \\
94 \\
143 \\
175 \\
\end{array}$ & $\begin{array}{r}310 \\
7 \\
792 \\
\end{array}$ & $\begin{array}{l}\mathbf{5 2} \\
39 \\
28 \\
69 \\
\end{array}$ & $\begin{array}{r}111 \\
122 \\
13 \\
28 \\
\end{array}$ & $\begin{array}{r}15 \\
1 \\
1 \\
1\end{array}$ & $\begin{array}{r}1 \\
7 \\
\cdots \cdots \\
\cdots \cdots \\
\end{array}$ & $\begin{array}{c}35 \\
\cdots \\
1 \\
1 \\
\end{array}$ & $\begin{array}{r}\boldsymbol{7} \\
\cdots \cdots \\
\cdots \cdots \\
\cdots \cdots \\
\end{array}$ & $\begin{array}{r}1 \\
2 \\
\cdots \cdots \\
\cdots \cdots \\
\end{array}$ & $\begin{array}{l}712 \\
272 \\
185 \\
316 \\
\end{array}$ \\
\hline & Total...... & 592 & 359 & 188 & 274 & 17 & 8 & 37 & 7 & 3 & 1,485 \\
\hline & Per cent of total...... & 39.8 & 24.2 & 12.7 & 18.5 & 1.1 & .5 & 2.5 & .5 & .2 & 100.0 \\
\hline
\end{tabular}


TABLE 22.-Softwood lumber cut in the Inland Empire in various years, etc.-Continued.

\begin{tabular}{|c|c|c|c|c|c|c|c|c|c|c|c|}
\hline Year. & State. & $\begin{array}{l}\text { West- } \\
\text { ern } \\
\text { pine. }\end{array}$ & $\begin{array}{l}\text { White } \\
\text { pine }\end{array}$ & $\begin{array}{l}\text { Doug- } \\
\text { las } \\
\text { fir. }\end{array}$ & Larch & $\begin{array}{l}\text { White } \\
\text { fir }\end{array}$ & Spruce & Cedar. & $\begin{array}{l}\text { Hem- } \\
\text { lock. }\end{array}$ & $\begin{array}{c}\text { Lodge- } \\
\text { pole } \\
\text { pine. }\end{array}$ & Total. \\
\hline \multirow[t]{3}{*}{1913} & 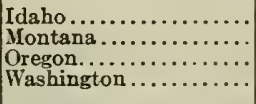 & $\begin{array}{l}179 \\
121 \\
205 \\
190 \\
\end{array}$ & $\begin{array}{r}228 \\
25 \\
2 \% \\
84 \\
\end{array}$ & $\begin{array}{l}67 \\
63 \\
42 \\
92 \\
\end{array}$ & $\begin{array}{r}120 \\
139 \\
21 \\
37\end{array}$ & $\begin{array}{r}28 \\
2 \\
1 \\
1 \\
\end{array}$ & $\begin{array}{l}8 \\
\cdots \\
\cdots\end{array}$ & $\begin{array}{r}23 \\
1 \\
1 \\
1\end{array}$ & $\begin{array}{r}7 \\
\cdots \cdots \cdots \\
\cdots \cdots \cdots \\
\cdots \cdots \\
\end{array}$ & $\begin{array}{r}1 \\
1 \\
\cdots \cdots \\
\cdots \cdots \\
\end{array}$ & $\begin{array}{l}652 \\
358 \\
269 \\
405\end{array}$ \\
\hline & Total. & 695 & 337 & 264 & 317 & 31 & 8 & 25 & 7 & 2 & 1,684 \\
\hline & Per cent of total. & 41.2 & 20.0 & 15.7 & 18.8 & 1.8 & .5 & 1.5 & .4 & .1 & 100.0 \\
\hline \multirow[t]{3}{*}{1914} & 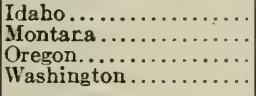 & $\begin{array}{l}160 \\
135 \\
200 \\
173\end{array}$ & $\begin{array}{r}281 \\
18 \\
27\end{array}$ & $\begin{array}{l}96 \\
51 \\
55 \\
50\end{array}$ & $\begin{array}{r}109 \\
102 \\
12 \\
20\end{array}$ & $\begin{array}{l}44 \\
i\end{array}$ & $\begin{array}{c}8 \\
\ldots\end{array}$ & $\begin{array}{r}61 \\
1 \\
1 \\
1\end{array}$ & \begin{tabular}{c}
\multicolumn{1}{c}{12} \\
$\ldots \ldots \ldots$ \\
$\cdots \cdots$
\end{tabular} & $\begin{array}{r}1 \\
2 \\
\ldots \ldots \\
\cdots \cdots \\
\cdots\end{array}$ & $\begin{array}{l}764 \\
317 \\
268 \\
272\end{array}$ \\
\hline & Total. & 668 & 326 & 252 & 243 & 45 & 8 & 64 & 12 & 3 & 1,621 \\
\hline & Per cent of total..... & 41.2 & 20.1 & 15.6 & 15.0 & 2.8 & .5 & 3.9 & .7 & .2 & 100.0 \\
\hline
\end{tabular}

Nоте.-This table includes the cut in eastern Montana but does not include that in western Wyoming.

Table 23.-Cut of identical mills by States-Census data.

\begin{tabular}{|c|c|c|c|c|}
\hline \multirow{2}{*}{ State. } & \multirow{2}{*}{$\begin{array}{l}\text { Number of } \\
\text { mills. }\end{array}$} & Cut in 1915. & Cut in 1914. & \multirow{2}{*}{$\begin{array}{l}\text { Total num- } \\
\text { ber of mills } \\
\text { of same class } \\
\text { reporting in } \\
1914 .\end{array}$} \\
\hline & & \multicolumn{2}{|c|}{ Millions of board feet. } & \\
\hline 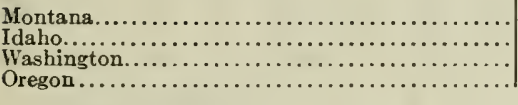 & $\begin{array}{r}7 \\
19 \\
119 \\
49\end{array}$ & $\begin{array}{r}233 \\
519 \\
2,922 \\
1,219 \\
\end{array}$ & $\begin{array}{r}199 \\
573 \\
2,723 \\
1,381 \\
\end{array}$ & $\begin{array}{r}13 \\
25 \\
174 \\
65 \\
\end{array}$ \\
\hline Total......... & & 4,893 & 4,879 & 277 \\
\hline Total for Montana and Idaho........... & ... & 752 & 772 & \\
\hline Decrease.... & & 2.5 per cent & & \\
\hline
\end{tabular}

TABLE 24.-Total lumber cut by States and the number of active mills. From the U.S. Census.

\begin{tabular}{|c|c|c|c|c|c|c|c|c|c|c|c|c|c|}
\hline \multirow{2}{*}{ State. } & \multicolumn{13}{|c|}{ Cut in billions of board feet. } \\
\hline & 1906 & 1907 & 1908 & 1909 & 1910 & 1911 & 1912 & 1913 & 1914 & 1915 & 1916 & 1917 & 1918 \\
\hline 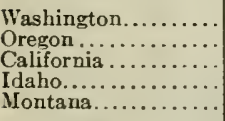 & $\begin{array}{r}4.31 \\
1.60 \\
1.35 \\
.42 \\
.33\end{array}$ & $\begin{array}{r}3.78 \\
1.64 \\
1.35 \\
.51 \\
.34\end{array}$ & $\begin{array}{r}2.92 \\
1.47 \\
1.00 \\
.52 \\
.31\end{array}$ & $\begin{array}{r}3.86 \\
1.90 \\
1.14 \\
.65 \\
.31\end{array}$ & \begin{tabular}{|r|}
4.10 \\
2.09 \\
1.25 \\
.75 \\
.32
\end{tabular} & $\begin{array}{r}4.06 \\
1.80 \\
1.21 \\
.76 \\
.23\end{array}$ & $\begin{array}{r}4.10 \\
1.92 \\
1.20 \\
.71 \\
.27\end{array}$ & $\begin{array}{r}4.59 \\
2.10 \\
1.18 \\
.65 \\
.36\end{array}$ & $\begin{array}{r}3.9 j \\
1.82 \\
1.39 \\
.76 \\
.32\end{array}$ & $\begin{array}{r}3.95 \\
1.69 \\
1.13 \\
.78 \\
.33\end{array}$ & $\begin{array}{r}4.49 \\
2.22 \\
1.42 \\
.85 \\
.38\end{array}$ & $\begin{array}{r}4.57 \\
2.58 \\
1.42 \\
.76 \\
.35\end{array}$ & $\begin{array}{r}4.60 \\
2.71 \\
1.28 \\
.80 \\
.34\end{array}$ \\
\hline \multirow[t]{2}{*}{ Total ......... } & 8.01 & 7.62 & 6.22 & 7.86 & 8.50 & 8.06 & 8.20 & 8.88 & 8.15 & 7.88 & 9.36 & 9.63 & 9.73 \\
\hline & \multicolumn{13}{|c|}{ Number of mills active. } \\
\hline 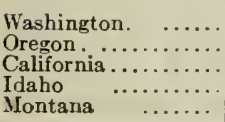 & $\begin{array}{r}923 \\
557 \\
269 \\
198 \\
84\end{array}$ & $\begin{array}{r}1,036 \\
644 \\
321 \\
247 \\
130\end{array}$ & $\begin{array}{l}929 \\
595 \\
288 \\
255 \\
173\end{array}$ & $\begin{array}{r}1,143 \\
696 \\
305 \\
304 \\
180\end{array}$ & $\begin{array}{l}951 \\
574 \\
252 \\
229 \\
140\end{array}$ & $\begin{array}{l}777 \\
522 \\
222 \\
209 \\
126\end{array}$ & $\begin{array}{l}788 \\
480 \\
229 \\
202 \\
118\end{array}$ & $\begin{array}{l}469 \\
406 \\
141 \\
161 \\
109\end{array}$ & $\begin{array}{l}512 \\
409 \\
175 \\
140 \\
124\end{array}$ & $\begin{array}{r}389 \\
363 \\
136 \\
203 \\
94\end{array}$ & $\begin{array}{l}444 \\
525 \\
182 \\
193 \\
103\end{array}$ & $\begin{array}{l}438 \\
409 \\
169 \\
181 \\
122\end{array}$ & $\begin{array}{l}\cdots \cdots \\
\cdots \cdots \\
\cdots \cdots \\
\cdots \cdots \\
\cdots \cdots \\
\cdots\end{array}$ \\
\hline Total ..... & 2,031 & 2,378 & 2,240 & 2,628 & 2,146 & 1,856 & 1,817 & 1,296 & 1,353 & 1,185 & 1,444 & 1,319 & \\
\hline
\end{tabular}


TABLE 25.-Cut and yard stock at mills of various classes in 1914-Millions of feet.

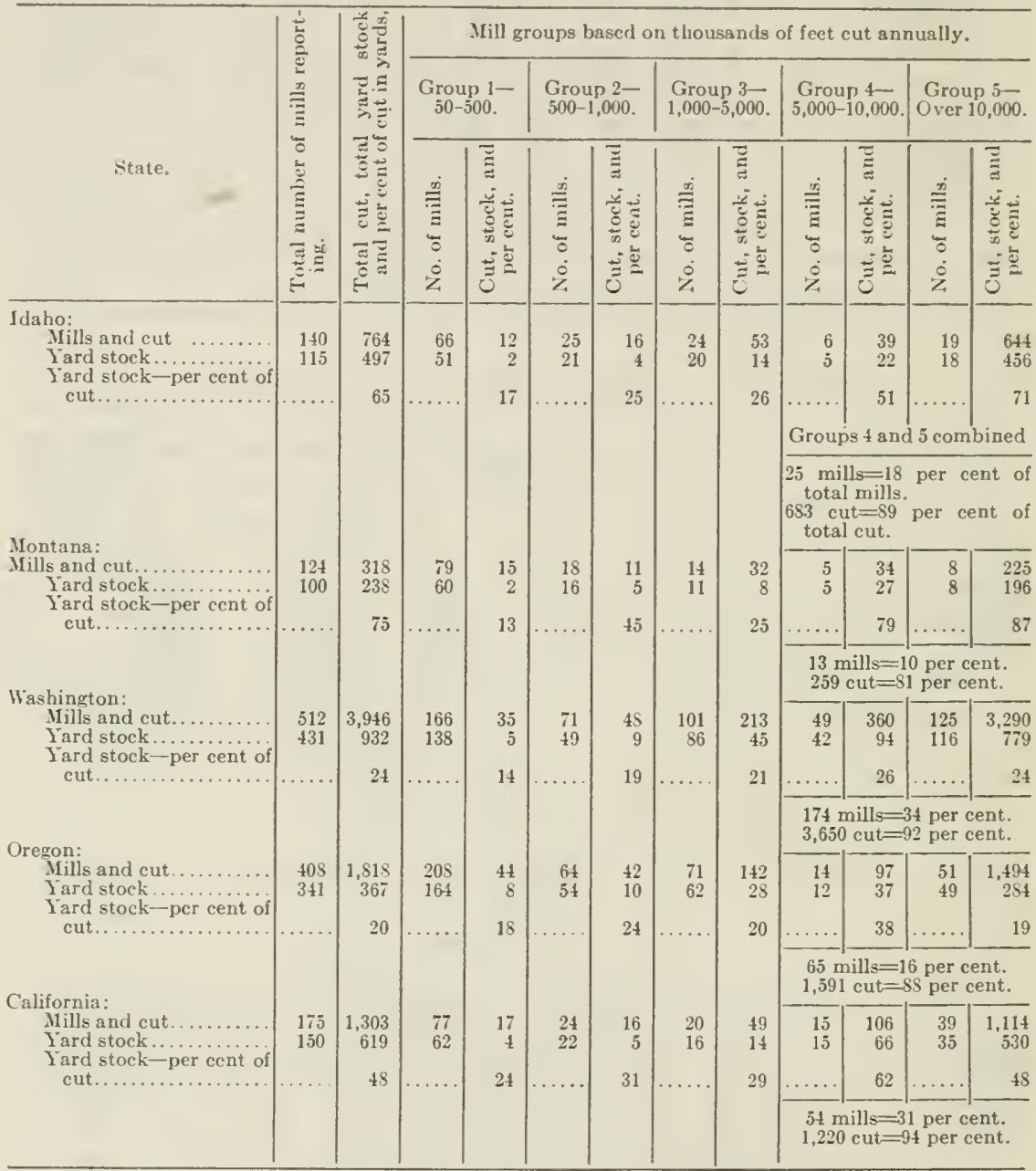

CUT BY MILLS OF TARIOT'S CLASSES IN 1913.

\begin{tabular}{|c|c|c|c|c|c|c|}
\hline Class............... & 1 & 2 & 3 & 4 & 5 & Total. \\
\hline $\begin{array}{l}\text { Idaho }{ }_{\text {Montana }} \quad \ldots \ldots \ldots \ldots \ldots \ldots \ldots \ldots \ldots \ldots \ldots \ldots \ldots \\
\text { M }\end{array}$ & $\begin{array}{l}18 \\
13\end{array}$ & 12 & $\begin{array}{l}39 \\
26\end{array}$ & $\begin{array}{l}33 \\
49\end{array}$ & $\begin{array}{l}549 \\
266\end{array}$ & $\begin{array}{l}651 \\
315\end{array}$ \\
\hline
\end{tabular}

Nore.-Class 4 and 5 mills cut $\$ 9$ per cent of the total output in Idaho and $\$ 8$ per cent in Jrontana. 
TABLE 26.-Classes of mills by regions in 1914.-From the U. S. Census.

\begin{tabular}{|c|c|c|c|c|c|c|}
\hline \multirow{2}{*}{ Annual cut of mill. } & \multicolumn{6}{|c|}{ Mill cut in thousands of board feet per year. } \\
\hline & $\begin{array}{c}1 \\
50 \mathrm{M} \text { to } \\
500 \mathrm{MI}\end{array}$ & $\begin{array}{c}2 \\
500 \mathrm{M} \text { to } \\
1,000 \mathrm{M} .\end{array}$ & $\begin{array}{c}3 \\
1,000 \mathrm{M} \text { to } \\
5,000 \mathrm{M} \text {. }\end{array}$ & $\begin{array}{c}4 \\
5,000 \mathrm{MI} \text { to } \\
10,000 \mathrm{MI}\end{array}$ & $\begin{array}{c}5 \\
\text { Over } \\
10,000 \mathrm{M}\end{array}$ & Total. \\
\hline 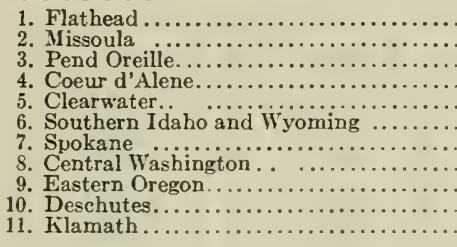 & $\begin{array}{r}9 \\
21 \\
2 \\
5 \\
21 \\
50 \\
39 \\
43 \\
42 \\
23 \\
8\end{array}$ & $\begin{array}{r}7 \\
8 \\
1 \\
3 \\
12 \\
7 \\
15 \\
16 \\
13 \\
6 \\
2\end{array}$ & $\begin{array}{r}6 \\
7 \\
3 \\
3 \\
9 \\
9 \\
13 \\
16 \\
11 \\
1 \\
6\end{array}$ & $\begin{array}{l}4 \\
3 \\
1 \\
5 \\
\cdots \\
3 \\
1 \\
1 \\
5 \\
1 \\
1\end{array}$ & $\begin{array}{r}2 \\
4 \\
4 \\
12 \\
3 \\
7 \\
7 \\
2 \\
5 \\
2 \\
2\end{array}$ & $\begin{array}{l}28 \\
40 \\
11 \\
28 \\
45 \\
66 \\
77 \\
78 \\
76 \\
31 \\
19\end{array}$ \\
\hline Total... & 263 & 90 & 84 & 21 & 41 & 499 \\
\hline Total for $1912 \ldots \ldots \ldots \ldots \ldots$ & 296 & 111 & 101 & 15 & 39 & 562 \\
\hline Change from 1912 to 1914 , plus or minus.... & -33 & -21 & -17 & +6 & +2 & -63 \\
\hline
\end{tabular}

TABLE 27.-Average number of ten-hour shifts operated per year in mills of different sizes in 1912.

\begin{tabular}{|c|c|c|c|c|c|}
\hline \multirow{4}{*}{ State. } & \multicolumn{5}{|c|}{ Mill cut in thousands of board feet per year. } \\
\hline & \multicolumn{5}{|c|}{ Size of mill. } \\
\hline & $\begin{array}{l}50 \text { to } \\
500 \text {. }\end{array}$ & $\begin{array}{l}500 \text { to } \\
1,000 \text {. }\end{array}$ & $\begin{array}{l}1,000 \text { to } \\
5,000 \text {. }\end{array}$ & $\begin{array}{l}5,000 \text { to } \\
10,000 \text {. }\end{array}$ & $\begin{array}{c}10,000 \\
\text { and over. }\end{array}$ \\
\hline & \multicolumn{5}{|c|}{ Number of 10 -hour shifts operated. } \\
\hline 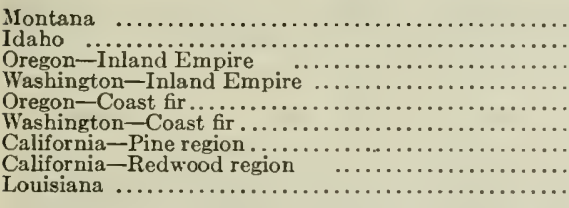 & $\begin{array}{r}36 \\
47 \\
52 \\
41 \\
63 \\
111 \\
57 \\
96 \\
67\end{array}$ & $\begin{array}{r}72 \\
83 \\
77 \\
75 \\
123 \\
139 \\
113 \\
187 \\
116\end{array}$ & $\begin{array}{l}128 \\
128 \\
104 \\
130 \\
146 \\
142 \\
120 \\
157 \\
156\end{array}$ & $\begin{array}{l}162 \\
173 \\
206 \\
191 \\
210 \\
221 \\
149 \\
199 \\
205\end{array}$ & $\begin{array}{l}196 \\
243 \\
272 \\
223 \\
232 \\
267 \\
186 \\
271 \\
283\end{array}$ \\
\hline
\end{tabular}

TABLE 28.-Inland Empire mill inventories.

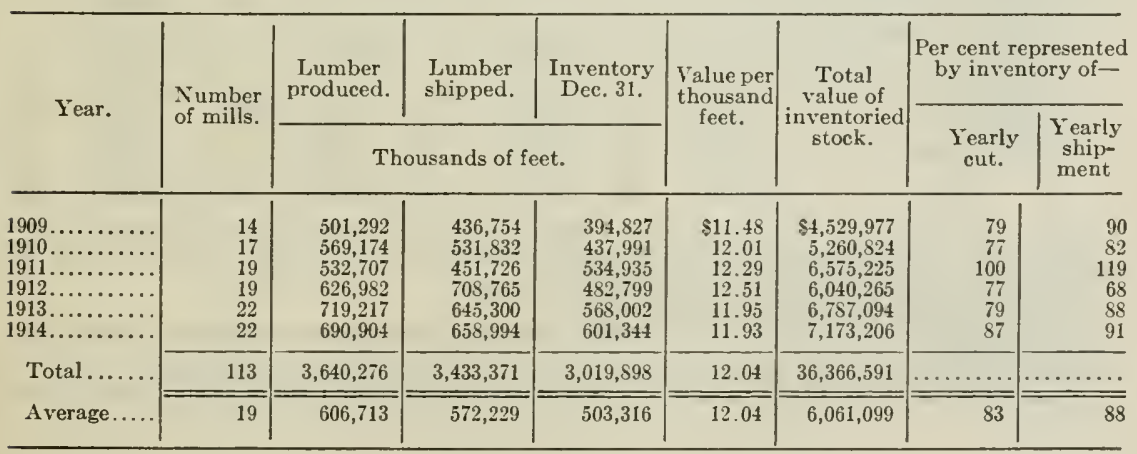


TABLE 29.-Distribution of lumber shipments from the Inland Empire. Computed from reports of the Montana Larch and Pine Association and the Western Pine Manufacturers'Association.

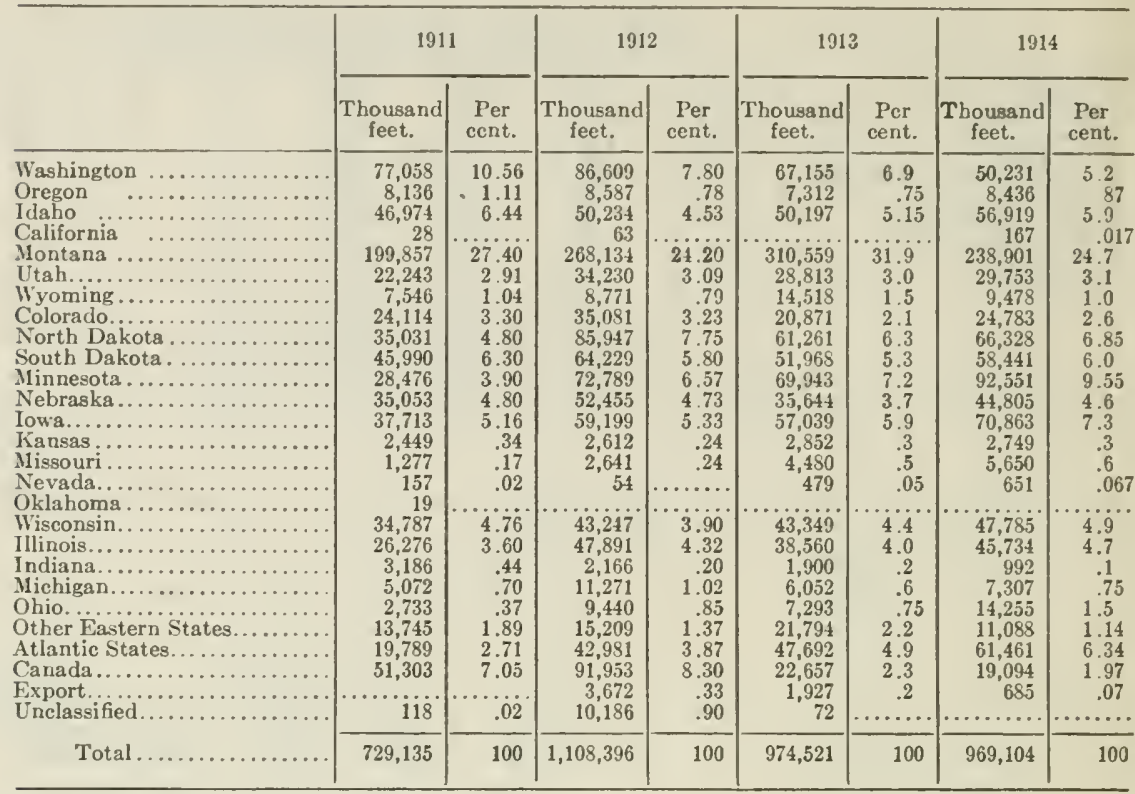

TABLE 29A.-Comparative shipments of Inland Empire lumber to various regions, based on shipments reported by the Western Pine Manufacturers' Association for 1911, 1914, 1917 and 1919.

\begin{tabular}{|c|c|c|c|c|c|c|c|c|c|}
\hline \multirow{2}{*}{ Group. } & \multirow{2}{*}{ Region. } & \multicolumn{2}{|c|}{1911} & \multicolumn{2}{|c|}{1914} & \multicolumn{2}{|c|}{1917} & \multicolumn{2}{|c|}{1919} \\
\hline & & $\begin{array}{c}\text { Thousand } \\
\text { board } \\
\text { feet. }\end{array}$ & $\begin{array}{c}\text { Per } \\
\text { cent of } \\
\text { total. }\end{array}$ & $\begin{array}{c}\text { Thousand } \\
\text { board } \\
\text { feet. }\end{array}$ & $\begin{array}{l}\text { Per } \\
\text { cent of } \\
\text { total. }\end{array}$ & $\begin{array}{c}\text { Thousand } \\
\text { board } \\
\text { feet. }\end{array}$ & $\begin{array}{l}\text { Per } \\
\text { cent of } \\
\text { total. }\end{array}$ & $\begin{array}{c}\text { Thousand } \\
\text { board } \\
\text { feet. }\end{array}$ & $\begin{array}{l}\text { Per } \\
\text { cent of } \\
\text { total. }\end{array}$ \\
\hline $\begin{array}{l}1 \\
2\end{array}$ & $\begin{array}{l}\text { Inland Empire........ } \\
\text { Rocky Mountain states }\end{array}$ & 332,025 & 45.5 & 354,487 & 36.6 & 70,474 & 12.6 & 79,868 & 8.4 \\
\hline 3 & $\begin{array}{l}\text { outside Inland Em- } \\
\text { pire } \ldots \ldots \ldots \ldots \ldots\end{array}$ & 53,903 & 7.4 & 64,014 & 6.6 & 57,588 & 10.3 & 68,846 & 7.2 \\
\hline & of river................. & 186,008 & 25.5 & 341,387 & 35.2 & 246,061 & 43.9 & 425,402 & 44.7 \\
\hline 4 & $\begin{array}{r}\text { Mivsiver................ } \\
\text { of river }\end{array}$ & 72,054 & 9.9 & 116,073 & 12.0 & 112,216 & 20.3 & 227,090 & 23.9 \\
\hline 5 & Atlantic Coast......... & 33,534 & 4.6 & 72,549 & 7.5 & 65,385 & 11.7 & 145,407 & 15.3 \\
\hline $\begin{array}{l}6 \\
7\end{array}$ & $\begin{array}{l}\text { Foreign ......... } \\
\text { Not specified... }\end{array}$ & $\begin{array}{r}51,303 \\
185\end{array}$ & $\begin{array}{r}7.07 \\
.03\end{array}$ & $\begin{array}{r}19,779 \\
818\end{array}$ & $\begin{array}{r}2.0 \\
.1\end{array}$ & $\begin{array}{r}5,818 \\
889\end{array}$ & $\begin{array}{r}1.0 \\
.2\end{array}$ & $\begin{array}{r}50 \\
5,113\end{array}$ & $\begin{array}{l}.0 \\
.5\end{array}$ \\
\hline & Total & 729,012 & 100 & 969,107 & 100 & 558,431 & 100 & 951,776 & 100 \\
\hline
\end{tabular}

Note.-The years 1911 and 1914 include all specics shipped; the years 1917 and 1919 include only the white pine, western pine, Douglas fir and larch shipped.

Group 1 includes Idaho, Montana, Washington and Oregon.

Group 2 includes Colorado, Wyoming, and Utah.

Group 3 includes North Dakota, South Dakota, Minnesota, Iowa, Kansas, Nebraska, Missouri, Oklahoma and Arkansas.

Group 4 includes Wisconsin, Michigan, Illinois, Indiana, Ohio, West Virginia and Kentucky.

Group 5 includes Pennsylvania, Delaware, New York, New Jersey, Maryland, District of Columbia and New England. 
TABLE 30--Average mill values of lumber and freight thereon to each State consuming Inland Empire products, based on partial shipments by members of the Lumbermen's Information Bureau, Spokane. 1913.

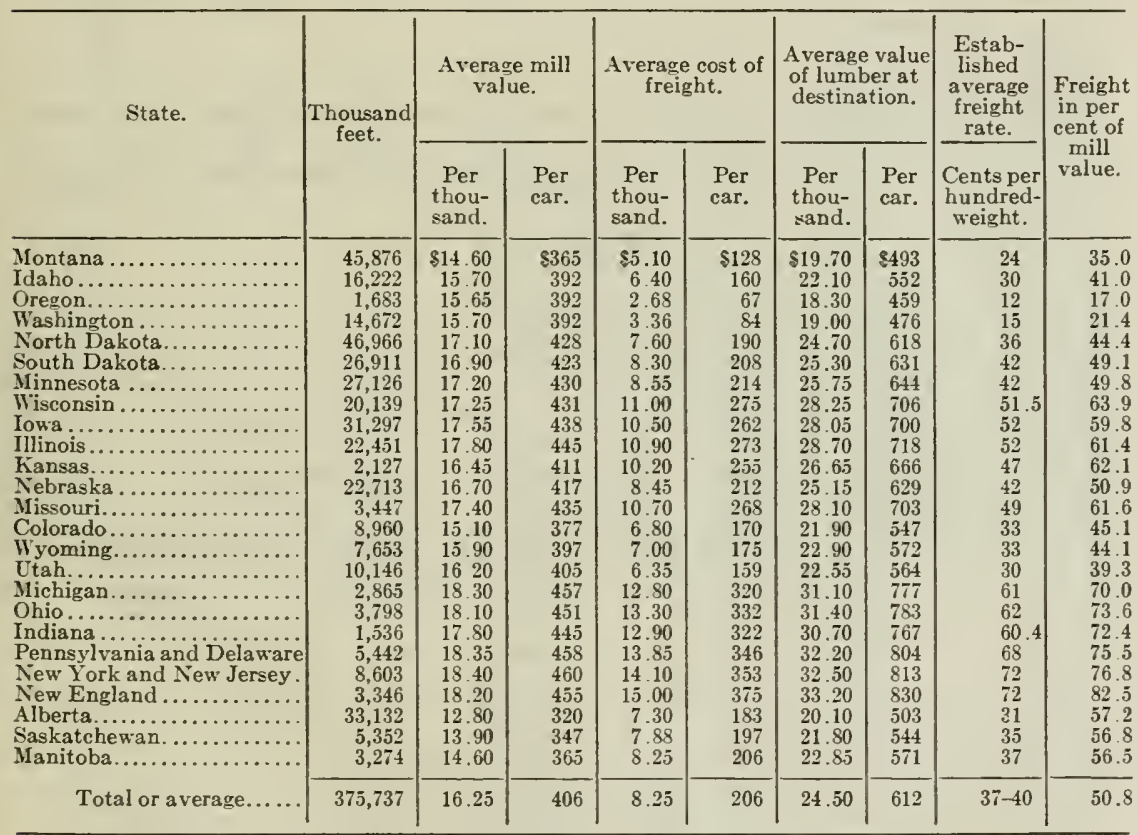




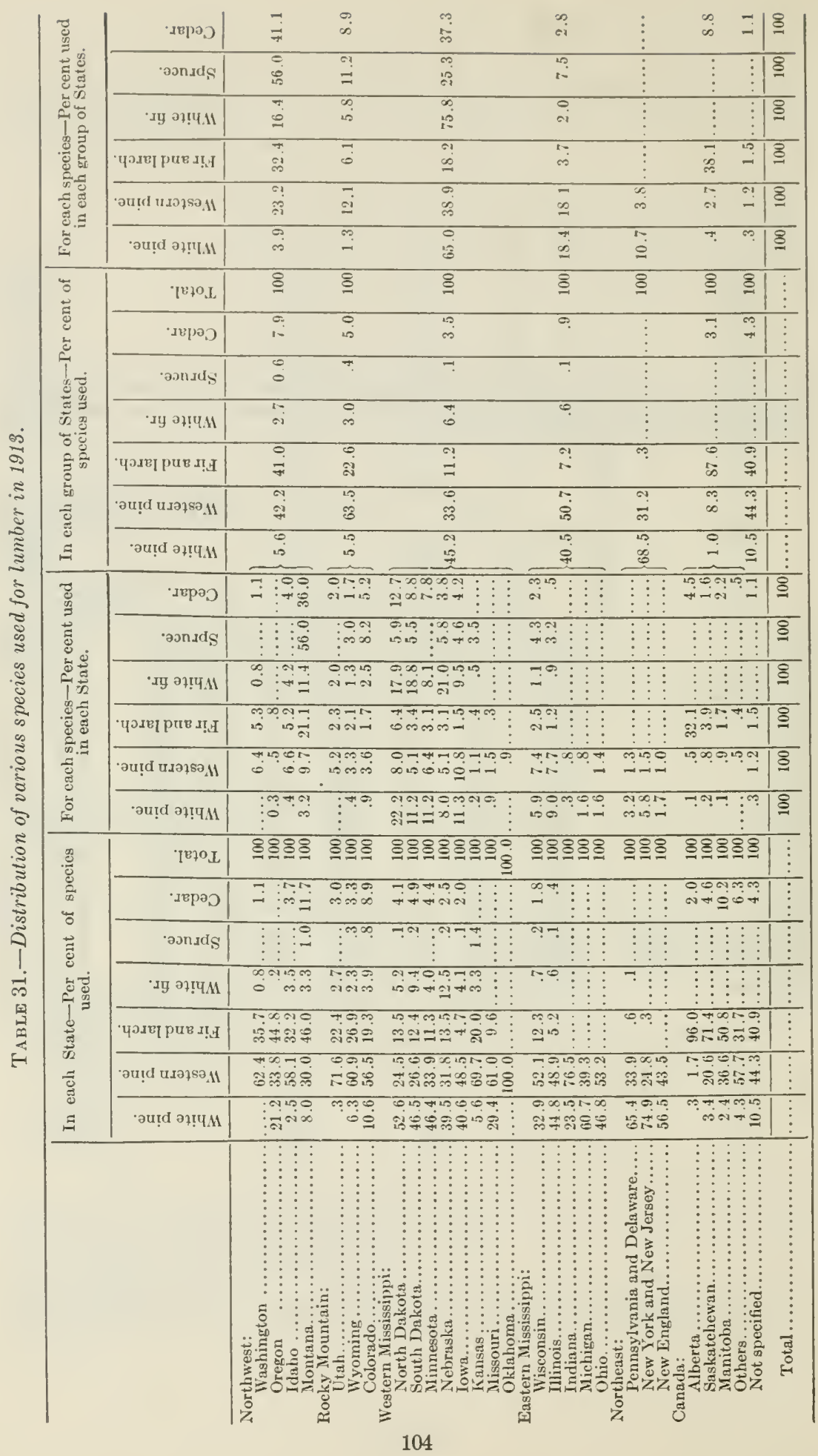


TABLE 32.-Number of men employed in the lumber industry in the Inland Empire in 1909. Seasonal character of employment indicated.

\begin{tabular}{|c|c|c|c|c|c|c|}
\hline & \multicolumn{3}{|c|}{ Idaho. } & \multicolumn{3}{|c|}{ Montana. } \\
\hline & Total. & Woods. & Mills. & Total. & Woods. & Mills. \\
\hline 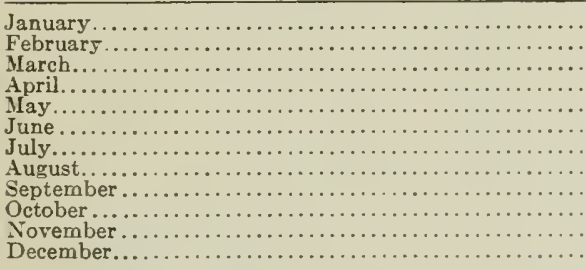 & $\begin{array}{l}3,333 \\
3,430 \\
4,486 \\
5,230 \\
5,624 \\
5,716 \\
5,553 \\
5,400 \\
5,361 \\
5,820 \\
5,377 \\
5,226\end{array}$ & $\begin{array}{l}1,890 \\
1,796 \\
2,123 \\
2,032 \\
1,959 \\
2,028 \\
1,956 \\
1,891 \\
2,076 \\
2,369 \\
2,509 \\
2,653\end{array}$ & $\begin{array}{l}1,443 \\
1,634 \\
2,363 \\
3,198 \\
3,665 \\
3,699 \\
3,597 \\
3,509 \\
3,285 \\
3,451 \\
2,869 \\
2,573\end{array}$ & $\begin{array}{l}2,838 \\
2,777 \\
2,663 \\
2,589 \\
2,858 \\
2,795 \\
2,709 \\
3,108 \\
3,320 \\
3,673 \\
3,696 \\
3,276\end{array}$ & $\begin{array}{r}2,004 \\
1,834 \\
1,463 \\
732 \\
816 \\
870 \\
807 \\
1,149 \\
1,363 \\
1,685 \\
1,961 \\
2,011\end{array}$ & $\begin{array}{r}834 \\
943 \\
1,200 \\
1,857 \\
2,072 \\
1,925 \\
1,902 \\
1,959 \\
1,957 \\
1,989 \\
1,735 \\
1,265\end{array}$ \\
\hline
\end{tabular}




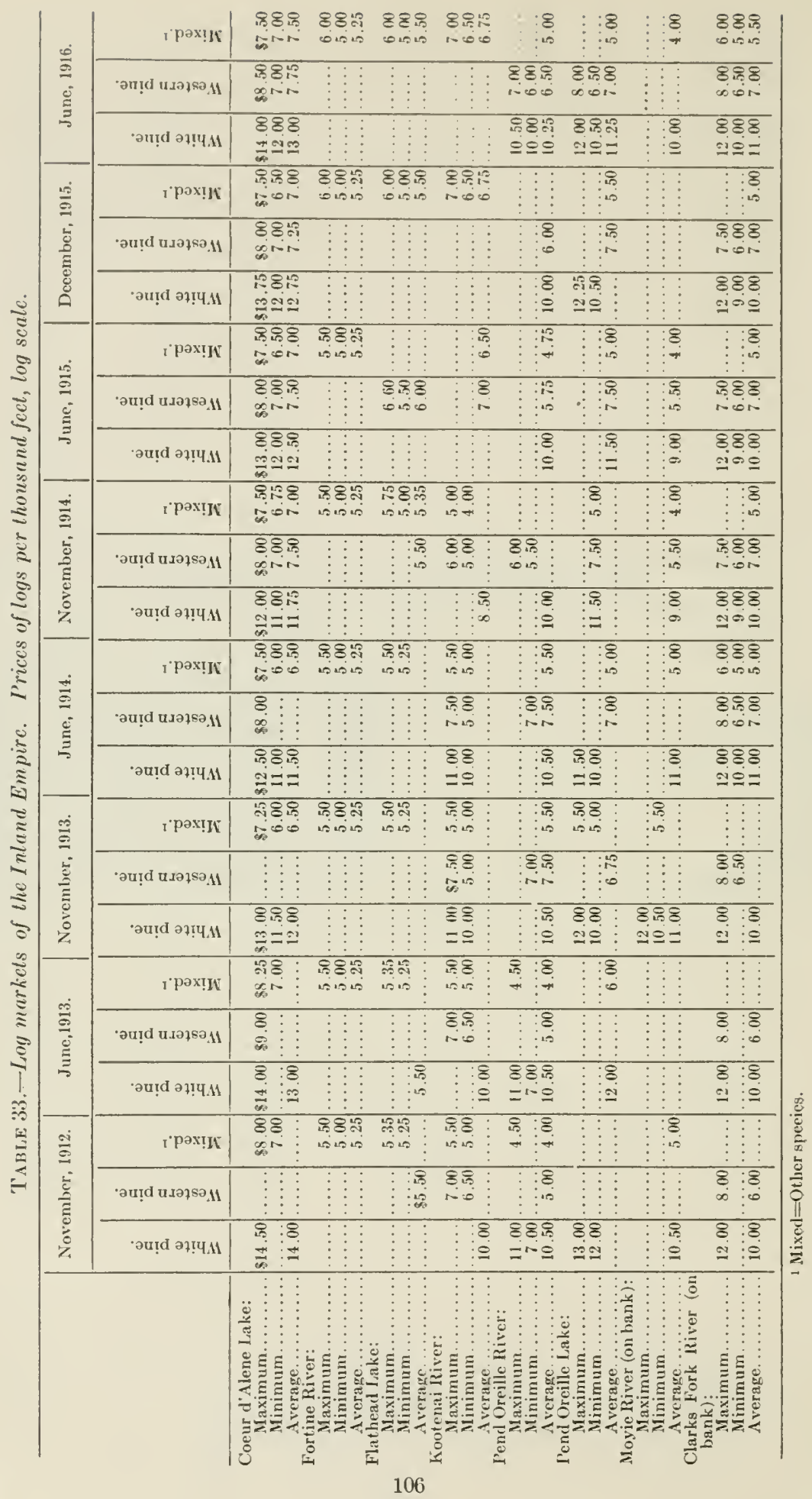


FIGURE /3

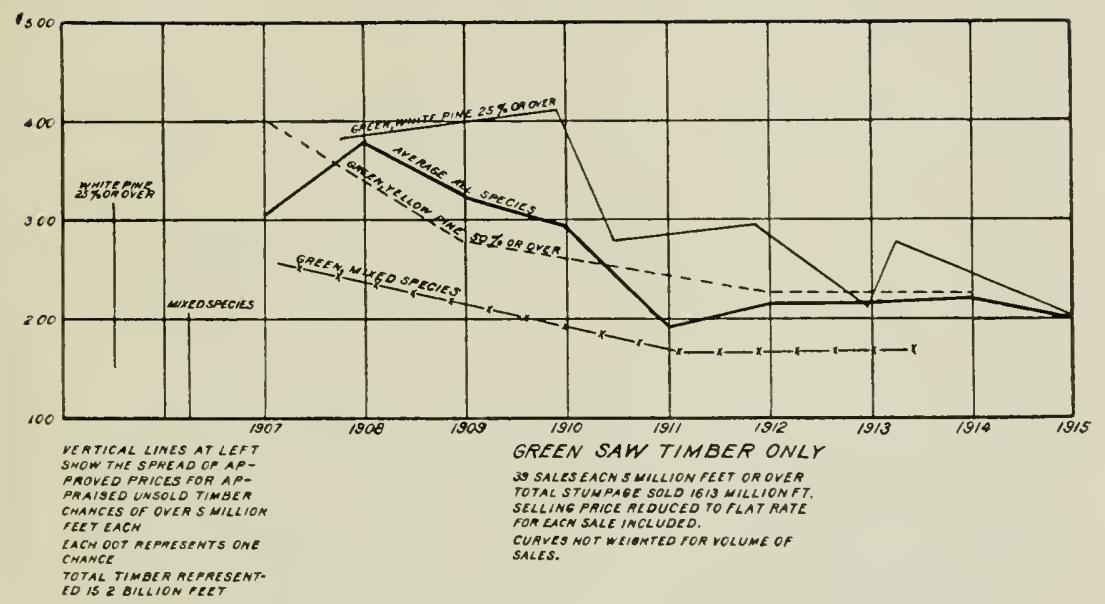

INLANO EMPIRE STUMPAGE PRICES - ON NATIONAL FORESTS. 
FIGURE 14

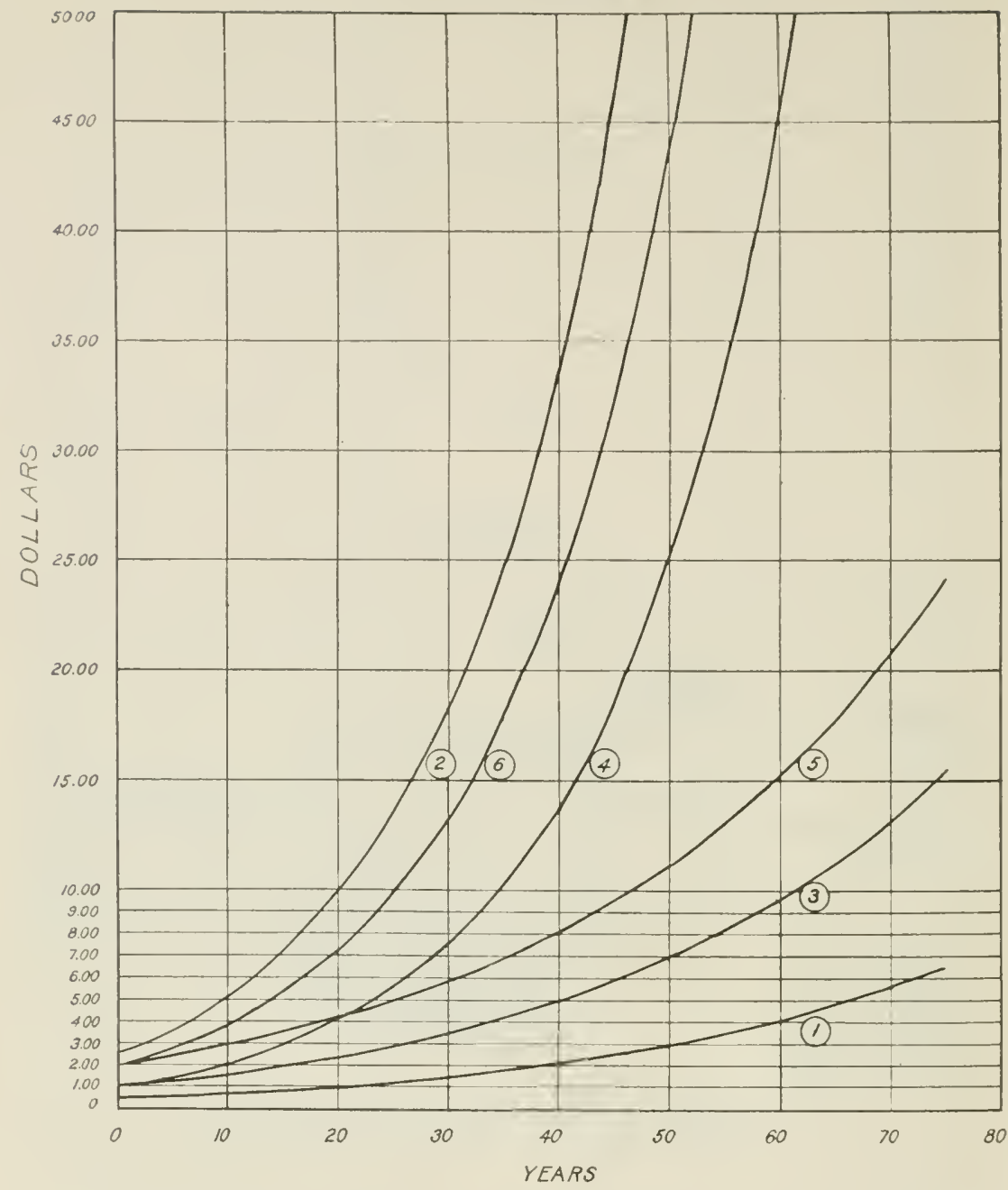

ILLUSTRATING "COST"OF CARRYING STUMPAGE UNDER DIFFERENT CONDITIONS IF COMPOUND INTEREST IS INCLUDED

ANNUAL EXPENSE FOR:

\begin{tabular}{|c|c|c|c|c|}
\hline $\begin{array}{c}\text { Curve } \\
\text { No }\end{array}$ & $\begin{array}{c}\text { Original Owtby } \\
\text { For Stumpage }\end{array}$ & Taxes & $\begin{array}{c}\text { Protection and } \\
\text { Administration }\end{array}$ & $\begin{array}{c}\text { Compound interest } \\
\text { Rate Percent }\end{array}$ \\
\hline 1 & 1.50 & $\$ 005$ & $\$ .002$ & 3 \\
\hline 2 & 2.50 & 040 & .010 & 6 \\
\hline 3 & 1.00 & .015 & .006 & 3 \\
\hline 4 & 100 & .015 & .006 & 6 \\
\hline 5 & 2.00 & .020 & .002 & 3 \\
\hline 6 & 200 & .020 & .002 & 6 \\
\hline
\end{tabular}


FIGURE 15

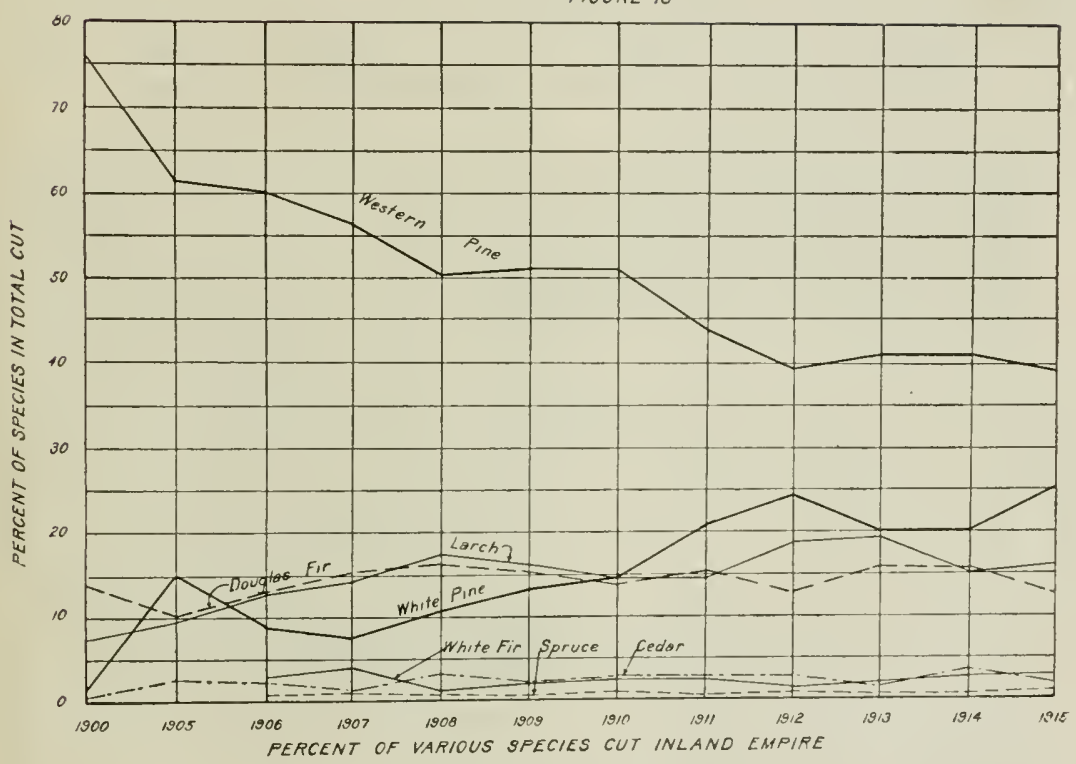




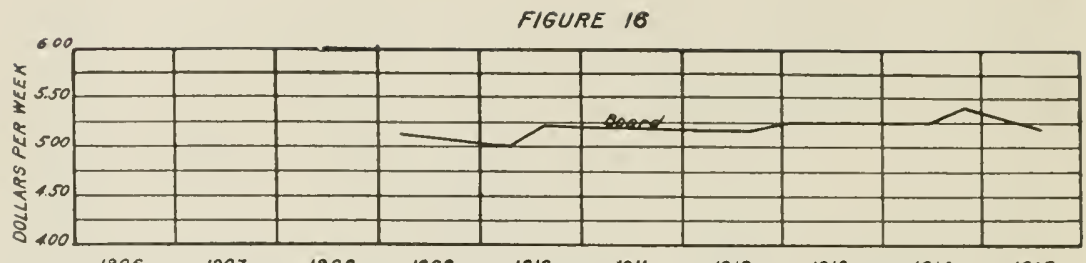

$\begin{array}{llllllllll}1906 & 1907 & 1908 & 1909 & 1910 & 1911 & 1912 & 1913 & 1914 & 1915\end{array}$ FLUCTUATION IN CHARGE FOR BOARD AT INLAND EMPIRE LOGGING CAMPS

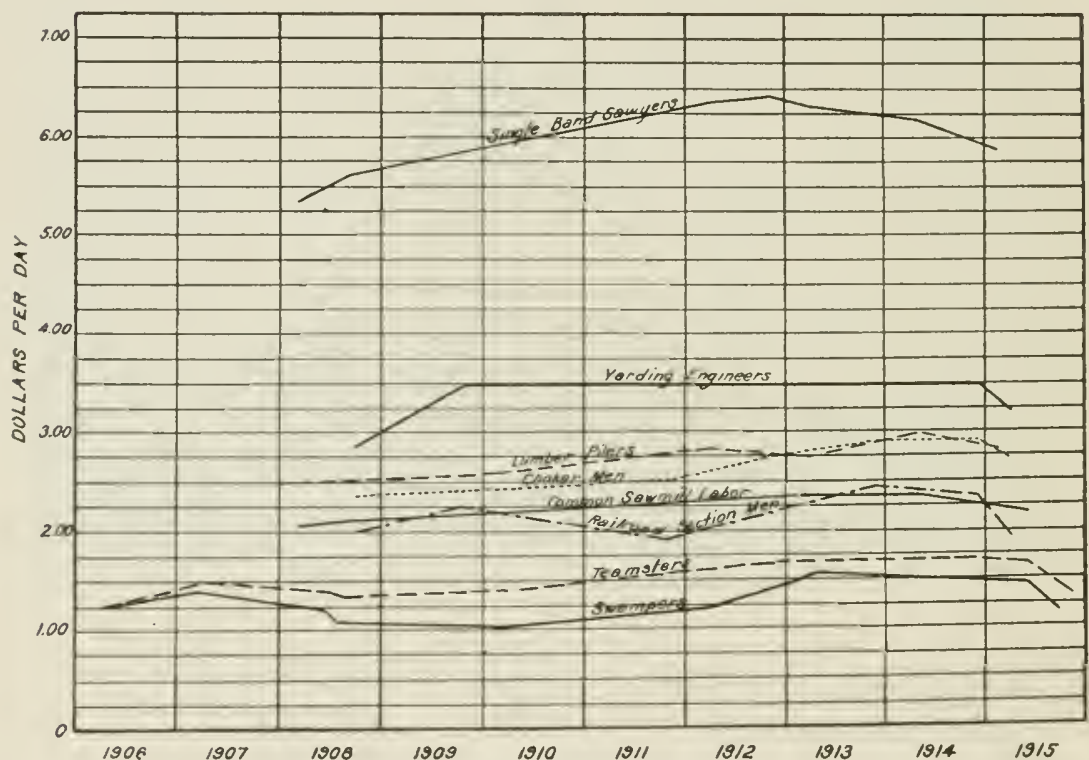

FLUCTUATION IN WAGES FOR CERTAIN OCCUPATIONS AT INLAND EMPIRE LOGGING CAMPS ANO SAWMILLS 


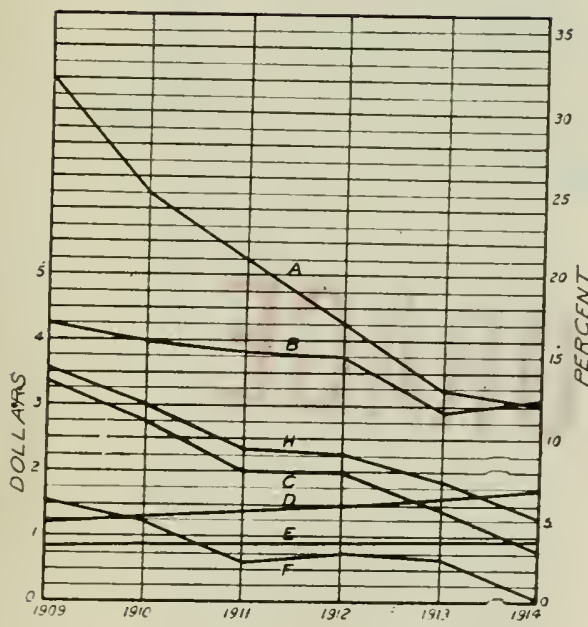

A Percent profit (compound interest) on stumpage
(Stumpage at book value) 8 Book value of stumpage

6 Percent earnings (simple imteresti on operatin capital (Stumpage at cost plus 6: Cmpo int) - Stumpage cost plus 67

Sturmpage cost actual outlay without interest $E$ Percent earnings (simpleintereston operotes capital Stumpage at book value

Percent earnings rsumple interestlon opergting capital (Stumpage af cost without interest ing

uे

FIGURE |7

RELATION OF PROATS

STUMPAGE , OPERATION 


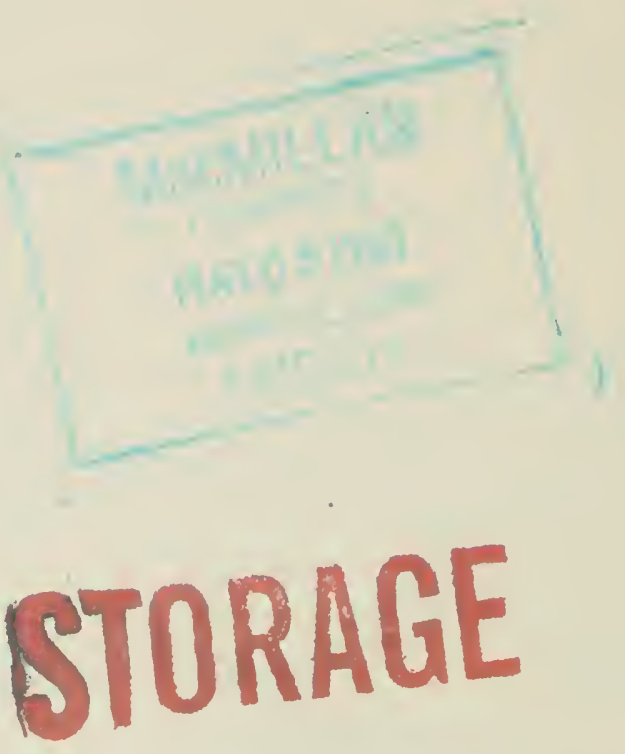




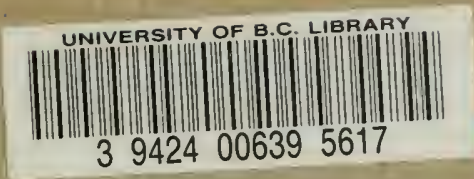

\section{MacMILLAN LIBRARY}

\section{STORAGE}

University of British Columbia Library DUE DATE

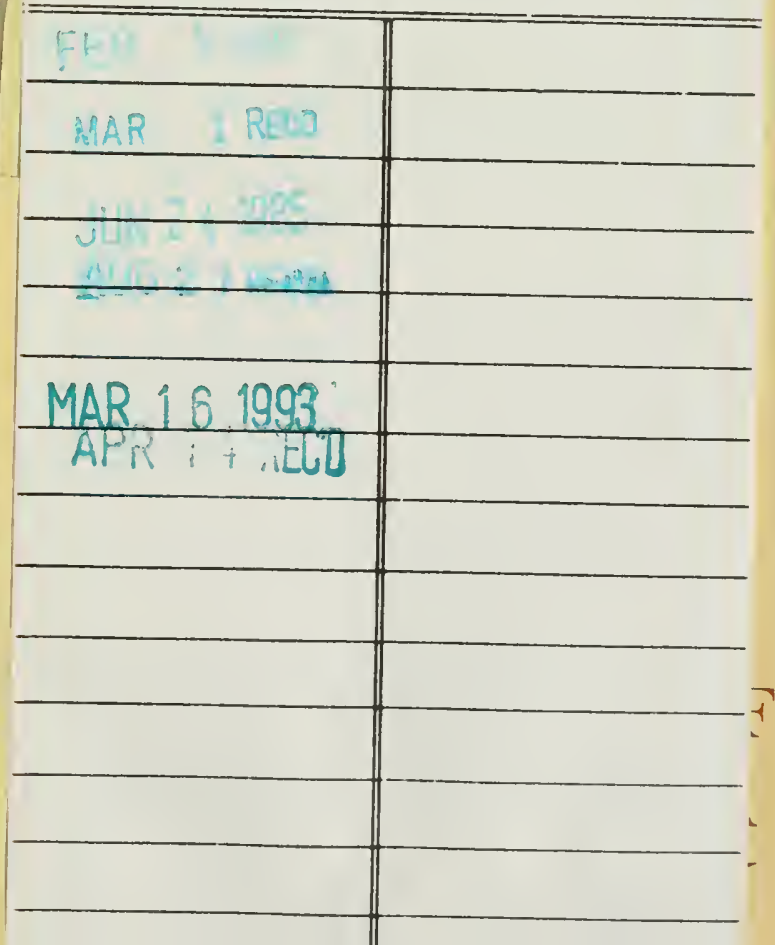


Plowe

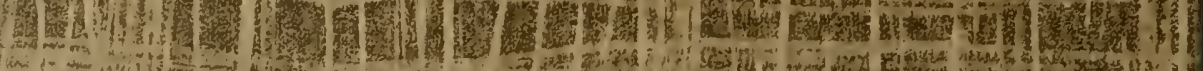
ต1

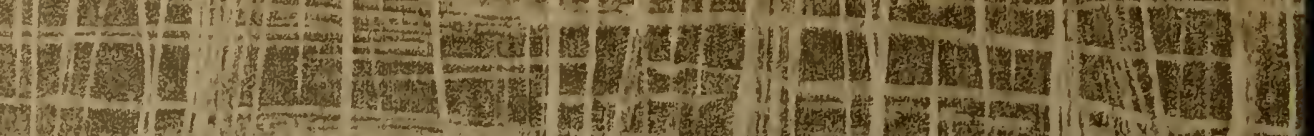

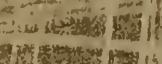

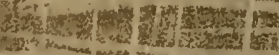

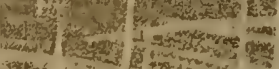
con the

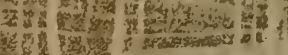

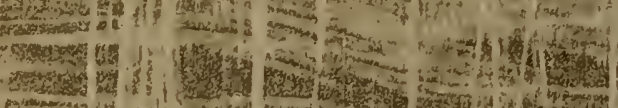
rovk

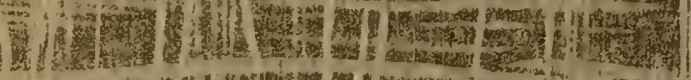
If

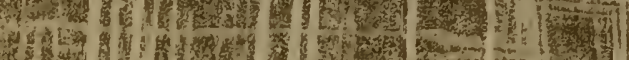

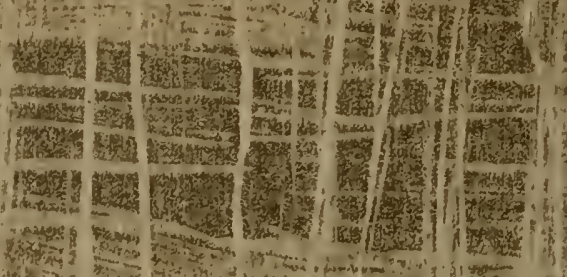

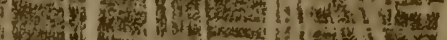

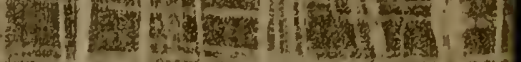

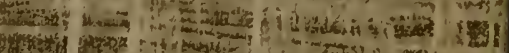
(1) 4.

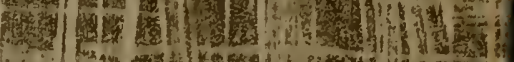

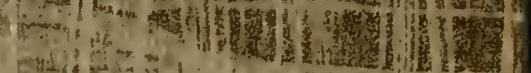
絖i

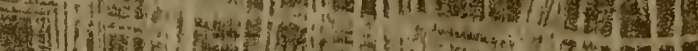

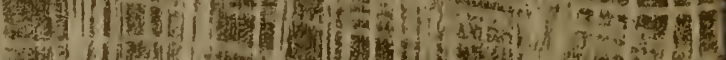
wor

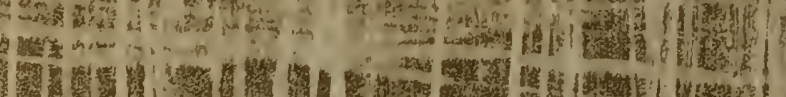

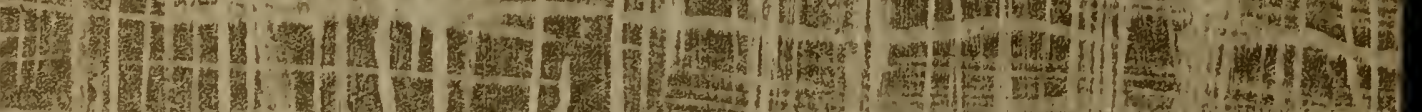

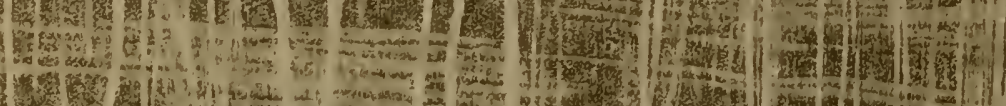

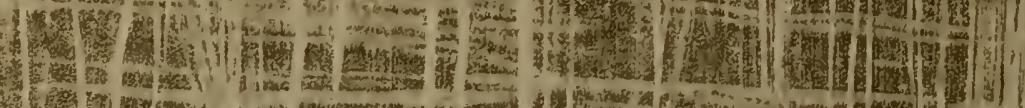

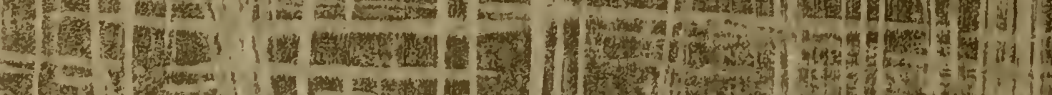

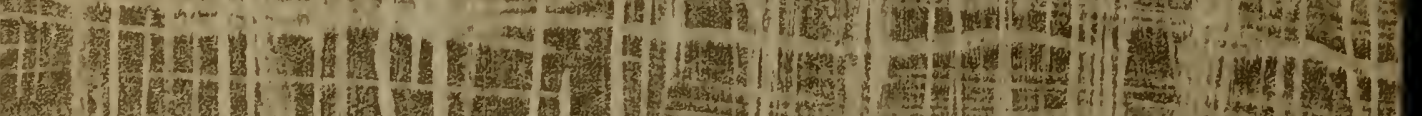

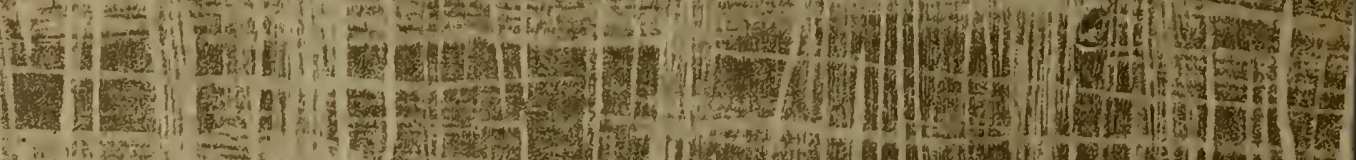

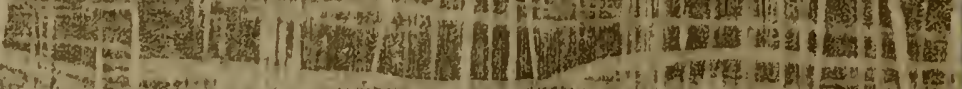
I 군

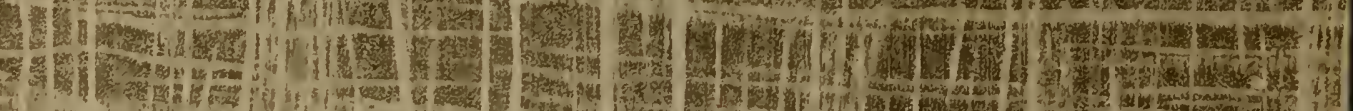

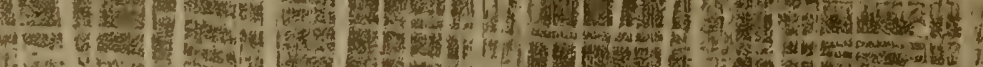

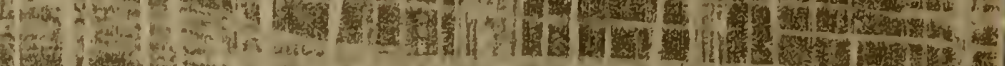
f. 1 for P留

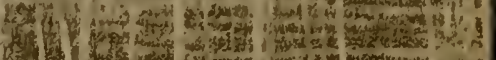
1. W 1 ir 10을

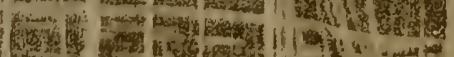

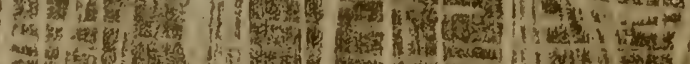

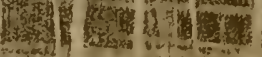

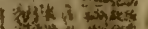
Toxis

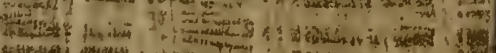
inend for 